\title{
Description, redescription and revision of sixteen putatively closely related species of Echinoderes (Kinorhyncha: Cyclorhagida), with the proposition of a new species group - the Echinoderes dujardinii group
}

\section{Martin V. SØRENSEN ${ }^{1, *}$, Freya E. GOETZ ${ }^{2}$, María HERRANZ ${ }^{3}$, Cheon Young CHANG $^{4}$, Tapas CHATTERJEE ${ }^{5}$, Furkan DURUCAN ${ }^{6}$, Ricardo C. NEVES ${ }^{7}$, N. Özlem YILDIZ ${ }^{8}$, Jon NORENBURG ${ }^{9}$ \& Hiroshi YAMASAKI ${ }^{10}$}

${ }^{1,3}$ Natural History Museum of Denmark, University of Copenhagen, DK-2100 Copenhagen, Denmark.

${ }^{2,9}$ Department of Invertebrate Zoology, Smithsonian National Museum of Natural History, Washington, DC 20560, USA.

${ }^{4}$ Department of Biological Science, College of Natural and Life Sciences, Daegu University, Gyeongsan 38453, Korea.

${ }^{5}$ Crescent International School, Bario, Govindpur, Dhanbad 828109, Jharkhand, India. ${ }^{6}$ Isparta University of Applied Sciences, Department of Aquaculture, 32260 Isparta, Turkey.

${ }^{7}$ Department of Biology, University of Copenhagen, DK-2100 Copenhagen, Denmark.

${ }^{8}$ Silifke Vocational School Aquaculture Program, Mersin University, 33940 Mersin, Turkey.

${ }^{10}$ Faculty of Arts and Science, Kyushu University, Fukuoka 819-0395, Japan.

"Corresponding author: mvsorensen@snm.ku.dk

${ }^{2}$ Email: GoetzF@si.edu

${ }^{3}$ Email: maria.herranz@bio.ku.dk

4Email: cychang@daegu.ac.kr

${ }^{5}$ Email: drtchatterjee@gmail.com

${ }^{6}$ Email: f durucan@hotmail.com

${ }^{7}$ Email: ricardon.6@gmail.com

${ }^{8}$ Email: nozlemkoroglu@gmail.com

${ }^{9}$ Email: NORENBUR@si.edu

${ }^{10}$ Email: h.yamasaki@meiobenthos.com

\footnotetext{
${ }^{1}$ urn:1sid:zoobank.org:author:4143D650-12FC-4914-93F5-2C39339A7156

${ }^{2}$ urn:lsid:zoobank.org:author:5849A537-F762-4B25-9493-E8B32690C49D

${ }^{3}$ urn:1sid:zoobank.org:author:2A7DE5DC-FF82-49CC-9DD4-CC0AFA1B281B

${ }^{4}$ urn:lsid:zoobank.org:author:497A5735-AA95-498A-A1B8-58180C2ACA33

${ }^{5}$ urn:lsid:zoobank.org:author:F35C0625-55F6-4307-A7BE-93416BE6F0D7

${ }^{6}$ urn:Isid:zoobank.org:author:62189A90-E675-49B1-BE3C-F4657CA40EE4

${ }^{7}$ urn:Isid:zoobank.org:author:C2B164FF-E8D8-468E-A07E-C39E1C71E65E

${ }^{8}$ urn:lsid:zoobank.org:author:CE2E097A-4499-498C-980E-F21A4156F76E

${ }^{9}$ urn:Isid:zoobank.org:author:B8710D9A-1549-4E17-AF4F-6B598744C02E

${ }^{10}$ urn:Isid:zoobank.org:author:DE5B433D-D203-4EF9-8D25-0D0608477A19
} 
Abstract. Thirteen species of Echinoderes with nearly identical spine/tube patterns, and apparently similar tergal extensions were re-examined and compared. Based on this, redescriptions and/or emended species diagnoses are provided for Echinoderes aureus, E. dujardinii, E. gerardi, E. imperforatus, E. pacificus, E. pilosus, E. sensibilis, E. sublicarum and E. worthingi, and new details about cuticular structures are added for E. kozloffi and E. gizoensis. The new information derived from the redescriptions, and the subsequent comparative studies revealed that: 1) the holotype of Echinoderes lanceolatus is identical with the types of Echinoderes aureus, and E. lanceolatus is thus a junior synonym of E. aureus; other potentially synonymous species that should be addressed further in the future include: $E$. dujardinii + E. gerardi; E. imperforatus + E. sensibilis, and E. pacificus + E. sublicarum; 2) the paratypes of E. lanceolatus represented a different yet undescribed species, here described as E. songae Sørensen \& Chang sp. nov.; 3) a comparison with literature information about $E$. ehlersi showed that the species is so insufficiently described that a redescription of topotype material is required before the species should be considered for taxonomic comparison; 4) specimens from the Andaman Islands, India, that previously have been reported as Echinoderes cf. ehlersi represent two different undescribed species, of which one is described as E. chandrasekharai Sørensen \& Chatterjee sp. nov. and the other is left undescribed due to the limited material available; 5) out of a total of fifteen addressed species, it is proposed that eleven represent a putatively monophyletic group that is named the Echinoderes dujardinii group. The group includes following species: E. dujardinii, E. ehlersi, E. gerardi, E. imperforatus, E. kozloffi, E. sensibilis, E. pacificus, E. sublicarum, E. songae Sørensen \& Chang sp. nov., E. chandrasekharai Sørensen \& Chatterjee sp. nov., and Echinoderes sp. from the Andaman Islands, and is supported by a similar spine/tube pattern (except for variation regarding the presence of lateral accessory tubes on segment 8); generally short middorsal spines, especially on segments 4 to 6; glandular cell outlets type 1 always present in middorsal positions on segments 1 to 3 , and in subdorsal positions on segments 4 to 9; glandular cell outlets type 2 always present in laterodorsal or midlateral positions on segment 8 , and sometimes in same positions on segment 9 but never at any other segments or positions; female papillae always present on sternal plates of segments 7 and 8 , and occasionally also on segment 6 ; tergal extensions well-spaced, triangular, gradually tapered cones, and pectinate fringes of sternal extensions are differentiated into seta-like tufts. The comparisons furthermore showed potential taxonomic significance of two echinoderid character traits that previously have been slightly neglected as diagnostic traits, namely the presence and appearance of female papillae, and the dorsal pattern of glandular cell outlets type 1. Female papillae may occur on the sternal plates of segments 6 to 8 , but the positions may differ from ventrolateral to ventromedial, and the morphology of the intracuticular substructure also differ at species level. Information about position and morphology of female papillae proved helpful for species recognition, but it might also provide information of phylogenetic importance. Analyses of glandular cell outlet type 1 patterns on the dorsal sides of segments 1 to 9 in species of Echinoderidae, revealed several apparently unique or rare patterns, but also three distinct patterns that applied to larger groups of species. One pattern is the one present in all species of the E. dujardinii group, whereas the other two common patterns included 1) middorsal outlets on segments 1 to 3 , and paradorsal outlets on segments 4 to 9 (found in 27 species), and 2) middorsal outlets on segments 1 to 3,5 and 7, and paradorsal outlets on segments 4, 6 and 8 to 9 (found in 27 species).

Keywords. Echinoderidae, kinorhynchs, meiofauna, taxonomy.

Sørensen M.V., Goetz F.E., Herranz M., Chang C.Y., Chatterjee T., Durucan F., Neves R.C., Yildiz N.Ö., Norenburg J. \& Yamasaki H. 2020. Description, redescription and revision of sixteen putatively closely related species of Echinoderes (Kinorhyncha: Cyclorhagida), with the proposition of a new species group - the Echinoderes dujardinii group. European Journal of Taxonomy 730: 1-101. https://doi.org/10.5852/ejt.2020.730.1197 


\section{Introduction}

The present study took its start during a zoological marine biology workshop, arranged by the Smithsonian Institution, on the Hawai'i Institute of Marine Biology at Coconut Island, Kaneohe Bay, Hawaii in May, 2017. Samples taken from rich organic mud in a small lagoon at the marine station, revealed an abundant fauna of echinoderid kinorhynchs, with a conspicuous brown-red colouring. This unusual colouring, combined with the remote locality far away from regions with a better-explored kinorhynch fauna, made us expect that this was a new species, that could be described in a short, taxonomic contribution. However, reality turned out to be way more complicated, and three years of intensive work and 64 manuscript pages later, we could conclude that the Hawaiian species was Echinoderes sensibilis Adrianov et al., 2002 - a species that so far was known from Japan only (Adrianov et al. 2002b; Yamasaki et al. 2014; Yamasaki 2017). The path to this conclusion went through the redescription of thirteen known species of Echinoderes, examination of so far unidentified species from museum collections, synonymization of two known species, and the description of two species new to science. This highlights the utmost importance of two cornerstones in taxonomy: 1) the need for detailed and accurate species descriptions that allow correct identification of collected animals, and 2) the need for access to type material in natural history museum collections.

The need for accurate and detailed taxonomic descriptions might sound obvious and trivial, but in a time where funding to taxonomic studies is cut to a minimum and where taxonomy is erroneously considered to be a secondary side product of ecological or metagenomic studies, good and solid taxonomic work is not something that can be taken for granted. Without taxonomy, organisms in ecological or metagenomic research would be nothing but numbers and nucleotide sequences.

But even taxonomic studies by experienced researchers will always be limited by the technological advances of the time when the study was done, and the included information and characters will always be a reflection of what was considered taxonomically important by the time it was done. This leads to the second corner stone - the availability of type material. Type material must at any time be made accessible for future researchers, in order to allow re-examination of the specimens. Such re-examinations can be extremely helpful to obtain a correct identification of newly collected species, but perhaps even more importantly, they allow taxonomists to update and improve existing species descriptions. Unfortunately, it is still not uncommon that type material is deposited in un-curated laboratory collections, or in repositories with loaning policies being so restrictive that the material is practically unavailable for the research community. The present study, that just started out with a species that needed to be identified, but concluded with a revision of an entire species group and the discovery of two new species, stresses the importance of high quality descriptions and access to type material.

By the beginning of the Smithsonian Workshop in Kaneohe Bay, the Hawaiian kinorhynch fauna had barely been explored, and only two identified species had been reported so far. One species is Echinoderes horni Higgins, 1983 that was collected near Honolulu and sequenced for the phylogenomic study of Dunn et al. (2008) (see Dunn et al. 2008: supplementary information). The second species is Cephalorhyncha liticola Sørensen, 2008 that was described from a narrow roadside beach, halfway between Laie and Punaluu at the Oahu east coast (Sørensen 2008). A re-visit to the type locality was attempted during the Smithsonian workshop, but only to realize that the beach no longer existed, and meanwhile had been replaced by boulders to protect the road from sea erosion. Hence, the species was never found again.

This summarizes the current information on Hawaiian kinorhynch fauna, and it is therefore our hope that the collected specimens from the Smithsonian workshop in 2017 can improve this knowledge considerably. Initial examinations of the collected material have revealed the existence of several 
different echinoderid species in the Kaneohe Bay area, and the present contribution is intended to be the first in a series that describes this fauna.

The species that initiated the present study was chosen due to its eye-catching colouration, and because it appeared to be the most abundant of the collected species. The initial microscopical examinations soon revealed that the specimens showed great resemblance with a group of very similar, but often insufficiently described echinoderid species. The species showed middorsal spines on segments 4 to 8 , tubes in lateroventral/ventrolateral positions on segment 2 and 5, lateroventral spines on segments 6 to 9 , laterodorsal/midlateral tubes on segment 10 , and long and slender lateral terminal spines. In addition, it had rather distinct, short well-spaced tergal extensions, with broad bases that would gradually taper into triangular tips. This spine/tube pattern combined with the characteristic tergal extensions can be observed in thirteen species of Echinoderes: Echinoderes aureus Adrianov et al., 2002, E. dujardinii Claparède, 1863, E. ehlersi Zelinka, 1913, E. gerardi Higgins, 1978, E. gizoensis Thormar \& Sørensen, 2010, E. imperforatus Higgins, 1983, E. kozloffi Higgins, 1977, E. lanceolatus Chang \& Song, 2002, E. pacificus Schmidt, 1974, E. sensibilis Adrianov et al., 2002, E. sublicarum Higgins, 1977, E. pilosus Lang, 1949, and E. worthingi Zelinka, 1928. These species were consequently selected for a comparative taxonomic approach. This study first of all enabled us to identify the Hawaiian species as E. sensibilis, but it also allowed us to identify a putative echinoderid species group, and carry out redescriptions and a revision of the species within this group.

\section{Material and methods}

Specimens for the present study were obtained from various different sources that are summarized in Table 1. Locality details on examined specimens are furthermore provided in the taxonomic accounts in the Results section. Whenever type material was available, it was loaned from the relevant repositories. This included, from the Smithsonian National Museum of Natural History (USNM), type material of E. gerardi, E. imperforatus, E. kozloffi, E. pacificus, and E. sublicarum, non-types of E. dujardinii and $E$. worthingi, and specimens of echinoderids from the Andaman Islands, India, that tentatively had been identified as Echinoderes cf. ehlersi (see Higgins \& Rao 1979). Type material of E. aureus and E. sensibilis was loaned from the Seto Marine Biological Laboratory (SMBL), and additional non-types of E. aureus from the Invertebrate Collection of the Hokkaido University Museum (ICHUM) and the Natural History Museum of Denmark (NHMD), type material of E. lanceolatus was loaned to co-author C.Y. Chang from the Natural History Museum of Ewha Woman's University (EWNHM), type material of E. pilosus was loaned to co-author H. Yamasaki from the Swedish Museum of Natural History (SMNH), and type material of E. gizoensis, and non-types of E. aureus, E. dujardinii, E. gerardi, E. kozloffi, $E$. sensibilis and E. worthingi from NHMD. Other non-type specimens of E. dujardinii and E. gerardi were loaned from Dr F. Pardos, Universidad Complutense de Madrid, and additional specimens of E. aureus, E. dujardinii, E. gerardi, E. kozloffi, E. sensibilis and E. worthingi were made available from the co-authors' personal reference collections.

Fresh material, collected for the present study, only included E. sensibilis collected during the Smithsonian workshop on Hawaii (see locality details in Results section). The specimens were collected either by hand or snorkelling, and were extracted live from the sediment using the bubbling and blot method (Higgins 1988), following the procedure described by Sørensen \& Pardos (2020). A few live specimens were selected for molecular barcoding, and were photographed live using a Canon Rebel T1i camera powered by EOS Utility software, mounted on a Leitz Laborlux 12 compound microscope, and subsequently transferred to $99 \%$ ethanol in individual tubes in a 96-well plate. Remaining specimens were picked up and transferred to a $4 \%$ formalin solution for fixation and subsequent preparation for microscopy. Sequencing of CO1 was completed at the Smithsonian NMNH Laboratories of Analytical Biology (LAB). The primers used were: forward LCO1490 GGTCAACAAATCATAAAGATATTGG and reverse HCO2198 TAAACTTCAGGGTGACCAAAAAATCA. The PCR program performed 
Table 1 (continued on next page). Species of Echinoderes Claparède, 1863 examined or studied for the present study. Types have kindly been loaned from ICHUM, NHMD, SMBL, SMNH, and USNM.

\begin{tabular}{|c|c|c|c|c|c|c|c|}
\hline Species & Type status & Cat. Number & Mounting & References & Locality & Habitat & Collectors \\
\hline E. aureus & $\begin{array}{l}\text { Paratypes } \\
\text { (incl. allotype), } \\
\text { non-types }\end{array}$ & $\begin{array}{l}\text { SMBL } 397-398 ; \\
\text { NHMD-662029 to } \\
662033 \text {, } \\
662035 \text { to } 602036 \text {, } \\
664219 \text { to } 664220 ; \\
\text { ICHUM-6124 to } 6126\end{array}$ & LM & $\begin{array}{l}\text { Adrianov } \\
\text { et al. } 2002 \mathrm{a}\end{array}$ & $\begin{array}{l}\text { Tanabe Bay } \\
\text { (type locality), } \\
\text { and Tanegashima, } \\
\text { Japan; Jeju Island, } \\
\text { Korea }\end{array}$ & $\begin{array}{l}\text { Detritus } \\
\text { and mixed } \\
\text { sediment of } \\
\text { tidal pools; } \\
\text { muddy sand }\end{array}$ & $\begin{array}{l}\text { A.V. Adrianov, } \\
\text { C. Murakami } \\
\text { and } \\
\text { Y. Shirayama; } \\
\text { H. Yamasaki; } \\
\text { J. Lee and } \\
\text { Y.H. Song }\end{array}$ \\
\hline $\begin{array}{l}\text { E. } \\
\text { chandrasekharai } \\
\text { sp. nov. } \\
(=\text { E. cf. ehlersi } \\
\text { sensu Higgins \& } \\
\text { Rao (1979)) }\end{array}$ & $\begin{array}{l}\text { Holotype, } \\
\text { paratypes, } \\
\text { non-types }\end{array}$ & $\begin{array}{l}\text { USNM-55391, } \\
\text { 55392, 55394, 55395, } \\
\text { 55397; } \\
\text { MVS ref. coll. }\end{array}$ & $\begin{array}{l}\text { LM and } \\
\text { SEM }\end{array}$ & $\begin{array}{l}\text { Higgins \& } \\
\text { Rao 1979; } \\
\text { present study }\end{array}$ & $\begin{array}{l}\text { Havelock Island } \\
\text { and South } \\
\text { Andaman Island, } \\
\text { Andaman Islands }\end{array}$ & $\begin{array}{l}\text { Intertidal mud } \\
\text { and sand with } \\
\text { macroalgae }\end{array}$ & $\begin{array}{l}\text { G.C. Rao; } \\
\text { T. Chatterjee }\end{array}$ \\
\hline E. dujardinii & non-types & $\begin{array}{l}\text { USNM-53342 } \\
\text { (RH125.02 to } \\
\text { 125.42); } \\
\text { NHMD-616804 to } \\
61807 \text {, } \\
\text { NHMD-616822 to } \\
616827 ; \\
\text { MVS ref. coll.; } \\
\text { Pardos ref. coll. }\end{array}$ & $\begin{array}{l}\text { LM and } \\
\text { SEM }\end{array}$ & $\begin{array}{l}\text { Higgins } \\
1977 \mathrm{a}\end{array}$ & $\begin{array}{l}\text { Roscoff (type } \\
\text { locality), France; } \\
\text { Faro, Portugal; } \\
\text { Spain (Atlantic): } \\
\text { Eo River; Arousa; } \\
\text { Vigo; Huelva }\end{array}$ & $\begin{array}{l}\text { Mud with } \\
\text { Zostera; mud; } \\
\text { muddy sand }\end{array}$ & $\begin{array}{l}\text { E.N. Kozloff; } \\
\text { R.C. Neves } \\
\text { and } \\
\text { M. Herranz; } \\
\text { Pardos Group }\end{array}$ \\
\hline E. ehlersi & - & - & - & $\begin{array}{l}\text { Zelinka 1913, } \\
1928\end{array}$ & $\begin{array}{l}\text { Zanzibar (type } \\
\text { locality), Tanzania }\end{array}$ & Unknown & Unknown \\
\hline E. gerardi & $\begin{array}{l}\text { Holotype, } \\
\text { non-types }\end{array}$ & $\begin{array}{l}\text { USNM-54841; } \\
\text { NHMD-616808 to } \\
616821 ; \\
\text { MVS ref. coll.; } \\
\text { Pardos ref. coll. }\end{array}$ & $\begin{array}{l}\text { LM and } \\
\text { SEM }\end{array}$ & Higgins 1978 & $\begin{array}{l}\text { Korbous (type } \\
\text { locality), Tunisia; } \\
\text { Turkey: Levantine } \\
\text { Sea: Antalya; } \\
\text { Aegean Sea: Çatal } \\
\text { Isl., Küçükbük, } \\
\text { Akbük, Çalış; } \\
\text { Spain (Atlantic): } \\
\text { Cadiz; Algeciras; } \\
\text { Spain } \\
\text { (Mediterranean): } \\
\text { Cabo de Palos; } \\
\text { Almería; Málaga; } \\
\text { Ceuta; Denia }\end{array}$ & $\begin{array}{l}\text { Debris from } \\
\text { sponges; algae; } \\
\text { sandy mud; } \\
\text { sand; red algae } \\
\text { (L. obtusa); } \\
\text { pebbles; shell } \\
\text { gravel }\end{array}$ & $\begin{array}{l}\text { F. Durucan; } \\
\text { K. Ruetzler; } \\
\text { N.Ö. Yildiz; } \\
\text { S. Sönmez and } \\
\text { S. Sak; } \\
\text { Pardos Group }\end{array}$ \\
\hline E. gizoensis & $\begin{array}{l}\text { Holotype, } \\
\text { paratypes }\end{array}$ & $\begin{array}{l}\text { NHMD-099742 to } \\
099744 \text { (formerly } \\
\text { ZMUC KIN-397 to } \\
\text { KIN-399) }\end{array}$ & $\begin{array}{l}\text { LM and } \\
\text { SEM }\end{array}$ & $\begin{array}{l}\text { Thormar \& } \\
\text { Sørensen } \\
2010\end{array}$ & $\begin{array}{l}\text { Ghizo (type } \\
\text { locality), Solomon } \\
\text { Islands }\end{array}$ & Coral sand & J. Thormar \\
\hline E. imperforatus & $\begin{array}{l}\text { Holotype, } \\
\text { paratypes }\end{array}$ & $\begin{array}{l}\text { USNM-69972 to } \\
69976\end{array}$ & LM & Higgins 1983 & $\begin{array}{l}\text { Twin Cays (type } \\
\text { locality), Belize }\end{array}$ & $\begin{array}{l}\text { Mixed } \\
\text { coralline mud } \\
\text { and sand with } \\
\text { seagrass }\end{array}$ & R.P. Higgins \\
\hline E. kozloffi & $\begin{array}{l}\text { Holotype, } \\
\text { paratypes, } \\
\text { non-types }\end{array}$ & $\begin{array}{l}\text { USNM-53337, 5339; } \\
\text { NHMD-100304 to } \\
\text { 100306, 616637; MH } \\
\text { ref. coll. }\end{array}$ & $\begin{array}{l}\text { LM and } \\
\text { SEM }\end{array}$ & $\begin{array}{l}\text { Higgins } \\
\text { 1977a; } \\
\text { Herranz \& } \\
\text { Leander } 2016\end{array}$ & $\begin{array}{l}\text { San Juan Isl. } \\
\text { (type locality), } \\
\text { Washington; } \\
\text { Calvert Isl. and } \\
\text { Victoria, BC, } \\
\text { Canada }\end{array}$ & $\begin{array}{l}\text { Black mud } \\
\text { rich in organic } \\
\text { matter; } \\
\text { intertidal } \\
\text { brown algae }\end{array}$ & $\begin{array}{l}\text { E.N. Kozloff; } \\
\text { M. Herranz }\end{array}$ \\
\hline E. lanceolatus & $\begin{array}{l}\text { Holotype, } \\
\text { paratypes, } \\
\text { non-types }\end{array}$ & EWNHM-60268 & LM & $\begin{array}{l}\text { Chang \& } \\
\text { Song } 2002\end{array}$ & $\begin{array}{l}\text { Beomseom, Jeju } \\
\text { Island, Korea (type } \\
\text { locality); East, } \\
\text { south and west } \\
\text { coast of Korea }\end{array}$ & $\begin{array}{l}\text { Mud with } \\
\text { shells; epizoic } \\
\text { on various } \\
\text { macro- } \\
\text { invertebrates; } \\
\text { algae and rock } \\
\text { surfaces; mud } \\
\text { with shell } \\
\text { fragments }\end{array}$ & $\begin{array}{l}\text { C.Y. Chang; } \\
\text { J. Lee; } \\
\text { S.H. Kim; } \\
\text { S.K. Paik; } \\
\text { Y.H. Song }\end{array}$ \\
\hline
\end{tabular}


Table 1 (continued).

\begin{tabular}{|c|c|c|c|c|c|c|c|}
\hline Species & Type status & Cat. Number & Mounting & References & Locality & Habitat & Collectors \\
\hline E. pacificus & $\begin{array}{l}\text { Holotype, } \\
\text { paratypes }\end{array}$ & USNM-53335, 53336 & LM & $\begin{array}{l}\text { Schmidt } \\
\text { 1974; } \\
\text { Higgins } \\
1977 \mathrm{a}\end{array}$ & $\begin{array}{l}\text { Santa Cruz } \\
\text { (type locality), } \\
\text { Galapagos Islands }\end{array}$ & $\begin{array}{l}\text { Black mud } \\
\text { rich in organic } \\
\text { matter }\end{array}$ & P. Schmidt \\
\hline E. pilosus & $\begin{array}{l}\text { Lectotype, } \\
\text { paralectotypes }\end{array}$ & $\begin{array}{l}\text { SMNH-3930; SMNH- } \\
\text { 1007, 9256-9261, } \\
\text { 9263-9280; } \\
\text { SMNH-9262, 9281- } \\
9282 \text { for SEM spec }\end{array}$ & $\begin{array}{l}\text { LM and } \\
\text { SEM }\end{array}$ & $\begin{array}{l}\text { Lang, 1949; } \\
\text { Higgins, } \\
1986\end{array}$ & $\begin{array}{l}\text { South Georgia } \\
\text { Island (type } \\
\text { locality) }\end{array}$ & Kelp & K. Lang \\
\hline E. sensibilis & $\begin{array}{l}\text { Holotype, } \\
\text { paratypes, } \\
\text { non-types }\end{array}$ & $\begin{array}{l}\text { CM-A-JAP-E4; CM- } \\
\text { A-JP-E01, E05, E08; } \\
\text { NHMD-115257, } \\
\text { NHMD-662049 } \\
\text { to } 662068, \\
664200 \text { to } 664204 ; \\
\text { ICHUM-6127 }\end{array}$ & $\begin{array}{l}\text { LM and } \\
\text { SEM }\end{array}$ & $\begin{array}{l}\text { Adrianov } \\
\text { et al. } 2002 b \text {; } \\
\text { present study }\end{array}$ & $\begin{array}{l}\text { Tanabe Bay (type } \\
\text { locality), Japan; } \\
\text { Sesoko Beach, } \\
\text { Okinawa, Japan; } \\
\text { Jeju Island, Korea; } \\
\text { Wido Island, } \\
\text { Korea; Kaneohe } \\
\text { Bay, Oahu, Hawaii }\end{array}$ & $\begin{array}{l}\text { Coralline red } \\
\text { algae; coarse, } \\
\text { intertidal } \\
\text { sand; black } \\
\text { mud rich in } \\
\text { organic matter; } \\
\text { intertidal } \\
\text { algae and rock } \\
\text { surfaces }\end{array}$ & $\begin{array}{l}\text { Adrianov et al.; } \\
\text { C.Y. Chang; } \\
\text { S. Fujimoto; } \\
\text { H. Yamasaki; } \\
\text { M.V. Sørensen }\end{array}$ \\
\hline $\begin{array}{l}\text { E. songae } \\
\text { sp. nov. }\end{array}$ & $\begin{array}{l}\text { Holotype, } \\
\text { paratypes, } \\
\text { non-types }\end{array}$ & $\begin{array}{l}\text { NHMD-662101 } \\
\text { to } 662112 ; \\
\text { NIBRIV0000866873 } \\
\text { to } \\
\text { NIBRIV0000866883; } \\
\text { HY ref. coll.; }\end{array}$ & $\begin{array}{l}\text { LM and } \\
\text { SEM }\end{array}$ & $\begin{array}{l}\text { Chang \& } \\
\text { Song 2002; } \\
\text { Yamasaki } \\
\text { et al. } 2014\end{array}$ & $\begin{array}{l}\text { Yeosu (type } \\
\text { locality), Korea; } \\
\text { East, south and } \\
\text { west coast of } \\
\text { Korea; Jeju Island, } \\
\text { Korea Strait; } \\
\text { Hokkaido and } \\
\text { Aomori, Japan }\end{array}$ & $\begin{array}{l}\text { Epizoic on } \\
\text { various macro- } \\
\text { invertebrates; } \\
\text { algae and rock } \\
\text { surfaces; mud } \\
\text { with shell } \\
\text { fragments }\end{array}$ & $\begin{array}{l}\text { C.Y. Chang; } \\
\text { H.S. Rho; } \\
\text { H. Yamasaki; } \\
\text { J. Lee; } \\
\text { S.H. Kim; } \\
\text { S.K. Paik; } \\
\text { Y.H. Song }\end{array}$ \\
\hline E. sublicarum & $\begin{array}{l}\text { Holotype, } \\
\text { paratypes }\end{array}$ & USNM-54397, 54399 & LM & $\begin{array}{l}\text { Higgins } \\
1977 \mathrm{~b}\end{array}$ & $\begin{array}{l}\text { Georgetown (type } \\
\text { locality), South } \\
\text { Carolina }\end{array}$ & $\begin{array}{l}\text { Epizoic on } \\
\text { Eudendrium } \\
\text { sp. (Hydrozoa) }\end{array}$ & W. Sikora \\
\hline E. worthingi & non-types & $\begin{array}{l}\text { NHMD-644454 to } \\
\text { 644455; SMNH- } \\
\text { 155944A to 155944B; } \\
\text { USNM-96034; } \\
\text { USNM-97282; MH } \\
\text { ref. coll. }\end{array}$ & $\begin{array}{l}\text { LM and } \\
\text { SEM }\end{array}$ & $\begin{array}{l}\text { Southern } \\
\text { 1914; } \\
\text { Higgins } 1985\end{array}$ & $\begin{array}{l}\text { Hirsholmene, } \\
\text { Denmark; Tjärnö } \\
\text { and Kungshamn, } \\
\text { Sweden (all three } \\
\text { northern Kattegat); } \\
\text { Roscoff, France; } \\
\text { Plymouth, UK; } \\
\text { Huelva, Spain }\end{array}$ & $\begin{array}{l}\text { Shell gravel, } \\
\text { mud, intertidal } \\
\text { rocks }\end{array}$ & $\begin{array}{l}\text { M.V. Sørensen; } \\
\text { G. Giribet; } \\
\text { E. Kozloff; } \\
\text { R.P. Higgins; } \\
\text { M. Herranz }\end{array}$ \\
\hline $\begin{array}{l}\text { Echinoderes sp. } \\
(=E \text {. cf. ehlersi } \\
\text { sensu Higgins } \\
\text { and Rao (1979)) }\end{array}$ & non-types & $\begin{array}{l}\text { USNM- } 55393,55396 \text {, } \\
55398 \text { to } 55400\end{array}$ & LM & $\begin{array}{l}\text { Higgins \& } \\
\text { Rao } 1979\end{array}$ & $\begin{array}{l}\text { Havelock Island } \\
\text { and South } \\
\text { Andaman Island, } \\
\text { Andaman Islands }\end{array}$ & $\begin{array}{l}\text { Intertidal mud } \\
\text { and sand with } \\
\text { macroalgae }\end{array}$ & G.C. Rao \\
\hline
\end{tabular}

initial denaturation at $95^{\circ} \mathrm{C}$ for $5 \mathrm{~min}, 35 \mathrm{cycles}$ of $95^{\circ} \mathrm{C}$ for $30 \mathrm{sec}, 48^{\circ} \mathrm{C}$ for $30 \mathrm{sec}, 72^{\circ} \mathrm{C}$ for $45 \mathrm{sec}$ with a final elongation of $72^{\circ} \mathrm{C}$ for $7 \mathrm{~min}$. The cycle sequencing protocol was 30 cycles of $95^{\circ} \mathrm{C}$ for $30 \mathrm{sec}, 50^{\circ} \mathrm{C}$ for $30 \mathrm{sec}, 60^{\circ} \mathrm{C}$ for $4 \mathrm{~min}$. The products were then cleaned with Sephadex columns and dried for sequencing. The DNA was sequenced using Applied Biosystems 3730xl DNA Analyzer and the raw read was analysed and assembled in Genious ver. R11.

Specimens for light microscopy (LM) were washed in distilled water, dehydrated through a graded waterglycerine series, and mounted in Fluoromount $\mathrm{G}$ between two cover glasses attached to a plastic H-S slide (EMS - Electron Microscopy Sciences, Cat\# 72268). The specimens were examined and photographed with an Olympus BX51 light microscope with differential interference contrast and an Olympus DP27 camera. All other specimens documented with LM were studied with the same microscope, except for the types of E. pilosus, and the Japanese specimens of E. aureus, E. sensibilis and E. songae Sørensen \& Chang sp. nov.collected by H. Yamasaki that were documented with a Zeiss Axioplan 2 compound microscope with a Zeiss AxioCam MRc5 camera, and the holotype of E. lanceolatus with an Olympus BX-51 differential interference contrast microscope and a Cool SNAP 5.0M camera (Roper Scientific Co., USA). 
Specimens for scanning electron microscopy (SEM) were transferred to distilled water, and cleaned by blowing bubbles through a solution of water and a small amount of liquid dish washing detergent (see Sørensen et al. 2018 for a more detailed description of the method). After an additional wash in clean distilled water, the specimens were transferred to SEM metal containers that were closed with $60 \mu \mathrm{m}$ nylon net in each end. The specimens were dehydrated through a graded ethanol series, transferred to acetone through an ethanol/acetone series, and critical point dried. The dried specimens were mounted on sticky carbon tabs on SEM aluminium stubs, sputter coated with a platinum/palladium mix, and examined with a JEOL JSM-6335F Field Emission SEM. All other specimens documented with SEM were studied with the same microscope, except for E. gerardi and E. pilosus, which were documented with a Zeiss EVO LS10 SEM.

All photos were edited (cropped, and adjustment of tone and contrast) with Adobe Photoshop CS6, and figure plates and line art illustrations were prepared with Adobe Illustrator CS6. Line art illustrations were based on light microscopical images imported into Illustrator, and information from SEM was added.

\section{Abbreviations}

The following abbreviations are for institutions and museums:

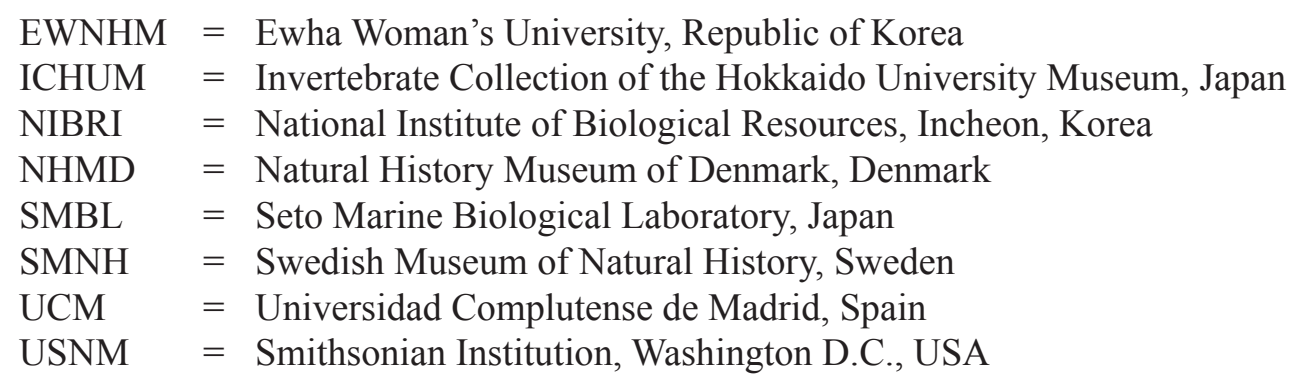

The following abbreviations are used in table legends:

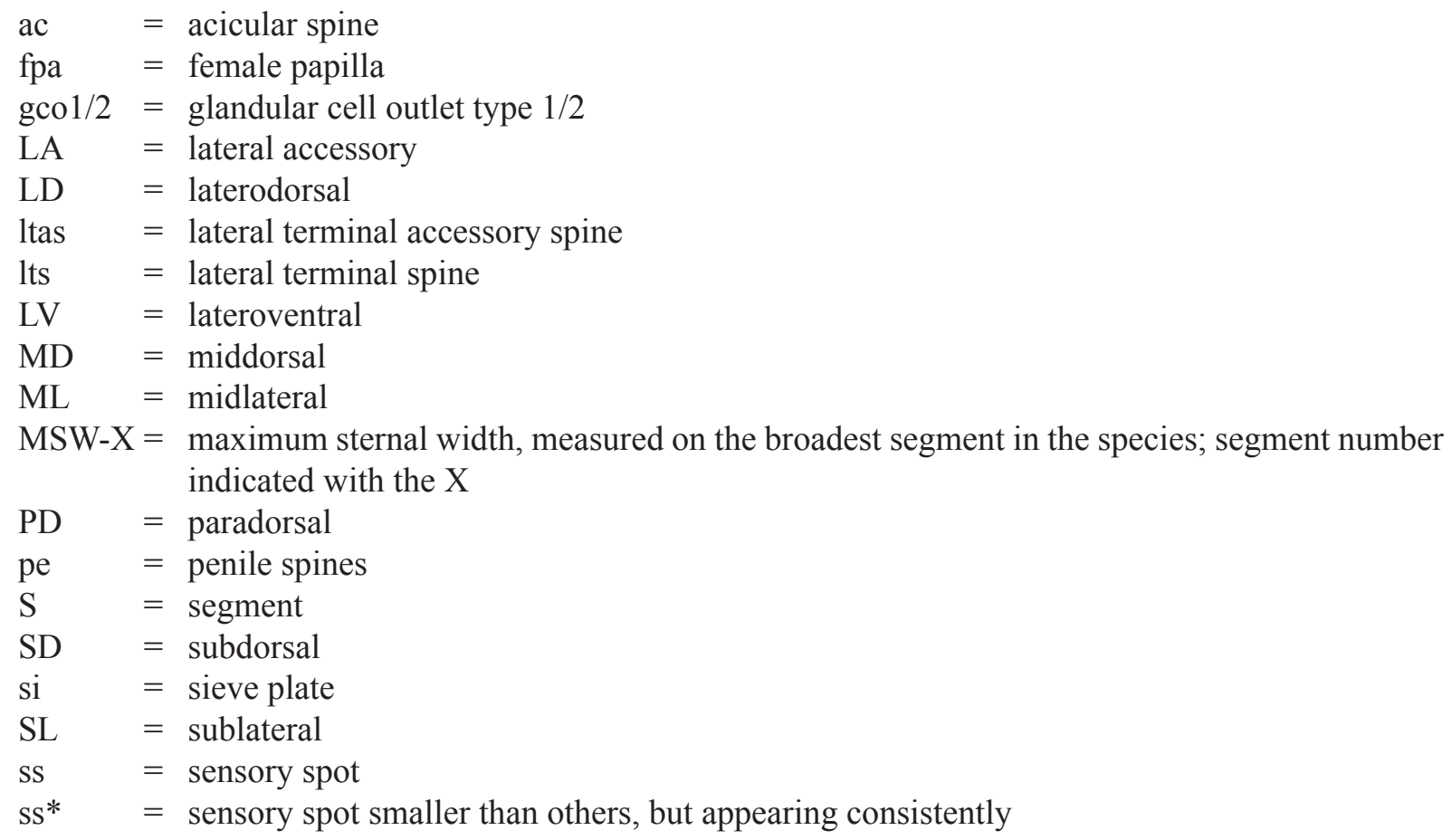




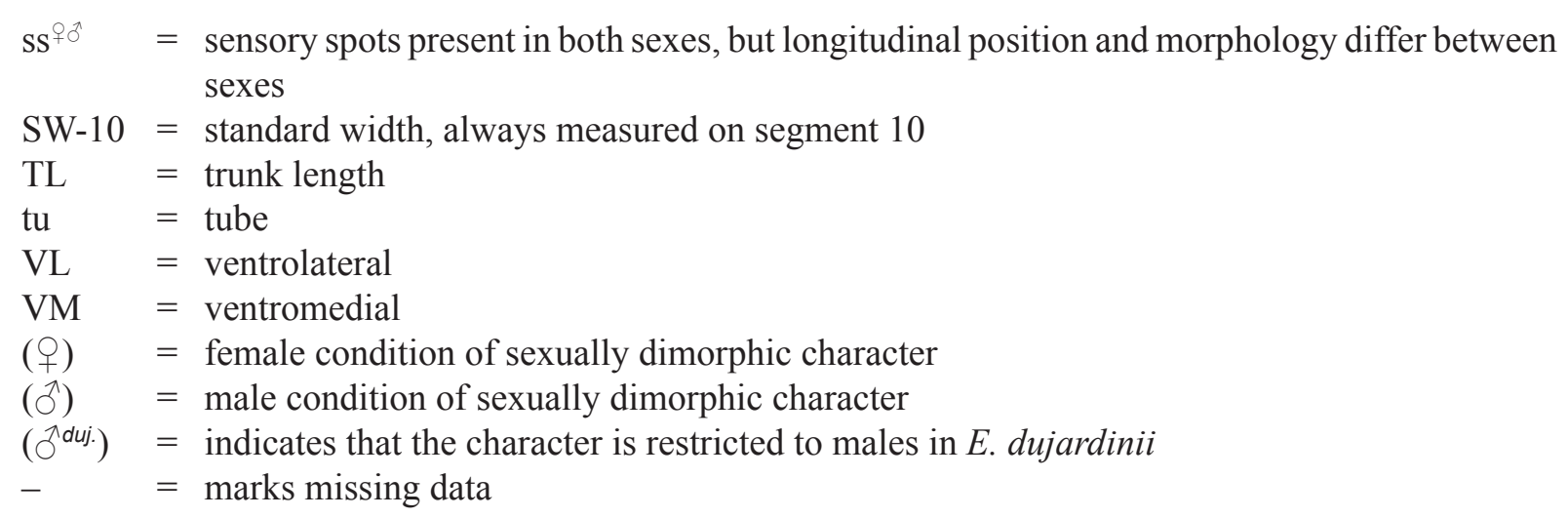

The following abbreviations are used in figure legends:

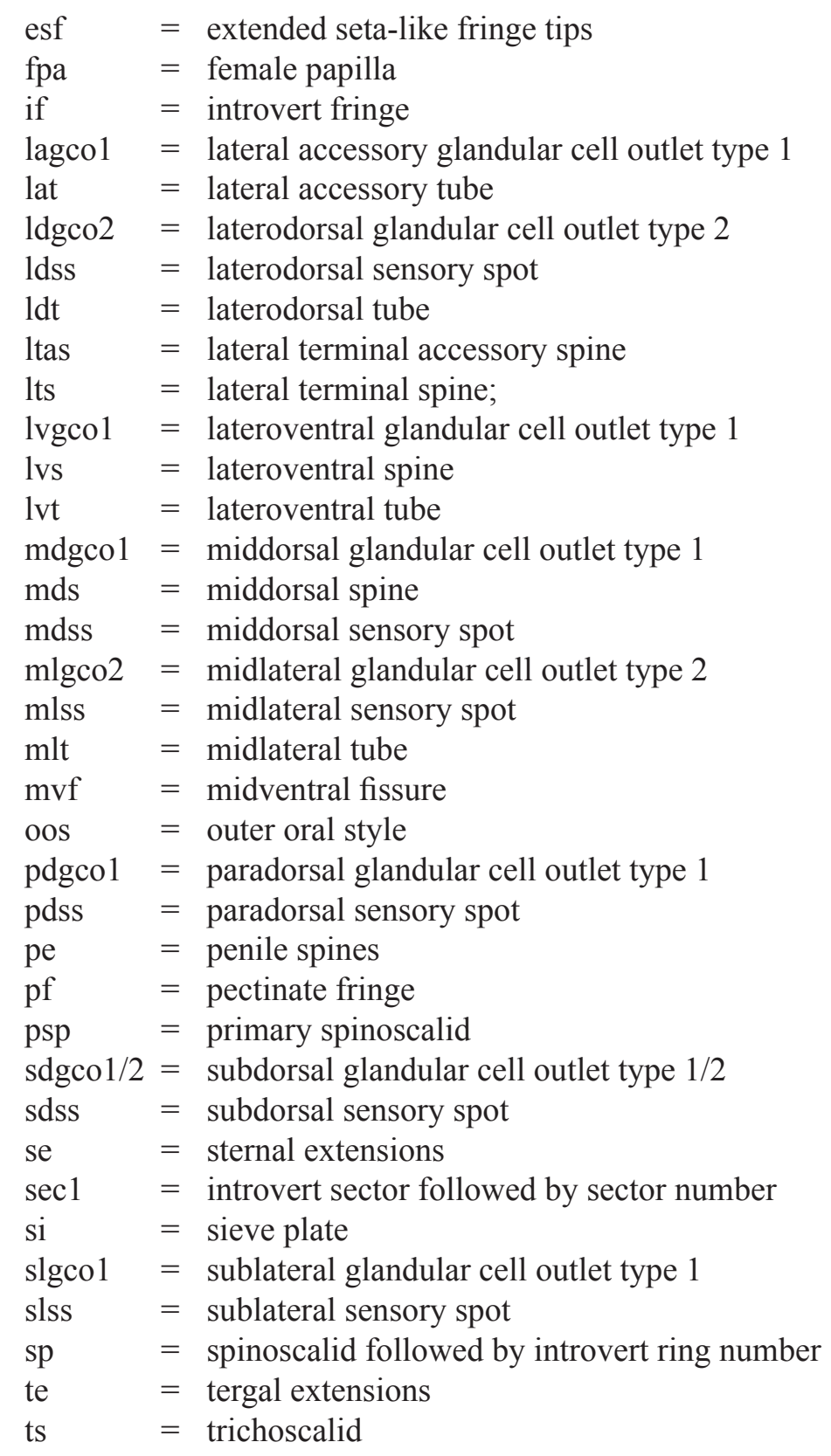




$$
\begin{array}{ll}
\text { tsp } & =\text { trichoscalid plate } \\
\text { vlgco1 } & =\text { ventrolateral glandular cell outlet type } 1 \\
\text { vlss } & =\text { ventrolateral sensory spot } \\
\text { vlt } & =\text { ventrolateral tube } \\
\text { vmgco1 } & =\text { ventromedial glandular cell outlet type } 1 \\
\text { vmss } & =\text { ventromedial glandular sensory spot }
\end{array}
$$

\section{Results}

\section{Species redescriptions}

Class Cyclorhagida Zelinka, 1896 sensu Sørensen et al. 2015

Order Echinorhagata Sørensen et al., 2015

Family Echinoderidae Zelinka, 1894

Genus Echinoderes Claparède, 1863

Echinoderes aureus Adrianov, Murakami \& Shirayama, 2002

Fig. 1; Table 2

Echinoderes aureus Adrianov Murakami \& Shirayama, 2002: 51-57, figs 2-6, table 1.

Echinoderes lanceolatus Chang \& Song, 2002: 204-210, figs 1-2. Syn. nov.

Echinoderes lanceolatus - Sørensen et al. 2012: 162, 180, 183. — Neuhaus 2013: tables 2, 6.

\section{Emended diagnosis}

Echinoderes with slender middorsal spines on segments 4 to 8, and lateroventral spines on segments 6 to 9 ; middorsal spines on posterior segments reach well beyond the posterior margin of their respective segments and overlap ca $50 \%$ of the following segment. Tubes present in ventrolateral positions on segment 2 , in lateroventral positions on segment 5 , and in midlateral positions on segment 10 . Incomplete midventral, intracuticular fissure present on anterior half of segment 2. Glandular cell outlets type 1 distributed in following pattern on dorsal side: middorsal on segments $1,2,3,5,7,10$ and 11 (two longitudinally aligned outlets on segments 10 and 11), and paradorsal on segments 4, 6, 8 and 9. Glandular cell outlets type 2 are not present on any segment. Tergal extensions of segment 11 are relatively slender, pointed and well-spaced, with strong pectinate fringe between extensions; sternal extensions short, nearly straight. Females with female papillae in ventrolateral positions on segments 7 and ventromedial positions on 8 .

\section{Material examined}

\section{Paratypes}

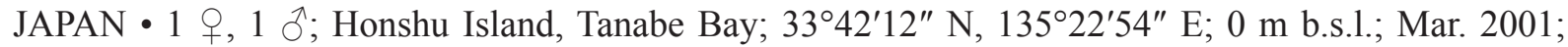
A. Adrianov, C. Murakami and Y. Shirayama leg.; brown algae (Padina arborescens) in tidal pool; SMBL-397, SMBL-398. Specimens mounted for LM.

Holotype and additional paratypes were not available.

\section{Additional material}

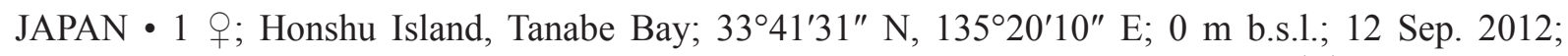

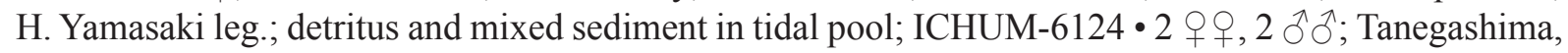
Mihama Beach; 3044'35" N, 13059'39" E; 0 m b.s.l.; 3 Mar. 2014; H. Yamasaki leg.; detritus and mixed sediment in tidal pool; NHMD-664219, NHMD-664220, ICHUM-6125, ICHUM-6126. 


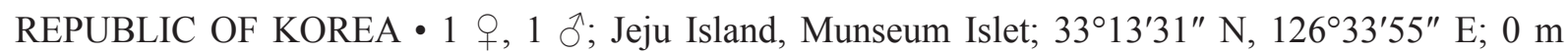
b.s.1.; 26 Feb. 1999; J. Lee and Y.H. Song leg.; intertidal macroalgae; NHMD-662029, NHMD-662030

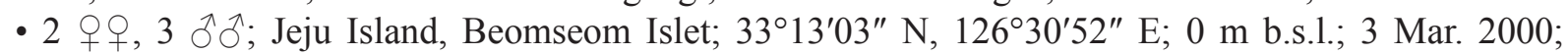
J. Lee and Y.H. Song leg.; intertidal macroalgae; NHMD-662031 to NHMD-662033, NHMD-662034 to NHMD-662036.

All specimens are mounted for LM. One of the specimens from Beomseom Islet was designated as paratype for Echinoderes lanceolatus. In addition to these specimens, photographs of the holotype of E. lanceolatus, also collected at Beomseom Islet, were examined. No specimens mounted for SEM were available. See Table 1 for an overview.

\section{Description}

The appearance of the species generally follows the description provided by Adrianov et al. (2002a), hence the following notes only provide additional information not included in the original description. The presence of an incomplete midventral, intracuticular fissure on anterior half of segment 2 is confirmed from all examined specimens (Fig. 1E). Our observations also confirmed the presence of rounded ventromedial, intra- or subcuticular markings on segment 1, but it should be stressed that these markings can be very difficult to visualize, and seem to get even harder to see in older specimens. We can furthermore confirm the absence of glandular cell outlets type 2 on any segment. Middorsal spines are thin, and the spine of segment 8 extends well beyond the posterior segment margin and overlaps half of segment 9 (Fig. 1I). Female papillae forming a short, tubular intracuticular structure are present in ventrolateral positions on segment 7 and ventromedial positions on segment 8 (Fig. 1H). Tergal plates of segment 11 have conspicuously strong pectinate fringes in the area between the tergal extensions (Fig. 1J). Seta-like fringe tips not observed from neither tergal nor sternal extensions. Lateral terminal accessory spines short (about $1 / 3$ of lateral terminal spine length), and conspicuously thick and stout (Fig. 1J).

The distribution of cuticular structures, i.e., sensory spots, glandular cell outlets, tubes, and spines is summarized in Table 2. Distribution of sensory spots generally follows the original species description, but with several differences. Dorsal series: original description: paradorsal sensory spots on segment 2 present in males; specimens examined herein: paradorsal sensory spots absent on segment 2 in males, but middorsal sensory spot present in both sexes. Original description: one pair of laterodorsal sensory spots on segment 2 present in males; specimens examined herein: two pairs of laterodorsal sensory spots on segment 2 present in both sexes (Fig. 1D). Original description: midlateral sensory spots on segment 3 absent in males; specimens examined herein: midlateral sensory spots on segment 3 present in both sexes. Original description: laterodorsal sensory spots on segment 3 present in females; specimens examined herein: these sensory spots are present in both sexes but appear in midlateral rather than laterodorsal positions (Fig. 1D). Original description: laterodorsal sensory spots on segments 4 to 7 present in males; specimens examined herein: these sensory spots appear in midlateral rather than laterodorsal positions (Fig. $1 \mathrm{~F}-\mathrm{G}$ ), and are also present on segment 8. Original description: no mention of laterodorsal or midlateral sensory spots on segments 4 to 8 in females; specimens examined herein: midlateral sensory spots present on segments 4 to 8 in females (Fig. 1F-G). Original description: subdorsal sensory spots on segments 5 and 7 absent in males; specimens examined herein: subdorsal sensory spots on segments 5 and 7 present in males. Original description: one pair of subdorsal sensory spots on segment 6 present in females; specimens examined herein: two pairs of subdorsal sensory spots on segment 6 present in females (Fig. 1G). Original description: no mention of laterodorsal sensory spots on segment 9 in any sex; specimens examined herein: laterodorsal sensory spots present on segment 9 in both sexes. Original description: segments 10 and 11 have a middorsal sensory spot anterior to a middorsal glandular cell outlet type 1; specimens examined herein: segments 10 and 11 have two middorsal, longitudinally aligned glandular cell outlets type 1 . The distribution of glandular cell outlets type 1 on the dorsal 

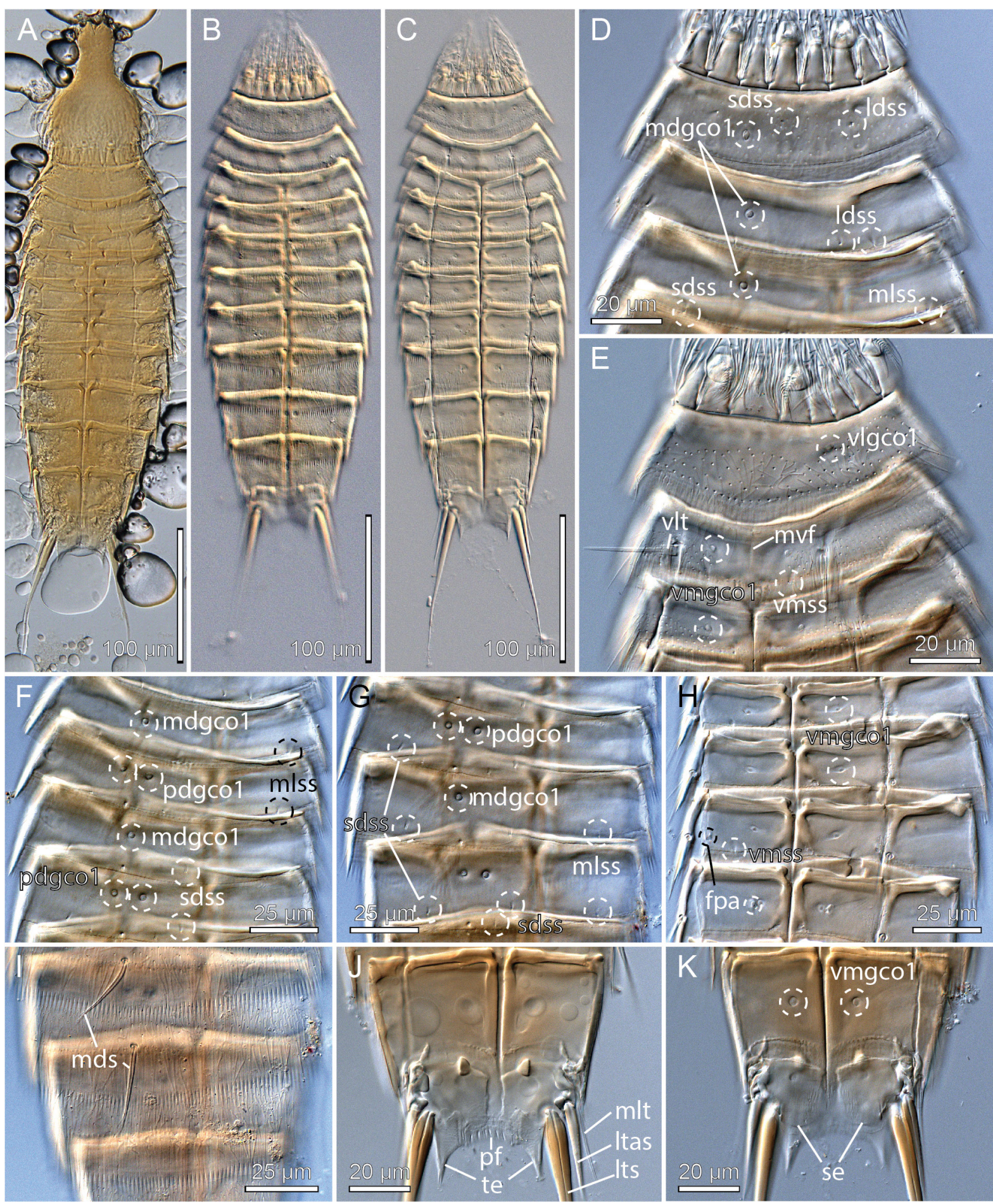

Fig. 1. Light micrographs showing overviews and details of Echinoderes aureus Adrianov et al., 2002. A. Allotype, $q$ (SMBL-397). B-C. Non-type $q$ from Tanegashima (NHMD-664220). D-K. Topotype, q (ICHUM-6124 ). A. Ventral overview. B. Dorsal overview. C. Ventral overview. D. Segments 1 to 3, dorsal view. E. Segments 1 to 3, ventral view. F. Segments 3 to 6, dorsal view. G. Segments 6 to 8 , dorsal view. H. Segments 6 to 8, ventral view, showing female sexual dimorphism. I. Segments 7 to 9 , dorsal view. J. Segments 10 to 11, focused on posterior margin of tergal plate of segment 11, showing female sexual dimorphism. K. Segments 10 to 11, ventral view, showing female sexual dimorphism. 
Table 2. Summary of nature and location of sensory spots, glandular cell outlets, tubes and spines arranged by series in Echinoderes aureus Adrianov et al., 2002.

\begin{tabular}{|c|c|c|c|c|c|c|c|c|c|c|}
\hline $\begin{array}{c}\text { Position } \\
\text { Segment }\end{array}$ & MD & PD & SD & LD & ML & SL & LA & LV & VL & VM \\
\hline 1 & gcol & & ss & ss & & ss & & & gcol & \\
\hline 2 & gco1, ss & & & ss,ss & & & & & tu & ss, gco1 \\
\hline 3 & gcol & & ss & & ss & & & & & gcol \\
\hline 4 & $\mathrm{ac}$ & gcol & ss & & ss & & & & & gcol \\
\hline 5 & gcol, ac & & ss & & ss & & & tu & & ss, gcol \\
\hline 6 & $\mathrm{ac}$ & gcol, ss & ss, ss & & ss & & & $\mathrm{ac}$ & & gcol \\
\hline 7 & gcol, ac & & ss & & ss & & & $\mathrm{ac}$ & fpa $(+)$ & ss, gcol \\
\hline 8 & $\mathrm{ac}$ & gcol & ss & & ss & & & $\mathrm{ac}$ & & 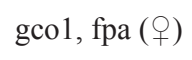 \\
\hline 9 & & gcol & ss, ss & ss & & & si & $\mathrm{ac}$ & ss & gcol \\
\hline 10 & gco1, gco1 & & ss & & tu & & & & ss $(\overbrace{}^{\lambda})$ & gco1 \\
\hline 11 & gco1, gco1 & & ss & & $3 x p e\left(0^{1}\right)$ & & $\operatorname{ltas}(q)$ & lts & & \\
\hline
\end{tabular}

side of segments 1 to 9 fits the original description. Ventral series: Original description: ventromedial sensory spots on segment 1 in males; specimens examined herein: ventromedial sensory spots absent on segment 1 in both sexes. Original description: ventromedial sensory spots are illustrated on segments 2 to 10; specimens examined herein: these structures are glandular cell outlets type 1 (Fig. 1E, H, K), and not sensory spots; however besides these outlets, both sexes have ventromedial sensory spots on segments 5 and 7, and ventrolateral ones on segment 9; males furthermore with ventrolateral sensory spots on segment 10 .

Echinoderes dujardinii Claparède, 1863

Figs 2-4; Tables 3-4

l'Echinodère Dujardin 1851: 158, pl. 3, figs 1-4.

Echinoderes Dujardinii Claparède, 1863: 90-92, pl. 16, figs 7-13.

Echinoderes dujardinii - Higgins 1977a: 4-13, figs 1-12. — Sánchez et al. 2012: 26 [South Galicia].

Non Echinoderes dujardinii - Mari \& Morselli 1987: 117. — Sánchez-Tocino et al. 2011: 179-184, figs 1-4, tables 1-2. — Sánchez et al. 2012: 26 [Algeciras, Granada, Murcia, Alicante]. — Ürkmez et al. 2016: 1-8, figs 2-4.

\section{Emended diagnosis}

Echinoderes with short middorsal spines on segments 4 to 8, and lateroventral spines on segments 6 to 9 ; middorsal spines on segments 7 and 8 might reach posterior margins of their respective segments, but they never extend beyond the margins. Tubes present in lateroventral positions on segments 2 and 5 , in lateral accessory positions on segment 8 , and in laterodorsal positions on segment 10 . Minute glandular cell outlets type 2 in laterodorsal positions on segments 8 and 9; those on segment 9 situated anterior to laterodorsal sensory spots. Tergal extensions of segment 11 short, pointed and well-spaced; sternal extensions short, with ventrolateral seta-like tuft of extended fringe tips. Females with ventromedial female papillae resembling glandular cell outlets type 2 on segments 6 to 8 ; intracuticular substructure of papillae on segment 6 is crescentic, substructure on segments 7 and 8 is tubular. 


\section{Material examined}

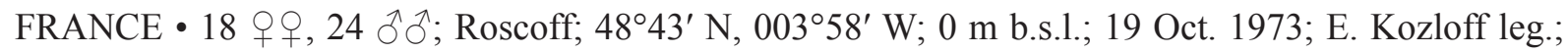
sandy mud (see Higgins 1977a); USNM-53342. Specimens mounted for LM.

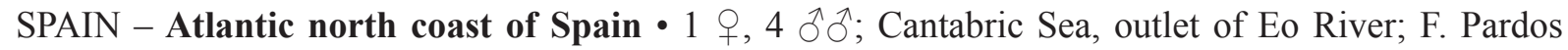
leg.; UCM. - Galician Atlantic west coast of Spain • 1 q; Arousa; F. Pardos leg.; UCM • 1 ô; Vigo; F. Pardos leg.; UCM. - Andalusian Atlantic south coast of Spain - 3 우, 1 đ ; Huelva; F. Pardos leg.; UCM. Specimens mounted for LM.

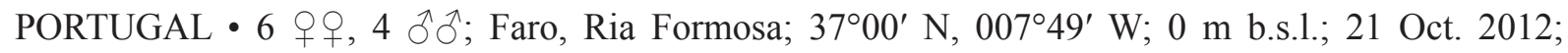
R.C. Neves and M. Herranz leg.; mud with Zostera; NHMD-616804 to 616807, NHMD-616822 to 616827. Specimens mounted for LM.

About 30 specimens from the same locality at Faro were mounted for SEM and stored in the first author's personal reference collection. Type material was not available. See Table 1 for an overview.

\section{Description}

Echinoderes dujardinii was redescribed by Higgins (1977a), but due to the numerous new details (mainly revealed by SEM), reinterpretations of cuticular structures, and considerable changes in terminology over the past 40 years, we are providing a full description of the species.

Adults with head, neck and eleven trunk segments (Figs 2A, 3, 4A). Trunk with nearly equally broad sternal plates on segments 5 to 10 (Fig. 2A). Lateral terminal spines slender, from $40 \%$ to $55 \%$ of trunk length. Secondary pectinate fringe formed as one fringed band near anterior segment margin is present on segments 2 to 10. For complete overview of measurements and dimensions of Portuguese and Spanish populations, see Table 3. Distribution of cuticular structures, i.e., sensory spots, glandular cell outlets, spines and tubes, is summarized in Table 4.

The head consists of a retractable mouth cone and an introvert (Figs 3, 4B). Three rings of inner oral styles, apparently with five styles in each ring. The external mouth cone armature consists of nine outer oral styles, each consisting of two joined units and arranged as one style anterior to each introvert sector, except the middorsal sector 6; each outer oral style basally flanked by pair of lateral spikes, followed by more basal V-shaped row of fringe tips, and again followed by even more basal brush-like arch of bristles (Fig. 4B). The introvert sectors are defined by the ten primary spinoscalids in Ring 01 (Fig. 3). Each primary spinoscalid consists of a basal sheath and a distal end piece with a blunt tip. The sheaths have two distinctively differentiated fringes: a most basal, transverse fringe, and a slightly more distal fringe where the fringe tips bend in a curve near their attachment point, and fuse to the scalid along a longitudinal line, giving the attachment area a conspicuous appearance (see inset Fig. 4B). End pieces are smooth and flexible. Rings 02 and 04 have 10 spinoscalids and Rings 03 and 05 have 20. All spinoscalids in these rings are well-developed, and consist of a basal sheath and a pointed end piece. The basal sheaths terminate into fine, fringed margins in spinoscalids of Rings 02 to 05 , and those of Ring 03 have in addition a basal median spike (Fig. 4B inset). A ring of short fringes extend around the introvert in between spinoscalid Rings 05 and 06 . Ring 06 has only six spinoscalids, located in sectors 1, 3, 5, 6, 7, and 9; ring 06 spinoscalids resemble those in preceding sectors, but are much shorter and with densely haired end pieces. Ring 07 has 7 spinoscalids, located as pairs in sectors 3 and 9, unpaired but laterally displaced in sectors 5 and 7 (trichoscalids are taking up the space in the opposite side of each sector), and unpaired but centred in sector 1; ring 07 spinoscalids resemble those in preceding sector but are even shorter.

Described sector-wise (Fig. 3), sector 1 has spinoscalids arranged as two double diamonds anterior to a single Ring 7 spinoscalid. Sectors 2, 4, 8 and 10 all have spinoscalids arranged as a quincunx, 

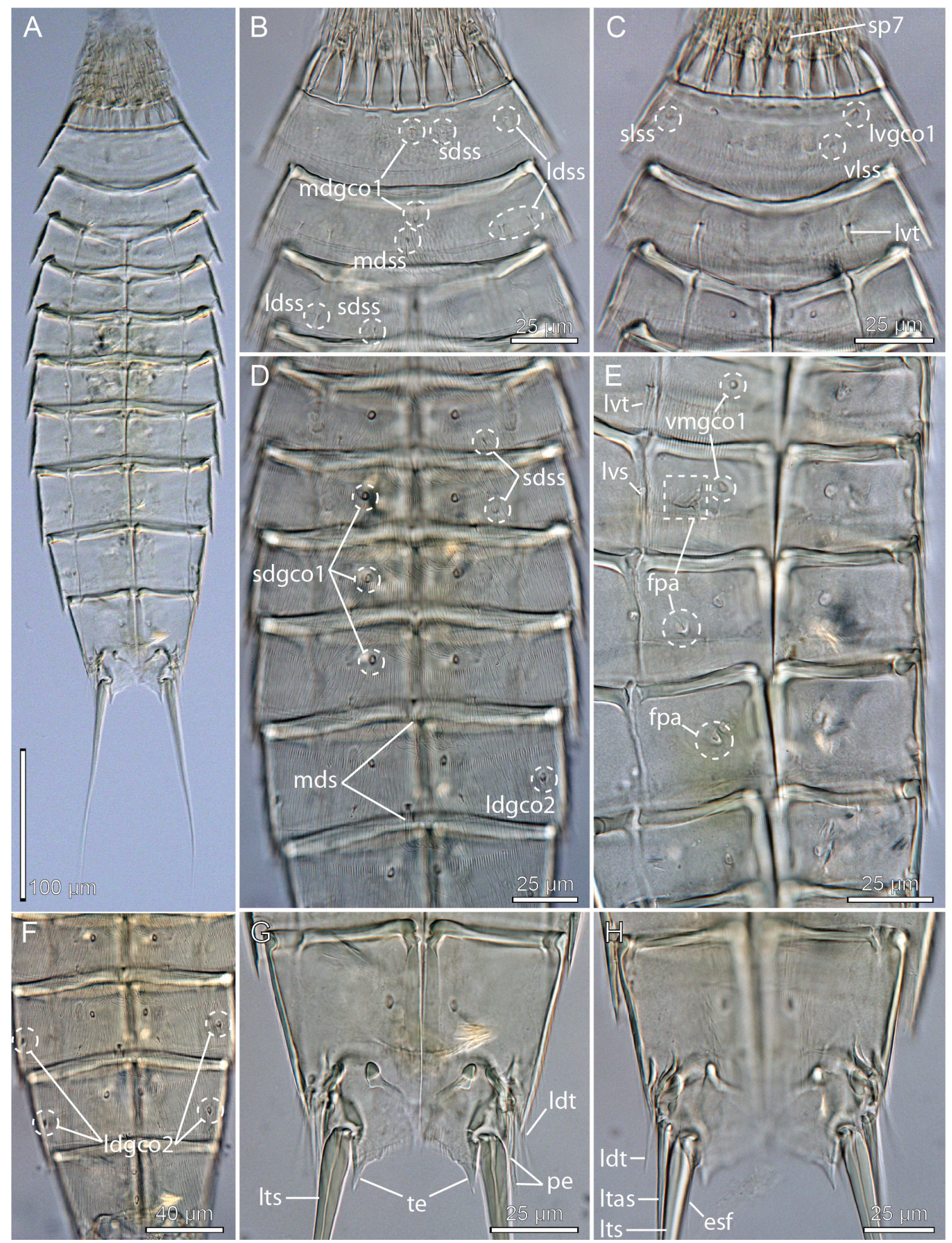

Fig. 2. Light micrographs showing overviews and details of Echinoderes dujardinii Claparède, 1863, non-types from Ria Formosa, Faro, Portugal. A-D, F-G. ô (NHMD-616804). E, H. क (NHMD-616824). A. Ventral overview. B. Segments 1 to 3, dorsal view. C. Segments 1 to 3, ventral view. D. Segments 4 to 9, dorsal view. E. Segments 5 to 9, ventral view, showing female sexual dimorphism. F. Segments 7 to 10 , dorsal view. G. Segments 10 to 11, ventral view, showing male sexual dimorphism. H. Segments 10 to 11 , ventral view, showing female sexual dimorphism. 


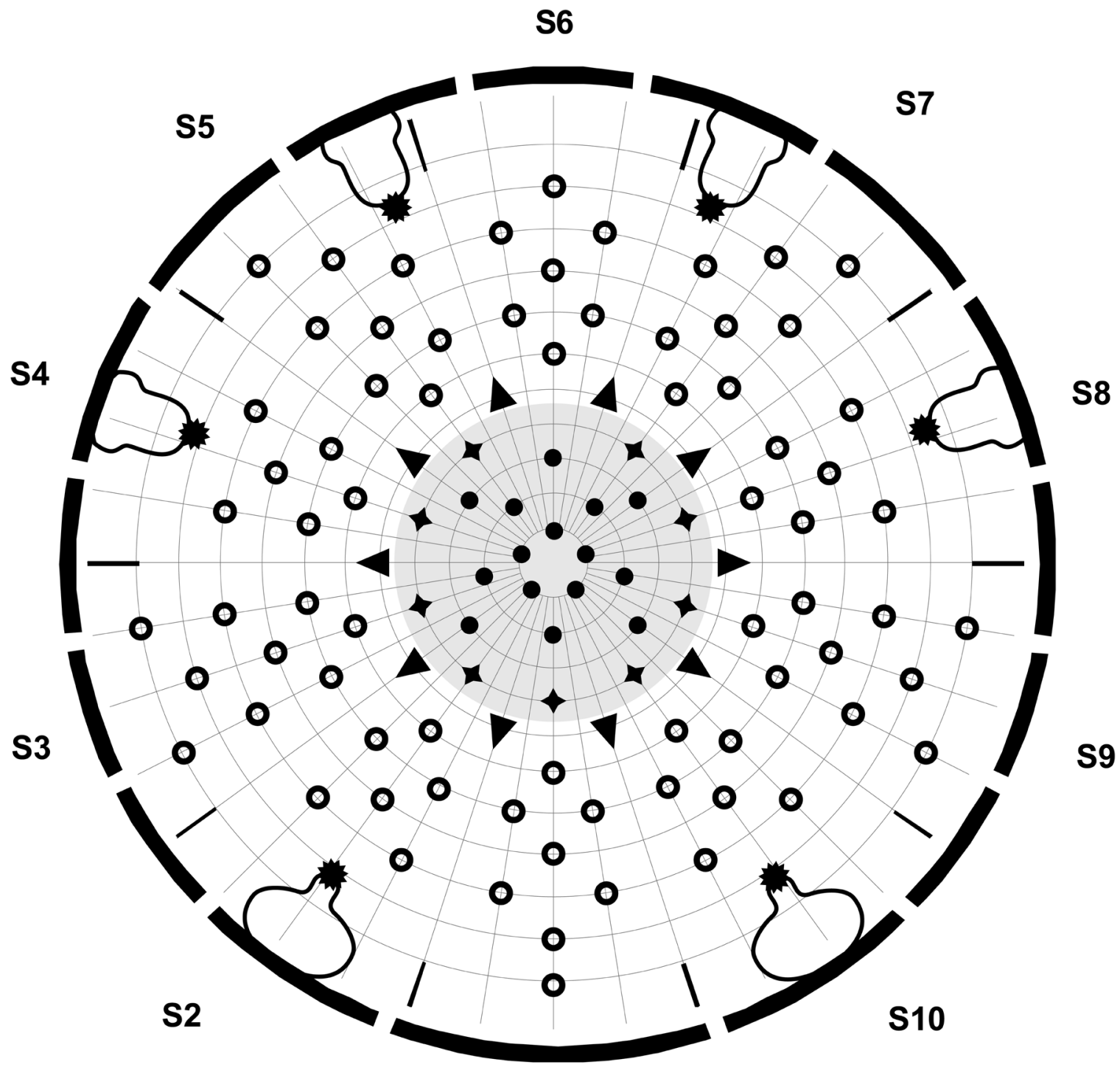

S1

Scalid and style arrangement

\begin{tabular}{|c|c|c|c|c|c|c|c|c|c|c|c|c|c|c|}
\hline \multicolumn{2}{|c|}{ Ring/Section } & 1 & 2 & 3 & & 4 & 5 & 6 & & 7 & 8 & 9 & 10 & Total \\
\hline \multicolumn{2}{|c|}{00 outer oral styles } & & 1 & 1 & & 1 & 1 & $\overline{0}$ & & 1 & 1 & 1 & 1 & 9 \\
\hline \multicolumn{2}{|c|}{01 primary spinoscalids $\nabla$} & 1 & 1 & 1 & 1 & 1 & & & 1 & & 1 & 1 & 1 & 10 \\
\hline 02 spinoscalids & 0 & 1 & 1 & 1 & & 1 & 1 & 1 & & 1 & 1 & 1 & 1 & 10 \\
\hline 03 spinoscalids & 0 & 2 & 2 & 2 & & 2 & 2 & 2 & & 2 & 2 & 2 & 2 & 20 \\
\hline 04 spinoscalids & $\mathbf{0}$ & 1 & 1 & 1 & & 1 & 1 & 1 & & 1 & 1 & 1 & 1 & 10 \\
\hline 05 spinoscalids & 0 & 2 & 2 & 2 & & 2 & 2 & 2 & & 2 & 2 & 2 & 2 & 20 \\
\hline 06 spinoscalids & $\mathbf{0}$ & 1 & 0 & 1 & & 0 & 1 & 1 & & 1 & 0 & 1 & 0 & 6 \\
\hline 07 spinoscalids & 0 & 1 & 0 & 2 & & 0 & 1 & 0 & & 1 & 0 & 2 & 0 & 7 \\
\hline \multicolumn{2}{|c|}{ Total scalids } & 8 & 6 & 9 & & 6 & 8 & 7 & & 8 & 6 & 9 & 6 & 73 \\
\hline trichoscalids & \% & 0 & 1 & 0 & & 1 & 1 & 0 & & 1 & 1 & 0 & 1 & 6 \\
\hline
\end{tabular}

Fig. 3. Diagram of mouth cone (grey area), introvert and placids in Echinoderes dujardinii Claparède, 1863, showing distribution of inner oral styles (full circles), outer oral styles (diamonds), primary scalids (triangles), spinoscalids (thick open circles), and trichoscalids (stars), with positions of trichoscalid plates and placids indicated. Table shows the scalid arrangement by sector; single-lined boxes mark quincunxes, double-lined boxes mark 'double diamonds'. 
Table 3. Measurements from light microscopy for specimens of Echinoderes dujardinii Claparède, 1863 from various localities along the Atlantic coasts of Spain and Portugal (in $\mu \mathrm{m}$ ), including number of measured specimens $(n)$ and standard deviation (SD). Right column (Range All + Roscoff) shows ranges of Spanish and Portuguese populations merged with ranges from the French Roscoff population examined by Higgins (1977a).

\begin{tabular}{|c|c|c|c|c|c|c|c|c|c|c|}
\hline \multirow{2}{*}{ Character } & \multirow{2}{*}{$\begin{array}{c}\text { Eo River } \\
+ \\
+\end{array}$} & \multirow{2}{*}{$\begin{array}{c}\text { Arousa } \\
\quad+\end{array}$} & \multirow{2}{*}{$\underset{\substack{1 \\
\text { Vigo }}}{0}$} & \multirow{2}{*}{ Faro Range } & \multirow{2}{*}{$\begin{array}{l}\text { Huelva } \\
\text { Range }\end{array}$} & \multicolumn{4}{|c|}{ All Spanish and Portuguese specimens } & \multirow{2}{*}{$\begin{array}{c}\text { Range } \\
\text { All + Roscoff }\end{array}$} \\
\hline & & & & & & Range & Mean & SD & $n$ & \\
\hline $\mathrm{L}$ & 392 & 344 & 320 & $351-408$ & $322-372$ & $320-408$ & 363 & 27.34 & 17 & $320-408$ \\
\hline MSW-8 & 86 & 88 & 76 & $78-87$ & $81-88$ & $76-88$ & 83 & 3.28 & 17 & $76-88$ \\
\hline MSW-8/TL & $21.9 \%$ & $25.6 \%$ & $23.8 \%$ & $20.3-23.7 \%$ & $22.6-26.2 \%$ & $20.3-26.2 \%$ & $23.0 \%$ & $1.85 \%$ & 17 & $19.4-26.2 \%$ \\
\hline SW-10 & 80 & 80 & 73 & $69-79$ & $78-82$ & $69-82$ & 76 & $4.12 \%$ & 17 & $69-82$ \\
\hline SW-10/TL & $20.4 \%$ & $23.3 \%$ & $22.8 \%$ & $18.3-20.8 \%$ & $21.2-25.3 \%$ & $18.3-25.3 \%$ & $20.9 \%$ & $2.20 \%$ & 17 & $18.3-25.3 \%$ \\
\hline S1 & 37 & 38 & 34 & $34-37$ & $34-36$ & $34-38$ & 36 & 1.13 & 17 & $31-41$ \\
\hline S2 & 38 & 37 & 34 & $37-40$ & $35-38$ & $34-40$ & 37 & 1.46 & 17 & $34-41$ \\
\hline S3 & 41 & 37 & 43 & $38-42$ & $37-40$ & $37-43$ & 40 & 1.83 & 17 & $37-43$ \\
\hline S4 & 41 & 40 & 43 & $41-45$ & $39-43$ & $39-45$ & 42 & 1.73 & 17 & $39-45$ \\
\hline S5 & 45 & 45 & 49 & $43-49$ & $41-46$ & $41-49$ & 46 & 2.34 & 17 & $41-49$ \\
\hline S6 & 46 & 46 & 50 & $48-54$ & $43-49$ & $43-54$ & 49 & 2.95 & 17 & $43-54$ \\
\hline S7 & 55 & 54 & 58 & $52-58$ & $46-53$ & $46-58$ & 54 & 3.13 & 17 & $46-58$ \\
\hline S8 & 56 & 59 & 51 & $57-62$ & $53-56$ & $51-62$ & 57 & 2.83 & 17 & $51-63$ \\
\hline S9 & 62 & 63 & 52 & $57-62$ & $53-56$ & $52-63$ & 58 & 3.55 & 17 & $52-65$ \\
\hline $\mathrm{S} 10$ & 58 & 56 & 49 & $53-61$ & $48-53$ & $48-61$ & 55 & 3.46 & 17 & $48-61$ \\
\hline S11 & 48 & 45 & 41 & $41-49$ & $41-43$ & $41-49$ & 44 & 2.35 & 17 & $40-49$ \\
\hline MD4 (ac) & - & 20 & - & $13-17$ & $10-13$ & $10-20$ & 14 & 2.80 & 13 & $10-20$ \\
\hline MD5 (ac) & - & 21 & - & $14-18$ & $10-15$ & $10-21$ & 15 & 2.94 & 13 & $10-21$ \\
\hline MD6 (ac) & 16 & 21 & - & $14-18$ & $12-16$ & $12-21$ & 17 & 2.41 & 14 & $11-23$ \\
\hline MD7 (ac) & 17 & 21 & - & $16-22$ & $14-17$ & $14-22$ & 18 & 2.44 & 15 & $13-22$ \\
\hline MD8 (ac) & 23 & 23 & - & $18-23$ & $18-19$ & $18-23$ & 21 & 2.18 & 14 & $16-27$ \\
\hline LV2 (tu) & 24 & & - & $19-24$ & 23 & $19-24$ & 23 & 1.75 & 12 & $17-28$ \\
\hline LV5 (tu) & 20 & 20 & - & $16-21$ & - & $16-21$ & 19 & 1.66 & 12 & $13-26$ \\
\hline LV6 (ac) & 17 & 18 & 15 & $14-20$ & $12-17$ & $12-20$ & 16 & 2.00 & 17 & $12-26$ \\
\hline LV7 (ac) & 21 & 18 & 18 & $16-21$ & $14-17$ & $14-21$ & 18 & 2.14 & 17 & $14-28$ \\
\hline LV8 (ac) & 20 & 21 & 18 & $18-26$ & $14-19$ & $14-26$ & 20 & 2.76 & 17 & $14-26$ \\
\hline LA8 (tu) & - & 19 & 15 & $15-20$ & $12-19$ & $12-20$ & 17 & 2.30 & 10 & $12-26$ \\
\hline LV9 (ac) & 25 & 19 & 19 & $19-25$ & $17-19$ & $17-25$ & 21 & 2.60 & 17 & $17-28$ \\
\hline LD10 (tu) & - & - & - & $24-38$ & 19 & $19-28$ & 25 & 2.92 & 9 & $19-33$ \\
\hline LTS & 179 & 172 & 149 & $161-190$ & 169-197 & 149-197 & 177 & 11.78 & 16 & 149-197 \\
\hline LTS/TL & $45.7 \%$ & $50.0 \%$ & $46.6 \%$ & $39.5-51.6 \%$ & $45.4-60.8 \%$ & $39.5-60.8 \%$ & $48.9 \%$ & $5.69 \%$ & 16 & $39.5-60.8 \%$ \\
\hline LTAS & 64 & 63 & N/A & $41-56$ & $44-54$ & $41-64$ & 51 & 7.84 & 11 & $41-64$ \\
\hline
\end{tabular}


Table 4. Summary of nature and location of sensory spots, glandular cell outlets, tubes and spines arranged by series in Echinoderes dujardinii Claparède, 1863 and E. gerardi Higgins, 1978.

\begin{tabular}{|c|c|c|c|c|c|c|c|c|c|c|}
\hline $\begin{array}{l}\text { Position } \\
\text { Segment }\end{array}$ & MD & PD & SD & LD & ML & SL & LA & $\mathbf{L V}$ & VL & VM \\
\hline 1 & gcol & & ss & ss & & ss & & gcol & ss & \\
\hline 2 & gcol, ss & & & ss, ss & & & & tu & & ss, gco1 \\
\hline 3 & gcol & & ss & ss & & ss & & & & gcol \\
\hline 4 & $\mathrm{ac}$ & & gcol, ss & & ss* & & & & & ss, gcol \\
\hline 5 & $\mathrm{ac}$ & & gcol, ss & & ss & & & tu & & ss, gcol \\
\hline 6 & ac & ss & gcol, ss & & ss & & & ac & & fpa (ㅇ), ss, gcol \\
\hline 7 & $\mathrm{ac}$ & ss & gcol, ss & & ss & & & ac & & fpa (q), ss, gcol \\
\hline 8 & $\mathrm{ac}$ & ss & gcol, ss & gco2 & & & tu & $\mathrm{ac}$ & ss & gco1, fpa (†) \\
\hline 9 & & ss & gcol, ss & $\mathrm{gco} 2, \mathrm{ss}$ & & & si & $\mathrm{ac}$ & ss & gcol \\
\hline 10 & gco1, gcol & & ss & tu & & & & & ss $\left(\delta^{\lambda d u j}\right)$ & gco1 \\
\hline 11 & gco1, gco1 & & ss & & $3 x p e\left(0^{1}\right)$ & & ltas $(+)$ & lts & ss & \\
\hline
\end{tabular}

located in between a medial anterior spinoscalid (Ring 02) and a trichoscalid plate. Sectors 3 and 9 have spinoscalids forming double diamonds anterior to a pair of spinoscalids in Ring 7. Sectors 5 and 7 also have spinoscalids forming double diamonds, but anterior to an unpaired, lateral spinoscalid. Sector 6 has spinoscalids arranged as two double diamonds.

The neck has 16 placids, measuring $20 \mu \mathrm{m}$ in length. The midventral placid is broadest, measuring $15 \mu \mathrm{m}$ in width at its base, whereas all other are narrower, measuring $11 \mu \mathrm{m}$ in width at their bases. The trichoscalid plates in the dorsal sectors are composed of a distal part and a slightly broader proximal part, whereas the proximal parts of the ventral trichoscalid plates are much broader. Trichoscalids with trichoscalid plates are present in sectors $2,4,5,7,8$, and 10 .

Segment 1 consists of a complete cuticular ring. Sensory spots are located close to the anterior margin in subdorsal, laterodorsal and sublateral positions (Figs 2B, 4C-D), and slightly more posterior in ventrolateral positions (Figs 2C, 4E); sensory spots are rounded to oval, with numerous micropapillae, two pores, and often a cilium emerging from one of the pores. Glandular cell outlets type 1 present in middorsal and lateroventral positions (Fig. 2B-C). Dorsal and lateral sides, and posterior half of ventral side, densely covered with cuticular hairs emerging through rounded perforation sites (Fig. 4C-D); an anterior W-shaped area on the ventral side is completely devoid of hairs (Fig. 4E). The posterior segment margin is straight around the segment, terminating into a pectinate fringe with very short, uniform fringe tips.

Segment 2 consists of a complete cuticular ring. Pachycyclus of the anterior segment margin is of medium thickness and not interrupted (Fig. 2B-C). Sensory spots are located in middorsal (but slightly laterally displaced), laterodorsal (twin pair) (Figs 2B-C, 4C-D) and ventromedial positions (Fig. 4E); appearance sensory spots on this and all following segments as those on segment 1 , but droplet-shaped. Glandular cell outlets type 1 present in middorsal and ventromedial positions (Fig. 2B-C); and quite well-developed tubes present in lateroventral positions (Figs 2C, 4E). The segment is densely covered with bracteate hairs. The posterior segment margin is nearly straight; pectinate fringe from middorsal to lateroventral positions with short fringe tips, as on segment 1; fringe tips from lateroventral to ventromedial positions conspicuously longer, and then slightly shorter again between ventromedial positions. 
Segment 3, and remaining segments, consisting of one tergal and two sternal plates (Fig. 2C). Pachycyclus of the anterior segment margin of medium thickness, and interrupted only at tergosternal junctions. Sensory spots present in subdorsal, laterodorsal (Fig. 2B) and sublateral positions. Glandular cell outlets type 1 present in middorsal and ventromedial positions. Bracteate cuticular hairs are densely covering the segment from middorsal to ventromedial positions; paraventral parts densely covered by non-bracteate, hair-like extensions, forming a conspicuous shield-shaped area. Pectinate fringe of posterior margin with slightly longer fringe tips on dorsal and lateral sides, compared to those on preceding segment, and conspicuously long tips in lateroventral to ventromedial positions.

Segment 4 with short acicular spine in middorsal position, not reaching the posterior margin of the segment (Fig. 4F); all spines on this segment and until segment 9 with cylindrical proximal part that halfway to the tip begins to taper gradually. Sensory spots present in subdorsal, midlateral (Figs 2D, 4F) and ventromedial positions; midlateral sensory spots considerably smaller than all other sensory spots on the animals (Fig. 4F inset), but they occur consistently in all examined specimens. Glandular cell outlets type 1 present in subdorsal (Fig. 2D) and ventromedial positions. Pectinate fringe of posterior segment margin with long fringe tips from middorsal to ventromedial positions, and then very short again between ventromedial positions. Pachycycli and cuticular hairs as on preceding segment.

Segment 5 with short acicular spine in middorsal position (Fig. 4F), not reaching the posterior margin of the segment, and well-developed tubes in lateroventral positions (Figs 2E, 4H). Sensory spots present in subdorsal, midlateral (Figs 2D, 4F) and ventromedial positions. Glandular cell outlets type 1, pachycycli, pectinate fringe of posterior margin and cuticular hairs as on preceding segment.

Segment 6 with short acicular spines in middorsal and lateroventral positions (Fig. 4F, H); middorsal spine does not reach the posterior margin of the segment, whereas lateroventral spines reach pectinate fringe. Sensory spots present in paradorsal, subdorsal, midlateral (Fig. 4F) and ventromedial (Fig. 4H) positions. Females with female papillae with openings, resembling small glandular cell outlets type 2 (Fig. 4H inset), in ventromedial positions, close to and lateral to sensory spots (Fig. 4H); the intracuticular structures of the papillae are crescentic with a small protuberance in the curved part of each structure (Fig. 2E). Glandular cell outlets type 1, pachycycli, pectinate fringe of posterior margin and cuticular hairs as on preceding segment.

Segment 7 with short acicular spines in middorsal (one specimen with two spines emerging from the same opening) and lateroventral positions (Figs 2D-E, 4F, H); middorsal spine does not reach the posterior margin of the segment, whereas lateroventral spines reach pectinate fringe. Females with female papillae as on segment 6 , but with openings slightly more anterior and lateral to sensory spots (Figs 2E, 4H); the substructure of these papillae differs from those on preceding segment, and forms instead a small intracuticular tube (Fig. 2E). Sensory spots, glandular cell outlets type 1, pachycycli, pectinate fringe of posterior margin and cuticular hairs as on preceding segment.

Segment 8 with short acicular spines in middorsal and lateroventral positions (Figs 2D-E, 4F, H), both reaching the pectinate fringe of the posterior margin of the segment. Tubes are present in lateral accessory positions (Fig. 4G). Minute glandular cell outlets type 2 present in laterodorsal positions, but very close to the midlateral lines (Figs 2D, F, 4G). Sensory spots present in paradorsal, subdorsal, and ventrolateral positions. Females with female papillae with same substructure as those on segment 7, but with openings more anterior and closer to midventral line. Glandular cell outlets type 1, pachycycli, pectinate fringe of posterior margin and cuticular hairs as on preceding segment.

Segment 9 with acicular spines in lateroventral positions (Fig. 4G), just reaching the posterior margin of the segment. Sensory spots present in paradorsal, subdorsal, laterodorsal (posterior to glandular cell outlet type 2), and ventrolateral positions. Glandular cell outlets type 1 and 2 (Figs 2F, 4G) as 

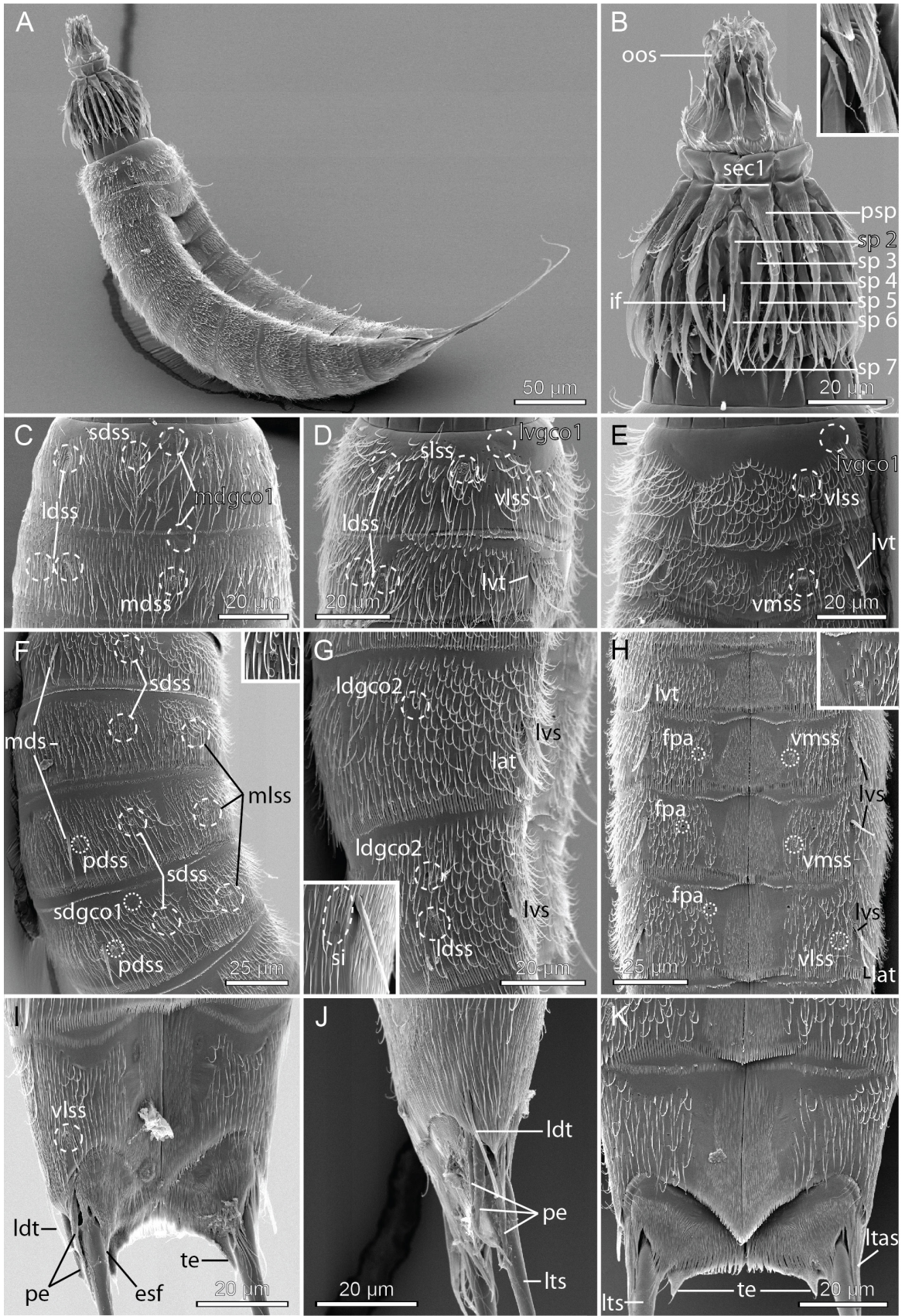

Fig. 4. Scanning electron micrographs showing overviews and details of Echinoderes dujardinii

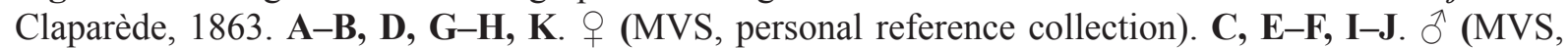
personal reference collection). A. Lateroventral overview. B. Head with mouth cone and introvert, ventral view; inset shows detail of primary spinoscalid fringes attaching along a longitudinal line, and the median basal sheath spike of the Ring 03 spinoscalid. C. Segments 1 to 2, dorsal view. D. Segments 1 to 2, lateral view. E. Segments 1 to 2, ventral view. F. Segments 4 to 7, subdorsal view; inset shows the minute midlateral sensory spot on segment 4 . G. Segments 8 to 9 , lateral view; inset shows detail of sieve plate and lateroventral spine of segment 9 . H. Segments 5 to 8 , ventral view, showing female sexual dimorphism; inset shows detail of glandular cell outlet type 1, sensory spot and female papillae on left sternal plate of segment 6. I. Segments 10 to 11 ventrolateral view, showing male sexual dimorphism. J. Segments 10 to 11 lateral view, showing male sexual dimorphism. K. Segments 10 to 11 ventral view, showing female sexual dimorphism. 
on preceding segment, but female papillae not present. Paired nephridiopore areas each consists of a small, rounded sieve plate anterior to a single pore that we consider to be part of the nephridial system, present in lateral accessory positions (Fig. 4G, inset). Pectinate fringe of posterior segment margin with uniformly long fringe tips around the segment. Pachycycli and cuticular hairs as on preceding segment.

Segment 10 with well-developed laterodorsal tubes near posterior segment margin (Figs 2G-H, 4IJ). Sensory spots present in subdorsal (but very close to paradorsal) positions; males furthermore with sensory spots in ventrolateral positions (Fig. 4I). Glandular cell outlets type 1 present as two longitudinally arranged middorsal ones and in ventromedial positions. The posterior segment margin of the tergal plate is straight, whereas margins of sternal plates are deeply concave (Fig. 4K); fringe tips of pectinate fringe are considerably shorter than those on preceding segments. Pachycycli and cuticular hairs as on preceding segment.

Segment 11 with lateral terminal spines (Fig. 2A, G). Males with three pairs of penile spines (Figs 2G, 4I-J); all three penile spines resemble each other, with thicker and rigid proximal parts that taper towards more flexible, distal tips; median penile spines slightly thicker than dorsal and ventral ones. Females with short, thin lateral terminal accessory spines (Figs $2 \mathrm{H}, 4 \mathrm{~K}$ ). Sensory spots present in subdorsal and ventrolateral positions. Glandular cell outlets type 1 present as two longitudinally arranged middorsal ones. The dorsal and most of the ventral side of the segment are densely covered with non-bracteate hair-like extensions. Tergal extensions are well-spaced, short and pointed (Figs 2G-H, 4I, K); sternal extensions short, with ventrolateral seta-like tuft of extended fringe tips (Figs 2H, 4I).

Echinoderes ehlersi Zelinka, 1913

Table 5

Echinoderes ehlersi Zelinka, 1913: 419-424, pl. 39, figs 6-9.

Echinoderes ehlersi-Zelinka 1928: 237-240, fig. 41.

Non Echinoderes ehlersi - Higgins \& Rao 1979: 79-82, fig. 2.

\section{Description}

The species was collected and described from Zanzibar, Tanzania, at the African east coast. No type or topotype specimens were available for the present study. The species has not been collected since its description, hence, the present notes are a summary of taxonomically relevant information extracted from Zelinka $(1913,1928)$.

Small Echinoderes, with a trunk length of $228 \mu \mathrm{m}$, and lateral terminal spines reaching $3 / 4$ of trunk length. Very short middorsal spines present on segments 4 to 8 , not even reaching the pectinate fringes of posterior segment margins, and lateroventral spines on segments 6 to 9 . Tubes present in lateroventral positions on segments 2 and 5, and in laterodorsal positions on 10. The presence of glandular cell outlets type 2 in laterodorsal positions on segments 8 and/or 9 are not mentioned in the description, but they could possibly be present. Tergal extensions of segment are 11 short, pointed and well-spaced, and sternal extensions rounded, with ventrolateral seta-like tuft of extended fringe tips. Females with lateral terminal accessory spines. The presence of ventromedial female papillae is not mentioned in the description, but they could possibly be present in ventromedial or ventrolateral positions on some sternal plates. 
Table 5. Measurements extracted from Zelinka (1913) of female holotype of Echinoderes ehlersi Zelinka, 1913 from Zanzibar, Tanzania (in $\mu \mathrm{m}$ ).

\begin{tabular}{lc}
\hline Character & Holotype \\
\hline & \\
TL & 228 \\
MSW-8 & 59.0 \\
MSW-8/TL & $25.9 \%$ \\
SW-10 & 47.5 \\
SW-10/TL & $20.0 \%$ \\
S1 & 24.7 \\
S2 & 21.1 \\
S9 & 24.6 \\
S10 & 28.2 \\
& \\
MD4 (ac) & 8.4 \\
MD5 (ac) & 9.6 \\
MD6 (ac) & 10.8 \\
MD7 (ac) & 12.0 \\
MD8 (ac) & 14.0 \\
LV5 (tu) & \\
LV6 (ac) & 12.2 \\
LV7 (ac) & 14.3 \\
LV8 (ac) & 16.0 \\
LV9 (ac) & 17.2 \\
LD10 (tu) & 11.9 \\
LTS & 19.3 \\
LTS/TL & \\
LTAS & 176.0 \\
& $77.2 \%$ \\
& 43.0 \\
\hline
\end{tabular}

Echinoderes gerardi Higgins, 1978

Figs 5-6, Tables 4, 6

Echinoderes gerardi Higgins, 1978: 172-176, figs 1-8.

Echinoderes gerardi - Dal Zotto \& Todaro 2016: 132-134, 138, table 6.

E. dujardinii - Mari \& Morselli 1987: 117. — Sánchez-Tocino et al. 2011: 179-184, figs 1-4, tables 1-2. - Sánchez et al. 2012: 26 [Algeciras, Granada, Murcia, Alicante]. — Ürkmez et al. 2016: 1-8, figs $2-4$.

Echinoderes aff. gerardi - Sönmez et al. 2016: 8-9, figs 1-2. 


\section{Emended diagnosis}

Echinoderes with very short middorsal spines on segments 4 to 8 not even reaching the pectinate fringes of posterior segment margins; middorsal spines on segments 4 to 7 lanceolate, i.e., narrower proximally and distally than medially, whereas middorsal spine on segment 8 is more parallel-sided and only narrowing distally. Lateroventral spines on segments 6 to 9. Tubes present in lateroventral positions on segments 2 and 5 , in lateral accessory positions on segment 8 , and in laterodorsal positions on 10 . Minute glandular cell outlets type 2 in laterodorsal positions on segments 8 and 9; outlets on segment 9 anterior to laterodorsal sensory spots. Tergal extensions of segment 11 short, pointed and well-spaced; sternal extensions short, with ventrolateral seta-like tuft of extended fringe tips. Females with ventromedial female papillae resembling glandular cell outlets type 2 on segments 6 to 8 .

\section{Material examined}

\section{Holotype}

TUNISIA • 1 +; Gulf of Tunis, Korbous; $36^{\circ} 49^{\prime}$ N, $010^{\circ} 34^{\prime}$ E; 0 m b.s.l.; Dr K. Ruetzler leg.; choanocytes of the sponge Tethya aurantium (see Higgins 1978); USNM-54841. Specimen mounted for LM.

\section{Additional material}

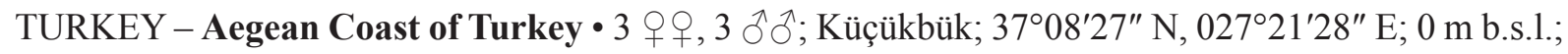
23 Oct. 2012; Sönmez and S. Sak leg.; intertidal macroalgae; NHMD-616808 to $616813 \bullet 4$ 우, 1 o; Akbük Sonras1; 37²3'59" N, 027 22'10" E; 0 m b.s.l.; 24 Oct. 2012; Sönmez and S. Sak leg.; intertidal macroalgae; NHMD-616814 to 616818 - 1 क; Öncesi; $37^{\circ} 59^{\prime} 40^{\prime \prime}$ N, $027^{\circ} 07^{\prime} 15^{\prime \prime}$ E; 0 m b.s.l.; 25 Oct. 2012; Sönmez and S. Sak leg.; intertidal macroalgae; NHMD-616819 • 1 o, 1 ô;; Çalış; 36³9'33" N, 029 $06^{\prime} 35^{\prime \prime}$ E; 0 m b.s.1.; 16 May 2012; Sönmez and S. Sak leg.; intertidal sand from type locality of Cephalorhyncha flosculosa Yildiz et al., 2016 (see Yildiz et al. 2016); NHMD-616820 to 616821 • 3 우,

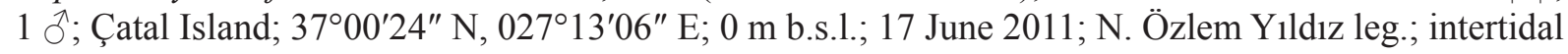

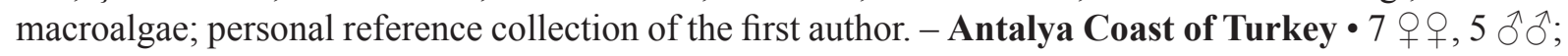
Antalya, Bilem Beach; 36 51'17" N, 03044'38" E; 3 m b.s.1.; 20 Oct. 2012; F. Durucan leg.; red algae (Laurencia obtusa) on sandy bottom at type locality of Echinoderes antalyaensis Yamasaki \& Durucan, 2018 (see Yamasaki \& Durucan 2018); personal reference collection of the last author.

SPAIN - Andalusian Atlantic south coast of Spain • 2 q, 1 ㄱ; Cadiz; F. Pardos leg.; UCM • 2 우, $1 \mathrm{O}$; slightly west of the Gibraltar Strait, Algeciras; F. Pardos leg.; UCM. - Spanish Territory on African mainland at the Gibraltar Strait • 3 우, 3 $\partial^{\lambda}$; Ceuta; F. Pardos leg.; UCM. - Andalusian Mediterranean south coast of Spain • 1 q; Málaga; F. Pardos leg.; UCM • 1 q; Almería; F. Pardos leg.; UCM. - Murcian Mediterranean southeast coast of Spain • 1 ㅇ, 2 $\widehat{\jmath}$; Cabo de Palos; F. Pardos leg.; UCM. - Valencian Mediterranean east coast of Spain • 1 § ; Denia; F. Pardos leg.; UCM.

All Spanish and Turkish Aegean specimens mounted for LM; all Turkish specimens from Antalya mounted for SEM. See Table 1 for an overview.

\section{Description}

Measurements of spine and segments length and dimensions were made on the Turkish and Spanish specimens. They are presented separately and summarized together with the original measurements of the type material in Table 6. LM and SEM examinations of E. gerardi revealed that it is morphologically very similar with $E$. dujardinii. Positions of cuticular structures, i.e., spines, tubes, most sensory spots and glandular cell outlets (Figs 5A-H, 6A-F, I-K) followed the pattern observed in E. dujardinii, hence, the distribution of these structures is summarized in the same table (see Table 4). The only observed difference in distribution of sensory spots regarded the ventrolateral sensory spots on segment 10 , that in E. dujardinii are restricted to males, but occur in both sexes in E. gerardi (Fig. 6J-K). Since the 

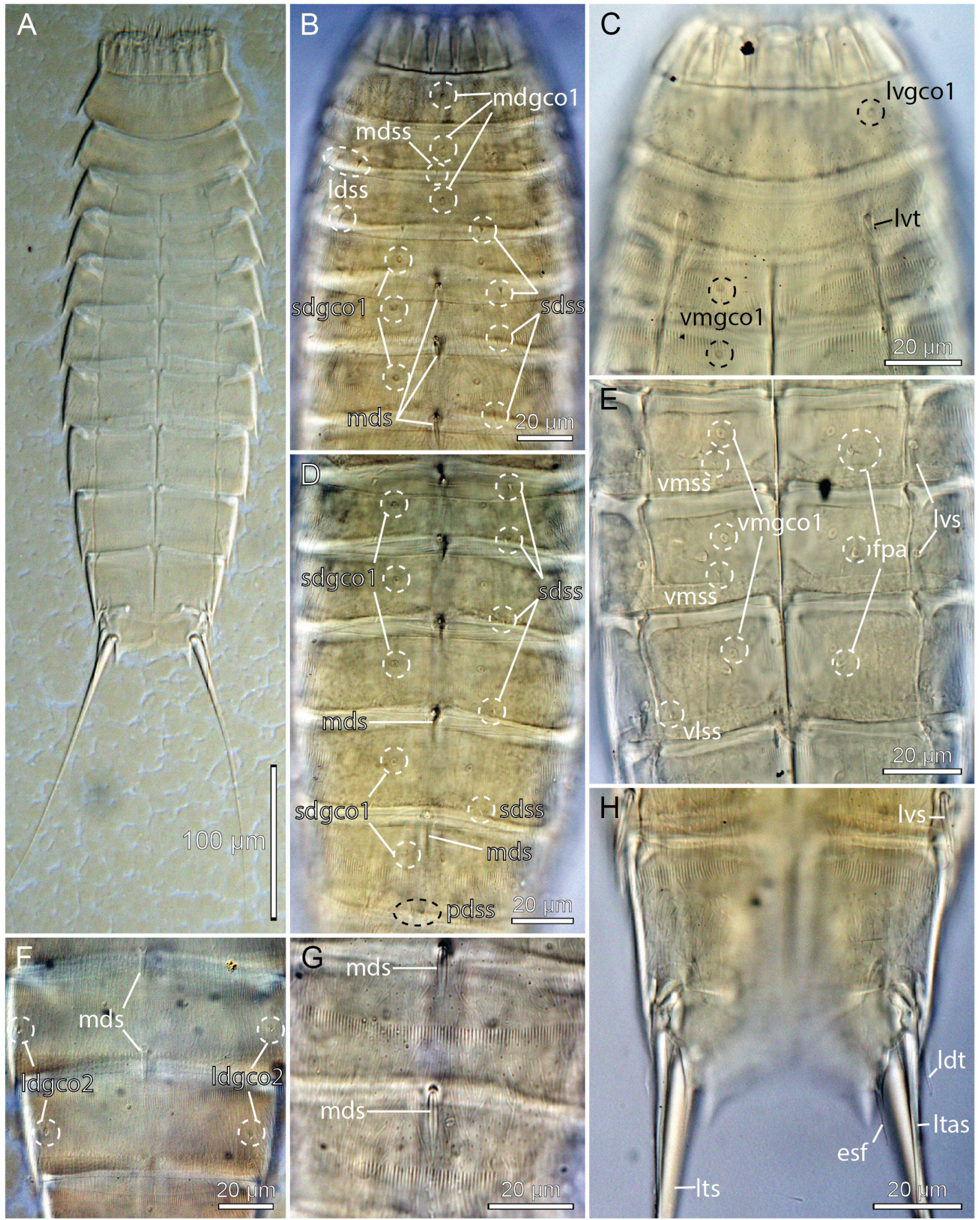

Fig. 5. Light micrographs showing overviews and details of of Echinoderes gerardi Higgins, 1978. A, F. Holotype, $q$ (USNM-54841). B-E, G-H. $q$, non-type from Turkey (NHMD-616810). A. Ventral overview. B. Segments 1 to 6, dorsal view. C. Segments 1 to 4, ventral view. D. Segments 5 to 9, dorsal view. E. Segments 6 to 8, ventral view, showing female sexual dimorphism. F. Segments 8 to 9, dorsal view. G. Detail of segments 7 to 8 showing middorsal spines. H. Segments 10 to 11 , ventral view, showing female sexual dimorphism. 

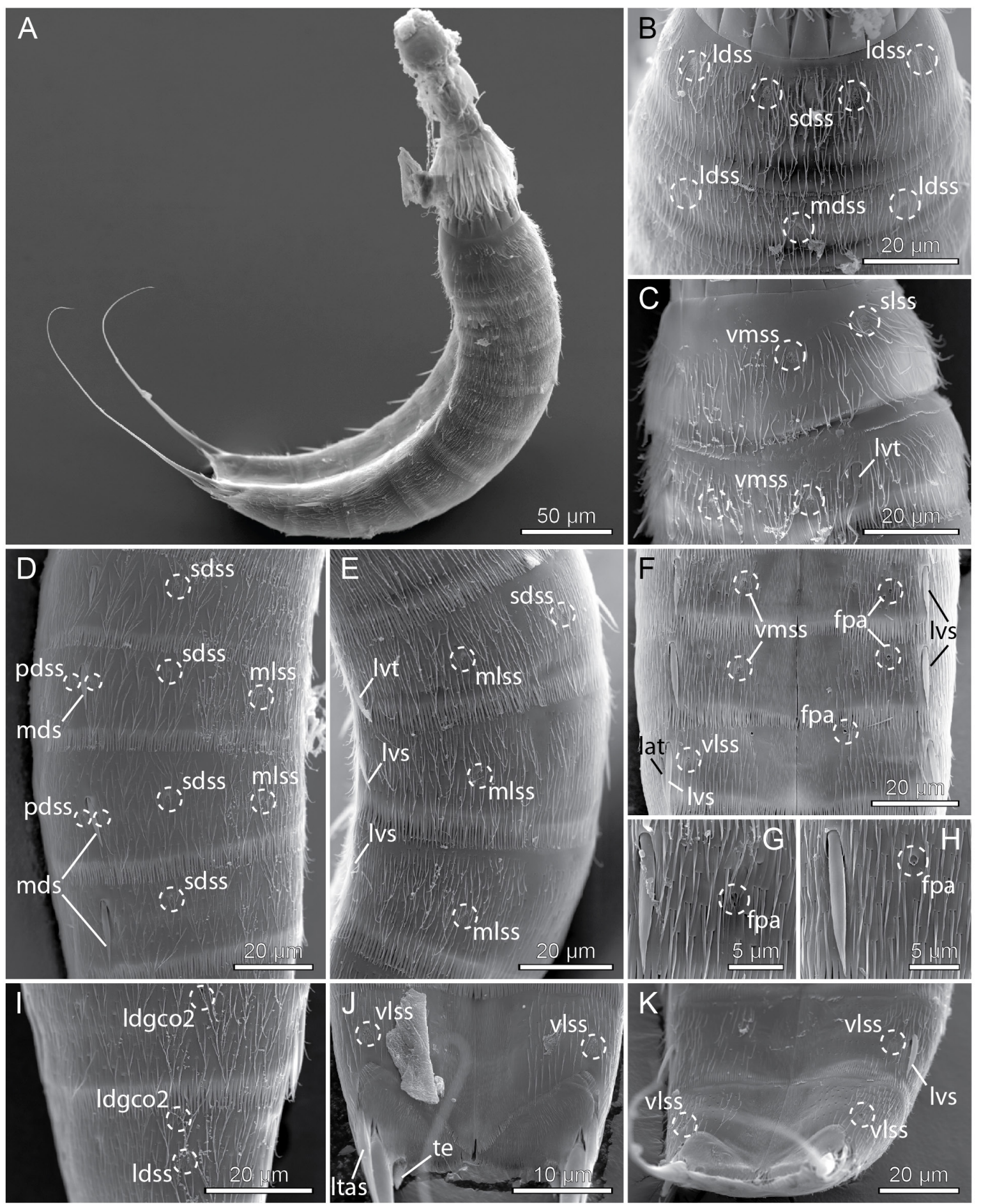

Fig. 6. Scanning electron micrographs showing overviews and details of Echinoderes gerardi Higgins, 1978. A-C, E, K. ô (HY, personal reference collection). D, F-J. o (HY, personal reference collection). A. Lateral overview. B. Segments 1 to 2, dorsal view. C. Segments 1 to 2, ventrolateral view. D. Segments 5 to 8, subdorsal view. E. Segments 5 to 7, lateral view. F. Segments 6 to 8, showing female sexual dimorphism. G. Detail of segment 6 showing lateroventral spine and female papilla. H. Detail of segment 7 showing lateroventral spine and female papilla. I. Segments 8 to 9 lateral view. J. Segments 10 to 11 ventral view, showing female sexual dimorphism. K. Segments 9 to 11 ventral view, showing male sexual dimorphism. 


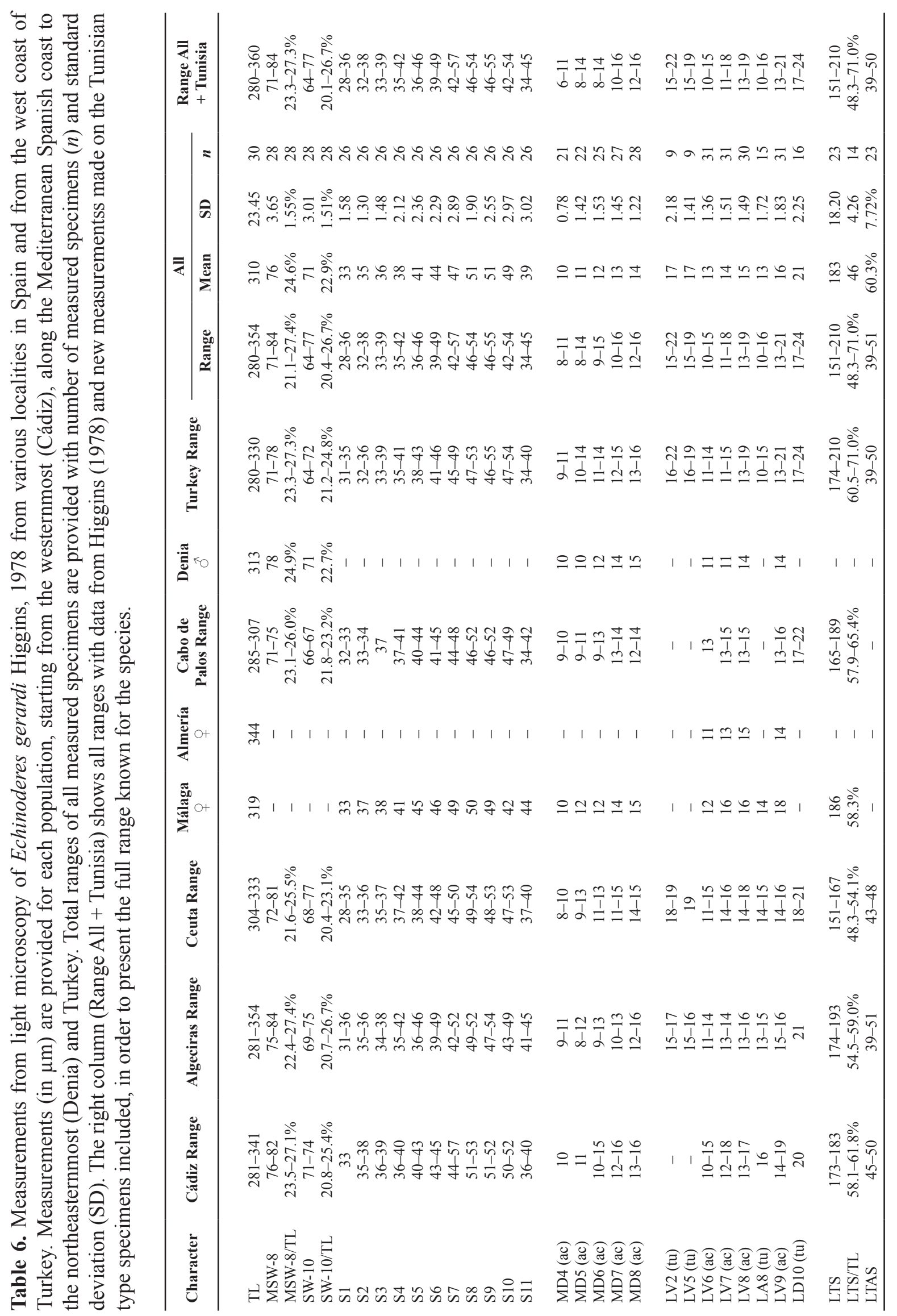


The middorsal spines in E. gerardi are extremely short, and never even reaching the pectinate fringes of the posterior segment margins (Figs 5B-D, F-G, 6D). Opposite to typical acicular spines, the middorsal spines in E. gerardi are tapered at their attachment point, broadest around $1 / 3$ from proximal end, and then gradually tapering from this point towards the tip, giving them a lanceolate appearance (Figs $5 \mathrm{~F}-\mathrm{G}$, 6D). Female papillae are present on sternal plates of segments 6,7 and 8 (Figs $5 \mathrm{E}, 6 \mathrm{~F}-\mathrm{H}$ ), and have the same intracuticular structure as described from E. dujardinii. However, while the position of the papillae in $E$. dujardinii appeared to be rather fixed within the centre of the ventromedial area, the position on segment 6 in $E$. gerardi varied from centred ventromedial to a much more lateral position, very close to the ventrolateral line. But other than this, the morphology is very similar with the one in E. dujardinii, including the presence of laterodorsal glandular cell outlets type 2 on segments 8 and 9 (Figs 5F, 6I). The only other differences are meristic (see Tables 3 and 6, and Discussion).

Echinoderes gizoensis Thormar \& Sørensen, 2010

\section{Material examined}

Holotype

SOLOMON ISLANDS • 1 क; Ghizo Island, Grand Central Station diving locality; $08^{\circ} 00^{\prime} 49^{\prime \prime}$ S, 156 45'26" E; 14 m b.s.l.; 4 Jan. 2007; J. Thormar leg.; coral sand; NHMD-099742. Specimen mounted for LM.

\section{Paratypes}

SOLOMON ISLANDS -1 q, 1 ; ; same collection data as for holotype; NHMD-099743 to 099744. Specimens mounted for SEM. See Table 1 for an overview.

\section{Description}

All details followed the original description by Thormar \& Sørensen (2010), hence, we would only address two additional points. First of all, we can confirm the absence of glandular cell outlets type 2 in this species. Secondly, we can confirm the presence of female papillae in ventromedial positions on segment 7. They consist of circular openings, and quite broad, sort of rhomboid tubular intracuticular substructures. Tergal extensions of segment 11 are pointed, and extending into long, flexible seta-like tips, formed by a terminal fringe. Sternal extensions are rounded, without any particular fringe differentiation.

Echinoderes imperforatus Higgins, 1983

Fig. 7

\section{Emended diagnosis}

Echinoderes with short middorsal spines on segments 4 to 8 , and lateroventral spines on segments 6 to 9 , never extending beyond the posterior margin of their respective segments. Tubes present in lateroventral positions on segments 2 and 5, and in laterodorsal positions on 10. Minute glandular cell outlets type 2 in laterodorsal positions on segments 8 and 9 . Tergal extensions of segment 11 short, pointed and well-spaced; sternal extensions short with ventrolateral seta-like tuft of extended fringe tips. Females with ventromedial female papillae resembling glandular cell outlets type 2 on segments 6 to 8 . Trunk segments with cuticular hairs, but perforation sites are indistinct.

\section{Material examined}

Holotype

BELIZE • 1 क; Carrie Bow Cay; $16^{\circ} 50^{\prime}$ N, 08806’ W; 14 m b.s.1.; 8 Apr. 1977; R.P. Higgins leg.; RH442, fine coral sand with mangrove and seagrass detritus; USNM-69972. Specimen mounted for LM. 

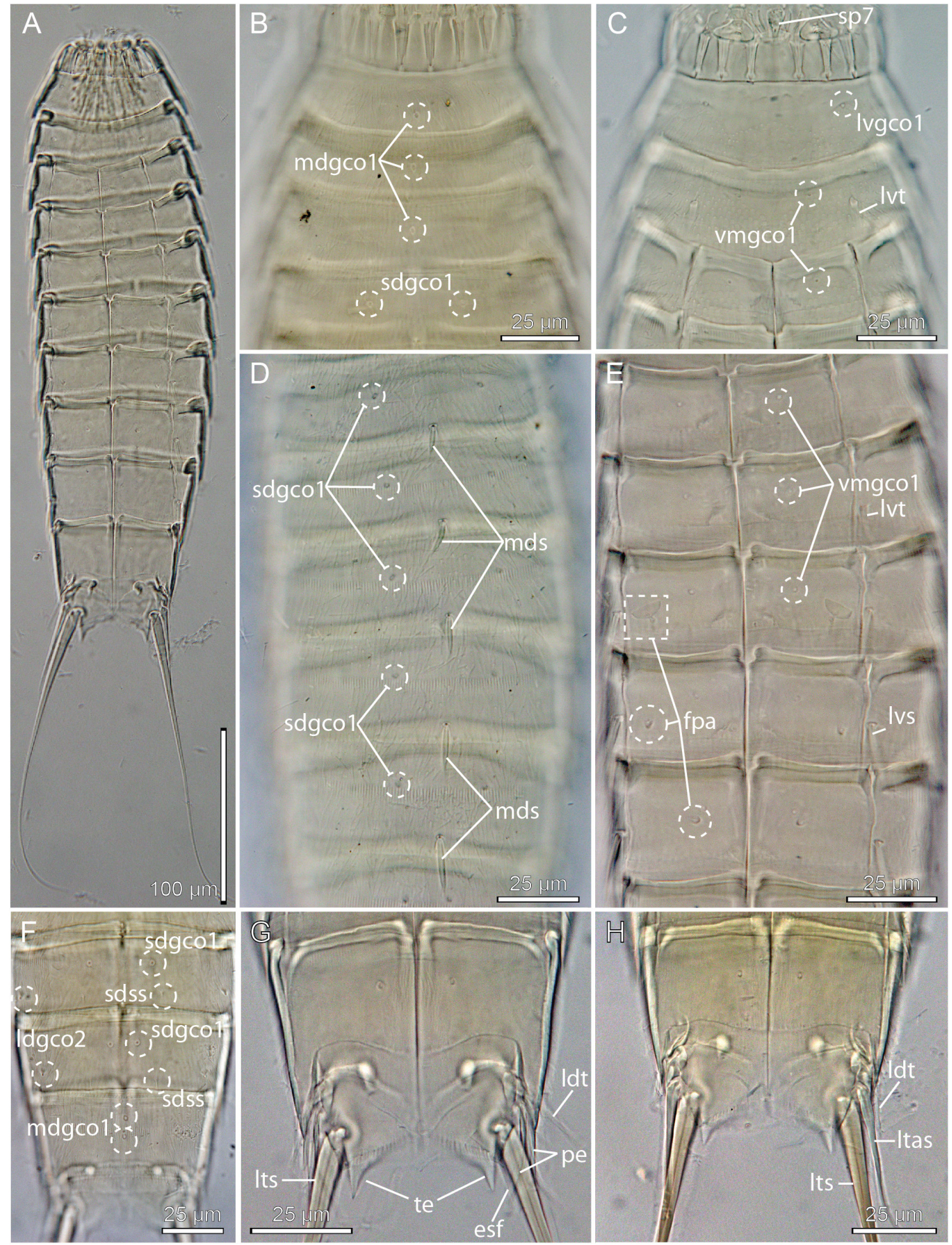

Fig. 7. Light micrographs showing overviews and details of Echinoderes imperforatus Higgins, 1983. A, D-E. Holotype, o (USNM-69972). B, F, H. Paratype, $q$ (USNM-69974). C, G. Paratype, ${ }^{\Uparrow}$ (USNM-69975). A. Ventral overview. B. Segments 1 to 3, dorsal view. C. Segments 1 to 3, ventral view. D. Segments 4 to 8, dorsal view. E. Segments 4 to 8, ventral view, showing female sexual dimorphism. F. Segments 8 to 10, dorsal view. G. Segments 10 to 11, ventral view, showing male sexual dimorphism. H. Segments 10 to 11, ventral view, showing female sexual dimorphism. 


\section{Paratypes}

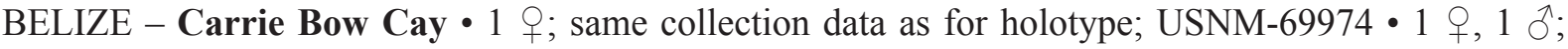
500 m southwest of type locality; 3 m b.s.1.; 8 Apr. 1977; R.P. Higgins leg.; RH443, coralline mud with mangrove and seagrass detritus; USNM-69975 • 1 क ; 500 m south of RH443; 3 m b.s.1.; 8 Apr. 1977; R.P. Higgins leg.; RH444, very fine coralline mud with mangrove and seagrass detritus; USNM-69976.

All specimens mounted for LM. See Table 1 for an overview.

\section{Description}

The appearance of the species generally follows the description provided by Higgins (1983), hence the following notes only provide additional information not included in the original description.

Introvert with six trichoscalids attached to trichoscalid plates (four dorsal and two ventral). Tubes present in lateroventral positions on segments 2 and 5 (Fig. 7C, E), and in laterodorsal positions on segment 10 (Fig. 7G-H). Spines are present in middorsal positions on segments 4 to 8 (Fig. 7D), and lateroventral positions on segments 6 to 9 (Fig. 7E); spines never extend beyond the posterior margins of their respective segments. Sensory spots could not be observed on all segments, but it is positively confirmed that sensory spots are present in following positions: paradorsal positions on segments 6 to 8 , subdorsal positions on segments 4 to 9 (Fig. 7F), and ventromedial positions on segment 1. Glandular cell outlets type 1 are present in following positions: middorsal position on segments 1 to 3 (Fig. 7B), subdorsal positions on segments 4 to 9 (closer to paradorsal positions on segment 9) (Fig. 7B, D, F), lateroventral positions on segment 1 (Fig. 7C), and ventromedial positions on segments 2 to 10 (Fig. 7C, E). Minute glandular cell outlets type 2 present in laterodorsal positions on segments 8 and 9 (Fig. 7F). Females with ventromedial female papillae in ventromedial positions on segments 6 to 8 (Fig. 7E); outlet of papillae on segments 6 and 7 close to the ventrolateral positions, whereas outlets on segment 8 are closer to the midventral line. The intracuticular structures of the papillae on segment 6 form a semicircle with a small protuberance in the curved part of the structure; substructure of segment 7 and 8 papillae forms very short intracuticular tubes. Tergal extensions triangular and well-spaced (Fig. 7G-H). Posterior margins of sternal plates of terminal segment obliquely straight towards a ventrolateral point; pectinate fringe well-developed, with differentiated fringe tips forming seta-like extensions (Fig. 7G). Perforation sites of cuticular hairs are not invisible on most segments, however, they can be visualized as indistinct dots on segments 1 and 2.

Echinoderes kozloffi Higgins, 1977

Fig. $8 \mathrm{~B}, \mathrm{E}, \mathrm{H}$

\section{Material examined}

\section{Holotype}

WASHINGTON STATE 1 đo; San Juan Island, North Bay, Argyle Lagoon; $48^{\circ} 31^{\prime} \mathrm{N}, 123^{\circ} 01^{\prime} \mathrm{W} ; 1 \mathrm{~m}$ b.s.1.; 9 Aug. 1975; E. Kozloff leg.; muddy sand gravel, rich in organic matter; USNM-53337. Specimen mounted for LM.

\section{Paratypes}

WASHINGTON STATE $\bullet 4$ 우, 1 ¿ ; same collection data as for holotype; USNM-53339. Specimen mounted for LM.

The description by Higgins (1977a) does not state clearly from which habitat the type material was collected, but sampling was done by E. Kozloff who probably collected the species from muddy sand gravel, rich in organic matter (Kozloff 1972). 

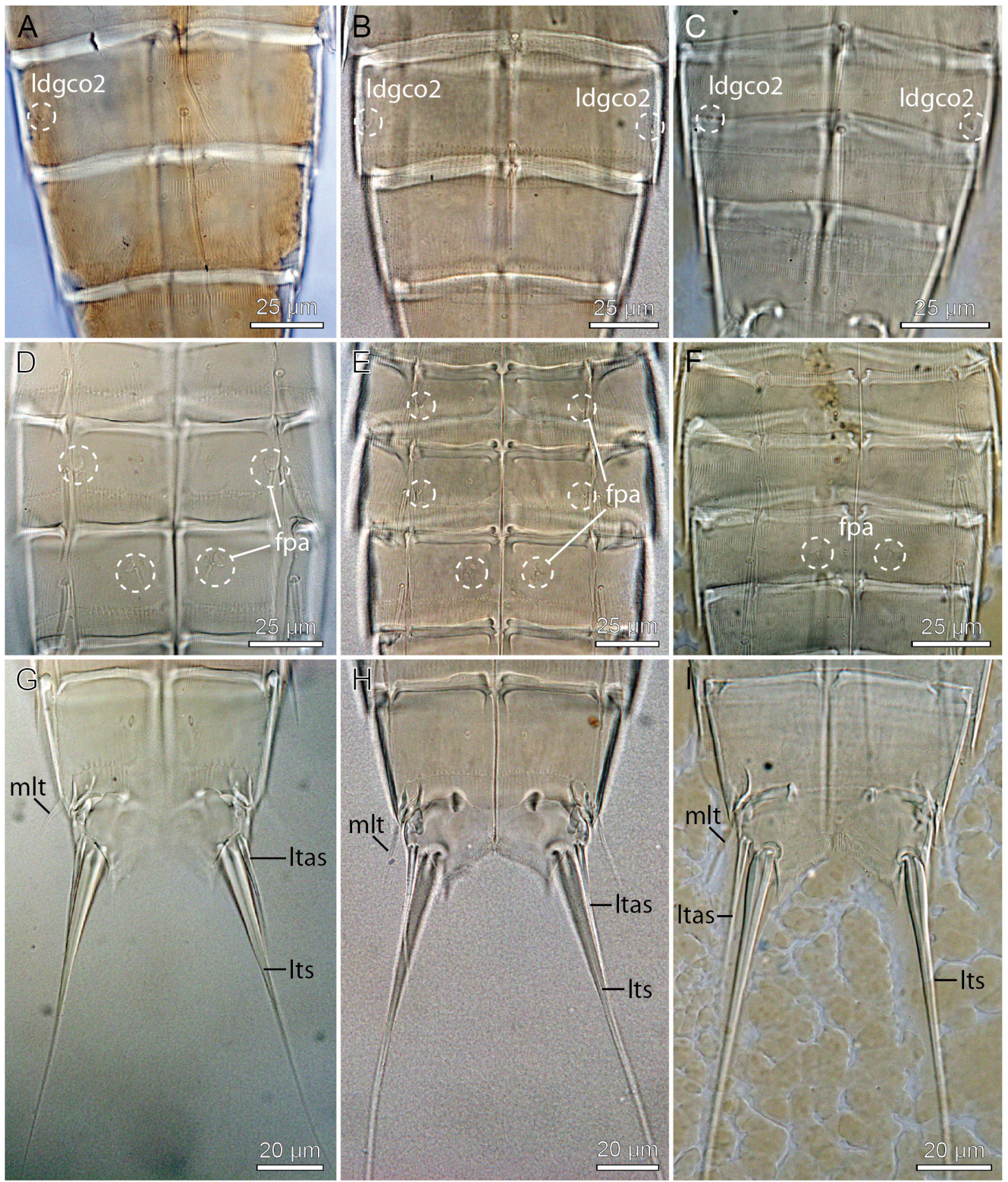

Fig. 8. Comparative light micrographs showing selected details of E. pacificus Schmidt, 1974. A. Holotype, + (USNM-53335). D-G. Paratype (USNM-53336). B, E, H. E. kozloffi Higgins, 1977. Holotype, $q$ (USNM-53337). C, F, I. E. sublicarum Higgins, 1977. Paratype, $q$ (USNM-54399). A-C. Segments 8 to 9, dorsal view, showing presence of glandular cell outlets type 2 on segment 8 . D-F. Segments 6 to 8, ventral view, position and appearance of sexually dimorphic female papillae. G-I. Segments 10 to 11, with midlateral tubes on segment 10, and lateral terminal spines. 
Additional material

CANADA - British Columbia • 2 q $q, 1$ ơ; Vancouver Island, Clover Point; 4824'14" N, $123^{\circ} 21^{\prime} 04^{\prime \prime}$ W; 0 m b.s.l.; May 2015; M. Herranz leg.; intertidal brown algae (see Herranz \& Leander 2016); NHMD100304 to 100305 and NHMD-616637 • 1 क; Archaeology Beach; 51 $39^{\prime} 52^{\prime \prime} \mathrm{N}, 128^{\circ} 05^{\prime} 50^{\prime \prime} \mathrm{W} ; 0 \mathrm{~m}$ b.s.1.; July 2015; M. Herranz leg.; intertidal brown algae (see Herranz \& Leander 2016); NHMD-100306.

All specimens mounted for LM. Numerous additional specimens from the same localities, mounted for LM and SEM, are stored in Herranz' personal reference collection. See Table 1 for an overview.

\section{Description}

The species was recently redescribed by Herranz \& Leander (2016), and the specimens follow this rather accurate description. The only details that should be added regard the intracuticular substructures related to the female papillae on segments 6 to 8 , and middorsal spine length. Female papillae are present in ventrolateral positions on segments 6 and 7 (Fig. 8E), and they have a short, somewhat rhomboid intracuticular tube leading to the rounded outlet. Female papillae on segment 8 are ventromedial (Fig. 8E), and the intracuticular substructures are crescentic with a small protuberance in the curved part of the structure. Middorsal spine of segment 8 extends well onto segment 9, but never reaches posterior margin of segment (Fig. 8B). It was furthermore confirmed that laterodorsal glandular cell outlets type 2 are present on segment 8 only (Fig. 8B).

Echinoderes pacificus Schmidt, 1974

Fig. 8A, D, G; Tables 7-8

\section{Emended diagnosis}

Echinoderes with middorsal spines on segments 4 to 8 , and lateroventral spines on segments 6 to 9; middorsal spines on segments 5 to 8 extend well beyond the posterior margin of their respective segments. Tubes present in lateroventral positions on segments 2 and 5, and in midlateral positions on 10; tubes on segment 10 short and stout. Minute glandular cell outlets type 2 in laterodorsal positions on segment 8 . Tergal extensions of segment 11 triangular, pointed, well-spaced. Females with female papillae with crescentic and tubular substructure in ventrolateral positions on segment 7 and ventromedial on segment 8 . Lateral terminal spines thick in proximal $1 / 3$, but tapered abruptly into very thin distal $2 / 3$.

\section{Material examined}

Holotype

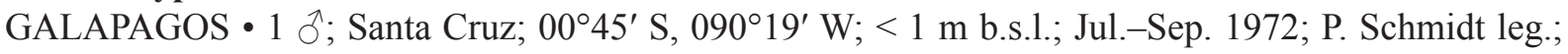
heterogeneous sediment, rich in organic matter; USNM-53335. Specimen mounted for LM.

\section{Paratypes}

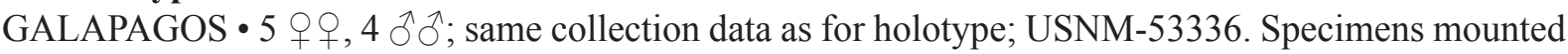
for LM.

Most of the paratypes were in surprisingly good condition, whereas the mounting medium around the holotype was dried out. SEM specimens were not available. See Table 1 for an overview.

\section{Description}

The appearance of the species generally follows the original description by Schmidt (1974), and in particular the redescription by Higgins (1977a), hence the following notes only provide additional information not included in the two previous descriptions. For complete overview of measurements and dimensions, see Table 7. Distribution of cuticular structures, i.e., sensory spots, glandular cell outlets, spines and tubes, is summarized in Table 8. 
Table 7. Measurements from light microscopy for holotype and nine paratypes of Echinoderes pacificus Schmidt, 1974 from Galapagos Islands (in $\mu \mathrm{m}$ ), including number of measured specimens $(n)$ and standard deviation (SD).

\begin{tabular}{|c|c|c|c|c|}
\hline Character & $n$ & Range & Mean & SD \\
\hline $\mathrm{TL}$ & 10 & $359-393$ & 378 & 10.46 \\
\hline MSW-8 & 10 & $69-75$ & 73 & 2.31 \\
\hline MSW-8/TL & 10 & $18.7-20.1 \%$ & $19.3 \%$ & $0.44 \%$ \\
\hline SW-10 & 10 & $64-72$ & 68 & $2.16 \%$ \\
\hline SW-10/TL & 10 & $17.7-18.7 \%$ & $18.1 \%$ & $0.34 \%$ \\
\hline $\mathrm{S} 1$ & 10 & $35-39$ & 37 & 1.41 \\
\hline $\mathrm{S} 2$ & 10 & $32-39$ & 35 & 2.18 \\
\hline $\mathrm{S} 3$ & 10 & $33-41$ & 38 & 2.28 \\
\hline S4 & 10 & $38-43$ & 40 & 1.75 \\
\hline S5 & 10 & $40-46$ & 43 & 2.16 \\
\hline S6 & 10 & $43-50$ & 45 & 2.45 \\
\hline S7 & 10 & $45-52$ & 48 & 2.42 \\
\hline S8 & 10 & $48-53$ & 52 & 1.55 \\
\hline S9 & 10 & $50-59$ & 53 & 2.81 \\
\hline $\mathrm{S} 10$ & 10 & $46-54$ & 49 & 2.82 \\
\hline S11 & 10 & $34-39$ & 36 & 1.93 \\
\hline MD4 (ac) & 9 & $27-33$ & 28 & 1.94 \\
\hline MD5 (ac) & 7 & $31-44$ & 35 & 4.50 \\
\hline MD6 (ac) & 8 & $41-54$ & 51 & 4.21 \\
\hline MD7 (ac) & 9 & $56-71$ & 65 & 5.30 \\
\hline MD8 (ac) & 9 & $77-89$ & 83 & 4.43 \\
\hline LV2 (tu) & 10 & $16-23$ & 19 & 2.21 \\
\hline LV5 (tu) & 9 & $17-21$ & 18 & 1.20 \\
\hline LV6 (ac) & 10 & $19-27$ & 25 & 2.36 \\
\hline LV7 (ac) & 10 & $27-34$ & 31 & 2.13 \\
\hline LV8 (ac) & 10 & $31-38$ & 36 & 2.08 \\
\hline LV9 (ac) & 9 & $35-43$ & 38 & 2.50 \\
\hline ML10 (tu) & 10 & $12-17$ & 14 & 1.97 \\
\hline LTS & 10 & $96-130$ & 108 & 9.38 \\
\hline LTS/TL & 10 & $26.5-33.5 \%$ & $28.5 \%$ & $2.23 \%$ \\
\hline LTAS & 5 & $36-40$ & 37 & 1.67 \\
\hline
\end{tabular}


Table 8. Summary of nature and location of sensory spots, glandular cell outlets, tubes and spines arranged by series in Echinoderes pacificus Schmidt, 1974. Note that mapping of sensory spots might be incomplete.

\begin{tabular}{|c|c|c|c|c|c|c|c|c|c|c|}
\hline $\begin{array}{c}\text { Position } \\
\text { Segment }\end{array}$ & MD & PD & SD & LD & ML & SL & LA & $\mathbf{L V}$ & $\mathbf{V L}$ & VM \\
\hline 1 & gco1 & & ss & Ss & & gcol & & & & ss \\
\hline 2 & gcol, ss & & & ss,ss & & & & tu & & ss, gco1 \\
\hline 3 & gcol & & & Ss & & ss & & & & gco 1 \\
\hline 4 & $\mathrm{ac}$ & & gcol, ss & & ss & & & & & ss, gco1 \\
\hline 5 & $\mathrm{ac}$ & & gco1, ss & & ss & & & tu & & ss, gcol \\
\hline 6 & $\mathrm{ac}$ & ss & gco1, ss & & ss & & & $\mathrm{ac}$ & & ss,gco1 \\
\hline 7 & $\mathrm{ac}$ & ss & gco1, ss & & ss & & & $\mathrm{ac}$ & fpa ( $(+)$ & ss,gco1 \\
\hline 8 & $\mathrm{ac}$ & ss & gco1, ss & gco2 & ss & & & $\mathrm{ac}$ & ss & gcol, fpa $(+)$ \\
\hline 9 & & ss & gco1, ss & & ss & & si & $\mathrm{ac}$ & Ss & gco1 \\
\hline 10 & gco1, gcol & & ss & & tu & & & & ss & gcol \\
\hline 11 & gco1, gco1 & & ss & & $3 x p e(ð)$ & & ltas (P) & lts & & \\
\hline
\end{tabular}

Spines and tubes are as described by Higgins (1977a), and middorsal spines on segments 5 to 8 extend well beyond the posterior margins of segments from which they originate (Fig. 8A). The line art illustrations provided with the redescription also summarize and show the distribution of glandular cell outlets type 1 correctly (white open circles in Higgins 1977a: figs 26-27), even though the nature of these structures are misinterpreted, mostly as sensory spots in the text. Same illustrations also picture laterodorsal glandular cell outlets type 2 on segment 8 , and female papillae with a crescentic substructure in ventrolateral positions on segment 7 and ventromedial positions on segment 8 . Our observations confirm the presence of these structures (Fig. 8D). The substructure of the female papillae is crescentic, as reported by Higgins (1977a), and in addition they also have a relatively strong tubular substructure.

Higgins (1977a) furthermore noted the short, curved midlateral tubes on segment 10 (described as "lateral spine of segment 12", following the old terminology). We can confirm the distinct appearance of these tubes, and add that they, besides being curved, are conspicuously short and stout, and somewhat truncate (Fig. 8G), which make them differ from segment 10 tubes in other species examined for the present study. Another highly characteristic feature regards the shape of the lateral terminal spines. The proximal parts of the spines are conspicuously thick, or swollen, but around $1 / 3$ from the proximal end the spines taper abruptly, and become very thin and nearly seta-like (Fig. 8G). Tergal extensions are triangular and well-spaced; sternal extensions are short with ventrolateral seta-like tuft of extended fringe tips.

Echinoderes pilosus Lang, 1949

Figs 9-10; Tables 9-10

\section{Emended diagnosis}

Echinoderes with middorsal spines on segments 4 to 8, and lateroventral spines on segments 6 to 9; all middorsal spines slender and flexible and projecting well beyond the posterior margin of their respective segments. Long and slender tubes present in ventrolateral positions on segment 2, lateroventral positions 
on segment 5, and in laterodorsal positions on 10. Incomplete midventral, intracuticular fissure present on anterior half of segment 2. Two middorsal, longitudinally aligned glandular cell outlets type on segment 1. Minute glandular cell outlets type 2 in subdorsal positions on segment 2, and in laterodorsal positions on segments 8 and 9 . Tergal extensions of segment 11 short and pointed; margin of sternal extensions straight, with ventrolateral seta-like tuft of extended fringe tips. Females with female papillae with tubular substructure in ventrolateral positions on segment 7 and ventromedial positions on segment 8; males with ventrolateral sensory spots on segment 10 .

\section{Material examined}

Lectotype (here designated)

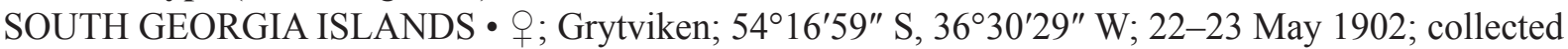
during the Swedish Antarctic Expedition in Grytviken; SMNH 3930. Specimen mounted for LM.

\section{Paralectotypes}

SOUTH GEORGE ISLANDS • 15 우, $18 \hat{\partial} \hat{\partial}, 3$ uncertain sex; same collection data as for lectotype;

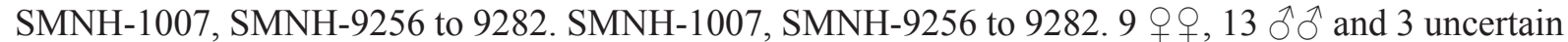
sex mounted for LM; 6 우, 5 숭 mounted for SEM;

\section{Remarks}

Higgins (1986) mentions that he accessed the type material of E. pilosus in SMNH, mounted and observed two paratypic specimens. However, such mounted specimens were found in neither the SMNH nor the USNM.

After examining the syntypes and providing the present redescription we choose, in the interest of assuring future taxonomic stability, to designate one of the female syntype as lectotype for Echinoderes pilosus with the catalogue number SMNH-3930, and consequently designate the remaining specimens as paralectotypes (SMNH-1007, 9256-9282).

\section{Description}

The species was described by Lang (1949), and more recently redescribed by Higgins (1986). However, since information from SEM not previously has been available for the species, and since the present examinations with LM and SEM resulted in substantial new information about the morphology of the species, we are here providing a full redescription.

Adults with head, neck and eleven trunk segments. The anterior part of the trunk is relatively stout, and maximum width is reached around segments 6 and 7 (Fig. 9A-B). From segment 8 the segments taper significantly, giving the species an appearance of a pointed hind end (Fig. 9A-B). The trunk cuticle appears thin in SEM specimens (Fig. 10A), and tends to collapse posterior to the stronger pachycycli. Secondary pectinate fringe present near anterior segment margin on segments 2 to 10 . For complete overview of measurements and dimensions, see Table 9. Distribution of cuticular structures, i.e., sensory spots, glandular cell outlets, spines and tubes, is summarized in Table 10.

The head consists of a retractable mouth cone and an introvert. Inner oral styles could not be examined. Nine outer oral styles are present; nine tufts with ca. six long, rigid and distally bifurcated tips in each, attach basally on the mouth cone, posterior to each outer oral style. The exact arrangement of scalids could not be examined.

The neck has 16 placids, measuring $19 \mu \mathrm{m}$ in length. The midventral placid is broadest, measuring $17 \mu \mathrm{m}$ in width at its base, whereas all other are narrower, measuring $10 \mu \mathrm{m}$ in width at their bases. 

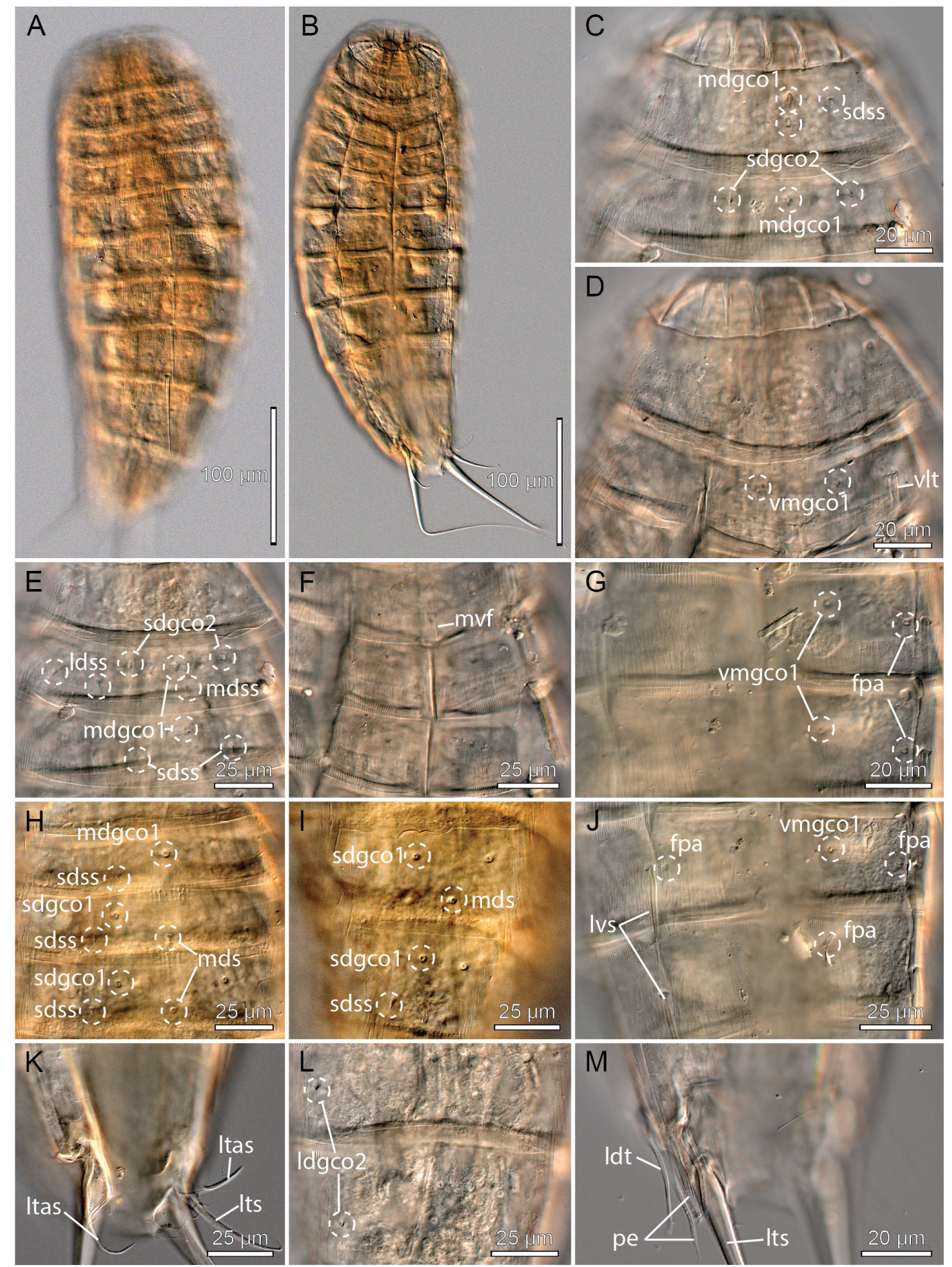

Fig. 9. Light micrographs showing overviews and details of Echinoderes pilosus Lang, 1949. A-B, G-L. Lectotype, + (SMNH-3930a). C-F, M. Paralectotype, đ̊ (SMNH-3930b). A. Dorsal overview. B. Ventral overview. C. Segments 1 to 2, dorsal view. D. Segments 1 to 2, ventral view. E. Segments 1 to 3, dorsal view. F. Segments 2 to 4, ventral view. G. Segments 6 to 7, ventral view, showing female sexual dimorphism. H. Segments 3 to 5, dorsal view. I. Segments 8 to 9, dorsal view. J. Segments 7 to 8 , ventral view, showing female sexual dimorphism. K. Segments 10 to 11, ventrolateral view, showing female sexual dimorphism. L. Segments 8 to 9 , dorsal view but deeper focal plane than (I). M. Segments 10 to 11 , ventral view, showing male sexual dimorphism. 

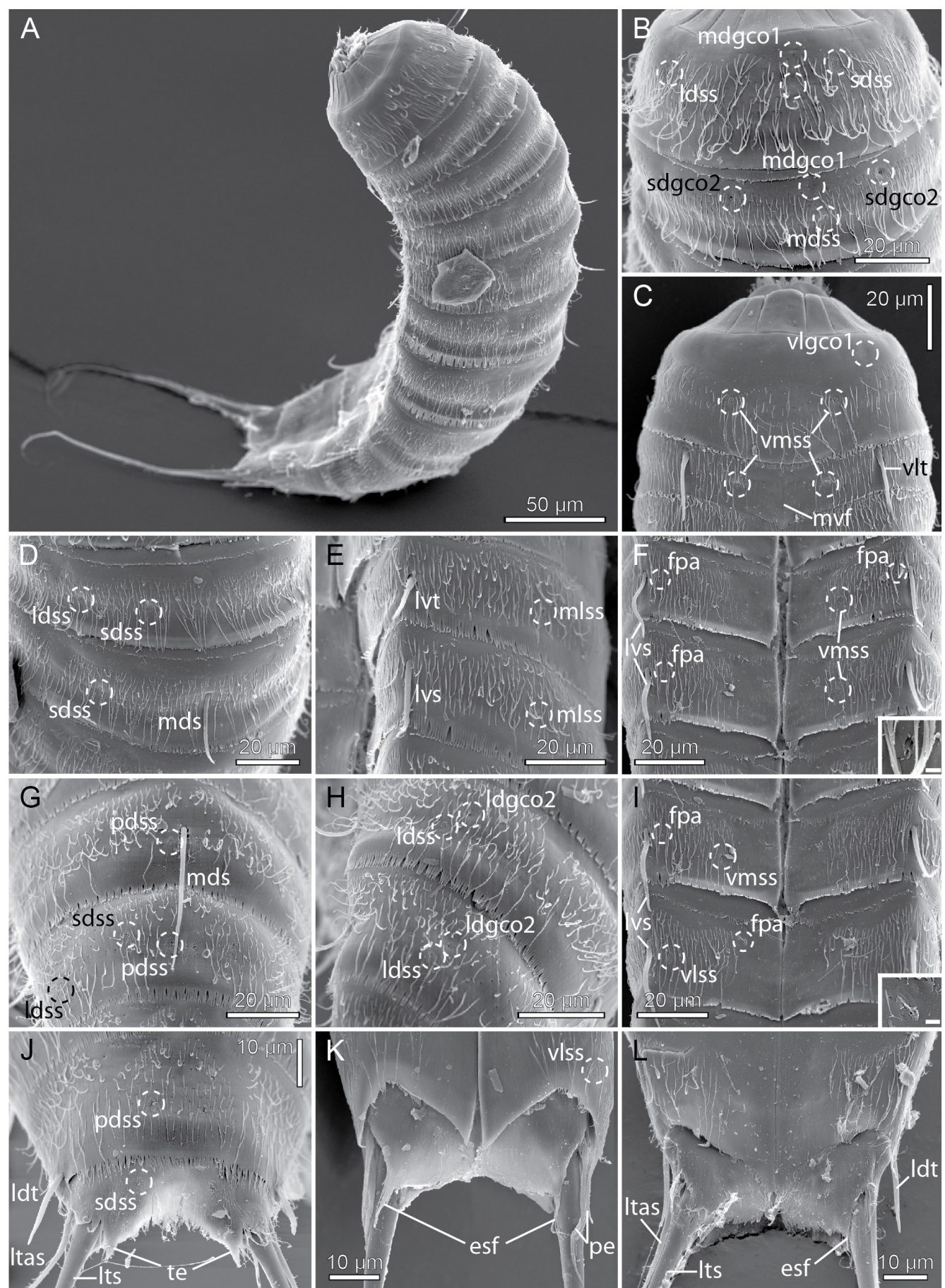

Fig. 10. Scanning electron micrographs showing overviews and details of Echinoderes pilosus Lang, 1949. A-J, L. + (SMNH-9262, SMNH-9281). K. ${ }^{\uparrow}$ (SMNH-9262). A. Lateral overview. B. Segments 1 to 2, dorsal view. C. Segments 1 to 2, ventral view. D. Segments 3 to 4, dorsal view. E. Segments 5 to 6 , lateral view. F. Segments 6 to 7, ventral view, showing female sexual dimorphism; inset shows ventrolateral female papilla on segment 6 , scale on inset $=1 \mu \mathrm{m}$. G. Segments 8 to 9 , dorsal view. H. Segments 8 to 9, laterodorsal view. I. Segments 7 to 8 , ventral view, showing female sexual dimorphism; inset shows ventromedial female papilla on segment 8 , scale on inset $=2 \mu \mathrm{m}$. J. Segments 10 to 11 dorsal view, showing female sexual dimorphism. K. Segments 10 to 11 ventral view, showing male sexual dimorphism. L. Segments 10 to 11 ventral view, showing female sexual dimorphism. 
Table 9. Measurements from light microscopy for lectotype and nine paralectotypes of Echinoderes pilosus Lang, 1949 from Grytviken, South Georgia Island (in $\mu \mathrm{m}$ ), including number of measured specimens $(n)$ and standard deviation (SD).

\begin{tabular}{|c|c|c|c|c|}
\hline Character & $n$ & Range & Mean & SD \\
\hline $\mathrm{TL}$ & 14 & $343-440$ & 389 & 28.83 \\
\hline MSW-8 & 14 & 79-90 & 86 & 3.09 \\
\hline MSW-8/TL & 11 & $19.0-25.1 \%$ & $22.5 \%$ & $1.86 \%$ \\
\hline SW-10 & 15 & $65-78$ & 71 & $4.24 \%$ \\
\hline SW-10/TL & 11 & $15.4-20.0 \%$ & $18.6 \%$ & $1.44 \%$ \\
\hline $\mathrm{S} 1$ & 14 & $36-54$ & 44 & 5,70 \\
\hline $\mathrm{S} 2$ & 14 & $27-41$ & 34 & 4,43 \\
\hline S3 & 15 & $26-33$ & 30 & 1,99 \\
\hline S4 & 15 & $27-37$ & 33 & 2,93 \\
\hline S5 & 15 & $31-38$ & 35 & 1,93 \\
\hline S6 & 17 & $33-43$ & 38 & 2,76 \\
\hline S7 & 18 & $35-49$ & 42 & 3,60 \\
\hline S8 & 17 & $40-52$ & 46 & 3,46 \\
\hline S9 & 16 & $42-55$ & 49 & 3,07 \\
\hline $\mathrm{S} 10$ & 15 & $51-61$ & 55 & 3,70 \\
\hline S11 & 15 & $30-40$ & 34 & 3,40 \\
\hline MD4 (ac) & 20 & $29-47$ & 35 & 3,66 \\
\hline MD5 (ac) & 19 & $33-48$ & 39 & 4,00 \\
\hline MD6 (ac) & 19 & $38-57$ & 44 & 4,22 \\
\hline MD7 (ac) & 22 & $42-61$ & 49 & 4,65 \\
\hline MD8 (ac) & 22 & $60-80$ & 70 & 5,65 \\
\hline LV2 (tu) & 21 & $24-44$ & 31 & 4,00 \\
\hline LV5 (tu) & 23 & $24-34$ & 30 & 2,97 \\
\hline LV6 (ac) & 24 & $26-37$ & 31 & 2,83 \\
\hline LV7 (ac) & 25 & $28-42$ & 37 & 3,08 \\
\hline LV8 (ac) & 23 & $36-43$ & 41 & 1,75 \\
\hline LV9 (ac) & 22 & $38-54$ & 44 & 3,33 \\
\hline ML10 (tu) & 23 & $28-38$ & 32 & 2,80 \\
\hline LTS & 20 & $163-205$ & 186 & 9,80 \\
\hline LTS/TL & 12 & $39.9-56.4 \%$ & $48.0 \%$ & $4.58 \%$ \\
\hline LTAS & 9 & $46-48$ & 52 & 3.91 \\
\hline
\end{tabular}


The trichoscalid plates are well-developed, subdorsal and laterodorsal ones narrow and elongated, and ventromedial ones broadly oval.

Segment 1 consists of a complete cuticular ring. Sensory spots are located on the anterior segment half in subdorsal, laterodorsal, and sublateral positions, and medially on segment, in ventromedial positions (Figs 9C, 10B-C); sensory spots on this all following segments are small, and rounded, with numerous micropapillae. Two longitudinally arranged glandular cell outlets type 1 are present in middorsal position (Figs 9C, 10B); anteriormost outlet appears narrower and more elongate than the posterior one; an additional pair of glandular cell outlets type 1 is present in ventrolateral positions (Fig. 10C). Dorsal and lateral sides, with scattered cuticular hairs emerging through rounded perforation sites; posterior half of ventral side with similar hair covering, but anterior part with large, W-shaped hairless area (Fig. 10B-C). The posterior segment margin is straight along the dorsal and lateral sides, and slightly convex ventrally, terminating into a pectinate fringe with short and very flexible fringe tips. Pachycyclus thin to medium thickness, and not interrupted.

Segment 2 consists of a complete cuticular ring, but with indication of an intracuticular, partial, midventral fissure (Figs 9F, 10C). Sensory spots are located in middorsal (but slightly laterally displaced), laterodorsal (twin pair) (Figs 9E, 10B) and ventromedial positions (Fig. 10C). Minute glandular cell outlets type 2 present in subdorsal positions (Figs 9C, 10B), and tubes present in ventrolateral positions (Figs 9D, 10C). Glandular cell outlets type 1 present in middorsal and ventromedial positions (Figs 9C$\mathrm{D}, 10 \mathrm{~B})$. The segment is densely covered with bracteate hairs, but interrupted by hairless areas posterior to ventrolateral tubes, and in paraventral areas. Pachycyclus of the anterior segment margin is of medium thickness and not interrupted. The posterior segment margin is straight along dorsal and lateral sides, and extend into V-shaped flap on the ventral side; pectinate fringe from middorsal to midlateral positions with short fringe tips, as on segment 1; fringe tips from midlateral to ventromedial positions longer and very flexible, and then very short between ventromedial positions.

Segment 3, and remaining segments, consisting of one tergal and two sternal plates. Pachycyclus of the anterior segment margin of medium thickness, and interrupted only at tergosternal junctions. Sensory spots present in subdorsal, laterodorsal (Figs 9E, 10D) and sublateral positions. Glandular cell outlets type 1 present in middorsal (Fig. 9E, H) and ventromedial positions. Bracteate cuticular hairs are densely covering the segment from middorsal to ventromedial positions (except in V-shaped areas in laterodorsal positions anterior on segment); paraventral areas that are devoid of any hair-like structures. Pectinate fringe of posterior margin as on preceding segment, but with ventromedial fringe tips being slightly longer.

Segment 4 with acicular spine in middorsal position, reaching attachment point of middorsal spine on following segment (Fig. 10D); this and all other spines on following five segments are slender and flexible. Sensory spots present in subdorsal (Figs 9H, 10D), midlateral and ventromedial positions; midlateral and ventromedial sensory spots considerably smaller than most other sensory spots in the species, but they occur consistently in all examined specimens. Glandular cell outlets type 1 present in subdorsal (Fig. 9H) and ventromedial positions. Pectinate fringe of posterior segment margin, pachycycli and cuticular hairs as on preceding segment.

Segment 5 with acicular spine in middorsal position, reaching attachment point of middorsal spine on following segment, and long, slender tubes in lateroventral positions (Fig. 10E). Sensory spots present in subdorsal, midlateral (Figs 9H, 10E) and ventromedial positions; ventromedial sensory spots considerably smaller than most other sensory spots in the species. Glandular cell outlets type 1, pachycycli, pectinate fringe of posterior margin and cuticular hairs as on preceding segment.

Segment 6 with acicular spine in middorsal position, reaching attachment point of middorsal spine on following segment, and in lateroventral positions (Fig. 10E-F), reaching beyond the posterior margin 
Table 10. Summary of nature and location of sensory spots, glandular cell outlets, tubes and spines arranged by series in Echinoderes pilosus Lang, 1949.

\begin{tabular}{|c|c|c|c|c|c|c|c|c|c|c|}
\hline $\begin{array}{l}\text { Position } \\
\text { Seggment }\end{array}$ & MD & PD & SD & LD & ML & SL & LA & LV & VL & VM \\
\hline 1 & gcol, gco1 & & ss & ss & & ss & & & gcol & ss \\
\hline 2 & gcol, ss & & gco2 & ss, ss & & & & & tu & gcol, ss \\
\hline 3 & gco1 & & ss & ss & & ss & & & & gcol \\
\hline 4 & $\mathrm{ac}$ & & gcol, ss & & ss* & & & & & $\mathrm{ss}^{*}$, gco1 \\
\hline 5 & $\mathrm{ac}$ & & gcol, ss & & ss & & & tu & & ss*, gcol \\
\hline 6 & ac & ss & gcol & & ss & & & $\mathrm{ac}$ & fpa (P) & ss, gcol \\
\hline 7 & $\mathrm{ac}$ & ss & gcol & & ss & & & $\mathrm{ac}$ & fpa (†) & ss, gco1 \\
\hline 8 & $\mathrm{ac}$ & ss & gcol & gco2, ss & & & & $\mathrm{ac}$ & ss & gco1, fpa (早) \\
\hline 9 & & ss & gcol, ss & gco2, ss & & & si & $\mathrm{ac}$ & ss & gcol \\
\hline 10 & gcol, gco1 & ss & & tu & & & & & ss $\left(\widehat{o}^{3}\right)$ & gcol \\
\hline 11 & gcol, gco1 & & ss & & $3 x p e\left({ }^{3}\right)$ & & ltas ( $($ ) & lts & & \\
\hline
\end{tabular}

of the segment. Females with female papillae in ventrolateral positions; openings of papillae with fine fringes around their margins (Fig. 10F inset); intracuticular substructures each form an indistinct tubular structure (Fig. 9G). Sensory spots present in paradorsal, midlateral and ventromedial (Fig. 10F) positions. Pectinate fringe of posterior segment margin with uniform long fringe tips on tergal plate and on most lateral halves of sternal plates; fringe tips shorter between ventromedial positions. Glandular cell outlets type 1 , pachycycli and cuticular hairs as on preceding segment.

Segment 7 with acicular spine in middorsal position, extending about halfway over the following segment, and in lateroventral positions, reaching beyond the posterior margin of the segment. Female papillae (Figs 9G, J, 10F, I), sensory spots, glandular cell outlets type 1, pachycycli, pectinate fringe of posterior margin and cuticular hairs as on preceding segment.

Segment 8 with acicular spine in middorsal position, extending more than halfway over the following segment (Fig. 10G), and in lateroventral positions (Fig. 9J), reaching beyond the posterior margin of the segment (Fig. 10I). Minute glandular cell outlets type 2 present in laterodorsal positions (Figs 9L, 10H). Sensory spots present in paradorsal, laterodorsal (posterior to glandular cell outlets) and ventrolateral positions (Fig. 10G-I). Females with female papillae in ventromedial positions (Figs 9J, 10I); openings of papillae with fine fringes around their margins (Fig. 10I inset); intracuticular substructures each form an indistinct tubular structure. Glandular cell outlets type 1 as on preceding segment, but subdorsal ones are situated slightly closer to each other (Fig. 9I). Pachycycli, pectinate fringe of posterior margin and cuticular hairs as on preceding segment.

Segment 9 with acicular spines in lateroventral positions, extending about halfway over the following segment. Minute glandular cell outlets type 2 present in laterodorsal positions (Figs 9L, 10H). Sensory spots present in paradorsal, subdorsal, laterodorsal (Fig. 10G-H), and ventrolateral positions. Female papillae absent. Glandular cell outlets type 1 as on preceding segment, but with subdorsal ones situated even closer to each other, very close to paradorsal positions. Small, rounded nephridial sieve plates present in lateral accessory positions. Pachycycli, pectinate fringe of posterior margin and cuticular hairs as on preceding segment. 
Segment 10 with long, slender laterodorsal tubes near posterior segment margin (Figs 9M, 10J, L). Sensory spots present in paradorsal positions (Fig. 10J); males with additional pair of sensory spots in ventrolateral positions (Fig. 10K). Glandular cell outlets type 1 present as two longitudinally arranged middorsal ones and in ventromedial positions. The posterior segment margin of the tergal plate is straight, whereas margins of sternal plates are concave and extend into a midventral point (Fig. 10K); fringe tips of pectinate fringe are as on preceding segment on tergal plate, but considerably shorter on sternal plates. Cuticular hairs as on preceding segments on tergal plates, but more sparse on sternal plates. Pachycycli as on preceding segment.

Segment 11 with lateral terminal spines (Fig. 9B, K, M). Males with three pairs of penile spines (Figs 9M, $10 \mathrm{~K}$ ); dorsal and ventral penile spines are stout but still flexible tubes, whereas the median ones are slightly thicker and more rigid; females with short, and relatively stout lateral terminal accessory spines (Figs 9K, 10J, L). Sensory spots present in subdorsal positions medially on segment. Two longitudinally arranged glandular cell outlets type 1 present in middorsal position, anterior on segment. The dorsal side of the segment is sparsely covered with thin, non-bracteate hair-like extensions; ventral side is almost hair-less. Tergal extensions are well-spaced, short and pointed; sternal extensions short, with ventrolateral seta-like tuft of extended fringe tips (Fig. 10K-L).

Echinoderes sensibilis Adrianov, Murakami \& Shirayama, 2002

Figs 11-15; Tables $11-12$

\section{Emended diagnosis}

Echinoderes with short middorsal spines on segments 4 to 8, and lateroventral spines on segments 6 to 9; middorsal spines on posterior segments barely or just reaching the posterior margin of their respective segments. Tubes present in lateroventral positions on segments 2 and 5, and in laterodorsal positions on 10. Minute glandular cell outlets type 2 in midlateral positions on segments 8 and 9 . Tergal extensions of segment 11 short, pointed and well-spaced; sternal extensions short, with ventrolateral seta-like tuft of extended fringe tips. Females with ventromedial female papillae resembling glandular cell outlets type 2 on segments 6 to 8 ; intracuticular substructure of female papillae crescentic on segment 6 , and tubular on segments 7 and 8 .

\section{Material examined}

Holotype

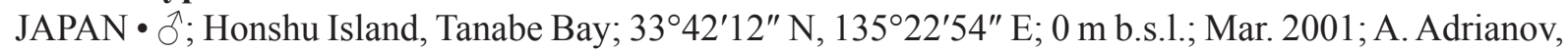
C. Murakami and Y. Shirayama leg.; calcareous red algae (Corallina pilulifera) in tidal pool; SMBL CM-A-JAP-E04. Specimen mounted for LM.

\section{Paratypes}

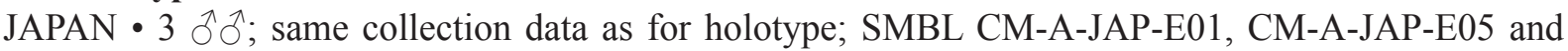
CM-A-JAP-E08.

Specimens mounted for LM. One specimen was incorrectly identified as female in the original description.

\section{Additional material}

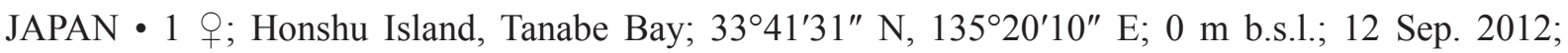
H. Yamasaki leg.; detritus and mixed sediment in tidal pool; GenBank: LC557098; ICHUM-6127.

DNA was extracted from this specimen, and cytochrome oxidase subunit 1 was sequenced. The cuticle of the specimen was subsequently recovered and mounted for LM (ICHUM-6127). 


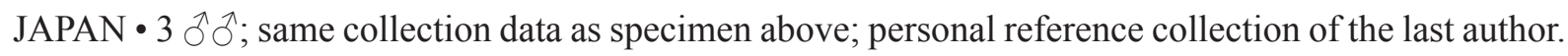
Specimens mounted for SEM.

Additional specimens from the same locality were collected by C.Y. Chang, mounted for SEM, and stored in the personal reference collection of the first author.

JAPAN • 1 q; Okinawa, Sesoko Station; 26³9'00" N, 12751'22" E; 0 m b.s.1.; 10 Nov. 2016; S. Fujimoto leg.; coarse sand in tidal pool; NHMD-115257. Specimen mounted for LM.

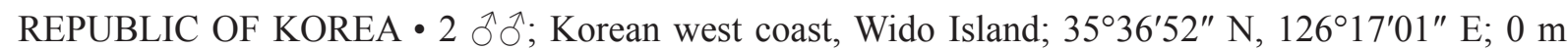
b.s.1.; 31 Feb. 2000; J. Lee and Y.H. Song leg.; intertidal macroalgae; NHMD-664200, NHMD-664201

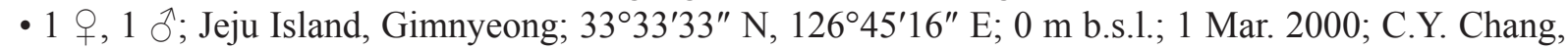
J. Lee and Y.H. Song leg.; intertidal macroalgae; NHMD-664202, NHMD-664203・ 1 j; Jeju Island, Udo Islet; 3331'03" N, $126^{\circ} 57^{\prime} 40^{\prime \prime}$ E; 0 m b.s.1.; 3 May 2000; C.Y. Chang and J. Lee leg.; intertidal macroalgae; NHMD-664204.

All Korean specimens mounted for LM.

HAWAII • 4 우, 6 ふう; Oahu, Kaneohe Bay, lagoon at Coconut Island, St. MVS-0224-HI-01 (= workshop St. KANM005); $21^{\circ} 26^{\prime} 09^{\prime \prime}$ N, 157 $47^{\prime} 18^{\prime \prime}$ W; 0,5 m b.s.1.; 22 May 2017; M. V. Sørensen leg.; subtidal black mud, rich in organic matter; GenBank: MT999943; NHMD-662049 to 662058.

Specimens were mounted for LM. Additional 5 우, 5 of collected at the same station were mounted for SEM and stored in the first author's personal reference collection. One specimen was picked up for molecular barcoding and a 625 bp long cytochrome oxidase subunit 1 sequence was deposited in GenBank under accession number MT999943; the cuticle could not be recovered afterwards, but the specimen used for DNA extraction is shown on Fig. 11.

HAWAII • 6 우, 4 ổ; Oahu, Kaneohe Bay, He'ia Fish Pond, St. MVS-0229-HI-06 (= St. KANM034); $21^{\circ} 26^{\prime} 05^{\prime \prime} \mathrm{N}, 157^{\circ} 48^{\prime} 19^{\prime \prime} \mathrm{W} ; 3$ m b.s.l.; 24 May 2017; workshop participants leg.; subtidal black mud, very rich in organic matter; NHMD-662059 to 662068.

Specimens were mounted for LM. Additional 7 우, 3 ô collected at the same station were mounted for SEM and stored in the first author's personal reference collection.

See Table 1 for an overview.

\section{Redescription}

Since the present redescription adds several new features to the species, including information on head structures, observations of live material, and significant diagnostic traits, and since the distributional range of the species is extended considerably, we are providing a full description for the species. As much information as possible is based on observations of the type material, but the specimens are partly deteriorated, hence structures such as sensory spots could no longer be observed. Additional information is primary based on examination of topotypes, supplemented with information from Okinawa and Hawaii populations that morphologically agreed completely with the topotypes.

Adults with head, neck and eleven trunk segments (Figs 11-13, 14A, 15A). Glandular cells appear brown-red in live specimens, giving the species a conspicuous longitudinal colour pattern along its trunk (Fig. 11). The colouring fades, and eventually disappears, when the animal is fixed. The trunk appears stout, with nearly equally broad sternal plates on segments 6 to 10 (Figs 11A, C, 14A). Segments 1 to 4 were often strongly contracted in fixed specimens. Lateral terminal spines slender, from $40 \%$ to $55 \%$ 
of trunk length. For complete overview of measurements and dimensions, see Table 11. Secondary pectinate fringe present near anterior segment margin on segments 2 to 10 , but it is usually covered by the preceding segment. Distribution of cuticular structures, i.e., sensory spots, glandular cell outlets, spines and tubes, is summarized in Table 12.

The head consists of a retractable mouth cone and an introvert (Figs 13, 15B-C). Three rings of inner oral styles present, with five styles in each ring (Fig. 13). The external mouth cone armature consists of nine outer oral styles; bases of outer oral styles each with a V-shaped row of short fringe tips and a central bristle of much longer fringe tips (Fig. 15B). The introvert sectors are defined by the ten primary spinoscalids in Ring 01 (Figs 13, 15C). Each primary spinoscalid consists of a basal sheath and a distal end piece with a blunt tip. The sheaths have a well-defined basal, transverse fringe, and a less distinct fringe more distally on their exterior surfaces; fringe tips of the distal fringe attach along a longitudinal line and alternatingly projects to the left and to the right (see inset Fig. 4B for a similar morphology in a different species). End pieces are smooth and flexible. Rings 02 and 04 have 10 spinoscalids and Rings 03 and 05 have 20. All spinoscalids in these rings are well-developed, and consist of a basal sheath and a pointed end piece (Fig. 15C). The basal sheaths terminate into fine, fringed margins in spinoscalids of Rings 02 to 05 , and those of Rings 03 to 05 have in addition a basal median spike. A ring of short fringes extend around the introvert in between spinoscalid Rings 04 and 05 . Ring 06 has only six spinoscalids, located in sectors 1, 3, 5, 6, 7, and 9 (Fig. 13); Ring 06 spinoscalids resemble those in preceding sectors, but without a distinct differentiation into sheath and end piece. Ring 07 also has 6 spinoscalids, located as pairs in sectors 3 and 9, and unpaired but laterally displaced in sectors 5 and 7 (trichoscalids are taking up the space in the opposite side of each sector); Ring 07 spinoscalids resemble those in preceding sector.

Described sector-wise (Fig. 13), sectors 1 and 6 are similar, having spinoscalids arranged as two double diamonds. Sectors 2, 4, 8 and 10 all have spinoscalids arranged as a quincunx, located in between a medial anterior spinoscalid (Ring 02) and a trichoscalid plate. Sectors 3 and 9 have spinoscalids forming double diamonds anterior to a pair of spinoscalids. Sectors 5 and 7 also have spinoscalids forming double diamonds, but anterior to an unpaired, lateral spinoscalid (Fig. 13).

Regular trichoscalids with trichoscalid plates are present in sectors $2,4,5,7,8$, and 10 . In addition, a single trichoscalid without trichoscalid plate is present in sector 1 (Figs 13, 14H, 15C). The trichoscalid has the typical furry appearance (Figs 14H, 15C), but basally it also has a series of more well-organized pointed denticles.

The neck has 16 placids, measuring $18 \mu \mathrm{m}$ in length. The midventral placid is broadest, measuring $15 \mu \mathrm{m}$ in width at its base, whereas all other are narrower, measuring $11 \mu \mathrm{m}$ in width at their bases. The trichoscalid plates are well-developed; subdorsal and laterodorsal ones are narrow and elongated, and ventromedial ones broadly oval.

Segment 1 consists of a complete cuticular ring. Sensory spots are located near the anterior margin in subdorsal and laterodorsal positions, and slightly more posterior in sublateral and ventromedial positions (Figs 12A-B, 14B, 15D-E); sensory spots are large, and rounded to oval, with numerous micropapillae, two pores, and often a cilium emerging from one of the pores. Glandular cell outlets type 1 present in middorsal and lateroventral positions (Figs 12A-B, 14B-C, 15D-E); all glandular cells with type 1 outlets on this and following segments with conspicuous brown-red colouring that gets lost during fixation (Fig. 11A-B). Dorsal and lateral sides, and posterior half of ventral side, with scattered cuticular hairs emerging through rounded perforation sites. The posterior segment margin is straight around the segment, terminating into a pectinate fringe with short, uniform fringe tips. 
Segment 2 consists of a complete cuticular ring. Pachycyclus of the anterior segment margin is of medium thickness and not interrupted (Figs 11B, 14A-C). Sensory spots are located in middorsal (but slightly laterally displaced), laterodorsal (twin pair) and ventromedial positions (Figs 12A-B, 15D-E); sensory spots on this and all following segments as on segment 1, but slightly smaller. Glandular cell outlets type 1 present in middorsal and ventromedial positions, and quite well-developed tubes present in lateroventral positions (Figs 12A-B, 14B-C, 15D-E). The segment is densely covered with bracteate hairs; hair cover slightly thinner between ventromedial sensory spots. The posterior segment margin is nearly straight; pectinate fringe from middorsal to midlateral positions with short fringe tips, as on segment 1; fringe tips from midlateral to ventromedial positions conspicuously longer, and then again very short between ventromedial positions.

Segment 3, and remaining segments, consisting of one tergal and two sternal plates. Pachycyclus of the anterior segment margin of medium thickness, and interrupted only at tergosternal junctions (Figs 11B-C, 14C). Sensory spots present in subdorsal, laterodorsal and sublateral positions (Fig. 12AB). Glandular cell outlets type 1 present in middorsal and ventromedial positions (Figs 12A-B, 14B-C). Bracteate cuticular hairs are densely covering the segment from middorsal to ventromedial positions; paraventral areas densely covered by non-bracteate, hair-like extensions. Pectinate fringe of posterior margin hairs as on preceding segment.

Segment 4 with short acicular spine in middorsal position, not reaching the posterior margin of the segment (Figs 12A, 14B). Sensory spots present in subdorsal, midlateral and ventromedial positions (Fig. 12A-B); midlateral and ventromedial sensory spots considerably smaller than all other sensory
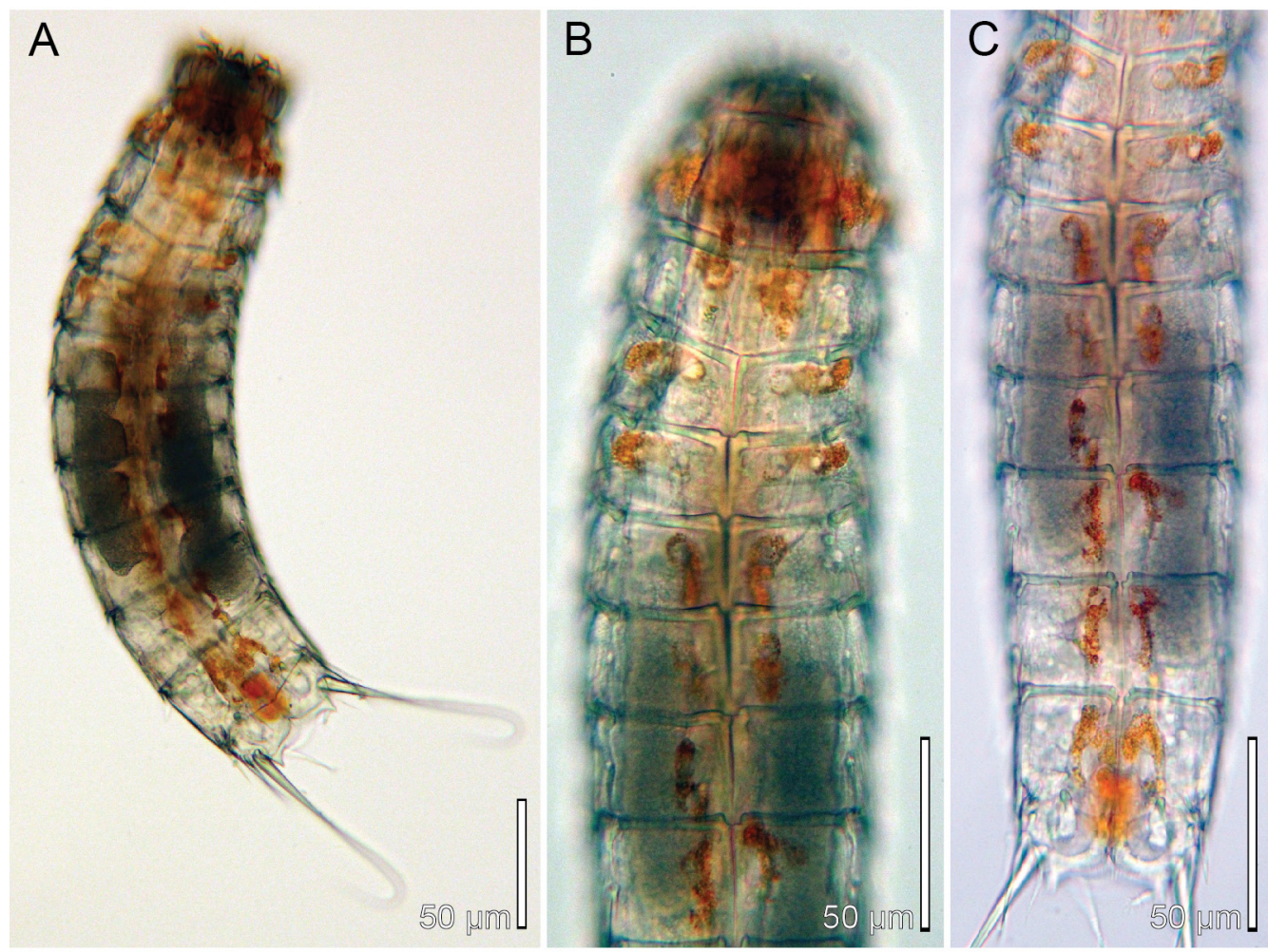

Fig. 11. Light micrographs showing overviews of live female of Echinoderes sensibilis Adrianov et al., 2002 from Coconut Island, Oahu, Hawaii (USNM-1616695). Note the brown-red glandular cells. DNA was subsequently extracted from the specimen and it is voucher for CO1 barcode sequence, GenBank Acc. number: MT999943. 

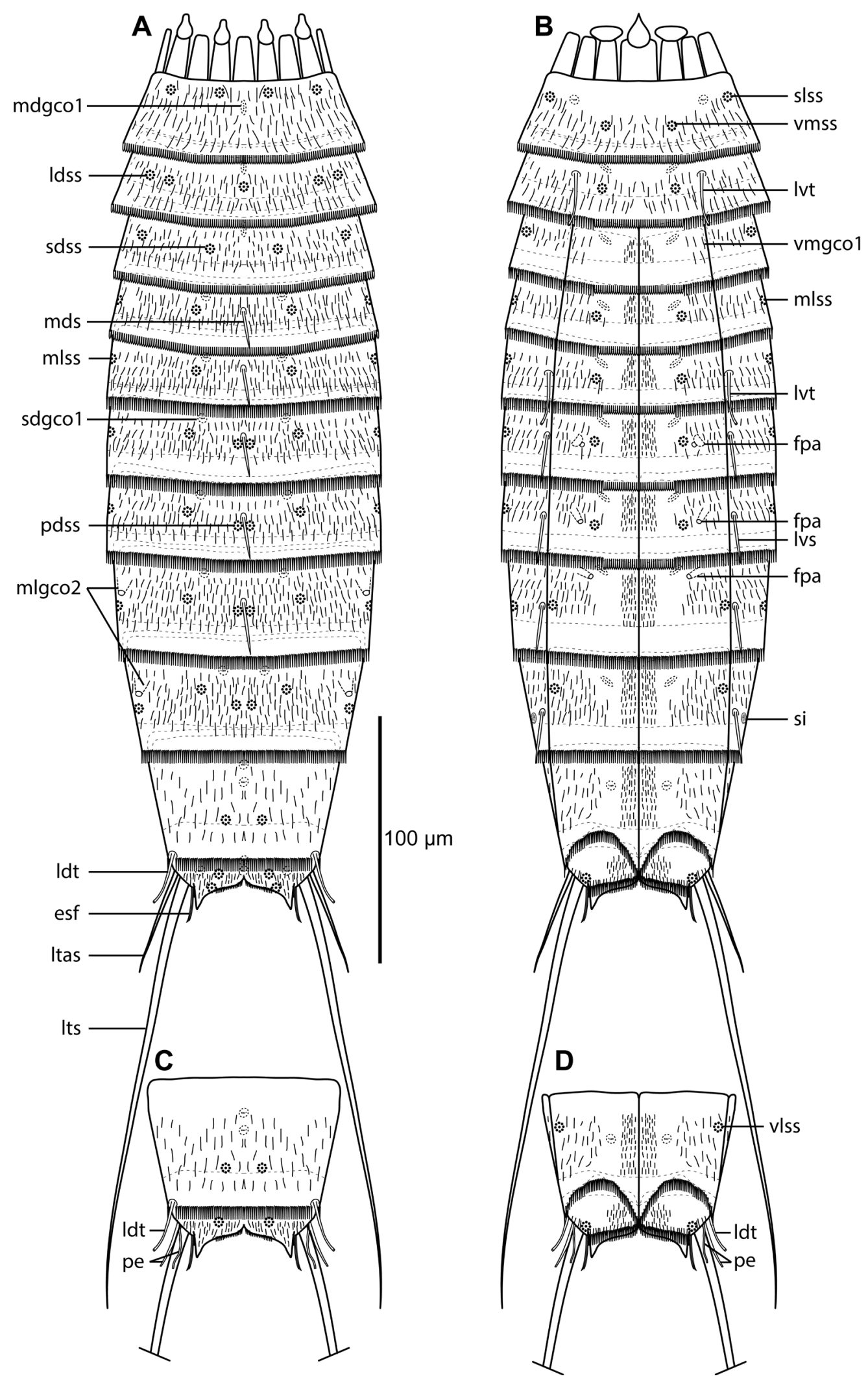

Fig. 12. Line art illustrations of Echinoderes sensibilis Adrianov et al., 2002. A. Female, dorsal view. B. Female, ventral view. C. Segments 10 to 11 in male, dorsal view. D. Segments 10 to 11 in male, ventral view. 


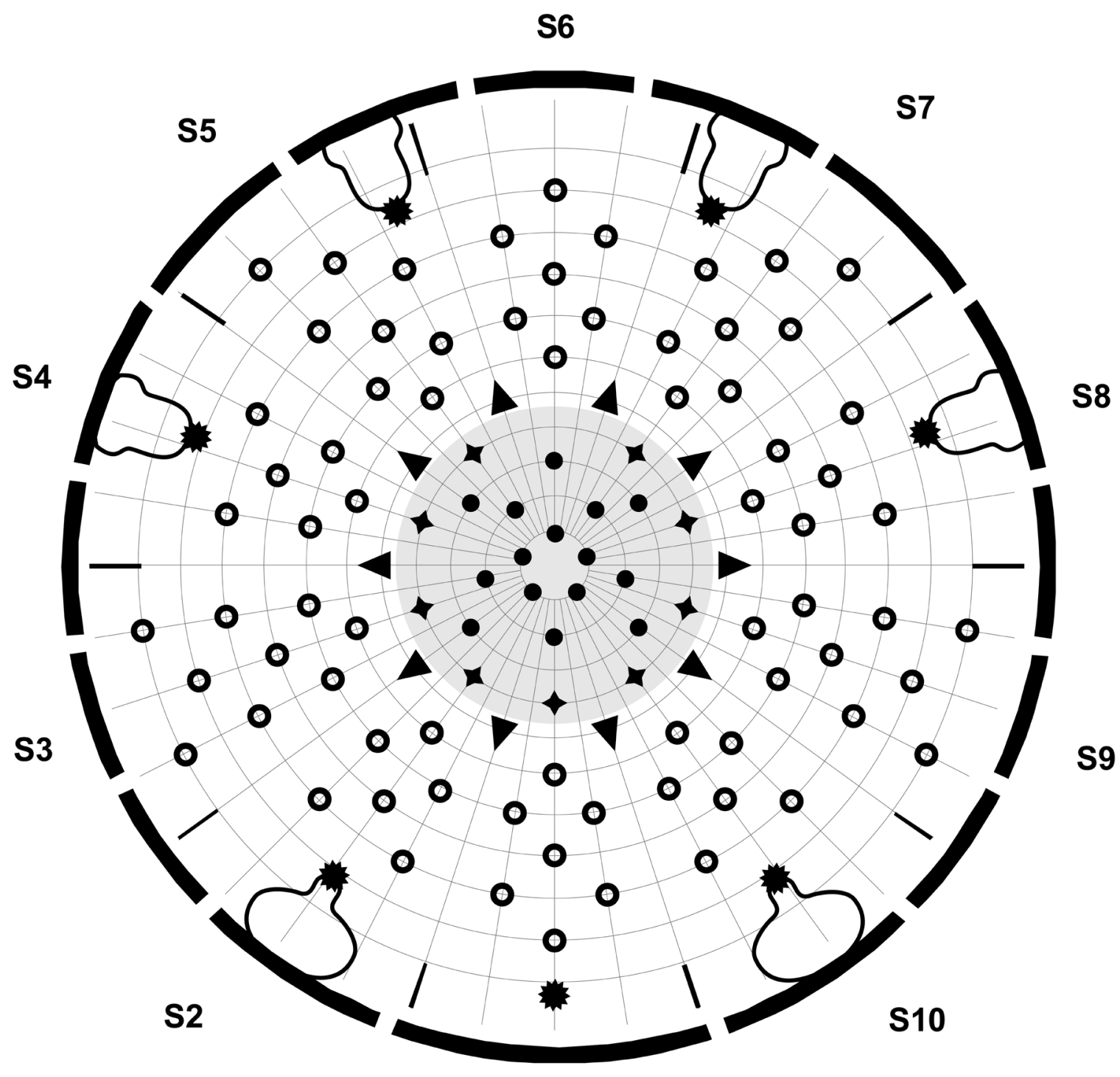

s1

Scalid and style arrangement

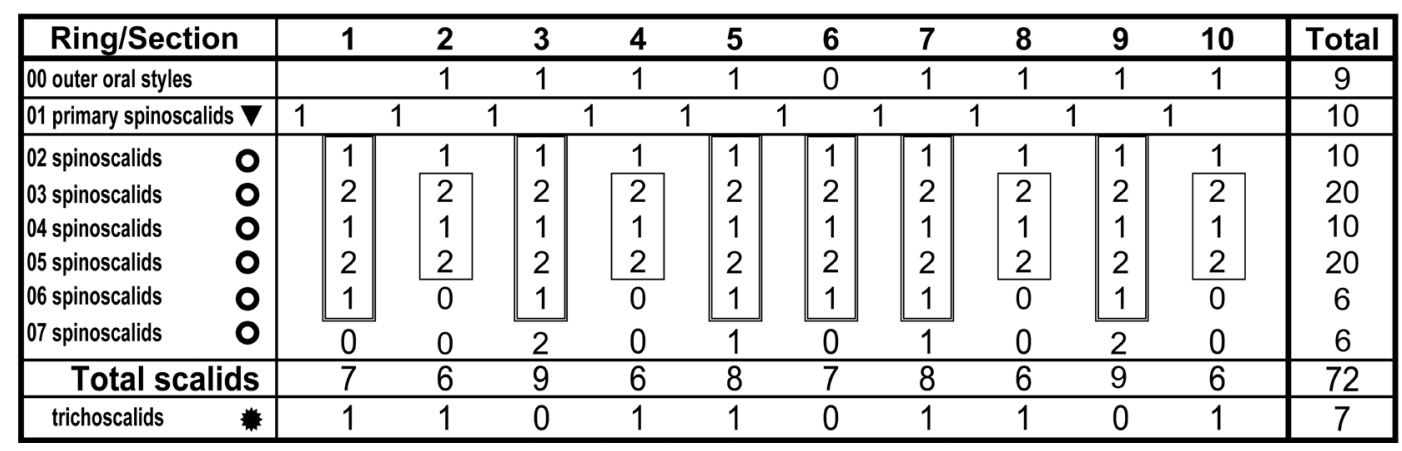

Fig. 13. Diagram of mouth cone (grey area), introvert and placids in Echinoderes sensibilis Adrianov et al., 2002, showing distribution of inner oral styles (full circles), outer oral styles (diamonds), primary scalids (triangles), spinoscalids (thick open circles) and trichoscalids (stars), with positions of trichoscalid plates and placids indicated. Table shows the scalid arrangement by sector; single-lined boxes mark quincunxes, double-lined boxes mark 'double diamonds'. 
Table 11. Measurements from light microscopy for four Japanese type specimens and selected specimens from the Hawaiian population of Echinoderes sensibilis Adrianov et al., 2002 (in $\mu \mathrm{m}$ ), including number of measured specimens $(n)$ and standard deviation (SD).

\begin{tabular}{|c|c|c|c|c|c|c|c|c|c|c|c|c|}
\hline \multirow{2}{*}{ Character } & \multicolumn{4}{|c|}{ Tanabe Bay, Japan (type material) } & \multicolumn{4}{|c|}{ Hawaii } & \multicolumn{4}{|c|}{ All } \\
\hline & $n$ & Range & Mean & SD & $n$ & Range & Mean & SD & $n$ & Range & Mean & SD \\
\hline $\mathrm{TL}$ & 4 & $342-383$ & 354 & 19.51 & 14 & $301-385$ & 335 & 26.81 & 18 & $301-385$ & 339 & 26.10 \\
\hline MSW-8 & 4 & $72-76$ & 74 & 2.06 & 14 & $69-76$ & 73 & 1.72 & 18 & $69-76$ & 73 & 1.84 \\
\hline MSW-8/TL & 4 & $19.8-22.2 \%$ & $21.0 \%$ & $0.98 \%$ & 14 & $19.2-24.2 \%$ & $21.8 \%$ & $1.53 \%$ & 18 & $19.2-24.2 \%$ & $21.6 \%$ & $1.44 \%$ \\
\hline SW-10 & 4 & $71-75$ & 73 & 1.83 & 14 & $68-73$ & 70 & 1.77 & 18 & $68-75$ & 71 & 2.14 \\
\hline SW-10/TL & 4 & $19.6-21.6 \%$ & $20.7 \%$ & $0.86 \%$ & 14 & $19.0-22.9 \%$ & $21.0 \%$ & $1.51 \%$ & 18 & $19.0-22.9 \%$ & $20.9 \%$ & $1.38 \%$ \\
\hline S1 & 4 & $34-37$ & 36 & 1.29 & 14 & $34-38$ & 35 & 1.22 & 18 & $34-38$ & 35 & 1.20 \\
\hline S2 & 4 & $36-38$ & 37 & 0.82 & 14 & $34-38$ & 36 & 1.16 & 18 & $34-38$ & 36 & 1.23 \\
\hline S3 & 4 & $35-40$ & 38 & 2.08 & 14 & $35-38$ & 37 & 1.07 & 18 & $35-40$ & 37 & 1.32 \\
\hline S4 & 4 & $37-41$ & 39 & 1.73 & 14 & $37-42$ & 40 & 1.68 & 18 & $37-42$ & 39 & 1.72 \\
\hline S5 & 4 & $40-49$ & 43 & 4.36 & 14 & $40-45$ & 43 & 1.55 & 18 & $40-49$ & 43 & 2.28 \\
\hline S6 & 4 & $44-50$ & 46 & 3.00 & 14 & $43-49$ & 46 & 1.92 & 18 & $43-50$ & 46 & 2.10 \\
\hline S7 & 4 & $46-52$ & 49 & 3.00 & 14 & $45-51$ & 49 & 1.90 & 18 & $45-52$ & 49 & 2.09 \\
\hline S8 & 4 & $50-52$ & 51 & 1.15 & 14 & $50-55$ & 53 & 1.40 & 18 & $50-55$ & 52 & 1.48 \\
\hline S9 & 4 & $53-54$ & 54 & 0.50 & 14 & $50-55$ & 53 & 1.33 & 18 & $50-55$ & 53 & 1.23 \\
\hline S10 & 4 & $53-55$ & 54 & 0.82 & 14 & $44-56$ & 50 & 3.17 & 18 & $44-56$ & 51 & 3.34 \\
\hline S11 & 4 & $40-42$ & 41 & 0.82 & 14 & $34-42$ & 38 & 1.86 & 18 & $34-42$ & 39 & 2.01 \\
\hline MD4 (ac) & 4 & $9-13$ & 11 & 1.71 & 11 & $10-15$ & 12 & 1.79 & 15 & $9-15$ & 12 & 1.74 \\
\hline MD5 (ac) & 3 & $11-14$ & 13 & 1.53 & 13 & $12-16$ & 14 & 1.27 & 16 & $12-16$ & 13 & 1.31 \\
\hline MD6 (ac) & 3 & $16-17$ & 16 & 0.58 & 13 & $13-19$ & 15 & 1.81 & 16 & $13-19$ & 16 & 1.67 \\
\hline MD7 (ac) & 4 & 19-20 & 20 & 0.58 & 14 & $13-22$ & 17 & 2.21 & 18 & $13-22$ & 17 & 2.25 \\
\hline MD8 (ac) & 3 & 21 & 21 & 0.00 & 13 & $17-26$ & 20 & 2.31 & 16 & $17-26$ & 20 & 2.13 \\
\hline & & & & & & & & & 13 & & & \\
\hline LV2 (tu) & 3 & $18-21$ & 20 & 1.73 & 10 & $20-24$ & 22 & 1.81 & & $18-24$ & 22 & 1.97 \\
\hline LV5 (tu) & 3 & $18-20$ & 19 & 1.00 & 10 & $17-25$ & 22 & 2.49 & 13 & $17-25$ & 21 & 2.56 \\
\hline LV6 (ac) & 3 & $14-19$ & 16 & 2.89 & 14 & $14-21$ & 17 & 2.00 & 17 & $14-21$ & 17 & 2.14 \\
\hline LV7 (ac) & 4 & $14-18$ & 15 & 1.89 & 14 & $15-22$ & 19 & 2.02 & 18 & $15-22$ & 18 & 2.49 \\
\hline LV8 (ac) & 4 & $16-20$ & 18 & 1.71 & 14 & $15-24$ & 20 & 2.27 & 18 & $15-24$ & 20 & 2.39 \\
\hline LV9 (ac) & 4 & $18-21$ & 19 & 1.41 & 14 & $17-25$ & 22 & 2.24 & 18 & $17-25$ & 21 & 2.33 \\
\hline LD10(tu) & 4 & $26-28$ & 27 & 0.96 & 12 & $23-30$ & 27 & 2.52 & 16 & $23-30$ & 27 & 2.21 \\
\hline LTS & 4 & $150-156$ & 154 & 2.65 & 14 & $132-168$ & 154 & 11.78 & 18 & $132-168$ & 154 & 10.37 \\
\hline LTS/TL & 4 & $39.2-45.2 \%$ & $43,5 \%$ & $2.88 \%$ & 14 & $39.5-55.6 \%$ & $46.2 \%$ & $4.35 \%$ & 18 & $39.2-55.6 \%$ & $45.6 \%$ & $4.15 \%$ \\
\hline LTAS & 0 & - & - & - & 8 & $40-45$ & 43 & 1.83 & 8 & $40-45$ & 43 & 1.83 \\
\hline
\end{tabular}


Table 12. Summary of nature and location of sensory spots, glandular cell outlets, tubes and spines arranged by series in Echinoderes sensibilis Adrianov et al., 2002.

\begin{tabular}{|c|c|c|c|c|c|c|c|c|c|c|}
\hline $\begin{array}{l}\text { Position } \\
\text { Segment }\end{array}$ & MD & PD & SD & LD & ML & SL & LA & LV & VL & VM \\
\hline 1 & gco1 & & ss & ss & & ss & & gco1 & & ss \\
\hline 2 & gcol, ss & & & ss, ss & & & & tu & & gcol, ss \\
\hline 3 & gcol & & ss & ss & & ss & & & & gcol \\
\hline 4 & ac & & gco1,s s & & ss* & & & & & ss*, gco1 \\
\hline 5 & $\mathrm{ac}$ & & gcol, ss & & ss & & & tu & & ss, gcol \\
\hline 6 & ac & ss & gcol, ss & & ss & & & $\mathrm{ac}$ & & fpa ( $(+)$, ss, gcol \\
\hline 7 & ac & ss & gcol, ss & & ss & & & $\mathrm{ac}$ & & fpa (†), ss, gcol \\
\hline 8 & ac & ss & gcol, ss & & $\mathrm{gco} 2, \mathrm{ss}$ & & & $\mathrm{ac}$ & ss & gco1, fpa (†) \\
\hline 9 & & ss & gco1, ss & & $\mathrm{gco} 2, \mathrm{ss}$ & & si & $\mathrm{ac}$ & ss & gcol \\
\hline 10 & gcol, gcol & & ss & tu & & & & & $\operatorname{ss}\left(\partial^{\lambda}\right)$ & gcol \\
\hline 11 & gcol, gcol & & gco1, ss, ss & & 3xpe (ठ) & & ltas $(P)$ & 1ts & ss & \\
\hline
\end{tabular}

spots in the species, but they occur consistently in all examined specimens. Glandular cell outlets type 1 present in subdorsal and ventromedial positions (Figs 12A-B, 14B-C). Pectinate fringe of posterior segment margin with long fringe tips from middorsal to ventromedial positions, and with very short tips between ventromedial positions. Pachycycli and cuticular hairs as on preceding segment.

Segment 5 with short acicular spine in middorsal position, not reaching the posterior margin of the segment (Figs 12A, 14D), and well-developed tubes in lateroventral positions (Figs 12B, 14E). Sensory spots present in subdorsal, midlateral and ventromedial positions (Fig. 12A-B). Glandular cell outlets type 1, pachycycli, pectinate fringe of posterior margin and cuticular hairs as on preceding segment.

Segment 6 with short acicular spines in middorsal and lateroventral positions (Figs 12A-B, 14DE, $14 \mathrm{G}-\mathrm{H}$ ), not reaching the posterior margin of the segment. Sensory spots present in paradorsal, subdorsal, midlateral and ventromedial positions (Figs 12A-B, 15G). Females with female papillae in ventromedial positions, close to and lateral to sensory spots (Figs 12B, 14E, 15H); openings of papillae resemble small glandular cell outlets type 2 (Fig. $15 \mathrm{H}$ ), and intracuticular substructures each form a semicircle with a small protuberance in the curved part of the structure (Fig. 14E). Glandular cell outlets type 1, pachycycli, pectinate fringe of posterior margin and cuticular hairs as on preceding segment.

Segment 7 with short acicular spines in middorsal and lateroventral positions, barely reaching the posterior margin of the segment (Figs 12A-B, 14D-E, 15G-I). Females with female papillae as on segment 6, but with openings slightly more anterior and lateral to sensory spots (Figs 12B, 14E, 15H-I); the substructure of these papillae differs from those on preceding segment, and forms instead a small intracuticular tube (Fig. 14E). Sensory spots, glandular cell outlets type 1, pachycycli, pectinate fringe of posterior margin and cuticular hairs as on preceding segment.

Segment 8 with short acicular spines in middorsal and lateroventral positions, barely or just reaching the posterior margin of the segment (Figs 12A-B, 14D-G, 15G, I). Minute glandular cell outlets type 2 present in midlateral positions, but very close to the laterodorsal areas (Figs 12A, 14G, 15F). Sensory spots present in paradorsal, subdorsal, midlateral (posterior to glandular cell outlets), ventrolateral positions (Figs 12A-B, 15F, I). Females with female papillae similar to those on segment 7, but with 


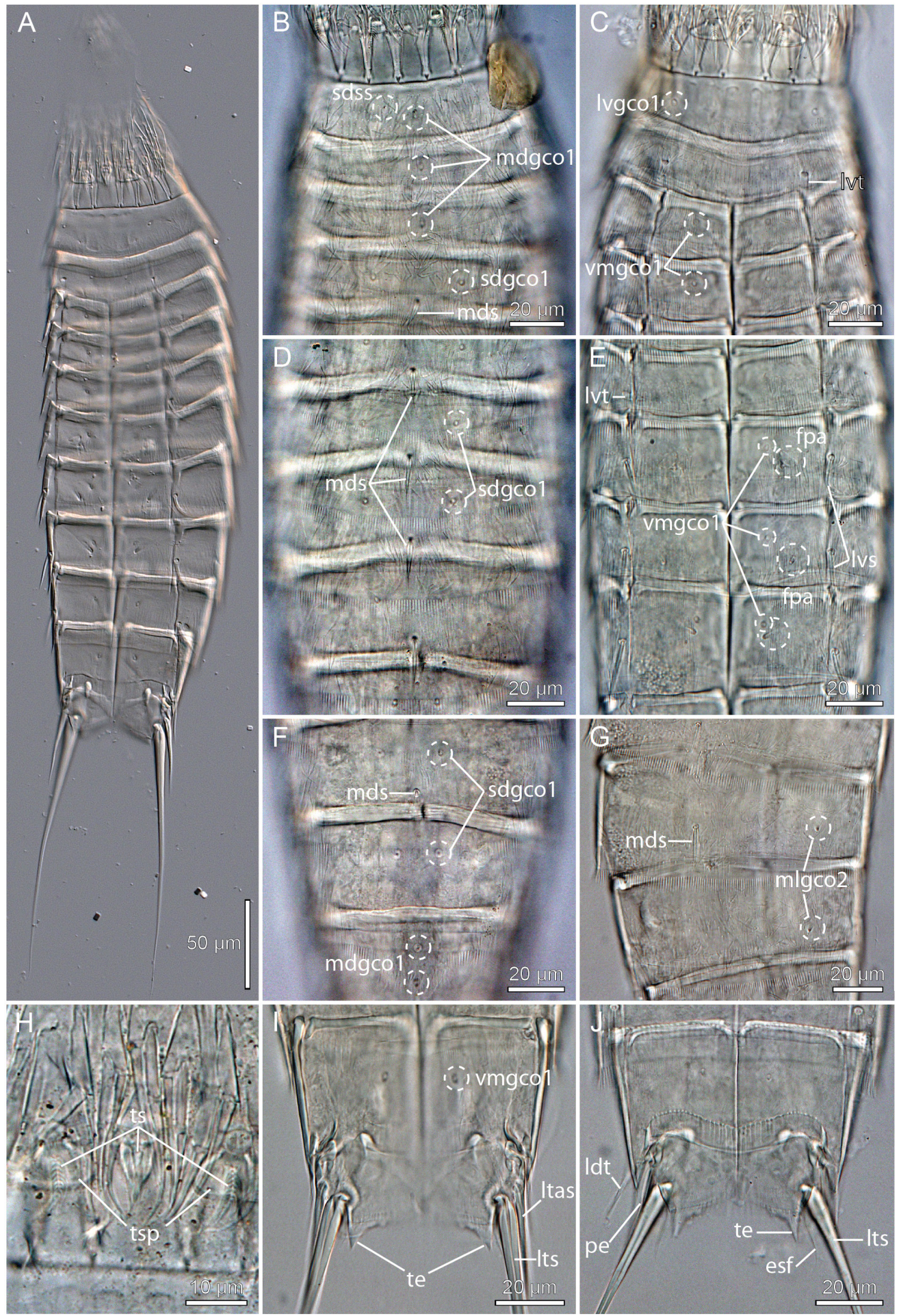

Fig. 14. Light micrographs showing overviews and details of Echinoderes sensibilis Adrianov et al., 2002. A-I. ․ . A. ICHUM-6127. B-F, I. NHMD-662049. G. NHMD-662066. H. NHMD-662060. A. Ventral overview. B. Segments 1 to 4, dorsal view. C. Segments 1 to 4, ventral view. D. Segments 5 to 8 , dorsal view. E. Segments 5 to 8 , ventral view, showing female sexual dimorphism. F. Segments 8 to 10 , dorsal view. G. Segments 8 to 9 , dorsal view. H. Detail showing ventral trichoscalids and trichoscalid plates. I. Segments 10 to 11, ventral view, showing female sexual dimorphism. J. § (NHMD-662056). Segments 10 to 11, ventral view, showing male sexual dimorphism. 

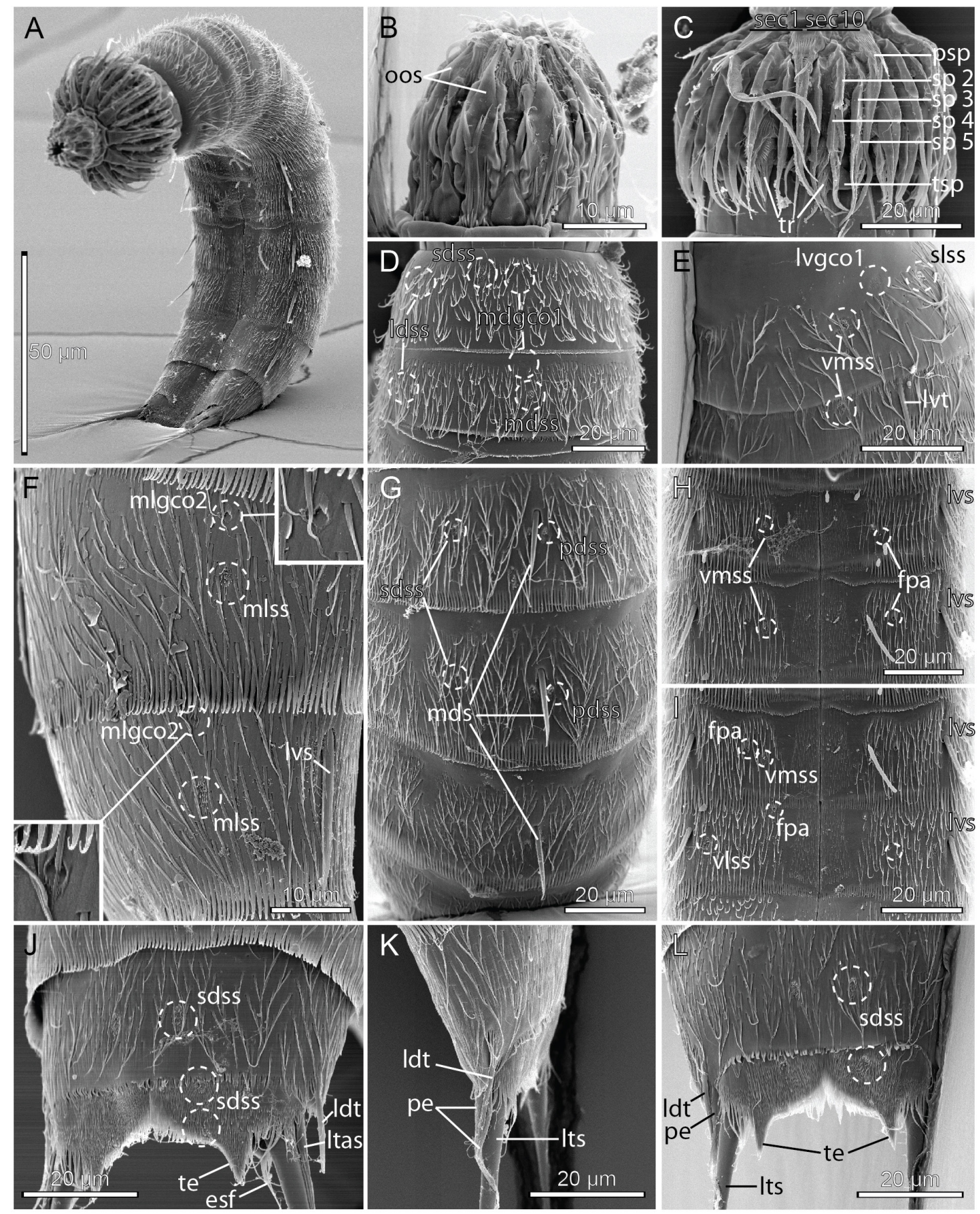

Fig. 15. Scanning electron micrographs showing overviews and details of Echinoderes sensibilis Adrianov et al., 2002. A, D, F-J. + (MVS, personal reference collection). B-C, E, K-L. $\lesssim$ (MVS, personal reference collection). A. Ventrolateral overview. B. Mouth cone, ventral view. C. Introvert sectors 1 and 10 (ventral). D. Segments 1 to 2, dorsal view. E. Segments 1 to 2, ventrolateral view. F. Segments 8 to 9, lateral view; insets show glandular cell outlets type 2. G. Segments 6 to 8 , dorsal view. H. Segments 6 to 7, ventral view, showing female sexual dimorphism. I. Segments 7 to 8 , ventral view, showing female sexual dimorphism. J. Segments 10 to 11, dorsal view, showing female sexual dimorphism. K. Segments 10 to 11, lateral view, showing male sexual dimorphism. L. Segments 10 to 11 , dorsal view, showing male sexual dimorphism. 
openings slightly more anterior and closer to midventral line (Figs 12B, 14E, 15I). Glandular cell outlets type 1, pachycycli, pectinate fringe of posterior margin and cuticular hairs as on preceding segment.

Segment 9 with acicular spines in lateroventral positions, just reaching the posterior margin of the segment (Figs 12B, 15F). Sensory spots, glandular cell outlets type 1 and 2 as on preceding segment, but female papillae not present (Figs 12A-B, 14F-G, 15F). Small, rounded nephridial sieve plates present in lateral accessory positions. Pectinate fringe of posterior segment margin with uniformly long fringe tips around the segment. Pachycycli and cuticular hairs as on preceding segment.

Segment 10 with well-developed laterodorsal tubes near posterior segment margin (Figs 12, 14J, 15J-L). Sensory spots present in subdorsal (but close to paradorsal) positions (Figs 12A, C, 15J, L); males furthermore with sensory spots in ventrolateral positions (Fig. 12D). Glandular cell outlets type 1 present as two longitudinally arranged middorsal ones and in ventromedial positions (Figs 12, 14I). The posterior segment margin of the tergal plate is straight, whereas margins of sternal plates are concave and extend midventrally into a point that almost reaches the posterior margin of the terminal segment; fringe tips of pectinate fringe are considerably shorter than those on preceding segments. Pachycycli and cuticular hairs as on preceding segment.

Segment 11 with lateral terminal spines (Figs 11A, 12A-B, 14A). Males with three pairs of penile spines (Figs 12C-D, 14J, 15K-L); dorsal and ventral penile spines are thin, flexible tubes, whereas the median ones are slightly thicker, conical, and more rigid; females with short, thin lateral terminal accessory spines (Figs 12A-B, 14I, 15J). Two pairs of sensory spots present in subdorsal positions and one pair in ventrolateral positions; one pair of subdorsal sensory spots medially on segment, other pair at posterior margin (Fig. 15J). Glandular cell outlets type 1 present as two longitudinally arranged middorsal ones and in subdorsal positions, anterior on segment. The dorsal and most of the ventral side of the segment are densely covered with non-bracteate hair-like extensions. Tergal extensions are wellspaced, short and pointed (Figs 12, 14I-J, 15J, L); sternal extensions short, with ventrolateral seta-like tuft of extended fringe tips (Figs 14J, 15J).

\section{Notes on habitat and ecology}

The specimens collected in Kaneohe Bay, Hawaii, showed a very clear preference for muddy localities, rich in organic matter. They seemed to thrive very well in it, and appeared in high numbers. Especially at the locality in He'ia Fish Pond (St. MVS-0229-HI-06) - an 800 year old fish pond established by isolating a part of the coastal water with a $2 \mathrm{~km}$ long lava rock wall - specimens of $E$. sensibilis occurred in ball-like aggregations composed of detritus, and up to 40 specimens. At low magnification, these balls would just resemble detritus pellets, but by gently opening the ball with a needle, it would appear that the balls mainly consisted of mass aggregated kinorhynchs.

\section{Echinoderes sublicarum Higgins, 1977}

Fig. 8C, F, I

\section{Emended diagnosis}

Echinoderes with middorsal spines on segments 4 to 8, and lateroventral spines on segments 6 to 9; middorsal spines on segments 5 to 8 extend well beyond the posterior margin of their respective segments. Tubes present in lateroventral positions on segments 2 and 5, and in laterodorsal positions on 10; tubes on segment 10 are long and slender. Minute glandular cell outlets type 2 in laterodorsal positions on segment 8 . Tergal extensions of segment 11 pointed, with additional tooth on inferior margin. Females with ventromedial female papillae formed by crescentic substructure and a tube on segment 8 ; similar ventrolateral female papillae might also be present on segment 7 . 


\section{Material examined}

\section{Holotype}

SOUTH CAROLINA • 1 क; Georgetown, North Inlet Estuary, Clambank docks; $33^{\circ} 20^{\prime} \mathrm{N}, 079^{\circ} 11^{\prime} \mathrm{W}$; $<1$ m b.s.1.; 19 Mar. 1975; W. Sikora leg.; from the hydroid Eudendrium sp.; USNM-54397. Specimen mounted for LM.

\section{Paratypes}

SOUTH CAROLINA • 4 우, 4 §ð’; same collection data as for holotype; USNM-54399 to 54400. Specimens mounted for LM.

Most of the types were in good condition, although the mounting medium was partly or fully dried out. While it was easy to see spines and tubes, it was very difficult or impossible to see the mostly subcuticular structures, such as glandular cell out type 1, female papillae and sensory spots. SEM specimens were not available. See Table 1 for an overview.

\section{Description}

The appearance of the species generally follows the description provided by Higgins (1977b), hence the following notes only provide additional information not included in the original description.

Males and females with minute laterodorsal glandular cell outlets type 2 on segment 8 (Fig. 8C). Spines and tubes as described by Higgins (1977b). Glandular cell outlets type 1 present in middorsal positions on segments 1 to 3,10 (two longitudinally aligned) and 11, in subdorsal positions on segments 4 to 9 , in sublateral positions on segment 1 , and ventromedial positions on segments 2 to 10 (most of these structures are also included in the original description, but generally referred to as 'sensory spots'). Actual sensory spots were only observed in paradorsal positions on segments 6 to 8 , but more sensory spots are most likely present. Female papillae are present in ventromedial positions on segment 8 (Fig. 8F). The intracuticular substructures indicate the presence of a very weak crescentic line, and a more distinct tube extending from the centre of this line. Higgins (1977b) also reports these structures but refers to them as "bracket-shaped muscle scars". He does not mention that they are restricted to females, but we can confirm that this is the case. Higgins (1977b) furthermore reports the present of "bracket-shaped muscle scars" in ventrolateral positions of segment 7 . This suggests that female papillae also could be present on this segment. We cannot confirm their presence, but this is most likely due to the age and condition of the type specimens. Hence, based on own observations and information provided by Higgins (1977b) we find it likely that female papillae are present in ventrolateral positions of segment 7 and ventromedial positions of segment 8. Laterodorsal tubes on segment 10 are quite long and slender (Fig. 8I). Tergal extensions of segment 11 are well-spaced and pointed (Fig. 8I). Lateral terminal spines are regular acicular, and gradually tapered towards tips.

Echinoderes worthingi Zelinka, 1928

Figs 16-17; Table 13

\section{Emended diagnosis}

Echinoderes with middorsal spines on segments 4 to 8, and lateroventral spines on segments 6 to 9; middorsal spines on segments 4 to 6 are barely reaching posterior segment margins of respective segments, whereas middorsal spine on segment 8 is more than twice as long as any other middorsal spine, extending to the posterior margin of segment 9 or onto segment 10 . Tubes present in lateroventral positions on segments 2 and 5, and in laterodorsal positions on 10. Glandular cell outlets type 2 not present. Paradorsal glandular cell outlets type 1 on segment 11. Primary pectinate fringe on ventral sides of segments 1 to 3 very well-developed, in particular on segment 1 . Tergal extensions of segment 11 
pointed, with tips extending into long, seta-like fringe. Females with ventromedial female papillae formed by conspicuously strong spatulate tubular substructures on segments 7 and 8 .

\section{Material examined}

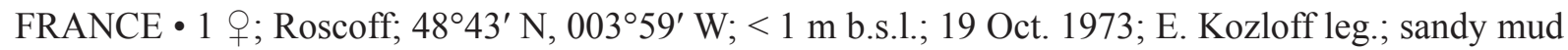
(see Higgins 1985); USNM-96034. Specimen mounted for LM.

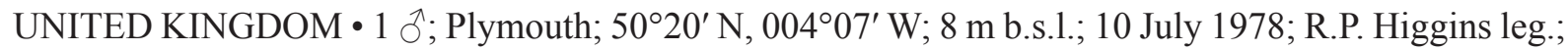
sandy mud (see Higgins 1985); USNM-67282. Specimen mounted for LM.

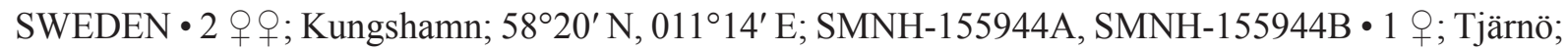
$58^{\circ} 51^{\prime} \mathrm{N}, 011^{\circ} 09^{\prime} \mathrm{E}$; 2004; G. Giribet leg.; NHMD-644455. Specimens mounted for LM.

DENMARK • 1 क ; Hirsholmene; 57 29'17" N, 010³8'01" E; < 10 m b.s.1.; 28 Jan. 2001; M.V. Sørensen leg.; shell gravel; NHMD-644454. Specimen mounted for LM.

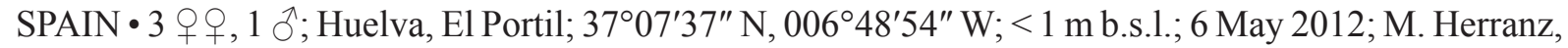
N. Sánchez and F. Pardos leg.; rocks and stones; personal reference collection of M. Herranz. Specimens mounted for SEM.

No type material was available. See Table 1 for an overview.

\section{Description}

The appearance of the species generally follows the redescription provided by Higgins (1985), hence the following notes only provide additional information not included in the original description. We could confirm the lack of glandular cell outlets type 2 in this species. Spines and tubes as described by Higgins (1985), with the conspicuously long middorsal spine on segment 8 that extends to the posterior margin of segment 9, or onto segment 10 (Figs 16F, 17B). Pectinate fringes on the posterior segment margins on segments 1 to 3 are differentiated into a dorsal half with very minute fringe tips, and a ventral half with long and well-developed fringe tips; especially on segment 1 (Fig. 17C-D). On segment 4, all fringe tips are well-developed, except in the laterodorsal parts of the margin, and fringes are well-developed all around the segment margins from segments 5 to 10 . Glandular cell outlets type 1 present in middorsal positions on segments 1 to 3 (Fig. 16B) and 10 (Fig. 16I) (two longitudinally aligned), in subdorsal positions on segments 4 to 9 (Fig. 16D-F), in sublateral positions on segment 1 (Fig. 16C), and ventromedial positions on segments 2 to 10 (most of these structures are also included in the original description, but generally referred to as 'subcuticular scars'). An additional, not previously reported pair of paradorsal glandular cell outlets type 1 is present on segment 11 (Fig. 16I). Sensory spots were easily observed in most specimens (Figs 16B, D, F, I, 17A, C-F, H). Their positions are summarized in Table 13. Female papillae are present in ventromedial positions on segments 7 (more lateral) and 8 (more midventral) (Figs 16E, 17E). They consist of circular openings, resembling glandular cell outlets type 2 (Fig. 17E), and rather strong oblique, spatulate tubular intracuticular substructures (Fig. 16G-H). The female from Roscoff (USNM-96034) is a preadult with a very thin cuticle, which explains why Higgins (1985) missed these structures. They are, however, very distinct in the Kattegat specimens (Fig. 16G-H). Hair-patterns are as described by Higgins (1985), but opposite to this redescription, perforation sites are usually distinct (expect for the preadult from Roscoff). Laterodorsal tubes on segment 10 are quite long and slender (Figs 16I-J, $17 \mathrm{G}-\mathrm{H})$. Tergal extensions of segment 11 pointed, and extending into long, flexible seta-like tips, formed by a terminal fringe (Figs $16 \mathrm{I}-\mathrm{J}, 17 \mathrm{G}-\mathrm{H}$ ). Sternal extensions rounded, without any particular fringe differentiation (Figs 16K, 17H). 


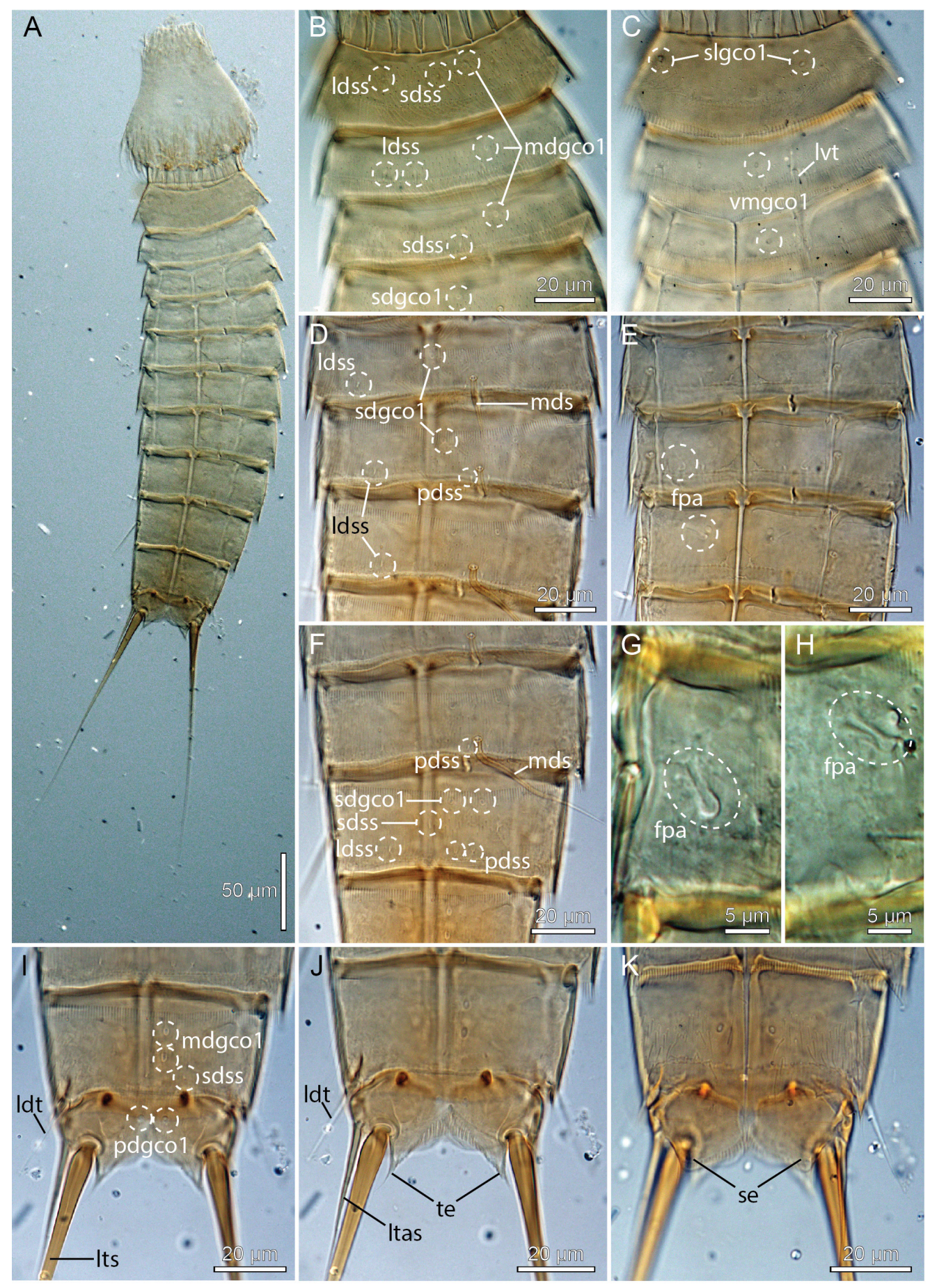

Fig. 16. Light micrographs showing overviews and details of females Echinoderes worthingi Zelinka, 1928. A-F, I-K. Specimen NHMD-644454. G-H. Specimen SMNH-155944A. A. Ventral overview. B. Segments 1 to 3, dorsal view. C. Segments 1 to 3, ventral view. D. Segments 6 to 8, dorsal view. E. Segments 6 to 8 , ventral view, showing female sexual dimorphism. F. Segments 8 to 9 , dorsal view. G. Detail showing ventromedial female papilla on left sternal of segment 7. H. Detail showing ventromedial female papilla on left sternal of segment 8. I. Segments 10 to 11, dorsal view, showing female sexual dimorphism. J. Segments 10 to 11, focused on tergal extensions and female sexually dimorphic lateral terminal accessory spines. K. Segments 10 to 11, ventral view, showing female sexual dimorphism. 

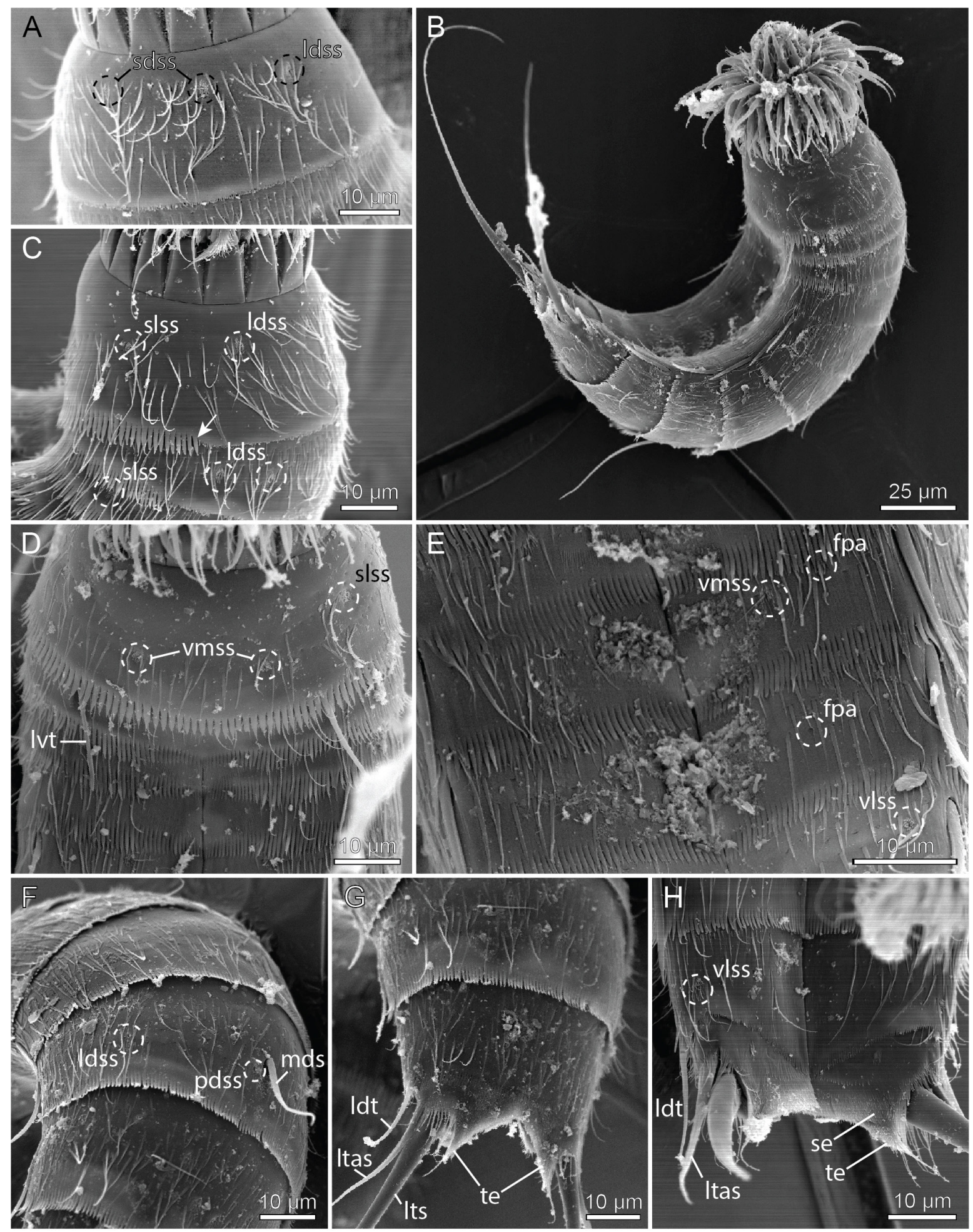

Fig. 17. Light micrographs showing overviews and details of female Echinoderes worthingi Zelinka, 1928 (MH, personal reference collection). A. Segment 1, subdorsal view. B. Lateral overview. C. Segments 1 to 2, lateral view; note how the lengths of the pectinate fringe tips change in midlateral position (arrow). D. Segments 1 to 4, ventral view. E. Segments 7 to 8, ventral view, showing female sexual dimorphism. F. Segments 7 to 9 , laterodorsal view. G. Segments 9 to 11, subdorsal view, showing female sexual dimorphism. H. Segments 10 to 11, ventral view, showing female sexual dimorphism. 
Table 13. Summary of nature and location of sensory spots, glandular cell outlets, tubes and spines arranged by series in Echinoderes worthingi Zelinka, 1928.

\begin{tabular}{|c|c|c|c|c|c|c|c|c|c|c|}
\hline $\begin{array}{l}\text { Position } \\
\text { Segment }\end{array}$ & MD & PD & SD & LD & ML & SL & LA & $\mathbf{L V}$ & VL & VM \\
\hline 1 & gco1 & & ss & ss & & ss, gco 1 & & & & ss \\
\hline 2 & gcol, ss & & & ss,ss & & & & tu & & ss, gcol \\
\hline 3 & gco1 & & ss & & & ss & & & & gcol \\
\hline 4 & $\mathrm{ac}$ & & gcol & ss & & & & & & ss, gco1 \\
\hline 5 & $\mathrm{ac}$ & & gcol, ss & ss & & & & tu & & ss, gco1 \\
\hline 6 & $\mathrm{ac}$ & ss & gco1 & ss & & & & $\mathrm{ac}$ & & ss, gco1 \\
\hline 7 & $\mathrm{ac}$ & ss & gcol & ss & & & & $\mathrm{ac}$ & & ss, fpa ( $(+)$, gco 1 \\
\hline 8 & $\mathrm{ac}$ & ss & gcol & ss & & & & $\mathrm{ac}$ & & gco1, fpa (ㅇ) \\
\hline 9 & & ss & gco1, ss & ss & & & si & $\mathrm{ac}$ & ss & gcol \\
\hline 10 & gco1, gco1 & & ss & tu & & & & & ss & gco1 \\
\hline 11 & & gcol & & & $\left.3 x p e()^{\pi}\right)$ & & $\operatorname{ltas}(+9)$ & lts & & ss \\
\hline
\end{tabular}

\section{Species revisions}

Echinoderes lanceolatus Chang \& Song, 2002

Fig. 18

\section{Material examined}

\section{Holotype}

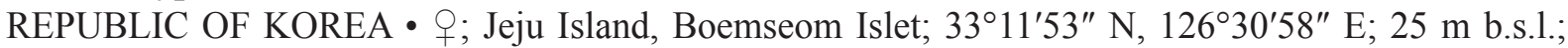
3 Mar. 2000; J. Lee and Y.H. Song leg.; muddy sand; EWNHM60268. Specimen mounted for LM.

\section{Additional material}

Additional examined material included all specimens listed as "additional material examined" in Chang \& Song (2002: 206). This material was collected from other islands in the Korean East Sea, along the south coast of the Korean Peninsula, and around Jeju Island (see further details in Table 1 and below under description of Echinoderes songae Sørensen \& Chang sp. nov.).

\section{Morphological notes on female holotype}

Specimen with slender middorsal spines on segments 4 to 8 , and lateroventral spines on segments 6 to 9; middorsal spine on segment 6 reaches posterior segment margin, whereas middorsal spines on segments 7 and 8 reach well beyond their respective posterior margins (Fig. 18B). Tubes present in ventrolateral positions on segment 2 (Fig. 18D) and lateroventral positions on 5, and in midlateral positions on 10. An incomplete midventral, intracuticular fissure is present on anterior half of segment 2 (Fig. 18D). Complete overview of glandular cell outlets type 1 distribution could not be obtained, but we see indications of paradorsal outlets on segment 6 . Glandular cell outlets type 2 are not present on any segment (Fig. 18E). Female lateral terminal accessory spines are short, with stout bases. Female papillae were difficult to examine, but indications of ventrolateral papillae with a tubular substructure were observed on segment 7 (Fig. 18C). All characters that could be observed fit the emended diagnosis of $E$. aureus, which suggest that $E$. lanceolatus is a junior synonym of this species. 


\section{Morphological notes on additional material}

All examined paratypes and non-types supposed to represent the morphology of E. lanceolatus were similar, but differed from the holotype of E. lanceolatus. The specimens have short middorsal spines on segments 4 to 8 , and lateroventral spines on segments 6 to 9 ; middorsal spines never reach the pectinate fringes of the posterior margins of their segments - not even middorsal spines on more posterior segments. Tubes are present in lateroventral positions on segments 2 and 5, and in laterodorsal positions on 10. Minute glandular cell outlets type 2 are present in laterodorsal positions on segments 8 , but lacking on segment 9. Tergal extensions of segment 11 are short, pointed and well-spaced, whereas sternal extensions are short and triangular, but not as pointed as the tergal ones. Seta-like, ventrolateral
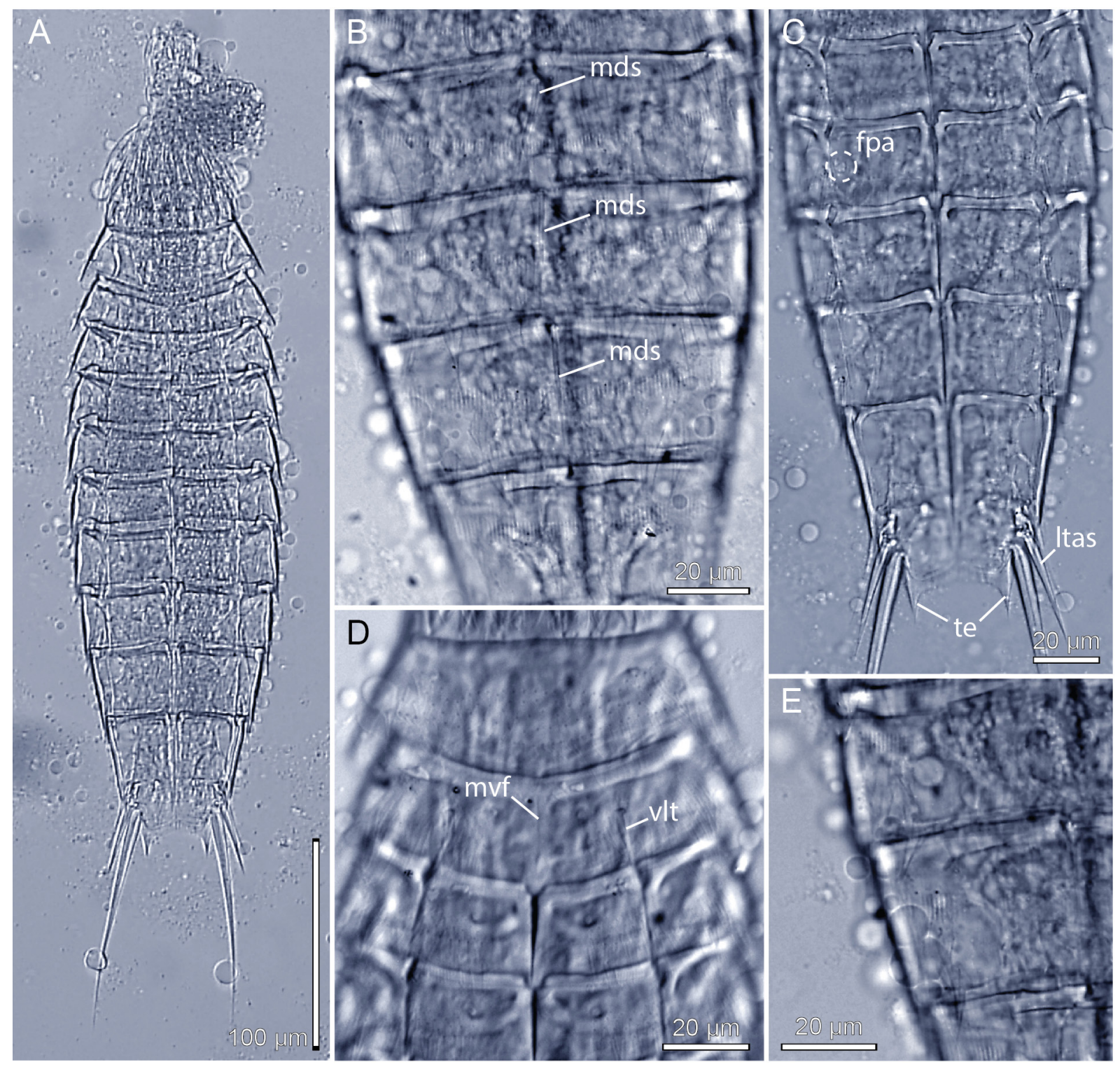

Fig. 18. Light micrographs showing overviews and details of Echinoderes lanceolatus Chang \& Song, 2002, holotype, + (EWNHM60268), species now junior synonym of Echinoderes aureus Adrianov et al., 2002. A. Ventral overview. B. Segments 7 to 10, dorsal view. C. Segments 6 to 11, ventral view. D. Segments 1 to 4 , ventral view. E. Details showing laterodorsal and midlateral parts of segments 8 and 9 , documenting the absence of glandular cell outlet type 2 . 
tufts of extended fringe tips project from the sternal extensions. Females have slender lateral terminal accessory spines, and female papillae with tubular intracuticular substructure in ventrolateral positions on segments 7 and in ventromedial positions on segment 8 . These traits suggest that the specimens are not conspecific with the holotype of E. lanceolatus, but represent a new species (see following description of E. songae Sørensen \& Chang sp. nov.).

\title{
Description of new species
}

\author{
Echinoderes songae Sørensen \& Chang sp. nov. \\ urn:1sid:zoobank.org:act:7C168528-B97E-4D7E-A725-4C74B4C0D2BF
}

Figs 19-21; Tables 14-16

Echinoderes lanceolatus - Chang \& Song 2002: 204, 206.

Echinoderes sp. A - Yamasaki et al. 2014: 421-428, figs 1, 3, tables 1, 4-5.

\section{Diagnosis}

Echinoderes with short middorsal spines on segments 4 to 8 , and lateroventral spines on segments 6 to 9 ; middorsal spine on segment 8 reaches the pectinate fringe of its posterior margin, but does not extend beyond it. Tubes present in lateroventral positions on segments 2 and 5, and in midlateral positions on 10. Minute glandular cell outlets type 2 in midlateral positions on segment 8 . Tergal extensions of segment 11 short, pointed and well-spaced; sternal extensions short, with ventrolateral seta-like tuft of extended fringe tips. Both sexes with ventrolateral sensory spots on segment 10, but sensory spots in females are located closer to the posterior segment margin. Females with female papillae showing indistinct crescentic intracuticular substructure in ventrolateral positions on segments 7 and with tubular to rhomboid substructure in ventromedial positions on segment 8 .

\section{Etymology}

The species is dedicated to Dr Young Hee Song who co-authored the description of Echinoderes lanceolatus Chang \& Song, 2002, and assisted during collecting of much of the material used for the present description.

\section{Material examined}

Holotype

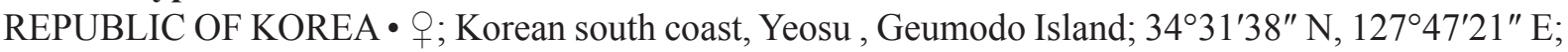
0 m b.s.l.; 16 Jun. 2000; C.Y. Chang, J. Lee and Y.H. Song leg.; intertidal macroalgae; NHMD-662101. Specimen mounted for LM in Hoyer's medium.

\section{Paratypes}

Paratypes include 22 specimens, collected from a total of 18 localities around the Korean Peninsula, and all mounted as the holotype. 11 paratypes, four females and seven males, are deposited at NHMD under catalogue numbers NHMD-662102 to 662102. Another 11 paratypes, two females and nine males, are deposited at NIBR under catalogue numbers NIBRIV0000866873 to NIBRIV0000866883.

\section{Additional material}

Additional LM material includes three non-types, stored in the personal reference collection of C.Y. Chang. Material mounted for SEM includes nine females and thirteen males from five different localities; SEM material stored in the personal reference collection of M.V. Sørensen. Further species, not used in the description but with identity confirmed as E. songae Sørensen \& Chang sp. nov., were collected by $\mathrm{H}$. Yamasaki and included as Echinoderes sp. A in his population genetic study of Echinoderes species across the Tsugaru Strait in Northern Japan (Yamasaki et al. 2014). See Table 1 for 
a summary of studied material, and Table 14 for a detailed overview of stations yielding types or nontypes for the description.

\section{Description}

Adults with head, neck and eleven trunk segments (Figs 19A-B, 20A, 21A). Secondary pectinate fringe present near anterior segment margin of segments 2 to 10 . For complete overview of measurements and dimensions, see Table 15. Distribution of cuticular structures, i.e., sensory spots, glandular cell outlets, spines and tubes, is summarized in Table 16.

The head consists of a retractable mouth cone and an introvert (Fig. 21B). Mouth cone with ten helioscalids; other inner oral styles could not be examined in detail. The external mouth cone armature consists of nine outer oral styles; bases of outer oral styles each with a transverse row of short fringe tips; two central, distally bifurcated bristles are present more posteriorly. The introvert sectors are defined by the ten primary spinoscalids in Ring 01 . Each primary spinoscalid consists of a basal sheath and a distal end piece with a blunt tip. The sheaths have a well-defined basal, transverse fringe, overhanging a second, more distal transverse fringe. End pieces are smooth and flexible. Rings 02 and 04 have 10 spinoscalids and Rings 03 and 05 have 20. All spinoscalids in these rings are well-developed, and consist of a basal sheath and a pointed end piece. The basal sheaths terminate into fine, fringed margins in spinoscalids of Rings 02 to 05 , and those of Rings 03 to 05 have in addition a basal median spike also. Ring 06 has only six spinoscalids, located in sectors 1,3,5, 6, 7, and 9; Ring 06 spinoscalids resemble those in preceding sectors, but without a distinct differentiation into sheath and end piece. Ring 07 also has 6 spinoscalids, located as pairs in sectors 3 and 9, and unpaired but laterally displaced in sectors 5 and 7 (trichoscalids are taking up the space in the opposite side of each sector); ring 07 spinoscalids resemble those in preceding sector.

Described sector-wise, sectors 1 and 6 are similar, having spinoscalids arranged as two double diamonds anterior. Sectors 2, 4, 8 and 10 all have spinoscalids arranged as a quincunx, located in between a medial anterior spinoscalid (Ring 02) and a trichoscalid plate. Sectors 3 and 9 have spinoscalids forming double diamonds anterior to a pair of spinoscalids. Sectors 5 and 7 also have spinoscalids forming double diamonds, but anterior to an unpaired, laterally spinoscalid (see Fig. 13 for species with similar outer oral style and scalid pattern).

Regular trichoscalids with trichoscalid plates are present in sectors $2,4,5,7,8$, and 10. In addition, a single trichoscalid without trichoscalid plate is present in sector 1 .

The neck has 16 placids, measuring $13 \mu \mathrm{m}$ in length. The midventral placid is broadest, measuring $12 \mu \mathrm{m}$ in width at its base, whereas all other are narrower, measuring $7 \mu \mathrm{m}$ in width at their bases. The trichoscalid plates are well-developed, subdorsal and laterodorsal ones narrow and elongated, and ventromedial ones broadly oval.

Segment 1 consists of a complete cuticular ring. Sensory spots are located on the anterior segment half in subdorsal, laterodorsal, and sublateral positions, and slightly more posterior in ventromedial positions (Figs 19A-B, 21C-E); sensory spots are large, and rounded to oval, with numerous micropapillae, two pores, and often a cilium emerging from one of the pores. Glandular cell outlets type 1 present in middorsal and lateral accessory positions (Figs 19A-B, 20B-C, 21C). Dorsal and lateral sides, and posterior half of ventral side, with scattered cuticular hairs emerging through rounded perforation sites. The posterior segment margin is straight around the segment, terminating into a pectinate fringe with short, uniform fringe tips. 

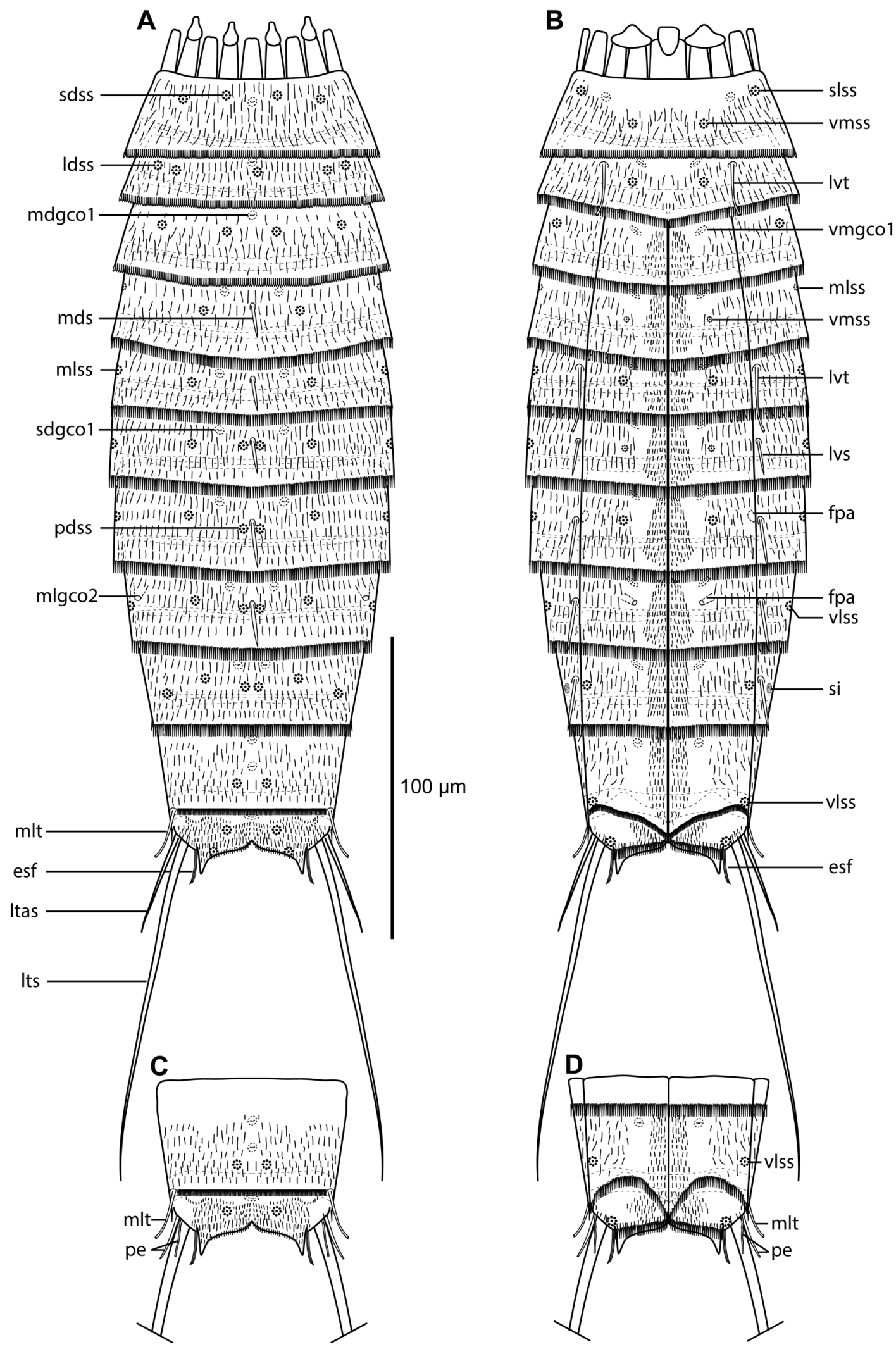

Fig. 19. Line art illustrations of Echinoderes songae Sørensen \& Chang sp. nov. A. Female, dorsal view. B. Female, ventral view. C. Segments 10 to 11 in male, dorsal view. D. Segments 10 to 11 in male, ventral view. 
Segment 2 consists of a complete cuticular ring. Pachycyclus of the anterior segment margin is of medium thickness and not interrupted (Fig. 20B-C). Sensory spots are located in middorsal (but slightly laterally displaced), laterodorsal (twin pair) and ventromedial positions (Figs 19A-B, 21C-E); sensory spots on this and all following segments rounded, but with less papillae than on segment 1. Glandular cell outlets type 1 present in middorsal and ventromedial positions, and long and slender tubes present in lateroventral positions (Figs 19A-B, 20B-C, 21C-E). The segment is densely covered with bracteate hairs, but interrupted by hairless areas anterior to laterodorsal sensory spots and posterior to lateroventral tubes (Fig. 21C-E). The posterior segment margin is nearly straight; pectinate fringe from middorsal to midlateral positions with short fringe tips, as on segment 1 ; fringe tips from midlateral to ventromedial positions conspicuously longer and with trifurcate tips (two short lateral tips, and a long medial tip), and then slightly shorter but still trifurcate between ventromedial positions.

Segment 3, and remaining segments, consisting of one tergal and two sternal plates. Pachycyclus of the anterior segment margin of medium thickness, and interrupted only at tergosternal junctions. Sensory spots present in subdorsal, laterodorsal and sublateral positions (Figs 19A-B, 21C). Glandular cell outlets type 1 present in middorsal and ventromedial positions (Figs 19A-B, 20B-C). Bracteate cuticular hairs are densely covering the segment from middorsal to ventromedial positions (except in a hairless V-shaped patch anterior on segment in laterodorsal positions); paraventral areas densely covered by non-bracteate, hair-like extensions. Pectinate fringe of posterior margin hairs as on preceding segment, but with ventromedial fringe tips being slightly longer.

Segment 4 with short acicular spine in middorsal position, not reaching the posterior margin of the segment (Figs 19A, 21F); this and all middorsal spines on following segments with finely serrated lateral edges. Sensory spots present in subdorsal, midlateral and ventromedial positions (Figs 19A-B, 21F); midlateral and ventromedial sensory spots considerably smaller than all other sensory spots in the species, but they occur consistently in all examined specimens. Glandular cell outlets type 1 present in subdorsal and ventromedial positions (Figs 19A-B, 20E). Pectinate fringe of posterior segment margin with long fringe tips from middorsal to ventromedial positions, and with only slightly shorter tips between ventromedial positions. Pachycycli and cuticular hairs as on preceding segment.

Segment 5 with short acicular spine in middorsal position (Figs 19A, 21F), not reaching the posterior margin of the segment, and long, slender tubes in lateroventral positions (Figs 19B, 20E, 21H). Sensory spots present in subdorsal, midlateral and ventromedial positions (Figs 19A-B, 21F). Pectinate fringe of posterior segment margin with equally long fringe tips around the segment. Glandular cell outlets type 1 , pachycycli, and cuticular hairs as on preceding segment.

Segment 6 with short acicular spines in middorsal and lateroventral positions (Figs 19A-B, 20E, 21F, $\mathrm{H}$ ), not reaching the posterior margin of the segment; lateral edges of lateroventral spines on this following segments with stronger serration. Sensory spots present in paradorsal, subdorsal, midlateral and ventromedial positions (Figs 19A-B, 21F, H). Glandular cell outlets type 1, pachycycli, pectinate fringe of posterior margin and cuticular hairs as on preceding segment.

Segment 7 with short acicular spines in middorsal and lateroventral positions (Figs 19A-B, 20D-E, $21 \mathrm{H})$, barely or just reaching the posterior margin of the segment. Females with female papillae in ventrolateral positions (Figs 19B, 20E, G, 21H); openings of papillae with fine fringes around their margins (Fig. $21 \mathrm{H}$ ); intracuticular substructures each form an indistinct crescentic structure, but without a clearly visible protuberance in the curved part (Fig. 20G). Sensory spots, glandular cell outlets type 1, pachycycli, pectinate fringe of posterior margin and cuticular hairs as on preceding segment.

Segment 8 with short acicular spines in middorsal and lateroventral positions (Figs 19A-B, 20D, F-G), barely or just reaching the posterior margin of the segment. Minute glandular cell outlets type 2 present 

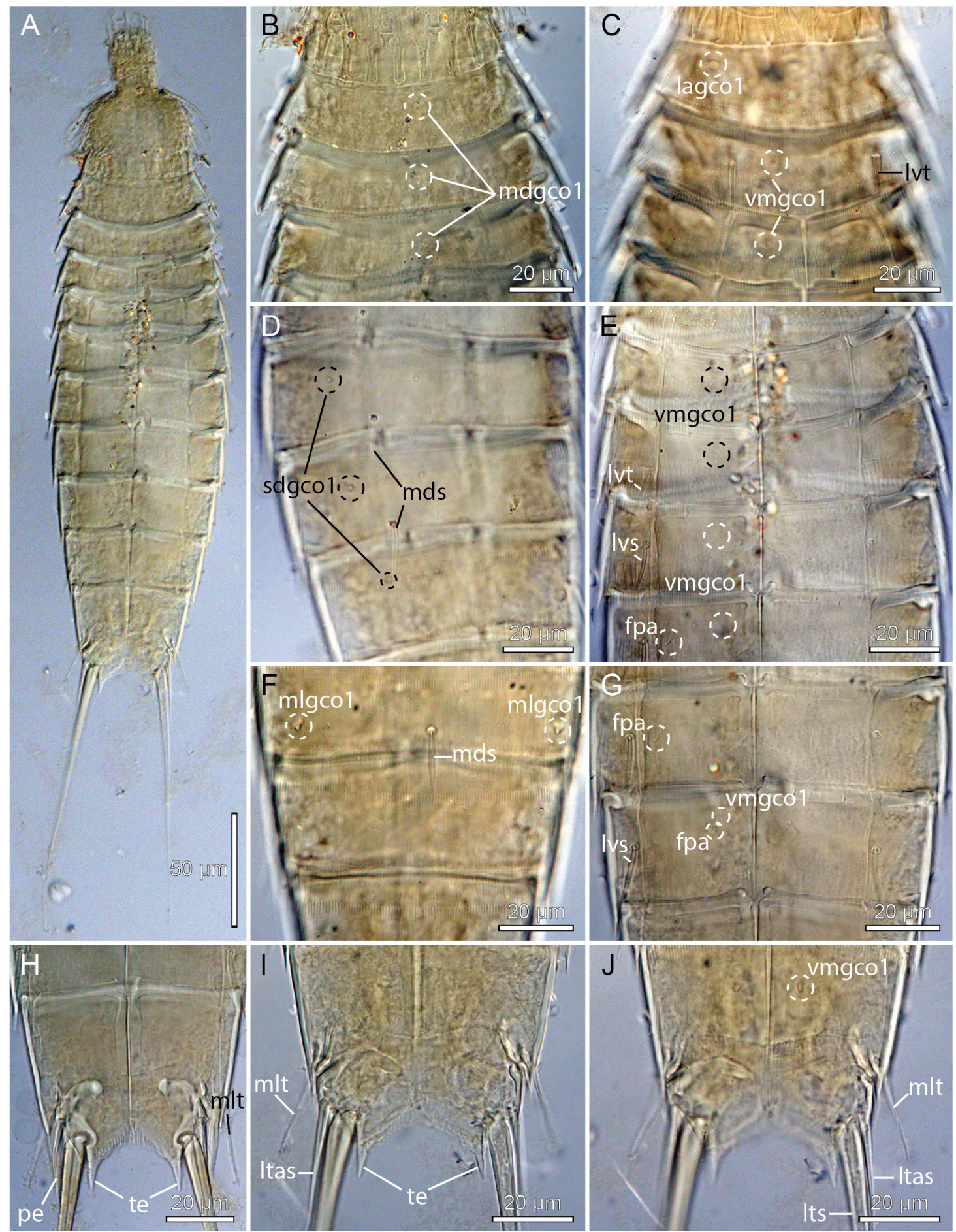

Fig. 20. Light micrographs showing overviews and details of Echinoderes songae Sørensen \& Chang

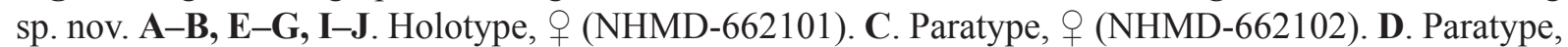
o (NHMD-662103). H. Paratype, ô (NHMD-662104). A. Ventral overview. B. Segments 1 to 3, dorsal view. C. Segments 1 to 3, ventral view. D. Segments 7 to 9, dorsal view. E. Segments 4 to 7, ventral view, showing female sexual dimorphism. F. Segments 8 to 9 , dorsal view. G. Segments 7 to 8 , ventral view, showing female sexual dimorphism. H. Segments 10 to 11 , ventral view, showing male sexual dimorphism. I. Segments 10 to 11, dorsal view, showing female sexual dimorphism. J. Segments 10 to 11 , ventral view, showing female sexual dimorphism. 

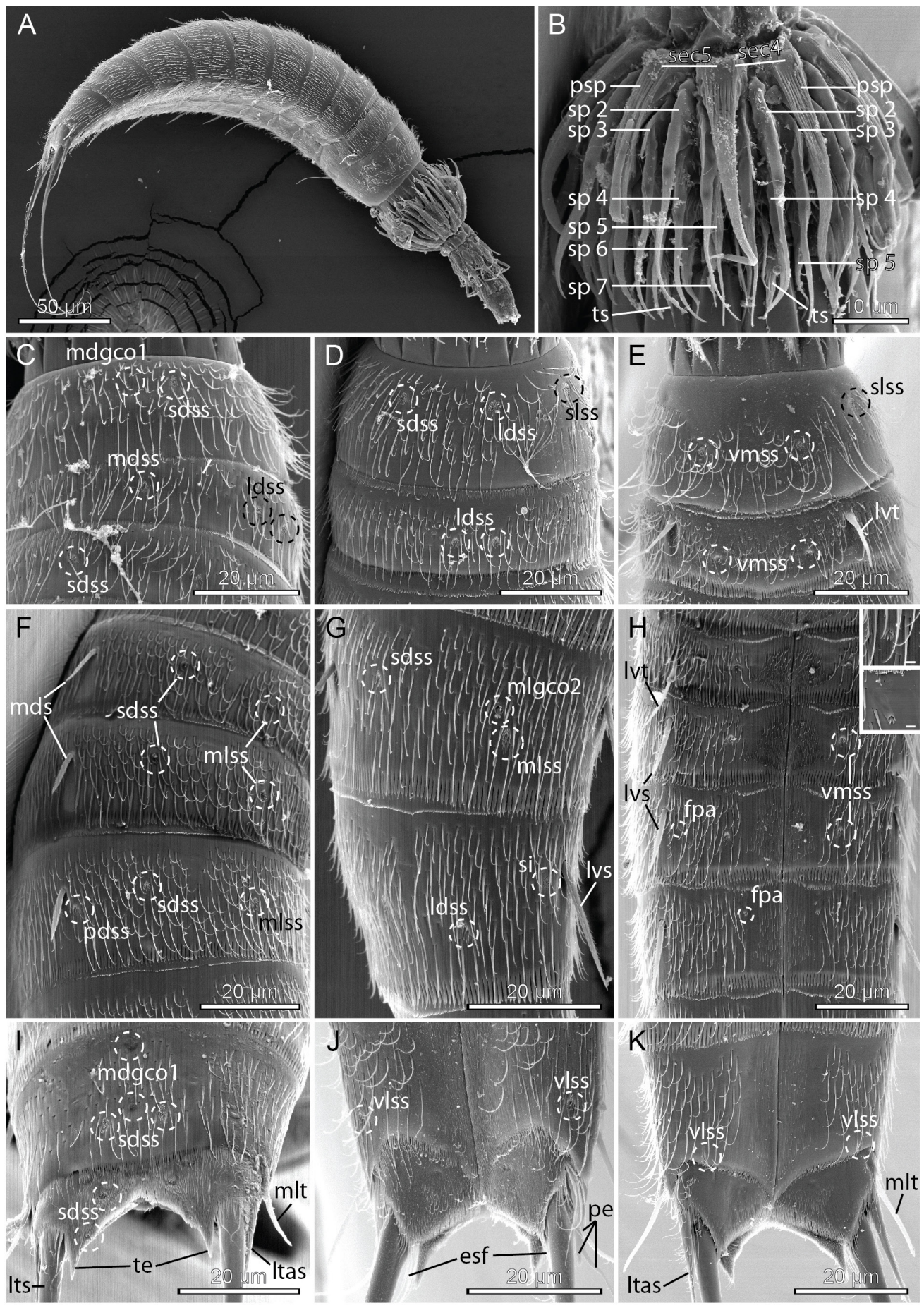

Fig. 21. Scanning electron micrographs showing overviews and details of Echinoderes songae Sørensen \& Chang sp. nov. A-B, D, F-I, K. क (MVS, personal reference collection). C, E, J. $\widehat{\sigma}$ (MVS, personal reference collection). A. Lateroventral overview. B. Introvert sectors 5 and 4 (laterodorsal). C. Segments 1 to 3, dorsal view. D. Segments 1 to 2, laterodorsal view. E. Segments 1 to 2, ventral view. F. Segments 4 to 6 , laterodorsal view. G. Segments 8 to 9, lateral view; inset show glandular cell outlets type 2 . H. Segments 5 to 8, ventral view, showing female sexual dimorphism; insets show outlets of female papillae on segment 7 (upper inset) and segment 8 (lower inset), scale on insets $=1 \mu \mathrm{m}$. I. Segments 10 to 11 , dorsal view, showing female sexual dimorphism. J. Segments 10 to 11 ventral view, showing male sexual dimorphism. K. Segments 10 to 11 ventral view, showing female sexual dimorphism. 
Table 14 (continued on next page). Summary of collecting data for Echinoderes songae Sørensen \& Chang sp. nov. Type locality boldfaced. Initials of collectors: CYC $=$ C.Y. Chang; HSR = H.S. Rho; HY $=$ Hiroshi Yamasaki; JL = J. Lee; SHK = S.H. Kim; SKP = S.K. Paik; YHS = Y.H. Song.

\begin{tabular}{|c|c|c|c|c|c|c|c|}
\hline Station & Date & Locality name & Position & Depth & Substrate & Collectors & $\begin{array}{l}\text { Type status and } \\
\text { catalogue numbers }\end{array}$ \\
\hline \multicolumn{8}{|c|}{ LM material: types and non-types } \\
\hline CYC-1 & Oct. 6,2000 & $\begin{array}{l}\text { Namae, Korean east } \\
\text { coast }\end{array}$ & $\begin{array}{l}37^{\circ} 56^{\prime} 48^{\prime \prime} \mathrm{N} \\
128^{\circ} 47^{\prime} 08^{\prime \prime} \mathrm{E}\end{array}$ & Intertidal & $\begin{array}{l}\text { Algae and } \\
\text { macroinvertebrates }\end{array}$ & CYC, YHS & $\begin{array}{l}1 \text { q paratype, } \\
\text { NHMD-662102 }\end{array}$ \\
\hline CYC-2 & Nov. 5, 1999 & $\begin{array}{l}\text { Youngjin, Gangreung, } \\
\text { Korean east coast }\end{array}$ & $\begin{array}{l}37^{\circ} 52^{\prime} 04^{\prime \prime} \mathrm{N} \\
128^{\circ} 50^{\prime} 53^{\prime \prime} \mathrm{E}\end{array}$ & Intertidal & Algae & JL, YHS & $\begin{array}{l}1 \text { q paratype, } \\
\text { NHMD-662103 }\end{array}$ \\
\hline CYC-3 & Nov. 5, 1999 & $\begin{array}{l}\text { Geumjin, Gangreung, } \\
\text { Korean east coast }\end{array}$ & $\begin{array}{l}37^{\circ} 39^{\prime} 08^{\prime \prime} \mathrm{N} \\
129^{\circ} 03^{\prime} 00^{\prime \prime} \mathrm{E}\end{array}$ & Intertidal & Hermit crab & $\begin{array}{l}\text { CYC, JL, } \\
\text { YHS }\end{array}$ & $\begin{array}{l}2 \text { 우 paratypes, } \\
\text { NHMD-662104- } \\
662105\end{array}$ \\
\hline CYC-4 & Oct. 9, 1999 & $\begin{array}{l}\text { Gungchon, Samcheok, } \\
\text { Korean east coast }\end{array}$ & $\begin{array}{l}37^{\circ} 19^{\prime} 37^{\prime \prime} \mathrm{N} \\
129^{\circ} 16^{\prime} 08^{\prime \prime} \mathrm{E}\end{array}$ & Intertidal & Ascidians & JL, YHS & $\begin{array}{l}1 \text { \& paratype, } \\
\text { NIBRIV0000866873 }\end{array}$ \\
\hline CYC-6 & May 12, 1999 & $\begin{array}{l}\text { Dokdo/Takeshima } \\
\text { Islands }\end{array}$ & $\begin{array}{l}37^{\circ} 14^{\prime} 31^{\prime \prime} \mathrm{N} \\
131^{\circ} 50^{\prime} 51^{\prime \prime} \mathrm{E}\end{array}$ & Intertidal & Algae & SHK & $\begin{array}{l}1 \delta \text { paratype, } \\
\text { NHMD-662106 }\end{array}$ \\
\hline CYC-7 & Oct. 8, 1999 & $\begin{array}{l}\text { Geoil, Uljin, Korean } \\
\text { east coast }\end{array}$ & $\begin{array}{l}36^{\circ} 42^{\prime} 35^{\prime \prime} \mathrm{N} \\
129^{\circ} 28^{\prime} 32^{\prime \prime} \mathrm{E}\end{array}$ & Intertidal & Algae & $\begin{array}{l}\text { CYC, JL, } \\
\text { YHS }\end{array}$ & $\begin{array}{l}1 \delta \text { paratype, } \\
\text { NHMD-662107 }\end{array}$ \\
\hline CYC-8 & Sep. 26, 1998 & $\begin{array}{l}\text { Geumjin, Yeongdeok, } \\
\text { Korean east coast }\end{array}$ & $\begin{array}{l}36^{\circ} 22^{\prime} 06^{\prime \prime} \mathrm{N} \\
129^{\circ} 23^{\prime} 46^{\prime \prime} \mathrm{E}\end{array}$ & Intertidal & Polychaete tubes & CYC, HSR & $\begin{array}{l}1 \text { o paratype, } \\
\text { NIBRIV0000866874 }\end{array}$ \\
\hline CYC-9 & Nov. 24, 1997 & $\begin{array}{l}\text { Odo-ri, Pohang, } \\
\text { Korean east coast }\end{array}$ & $\begin{array}{l}36^{\circ} 09^{\prime} 15^{\prime \prime} \mathrm{N} \\
129^{\circ} 24^{\prime} 02^{\prime \prime} \mathrm{E}\end{array}$ & Subtidal & Macroinvertebrates & CYC, HSR & $\begin{array}{l}2 \precsim \hat{\jmath} \text { paratypes, } \\
\text { NIBRIV0000866875, } \\
\text { NIBRIV0000866876 }\end{array}$ \\
\hline CYC-10 & Nov. 1, 1999 & $\begin{array}{l}\text { Imgok, Pohang, } \\
\text { Korean east coast }\end{array}$ & $\begin{array}{l}35^{\circ} 59^{\prime} 55^{\prime \prime} \mathrm{N} \\
129^{\circ} 27^{\prime} 26^{\prime \prime} \mathrm{E}\end{array}$ & Intertidal & Algae & $\begin{array}{l}\text { CYC, JL, } \\
\text { YHS }\end{array}$ & $\begin{array}{l}1 \text { q paratype, } \\
\text { NHMD-662108 }\end{array}$ \\
\hline CYC-11 & May 29, 1999 & $\begin{array}{l}\text { Sinchang, Pohang, } \\
\text { Korean east coast }\end{array}$ & $\begin{array}{l}35^{\circ} 53^{\prime} 08^{\prime \prime} \mathrm{N} \\
129^{\circ} 31^{\prime} 43^{\prime \prime} \mathrm{E}\end{array}$ & Intertidal & Algae & $\begin{array}{l}\text { CYC, JL, } \\
\text { YHS }\end{array}$ & $\begin{array}{l}1 \delta \text { paratype, } \\
\text { NHMD-662109 }\end{array}$ \\
\hline CYC-13 & Dec. 3, 1999 & $\begin{array}{l}\text { Daewangam, Ulsan, } \\
\text { Korean east coast }\end{array}$ & $\begin{array}{l}35^{\circ} 29^{\prime} 31^{\prime \prime} \mathrm{N} \\
129^{\circ} 26^{\prime} 44^{\prime \prime} \mathrm{E}\end{array}$ & Intertidal & Algae & CYC, HSR & $\begin{array}{l}1 \text { o paratype, } \\
\text { NIBRIV0000866877 }\end{array}$ \\
\hline CYC-14 & Dec. 12,1999 & $\begin{array}{l}\text { Ilgwang, Busan, } \\
\text { Korean east coast }\end{array}$ & $\begin{array}{l}35^{\circ} 15^{\prime} 52^{\prime \prime} \mathrm{N} \\
129^{\circ} 14^{\prime} 14^{\prime \prime} \mathrm{E}\end{array}$ & Intertidal & Algae & JL, YHS & $\begin{array}{l}1 \text { q, } 1 \text { ð paratypes, } \\
\text { NIBRIV0000866878, } \\
\text { NIBRIV0000866879 }\end{array}$ \\
\hline CYC-15 & Jan. 29, 1997 & $\begin{array}{l}\text { Hakdong, Geoje Island, } \\
\text { Korean south coast }\end{array}$ & $\begin{array}{l}34^{\circ} 46^{\prime} 16^{\prime \prime} \mathrm{N} \\
128^{\circ} 38^{\prime} 23^{\prime \prime} \mathrm{E}\end{array}$ & Intertidal & Algae & CYC, HSR & $\begin{array}{l}1 \text { paratype, } \\
\text { NHMD- } 662110\end{array}$ \\
\hline CYC-16 & Apr. 8, 1999 & $\begin{array}{l}\text { Jangdu Island, } \\
\text { Tongyong, Korean } \\
\text { south coast }\end{array}$ & $\begin{array}{l}34^{\circ} 46^{\prime} 02^{\prime \prime} \mathrm{N} \\
128^{\circ} 23^{\prime} 07^{\prime \prime} \mathrm{E}\end{array}$ & Subtidal & Sand & SKP & $\begin{array}{l}2 \hat{\delta} \text { paratype, } \\
\text { NIBRIV0000866880, } \\
\text { NIBRIV0000866881 }\end{array}$ \\
\hline CYC-17 & Jun. 16, 2000 & $\begin{array}{l}\text { Geumodo Island, } \\
\text { Yeosu, Korean south } \\
\text { coast }\end{array}$ & $\begin{array}{l}34^{\circ} 31^{\prime} 38^{\prime \prime} \mathrm{N} \\
127^{\circ} 47^{\prime} 21^{\prime \prime} \mathrm{E}\end{array}$ & Intertidal & Algae & $\begin{array}{l}\text { CYC, JL, } \\
\text { YHS }\end{array}$ & $\begin{array}{l}1 \text { q holotype, } \\
\text { NHMD-662101 }\end{array}$ \\
\hline CYC-18 & May 25, 2001 & $\begin{array}{l}\text { Sado Island, Yeosu, } \\
\text { Korean south coast }\end{array}$ & $\begin{array}{l}34^{\circ} 35^{\prime} 19^{\prime \prime} \mathrm{N} \\
127^{\circ} 33^{\prime} 20^{\prime \prime} \mathrm{E}\end{array}$ & - & - & $\begin{array}{l}\text { CYC, JL, } \\
\text { YHS }\end{array}$ & $\begin{array}{l}1 \delta \text { paratype, } \\
\text { NIBRIV0000866882 }\end{array}$ \\
\hline CYC-19 & Aug. 15, 1998 & $\begin{array}{l}\text { Uido Island, Sinan, } \\
\text { Korean southwest coast }\end{array}$ & $\begin{array}{l}34^{\circ} 37^{\prime} 34^{\prime \prime} \mathrm{N} \\
125^{\circ} 50^{\prime} 46^{\prime \prime} \mathrm{E}\end{array}$ & Intertidal & Oyster shells & SHK & $\begin{array}{l}1 \text { o paratype, } \\
\text { NHMD- } 662111, \\
1 \text { o non-type, } \\
\text { Chang collection }\end{array}$ \\
\hline CYC-21 & Nov. 25, 2000 & $\begin{array}{l}\text { Biando Island, Gunsan, } \\
\text { Korean west coast }\end{array}$ & $\begin{array}{l}35^{\circ} 44^{\prime} 40^{\prime \prime} \mathrm{N} \\
126^{\circ} 26^{\prime} 39^{\prime \prime} \mathrm{E}\end{array}$ & Intertidal & Algae & CYC, JL & $\begin{array}{l}1 \text { paratype, } \\
\text { NIBRIV0000866883, } \\
1 \text { non-type, } \\
\text { Chang collection }\end{array}$ \\
\hline CYC-22 & Apr. 2, 2000 & $\begin{array}{l}\text { Mongsanpo, Taean, } \\
\text { Korean west coast }\end{array}$ & $\begin{array}{l}36^{\circ} 40^{\prime} 22^{\prime \prime} \mathrm{N} \\
126^{\circ} 16^{\prime} 40^{\prime \prime} \mathrm{E}\end{array}$ & Intertidal & Oyster shells & CYC, JL & $\begin{array}{l}1 \text { ô paratype, } \\
\text { NHMD-662112, } \\
1 \text { ô non-type, } \\
\text { Chang collection }\end{array}$ \\
\hline
\end{tabular}


Table 14 (continued).

\begin{tabular}{|c|c|c|c|c|c|c|c|}
\hline Station & Date & Locality name & Position & Depth & Substrate & Collectors & $\begin{array}{l}\text { Type status and } \\
\text { catalogue numbers }\end{array}$ \\
\hline \multicolumn{8}{|c|}{ SEM material: non-types } \\
\hline CYC-28 & Oct. 11,2005 & $\begin{array}{l}\text { Jangho, Samcheok, } \\
\text { Korean east coast }\end{array}$ & $\begin{array}{l}37^{\circ} 17^{\prime} 12^{\prime \prime} \mathrm{N} \\
129^{\circ} 18^{\prime} 52^{\prime \prime} \mathrm{E}\end{array}$ & Intertidal & Sand with mussels & $\mathrm{CYC}$ & 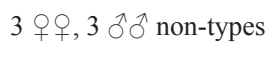 \\
\hline CYC-30 & Nov. 4, 2005 & $\begin{array}{l}\text { Daebyeon, Busan, } \\
\text { Korean east coast }\end{array}$ & $\begin{array}{l}35^{\circ} 12^{\prime} 59^{\prime \prime} \mathrm{N} \\
129^{\circ} 13^{\prime} 35^{\prime \prime} \mathrm{E}\end{array}$ & Intertidal & $\begin{array}{l}\text { Sand with gastropod } \\
\text { shells }\end{array}$ & $\mathrm{CYC}, \mathrm{JL}$ & $2 \stackrel{+}{0}, 4 \hat{\partial} \widehat{\partial}$ non-types \\
\hline CYC-31 & May 25, 2001 & $\begin{array}{l}\text { Sado Island, Yeosu, } \\
\text { Korean south coast }\end{array}$ & $\begin{array}{l}34^{\circ} 35^{\prime} 24^{\prime \prime} \mathrm{N} \\
127^{\circ} 32^{\prime} 23^{\prime \prime} \mathrm{E}\end{array}$ & Intertidal & $\begin{array}{l}\text { Rocks with algae } \\
\text { and polychaete tubes }\end{array}$ & $\mathrm{CYC}, \mathrm{JL}$ & $1 \uparrow q, 1 \hat{\jmath}$ non-types \\
\hline CYC-35 & Nov. 19, 2004 & $\begin{array}{l}\text { Changheung, Jeju } \\
\text { Island, Korea Strait }\end{array}$ & $\begin{array}{l}33^{\circ} 30^{\prime} 52^{\prime \prime} \mathrm{N} \\
126^{\circ} 54^{\prime} 07^{\prime \prime} \mathrm{E}\end{array}$ & Intertidal & Rocks with algae & $\mathrm{CYC}, \mathrm{JL}$ & $1 \uparrow, 2 \hat{\partial}$ non-types \\
\hline MAP35 & Jul. 8, 2003 & $\begin{array}{l}\text { Museum Islet, Jeju } \\
\text { Island, Korea Strait }\end{array}$ & $\begin{array}{l}33^{\circ} 13^{\prime} 40^{\prime \prime} \mathrm{N} \\
126^{\circ} 34^{\prime} 01^{\prime \prime} \mathrm{E}\end{array}$ & $37 \mathrm{~m}$ & $\begin{array}{l}\text { Mud with shell } \\
\text { fragments }\end{array}$ & HSR & $2 \nmid q$ non-types \\
\hline \multicolumn{8}{|c|}{ Non-types from H. Yamasaki reference collection } \\
\hline- & Jul. 3, 2011 & $\begin{array}{l}\text { Nemuro, Hokkaido, } \\
\text { Japan }\end{array}$ & $\begin{array}{l}43^{\circ} 23^{\prime} 16^{\prime \prime} \mathrm{N} \\
145^{\circ} 41^{\prime} 34^{\prime \prime} \mathrm{E}\end{array}$ & Intertidal & $\begin{array}{l}\text { Rocks and macroin- } \\
\text { vertebrates }\end{array}$ & $\mathrm{HY}$ & $\begin{array}{l}24 \text { DNA sequenced } \\
\text { specimens }\end{array}$ \\
\hline- & Nov. 10, 2011 & $\begin{array}{l}\text { Oshoro, Hokkaido, } \\
\text { Japan }\end{array}$ & $\begin{array}{l}43^{\circ} 12^{\prime} 38^{\prime \prime} \mathrm{N} \\
140^{\circ} 51^{\prime} 25^{\prime \prime} \mathrm{E}\end{array}$ & Intertidal & $\begin{array}{l}\text { Rocks and macroin- } \\
\text { vertebrates }\end{array}$ & HY & $\begin{array}{l}24 \text { DNA sequenced } \\
\text { specimens }\end{array}$ \\
\hline- & Jul. 2, 2011 & $\begin{array}{l}\text { Akkeshi, Hokkaido, } \\
\text { Japan }\end{array}$ & $\begin{array}{l}43^{\circ} 00^{\prime} 53^{\prime \prime} \mathrm{N} \\
144^{\circ} 49^{\prime} 53^{\prime \prime} \mathrm{E}\end{array}$ & Intertidal & $\begin{array}{l}\text { Rocks and macroin- } \\
\text { vertebrates }\end{array}$ & HY & $\begin{array}{l}24 \text { DNA sequenced } \\
\text { specimens }\end{array}$ \\
\hline- & Oct. 8,2011 & $\begin{array}{l}\text { Muroran, Hokkaido, } \\
\text { Japan }\end{array}$ & $\begin{array}{l}42^{\circ} 18^{\prime} 48^{\prime \prime} \mathrm{N} \\
140^{\circ} 58^{\prime} 05^{\prime \prime} \mathrm{E}\end{array}$ & Intertidal & $\begin{array}{l}\text { Rocks and macroin- } \\
\text { vertebrates }\end{array}$ & HY & $\begin{array}{l}23 \text { DNA sequenced } \\
\text { specimens }\end{array}$ \\
\hline- & Mar. 11, 2012 & $\begin{array}{l}\text { Tobetsu, Hokkaido, } \\
\text { Japan }\end{array}$ & $\begin{array}{l}41^{\circ} 44^{\prime} 12^{\prime \prime} \mathrm{N} \\
140^{\circ} 35^{\prime} 01^{\prime \prime} \mathrm{E}\end{array}$ & Intertidal & $\begin{array}{l}\text { Rocks and macroin- } \\
\text { vertebrates }\end{array}$ & $\mathrm{HY}$ & $\begin{array}{l}41 \text { DNA sequenced } \\
\text { specimens }\end{array}$ \\
\hline- & Sep. 12, 2011 & $\begin{array}{l}\text { Horozuki, Aomori, } \\
\text { Japan }\end{array}$ & $\begin{array}{l}41^{\circ} 13^{\prime} 35^{\prime \prime} \mathrm{N} \\
140^{\circ} 32^{\prime} 51^{\prime \prime} \mathrm{E}\end{array}$ & Intertidal & $\begin{array}{l}\text { Rocks and macroin- } \\
\text { vertebrates }\end{array}$ & $\mathrm{HY}$ & $\begin{array}{l}1 \text { DNA sequenced } \\
\text { specimen }\end{array}$ \\
\hline- & May 6, 2012 & $\begin{array}{l}\text { Asamushi, Aomori, } \\
\text { Japan }\end{array}$ & $\begin{array}{l}40^{\circ} 54^{\prime} 11^{\prime \prime} \mathrm{N} \\
140^{\circ} 51^{\prime} 16^{\prime \prime} \mathrm{E}\end{array}$ & Intertidal & $\begin{array}{l}\text { Rocks and macroin- } \\
\text { vertebrates }\end{array}$ & HY & $\begin{array}{l}17 \text { DNA sequenced } \\
\text { specimens }\end{array}$ \\
\hline- & Sep. 11, 2011 & Fukaura, Aomori, Japan & $\begin{array}{l}40^{\circ} 45^{\prime} 59^{\prime \prime} \mathrm{N} \\
140^{\circ} 03^{\prime} 51^{\prime \prime} \mathrm{E}\end{array}$ & Intertidal & $\begin{array}{l}\text { Rocks and macroin- } \\
\text { vertebrates }\end{array}$ & HY & $\begin{array}{l}6 \text { DNA sequenced } \\
\text { specimens }\end{array}$ \\
\hline
\end{tabular}

in midlateral positions (Figs 19A, 20F, 21G), but very close to the laterodorsal areas. Sensory spots present in paradorsal, subdorsal and midlateral (posterior to glandular cell outlets) positions (Figs 19AB, 21G). Females with female papillae in ventromedial positions (Figs 19B, 20G, 21H); openings of papillae form short tubes with fine fringes around their margins (Fig. $21 \mathrm{H}$ ); intracuticular substructures each form a very short tubular or rhomboid structure (Fig. 20G). Glandular cell outlets type 1 as on preceding segment, but subdorsal ones are situated slightly closer to each other. Pachycycli, pectinate fringe of posterior margin and cuticular hairs as on preceding segment.

Segment 9 with acicular spines in lateroventral positions (Figs 19B, 21G), just reaching the posterior margin of the segment. Sensory spots present in paradorsal, subdorsal, laterodorsal, and ventrolateral positions (Figs 19A-B, 21G). Female papillae absent. Glandular cell outlets type 1 as on preceding segment, but with subdorsal ones situated even closer to each other, very close to paradorsal positions. Small, rounded nephridial sieve plates present in lateral accessory positions. Pachycycli, pectinate fringe of posterior margin and cuticular hairs as on preceding segment.

Segment 10 with long, slender midlateral tubes near posterior segment margin (Figs 19, 20H-J, 21I, K). Sensory spots present in subdorsal (but close to paradorsal) and ventrolateral positions (Figs 19, 21I-K); ventrolateral sensory spots are present in both sexes, but differ in appearance and longitudinal position: male sensory spots resemble other sensory spots, and are positioned about $1 / 4$ from the posterior segment margin, in the posterior limit of the hair covering (Figs 19D, 21J); female sensory spots are 
Table 15. Measurements from light microscopy for Echinoderes songae Sørensen \& Chang sp. nov. (in $\mu \mathrm{m})$, including number of measured specimens $(n)$ and standard deviation (SD).

\begin{tabular}{|c|c|c|c|c|}
\hline Character & $n$ & Range & Mean & SD \\
\hline TL & 11 & $266-302$ & 283 & 12.45 \\
\hline MSW-8 & 11 & $55-63$ & 60 & 2.58 \\
\hline MSW-8/TL & 11 & $19.9-22.9 \%$ & $21.0 \%$ & $0.86 \%$ \\
\hline SW-10 & 11 & $52-59$ & 56 & 2.51 \\
\hline SW-10/TL & 11 & $18.2-21.3 \%$ & $19.8 \%$ & $1.00 \%$ \\
\hline $\mathrm{S} 1$ & 11 & $26-30$ & 29 & 1.37 \\
\hline $\mathrm{S} 2$ & 11 & $25-30$ & 28 & 1.81 \\
\hline S3 & 11 & $26-31$ & 29 & 1.66 \\
\hline S4 & 11 & $30-36$ & 33 & 1.97 \\
\hline S5 & 11 & $33-39$ & 36 & 1.86 \\
\hline S6 & 11 & $34-41$ & 38 & 2.09 \\
\hline S7 & 11 & $36-44$ & 40 & 2.36 \\
\hline S8 & 11 & $37-44$ & 41 & 2.09 \\
\hline S9 & 11 & $38-43$ & 41 & 1.62 \\
\hline $\mathrm{S} 10$ & 11 & $37-45$ & 41 & 2.94 \\
\hline $\mathrm{S} 11$ & 11 & $32-34$ & 33 & 0.89 \\
\hline MD4 (ac) & 7 & $11-14$ & 12 & 1.11 \\
\hline MD5 (ac) & 6 & $11-16$ & 14 & 1.94 \\
\hline MD6 (ac) & 7 & $13-17$ & 15 & 1.38 \\
\hline MD7 (ac) & 9 & $14-18$ & 16 & 1.33 \\
\hline MD8 (ac) & 9 & $16-20$ & 18 & 1.36 \\
\hline LV2 (tu) & 4 & $15-23$ & 19 & 3.30 \\
\hline LV5 (tu) & 4 & $15-22$ & 18 & 3.30 \\
\hline LV6 (ac) & 11 & $14-18$ & 16 & 1.04 \\
\hline LV7 (ac) & 11 & $16-20$ & 18 & 1.19 \\
\hline LV8 (ac) & 11 & $17-23$ & 20 & 2.01 \\
\hline LV9 (ac) & 11 & $19-25$ & 21 & 1.86 \\
\hline ML10(tu) & 11 & $21-27$ & 25 & 1.76 \\
\hline LTS & 11 & $132-169$ & 151 & 8.30 \\
\hline LTS/TL & 11 & $47.0-59.0 \%$ & $53.5 \%$ & $3.86 \%$ \\
\hline LTAS & 6 & $34-44$ & 40 & 4.32 \\
\hline
\end{tabular}


Table 16. Summary of nature and location of sensory spots, glandular cell outlets, tubes and spines arranged by series in Echinoderes songae Sørensen \& Chang sp. nov.

\begin{tabular}{|c|c|c|c|c|c|c|c|c|c|c|}
\hline $\begin{array}{l}\text { Position } \\
\text { Segment }\end{array}$ & MD & PD & SD & LD & ML & SL & LA & LV & VL & VM \\
\hline 1 & gcol & & ss & ss & & ss & gco1 & & & ss \\
\hline 2 & gcol, ss & & & ss,ss & & & & tu & & gcol, ss \\
\hline 3 & gcol & & ss & ss & & ss & & & & gcol \\
\hline 4 & ac & & gcol, ss & & ss* & & & & & ss*, gcol \\
\hline 5 & $\mathrm{ac}$ & & gcol, ss & & ss & & & tu & & ss, gcol \\
\hline 6 & ac & ss & gcol, ss & & ss & & & $\mathrm{ac}$ & & ss, gcol \\
\hline 7 & ac & ss & gcol, ss & & ss & & & $\mathrm{ac}$ & fpa (P) & ss, gcol \\
\hline 8 & ac & ss & gcol, ss & & gco2, ss & & & $\mathrm{ac}$ & & gcol, fpa (P) \\
\hline 9 & & ss & gcol, ss & ss & & & si & $\mathrm{ac}$ & ss & gcol \\
\hline 10 & gcol, gco1 & & ss & & tu & & & & $\mathrm{ss}^{\mathrm{q} / \mathrm{d}^{2}}$ & gco1 \\
\hline 11 & gcol & & ss, ss & & $3 x p e\left(\delta^{1}\right)$ & & ltas (\%) & lts & ss & \\
\hline
\end{tabular}

more elongate, have less but longer micropapillae, and are located at the posterior segment margin (Figs 19B, 21K). Glandular cell outlets type 1 present as two longitudinally arranged middorsal ones and in ventromedial positions. The posterior segment margin of the tergal plate is straight, whereas margins of sternal plates are concave and extend midventrally into a point that almost reaches the posterior margin of the terminal segment (Fig. 21J-K); fringe tips of pectinate fringe are considerably shorter than those on preceding segments. Cuticular hairs as on preceding segments from middorsal to ventromedial positions, but the paraventral areas are only covered by very thin and delicate, non-bracteate, hair-like extensions. Pachycycli as on preceding segment.

Segment 11 with lateral terminal spines (Figs 19A-B, 20A, 21I). Males with three pairs of penile spines (Figs 19C-D, 20H, 21J); dorsal and ventral penile spines are thin, flexible tubes, whereas the median ones are slightly thicker, conical, and more rigid; females with short, thin lateral terminal accessory spines (Figs 19A-B, 20I-J, 21I-K). Two pairs of sensory spots present in subdorsal positions and one pair in ventrolateral positions (Figs 19,21I); one pair of subdorsal sensory spots medially on segment, other pair at posterior margin. A single, oval glandular cell outlets type 1 is present in middorsal position, anterior on segment. The dorsal side of the segment is densely covered with non-bracteate hair-like extensions; ventral side has hair-like extensions in paraventral areas, and as a dense covering along the posterior margins of the sternal plates. Tergal extensions are well-spaced, short and pointed (Figs 19, $20 \mathrm{H}-\mathrm{J}, 21 \mathrm{I}-\mathrm{K}$ ); sternal extensions short, with ventrolateral seta-like tuft of extended fringe tips (Figs 19, $21 \mathrm{~J}-\mathrm{K})$.

\section{Notes on distribution and habitat}

The species was found at numerous localities around the Korean Peninsula, at Jeju Island in the Korea Strait, at Dokdo/Takeshima Islands, Korean East Sea/Sea of Japan, and in northern Japan (around Hokkaido Island and the northernmost area of Honshu Island), suggesting that it has a pan-KoreanJapanese distribution. It is noteworthy that it apparently is highly opportunistic in its habitat choice, and often can be found associated with growth on macroinvertebrates and on macroalgae, as well as in mud, sand and mixed sediments. 
Echinoderes chandrasekharai Sørensen \& Chatterjee sp. nov. urn:1sid:zoobank.org:act:F8BC0D7A-18AD-455C-9A82-542A062C9BC2

Figs 22-24; Tables 17-18

Echinoderes cf. ehlersi - Higgins \& Rao 1979: 79-83, fig. 2 (specimens USNM-55391, USNM-55392, USNM-55394, USNM-55395, USNM-55397). — Adrianov \& Malakhov 1999: 18-19, fig. 5.29.

\section{Diagnosis}

Echinoderes with short middorsal spines on segments 4 to 8 , and lateroventral spines on segments 6 to 9; middorsal spines never reach the pectinate fringes of the posterior margins of their segments. Tubes present in lateroventral positions on segments 2 and 5 , and in laterodorsal positions on 10 . Minute glandular cell outlets type 2 in laterodorsal positions on segments 8 and 9 . Tergal extensions of segment 11 short, pointed and well-spaced; sternal extensions short, with ventrolateral seta-like tuft of extended fringe tips. Females with female papillae with crescentic intracuticular substructure in ventrolateral positions on segments 6 and 7 and in ventromedial positions on segment 8 .

\section{Etymology}

The species is dedicated to Dr G. Chandrasekhara Rao in recognition of his contributions to Indian kinorhynch studies, and for being the first to collect the new species (see Higgins \& Rao 1979).

\section{Material examined}

\section{Holotype}

INDIA - O; Andaman Islands, Havelock Island, East Point; 11 ${ }^{\circ} 54^{\prime} \mathrm{N}, 093^{\circ} 03^{\prime} \mathrm{E}$; < 1 m b.s.1.; 5 Apr. 1974; G.C. Rao leg.; intertidal black mud with macroalgae; USNM-55391. Specimen mounted for LM on Cobb slide in Hoyer's medium.

\section{Paratypes}

INDIA • 3 우, 1 J; same collection data as for holotype; USNM-55392, 55394, 55395 and 55397. Mounted as holotype.

The specimens were originally reported as Echinoderes cf. ehlersi (Higgins \& Rao 1979).

\section{Additional material}

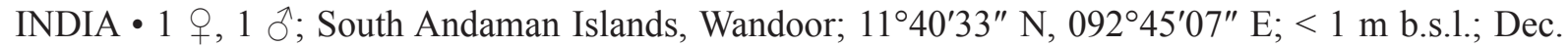
2005; T. Chatterjee leg.; intertidal sand and mud mixed with macroalgae; stored in the first author's personal reference collection - 1 क; South Andaman Islands, Burmanalla; $11^{\circ} 33^{\prime 2} 27^{\prime \prime}$ N, 092 $43^{\prime} 46^{\prime \prime}$ E; $<1 \mathrm{~m}$ b.s.l.; Dec. 2005; T. Chatterjee leg.; intertidal sand and mud mixed with macroalgae; stored in the first author's personal reference collection. Specimens mounted for SEM. See Table 1 for an overview.

\section{Description}

Adults with head, neck and eleven trunk segments (Figs 22A-B, 23A, 24A). Trunk with nearly equally broad sternal plates on segments 5 to 10 (Fig. 23A). Lateral terminal spines long and slender, from $45 \%$ to $69 \%$ of trunk length. Secondary pectinate fringe present near anterior segment margin of segments 2 to 10 , but it is usually covered by the preceding segment. For complete overview of measurements and dimensions, see Table 17. Distribution of cuticular structures, i.e., sensory spots, glandular cell outlets, spines and tubes, is summarized in Table 18.

The head consists of a retractable mouth cone and an introvert (Fig. 24B-C). Inner oral styles could not be examined. The external mouth cone armature consists of nine outer oral styles (Fig. 24B); bases of outer oral styles each with a V-shaped row of short fringe tips and a central bristle of much longer fringe 
Table 17. Measurements from light microscopy for Echinoderes chandrasekharai Sørensen \& Chatterjee sp. nov. (in $\mu \mathrm{m}$ ), including number of measured specimens $(n)$ and standard deviation (SD).

\begin{tabular}{|c|c|c|c|c|}
\hline Character & $n$ & Range & Mean & SD \\
\hline TL & 5 & $261-366$ & 296 & 42.90 \\
\hline MSW-8 & 5 & $56-74$ & 63 & 6.62 \\
\hline MSW-8/TL & 5 & $20.2-23.0 \%$ & $21.5 \%$ & $1.05 \%$ \\
\hline SW-10 & 5 & $54-74$ & 62 & $7.50 \%$ \\
\hline SW-10/TL & 5 & $20.0-21.9 \%$ & $20.9 \%$ & $0.84 \%$ \\
\hline S1 & 5 & $27-37$ & 32 & 3.58 \\
\hline S2 & 5 & $28-36$ & 31 & 3.13 \\
\hline S3 & 5 & $30-36$ & 32 & 2.55 \\
\hline S4 & 5 & $31-38$ & 34 & 2.59 \\
\hline S5 & 5 & $33-39$ & 36 & 2.77 \\
\hline S6 & 5 & $38-42$ & 40 & 1.79 \\
\hline S7 & 5 & $40-46$ & 43 & 2.24 \\
\hline S8 & 5 & $41-52$ & 46 & 4.06 \\
\hline S9 & 5 & $39-50$ & 45 & 3.96 \\
\hline S10 & 5 & $40-49$ & 44 & 3.51 \\
\hline S11 & 5 & $34-42$ & 37 & 3.11 \\
\hline MD4 (ac) & 4 & $9-10$ & 10 & 0.58 \\
\hline MD5 (ac) & 4 & $9-10$ & 10 & 0.58 \\
\hline MD6 (ac) & 4 & $9-11$ & 10 & 0.82 \\
\hline MD7 (ac) & 4 & $9-13$ & 11 & 1.71 \\
\hline MD8 (ac) & 4 & $11-15$ & 13 & 2.06 \\
\hline LV2 (tu) & 1 & 22 & - & - \\
\hline LV5 (tu) & 2 & $12-13$ & 20 & 0.71 \\
\hline LV6 (ac) & 5 & $12-13$ & 13 & 0.55 \\
\hline LV7 (ac) & 5 & $12-16$ & 14 & 1.41 \\
\hline LV8 (ac) & 5 & $14-17$ & 15 & 1.30 \\
\hline LV9 (ac) & 5 & $14-17$ & 15 & 1.30 \\
\hline LD10(tu) & 5 & $21-28$ & 25 & 2.77 \\
\hline LTS & 5 & $163-194$ & 177 & 11.59 \\
\hline LTS/TL & 5 & $44.5-68.8 \%$ & $61.1 \%$ & $9.91 \%$ \\
\hline LTAS & 4 & $45-55$ & 50 & 4.27 \\
\hline
\end{tabular}


tips. An additional fringe ring is present more posterior on mouth cone. The introvert sectors are defined by the ten primary spinoscalids in Ring 01 . Each primary spinoscalid consists of a basal sheath and a distal end piece with a blunt tip (Fig. 24C). The sheaths have two distinctively differentiated fringes: a most basal, transverse fringe, and a slightly more distal fringe where the fringe tips attach along a longitudinal line and alternatingly projects to the left and to the right (see inset Fig. 24C). End pieces are smooth and flexible. The arrangement of scalids in Rings 01 to 07 is very similar to the arrangement in E. dujardinii and a summary can be seen in Fig. 3. Rings 02 and 04 have 10 spinoscalids and Rings 03 and 05 have 20. All spinoscalids in these rings are well-developed, and consist of a basal sheath and a pointed end piece. The basal sheaths terminate into fine, fringed margins in spinoscalids of Rings 02 to 05 , and those of Rings 03 to 05 have in addition a basal median spike also. A ring of short fringes extend around the introvert in between spinoscalid Rings 04 and 05 . Ring 06 has only six spinoscalids, located in sectors $1,3,5,6,7$, and 9; ring 06 spinoscalids resemble those in preceding sectors, but without a distinct differentiation into sheath and end piece.

Ring 07 has 7 spinoscalids, located as pairs in sectors 3 and 9, unpaired but laterally displaced in sectors 5 and 7 (trichoscalids are taking up the space in the opposite side of each sector), and unpaired but centred in sector 1 (Fig. 23I).

Described sector-wise, sector 1 has spinoscalids arranged as two double diamonds anterior to a single spinoscalid in Ring 7. Sectors 2, 4, 8 and 10 all have spinoscalids arranged as a quincunx, located in between a medial anterior spinoscalid (Ring 02) and a trichoscalid plate. Sectors 3 and 9 have spinoscalids forming double diamonds anterior to a pair of spinoscalids in Ring 7. Sectors 5 and 7 also have spinoscalids forming double diamonds, but anterior to an unpaired, laterally spinoscalid. Sector 6 has spinoscalids arranged as two double diamonds (Fig. 3).

Trichoscalids with trichoscalid plates are present in sectors 2, 4, 5, 7, 8 and 10.

The neck has 16 placids, measuring $16 \mu \mathrm{m}$ in length. The midventral placid is broadest, measuring $13 \mu \mathrm{m}$ in width at its base, whereas all other are narrower, measuring $8 \mu \mathrm{m}$ in width at their bases. The trichoscalid plates in the dorsal sectors are composed of a distal part and a slightly broader proximal part, whereas the proximal parts of the ventral trichoscalid plates are much broader (Fig. 23I).

Segment 1 consists of a complete cuticular ring. Sensory spots are located near the anterior margin in subdorsal and laterodorsal positions, and slightly more posterior in sublateral and ventrolateral positions (Figs 22A-B, 24D-E); sensory spots are large, and rounded to oval, with numerous micropapillae, two pores, and often a cilium emerging from one of the pores. Glandular cell outlets type 1 present in middorsal and sublateral positions (Figs 22A-B, 23B-C, 24D). Cuticular hairs emerging through rounded perforation sites are covering the segment, except in a W-shaped ventral area on anterior segment half (Fig. 24E). The posterior segment margin is straight around the segment, terminating into a pectinate fringe with short, uniform fringe tips.

Segment 2 consists of a complete cuticular ring. Pachycyclus of the anterior segment margin is of medium thickness and not interrupted (Fig. 23B-C). Well-developed tubes present in lateroventral positions (Figs 22B, 23C, 24E). Sensory spots are located in middorsal (but slightly laterally displaced), laterodorsal (twin pair) and ventromedial positions (Figs 22A-B, 24D-E); sensory spots on this and all following segment oval, and same size or only slightly smaller than those on segment 1 . Glandular cell outlets type 1 present in middorsal and ventromedial positions (Figs 22A-B, 23B-C). The segment is densely covered with bracteate hairs; hair cover slightly thinner between ventromedial sensory spots. The posterior segment margin is nearly straight; pectinate fringe from middorsal to midlateral positions with short fringe tips, as on segment 1 ; fringe tips from midlateral to ventromedial positions conspicuously longer, and then very short again between ventromedial positions. 

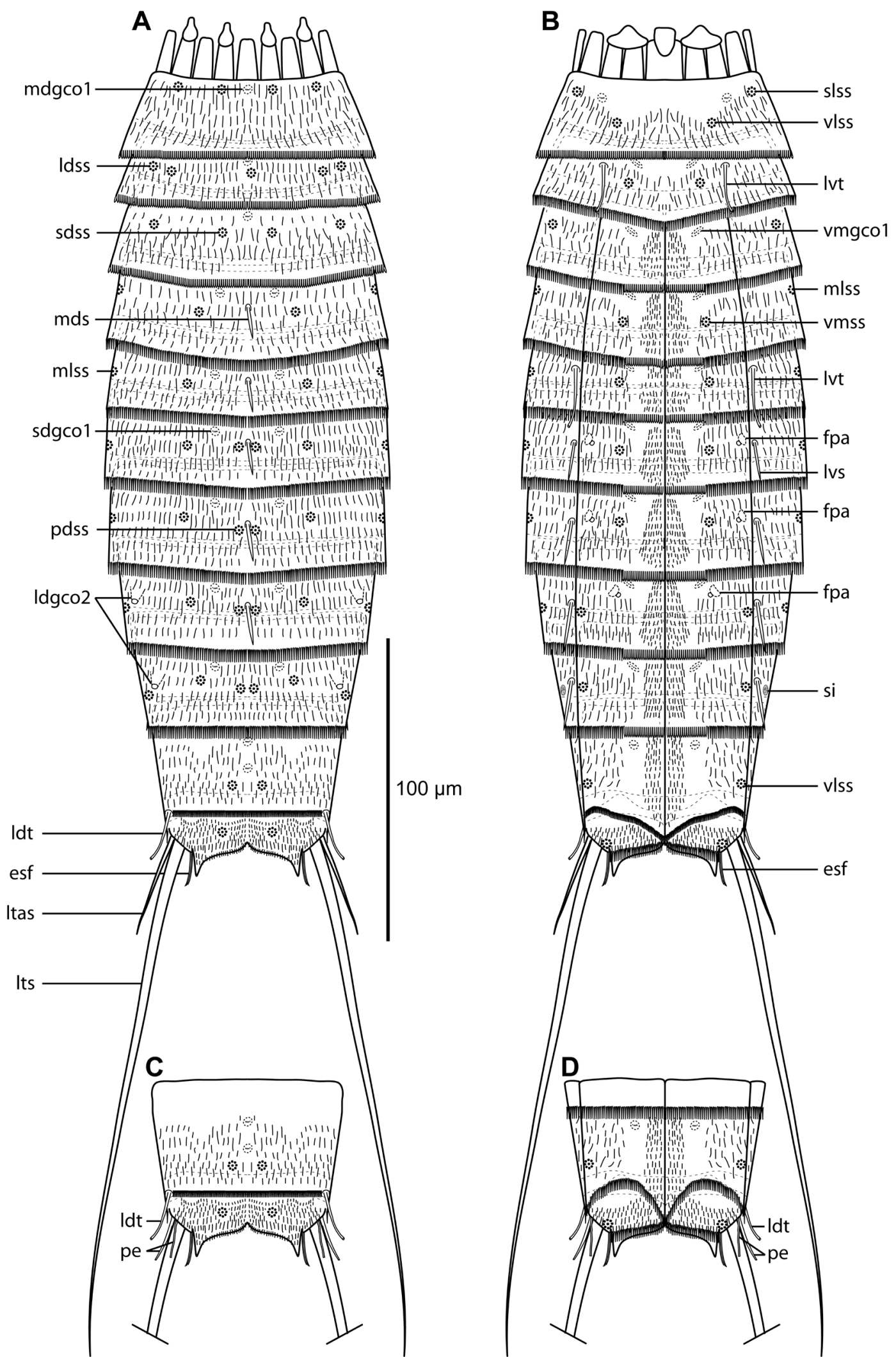

Fig. 22. Line art illustrations of Echinoderes chandrasekharai Sørensen \& Chatterjee sp. nov. A. Female, dorsal view. B. Female, ventral view. C. Segments 10 to 11 in male, dorsal view. D. Segments 10 to 11 in male, ventral view. 

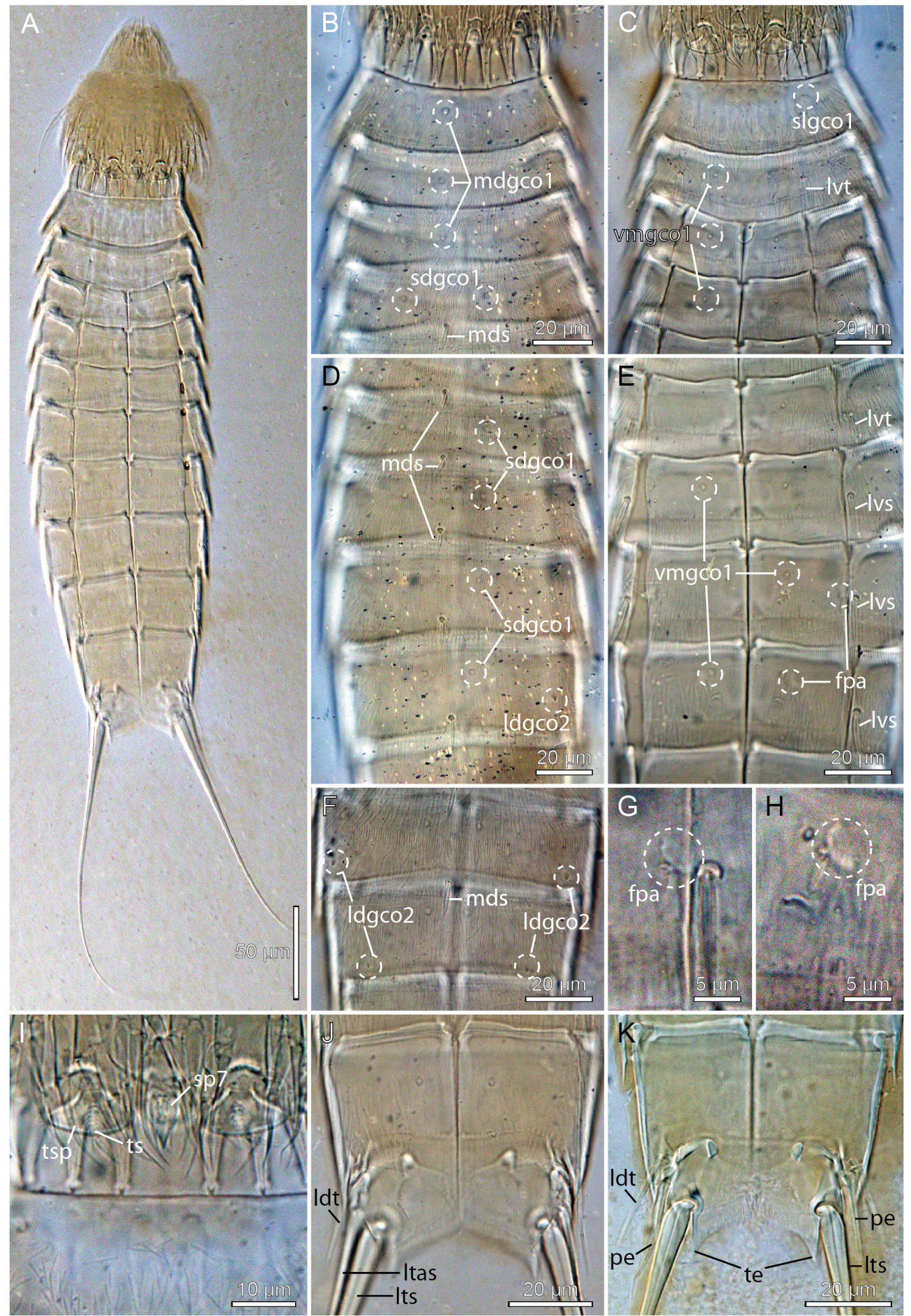

Fig. 23. Light micrographs showing overviews and details of Echinoderes chandrasekharai Sørensen \& Chatterjee sp. nov. A-E, G-J. Holotype, $q$ (USNM-55391). F. Paratype, $q$ (USNM-55394). K. Paratype, ô (USNM-55397). A. Ventral overview. B. Segments 1 to 4, dorsal view. C. Segments 1 to 4 , ventral view. D. Segments 4 to 8 , dorsal view. E. Segments 5 to 8 , ventral view, showing female sexual dimorphism. F. Segments 8 to 9 , dorsal view. G. Detail showing ventrolateral female papilla on segment 7. H. Detail showing ventromedial female papilla on segment 8. I. Detail showing ventral trichoscalids and trichoscalid plates. J. Segments 10 to 11, ventral view, showing female sexual dimorphism. K. Segments 10 to 11, ventral view, showing male sexual dimorphism. 

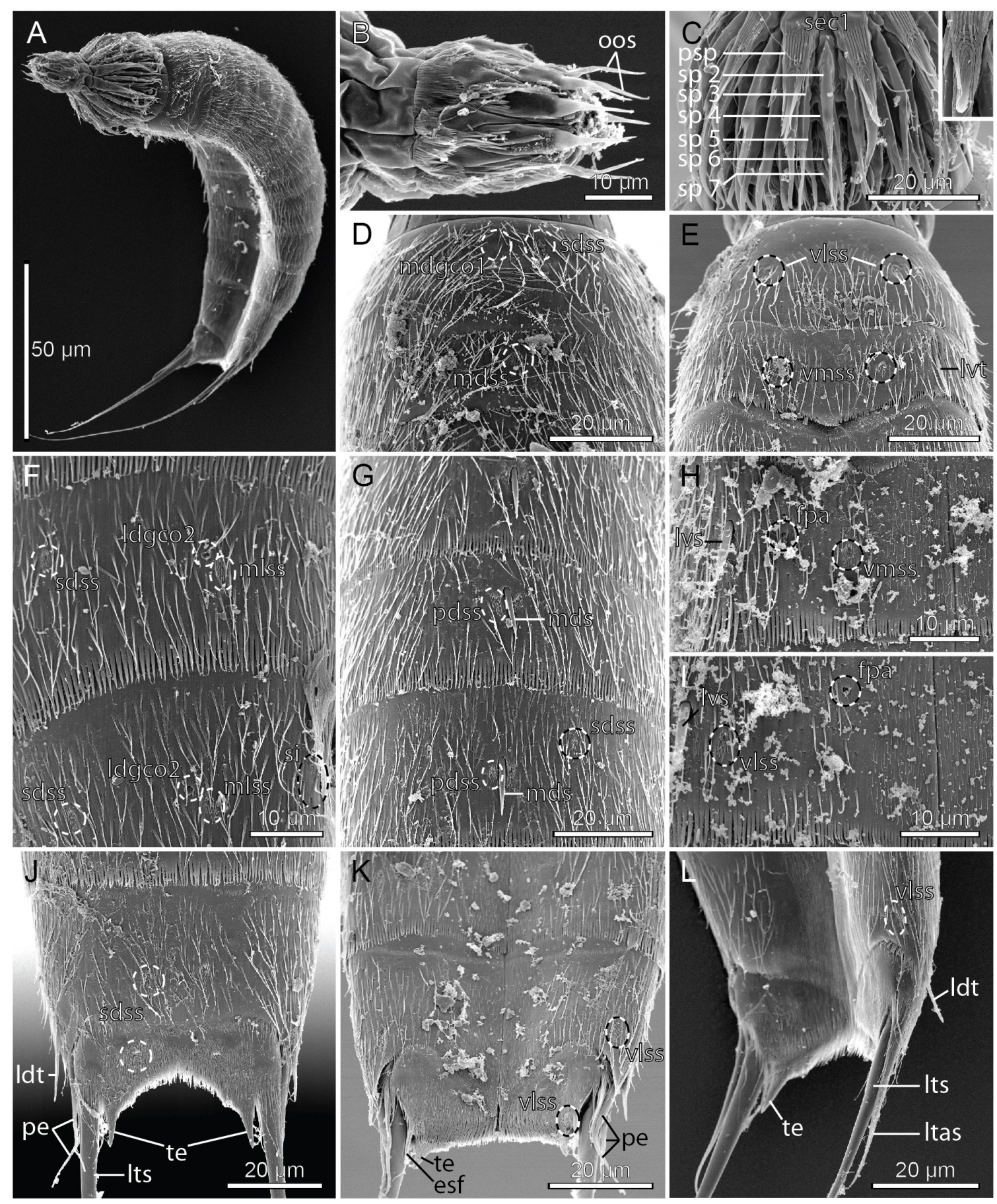

Fig. 24. Scanning electron micrographs showing overviews and details of Echinoderes chandrasekharai Sørensen \& Chatterjee sp. nov. A-C, H-I, K. ㅇ (MVS, personal reference collection). D-G, J, L. o (MVS, personal reference collection). A. Ventrolateral overview. B. Mouth cone, lateroventral view. C. Introvert sector 1 (ventral); inset shows detail of primary spinoscalid fringes, alternatingly attaching along a longitudinal line. D. Segments 1 to 2, dorsal view. E. Segments 1 to 2, ventral view. F. Segments 8 to 9 , lateral view. G. Segments 6 to 8, dorsal view. H. Right sternal plate of segment 7, showing female sexual dimorphism. I. Right sternal plate of segment 8, showing female sexual dimorphism. J. Segments 10 to 11 dorsal view, showing male sexual dimorphism. K. Segments 10 to 11 ventral view, showing male sexual dimorphism. L. Segments 10 to 11 ventrolateral view, showing female sexual dimorphism. 
Table 18. Summary of nature and location of sensory spots, glandular cell outlets, tubes and spines arranged by series in Echinoderes chandrasekharai Sørensen \& Chatterjee sp. nov.

\begin{tabular}{|c|c|c|c|c|c|c|c|c|c|c|}
\hline $\begin{array}{l}\text { Position } \\
\text { Segment }\end{array}$ & MD & PD & SD & LD & ML & SL & LA & LV & VL & VM \\
\hline 1 & gcol & & ss & ss & & ss, gcol & & & ss & \\
\hline 2 & gcol, ss & & & ss, ss & & & & tu & & ss, gcol \\
\hline 3 & gcol & & ss & ss & & ss & & & & gcol \\
\hline 4 & ac & & gco1, ss & & $\mathrm{ss}^{*}$ & & & & & ss, gco1 \\
\hline 5 & ac & & gco1, ss & & ss & & & tu & & ss, gcol \\
\hline 6 & $\mathrm{ac}$ & ss & gco 1, ss & & ss & & & $\mathrm{ac}$ & fpa ( $(+)$ & ss, gco1 \\
\hline 7 & ac & ss & gcol, ss & & ss & & & $\mathrm{ac}$ & fpa (P) & ss, gcol \\
\hline 8 & ac & ss & gco1, ss & gco2 & ss & & & $\mathrm{ac}$ & ss & gcol, fpa (†) \\
\hline 9 & & ss & gco1, ss & gco2 & ss & & si & $\mathrm{ac}$ & ss & gco1 \\
\hline 10 & gco1, gco1 & & ss & tu & & & & & ss & gco1 \\
\hline 11 & & & ss & & $3 x p e\left(0^{\pi}\right)$ & & 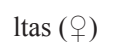 & lts & ss & \\
\hline
\end{tabular}

Segment 3, and remaining segments, consisting of one tergal and two sternal plates. Pachycyclus of the anterior segment margin of medium thickness, and interrupted only at tergosternal junctions (Fig. 23AB). Sensory spots present in subdorsal, laterodorsal and sublateral positions (Figs 22A-B). Glandular cell outlets type 1 present in middorsal and ventromedial positions (Figs 22A-B, 23B-C). Bracteate cuticular hairs are densely covering the segment from middorsal to ventromedial positions; shieldshaped paraventral areas densely covered by non-bracteate, hair-like extensions. Pectinate fringe of posterior margin hairs as on preceding segment.

Segment 4 with short acicular spine in middorsal position, not reaching the posterior margin of the segment (Figs 22A, 23B, D). Sensory spots present in subdorsal, midlateral and ventromedial positions (Fig. 23A-B); midlateral sensory spots considerably smaller than all other sensory spots on the animals, but they occur consistently in all examined specimens. Glandular cell outlets type 1 present in subdorsal and ventromedial positions (Figs 22A-B, 23C, 24B-D). Pectinate fringe of posterior segment margin with long fringe tips from middorsal to ventromedial positions conspicuously long, but very short between ventromedial positions. Pachycycli and cuticular hairs as on preceding segment.

Segment 5 with short acicular spine in middorsal position, not reaching the posterior margin of the segment, and well-developed tubes in lateroventral positions (Figs 22A-B, 23D-E, 24G). Sensory spots present in subdorsal, midlateral and ventromedial positions (Figs 22A-B). Glandular cell outlets type 1, pachycycli, pectinate fringe of posterior margin and cuticular hairs as on preceding segment.

Segment 6 with short acicular spines in middorsal and lateroventral positions (Figs 22A-B, 23D-E, $24 \mathrm{G}$ ); middorsal spine not reaching the posterior margin of the segment, and lateroventral spine just reaching the primary pectinate fringe. Sensory spots present in paradorsal, subdorsal, midlateral and ventromedial positions (Figs 22A-B, 24G). Females with female papillae resembling small glandular cell outlets type 2 in ventrolateral positions; the intracuticular structures of the papillae are crescentic with a small protuberance in the curved part of the structure (Fig. 22B). Glandular cell outlets type 1, pachycycli, pectinate fringe of posterior margin and cuticular hairs as on preceding segment. 
Segment 7 with short acicular spines in middorsal and lateroventral positions (Figs 22A-B, 23D-E, $24 \mathrm{G}-\mathrm{H}$ ); middorsal spine not reaching the posterior margin of the segment, and lateroventral spine just reaching the primary pectinate fringe. Females with female papillae resembling small glandular cell outlets type 2 (Fig. 24H), in ventrolateral positions (Figs 22B, 23E, 24H); the intracuticular structures of the papillae are crescentic with a small protuberance in the curved part of the structure (Fig. 23E). Sensory spots, glandular cell outlets type 1, pachycycli, pectinate fringe of posterior margin and cuticular hairs as on preceding segment.

Segment 8 with short acicular spines in middorsal and lateroventral positions (Figs 22A-B, 23D-F, 24G, I); middorsal spine not reaching the posterior margin of the segment, and lateroventral spine slightly overlapping the primary pectinate fringe. Minute glandular cell outlets type 2 present in laterodorsal positions (Figs 22A, 23D, F, 24F), but very close to the midlateral areas. Sensory spots present in paradorsal, subdorsal, midlateral (posterior to glandular cell outlets), ventrolateral positions (Figs 22AB, 23D-E, 24F-G, I). Females with female papillae showing same substructure as those on segment 7 , but with openings in ventromedial positions (Figs 22B, 23E, H, 24I). Glandular cell outlets type 1, pachycycli, pectinate fringe of posterior margin and cuticular hairs as on preceding segment.

Segment 9 with acicular spines in lateroventral positions, protruding slightly beyond primary pectinate fringe of posterior segment margin (Figs 22B). Sensory spots, glandular cell outlets type 1 and 2 as on preceding segment, but female papillae not present (Figs 22A-B, 24F). Small, rounded nephridial sieve plates present in lateral accessory positions (Fig. 24F). Pachycycli, pectinate fringe of posterior margin and cuticular hairs as on preceding segment.

Segment 10 with well-developed laterodorsal tubes near posterior segment margin (Figs 22, 23J-K, 24J, L). Sensory spots present in subdorsal (but close to paradorsal) and ventrolateral positions (Figs 22, $24 \mathrm{~J}-\mathrm{L}$ ). Glandular cell outlets type 1 present as two longitudinally arranged middorsal ones and in ventromedial positions. The posterior segment margin of the tergal plate is straight, whereas margins of sternal plates are concave (most deeply concave in males) and extend midventrally into a point that almost reaches the posterior margin of the terminal segment (Fig. $24 \mathrm{~K}-\mathrm{L}$ ); fringe tips of pectinate fringe are considerably shorter than those on preceding segments. Pachycycli and cuticular hairs as on preceding segment.

Segment 11 with lateral terminal spines (Figs 22, 23A, J-K, 24A, J-L). Males with three pairs of tubular penile spines (Figs 22C-D, 23K, 24J-K); dorsal and ventral penile spines are thin, flexible tubes, whereas the median ones are slightly thicker; females with short, thin lateral terminal accessory spines. Sensory spots present in subdorsal and ventrolateral positions (Figs 22, 23J-K, 24J-K). The dorsal and most of the ventral sides are densely covered with non-bracteate hair-like extensions, except in some areas near the anterior margin of the segment. Tergal extensions are well-spaced, short and pointed (Figs 22, 23K, 24J, L); sternal extensions short, with ventrolateral seta-like tuft of extended fringe tips (Figs 22, 24K).

\section{Putative new species not described}

\section{Echinoderes sp.}

Fig. 25; Table 19

Echinoderes cf. ehlersi - Higgins \& Rao 1979: 79-83 (specimens USNM-55393, USNM-55396, USNM-55398 to 55400). 
Table 19. Measurements from light microscopy for Echinoderes sp. from Havelock Island, Andaman Islands (in $\mu \mathrm{m}$ ), including number of measured specimens $(n)$ and standard deviation (SD).

\begin{tabular}{|c|c|c|c|c|}
\hline Character & $n$ & Range & Mean & SD \\
\hline $\mathrm{TL}$ & 5 & $280-321$ & 299 & 17.17 \\
\hline MSW-8 & 5 & $64-71$ & 66 & 2.83 \\
\hline MSW-8/TL & 5 & $21.0-23.2 \%$ & $22.1 \%$ & $0.83 \%$ \\
\hline SW-10 & 5 & $59-67$ & 62 & $3.13 \%$ \\
\hline SW-10/TL & 5 & $19.0-21.8 \%$ & $20.6 \%$ & $1.09 \%$ \\
\hline $\mathrm{S} 1$ & 5 & $29-32$ & 31 & 1.41 \\
\hline $\mathrm{S} 2$ & 5 & $29-31$ & 30 & 0.89 \\
\hline S3 & 5 & $30-32$ & 30 & 0.89 \\
\hline S4 & 5 & $32-37$ & 34 & 2.35 \\
\hline S5 & 5 & $33-38$ & 36 & 2.28 \\
\hline S6 & 5 & $34-39$ & 37 & 2.07 \\
\hline S7 & 5 & $39-41$ & 40 & 1.00 \\
\hline S8 & 5 & $41-48$ & 43 & 2.86 \\
\hline S9 & 5 & $43-48$ & 45 & 1.87 \\
\hline $\mathrm{S} 10$ & 5 & $41-46$ & 44 & 1.87 \\
\hline S11 & 5 & $37-42$ & 41 & 2.68 \\
\hline MD4 (ac) & 4 & $14-15$ & 15 & 0.58 \\
\hline MD5 (ac) & 4 & $15-19$ & 17 & 1.71 \\
\hline MD6 (ac) & 4 & $19-25$ & 22 & 2.65 \\
\hline MD7 (ac) & 4 & $23-30$ & 25 & 3.20 \\
\hline MD8 (ac) & 5 & $40-48$ & 44 & 3.77 \\
\hline LV2 (tu) & 3 & $23-25$ & 24 & 1.15 \\
\hline LV5 (tu) & 5 & $17-23$ & 20 & 2.19 \\
\hline LV6 (ac) & 5 & $15-18$ & 17 & 1.34 \\
\hline LV7 (ac) & 5 & $17-23$ & 19 & 2.51 \\
\hline LV8 (ac) & 5 & $22-26$ & 24 & 1.48 \\
\hline LV9 (ac) & 5 & $25-29$ & 26 & 1.67 \\
\hline LD10(tu) & 5 & $20-28$ & 23 & 3.13 \\
\hline LTS & 5 & $161-180$ & 173 & 7.56 \\
\hline LTS/TL & 5 & $53.7-63.9 \%$ & $58.0 \%$ & $5.00 \%$ \\
\hline LTAS & 1 & 48 & - & - \\
\hline
\end{tabular}




\section{Material examined}

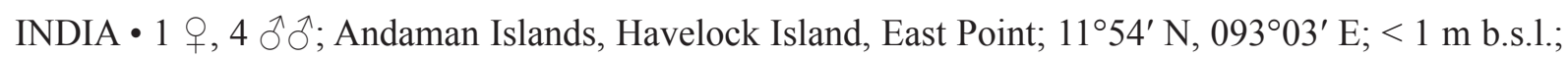
5 Apr. 1974; G.C. Rao leg.; intertidal black mud with macroalgae; USNM-55393, 55396, and 55398 to 55400. Specimens mounted for LM on Cobb slide in Hoyer's medium.

The specimens were originally reported as Echinoderes cf. ehlersi (Higgins \& Rao 1979). See Table 1 for an overview.

\section{Description}

The five specimens were collected together with another five specimens that all together were reported as Echinoderes cf. ehlersi by Higgins \& Rao (1979). However, our examinations suggested that the latter five specimens represent a new species. The five specimens, addressed in the following, differ from E. chandrasekharai Sørensen \& Chatterjee sp. nov. and as E. ehlersi in some significant points, but since the specimens' condition (e.g., the disability to observe sensory spots consistently) did not provide sufficient information for a complete description and specimens for SEM were not available, we will for now only provide a short description of the observed characters without providing a formal species description.

The examined specimens resemble species like E. kozloff, E. pacificus and E. sublicarum in general trunk appearance (Fig. 25A) and dimensions (see Table 19). The distribution of glandular cell outlets type 1 (Fig. 25B-G) is similar to the distribution in E. pacificus also (see Table 8), and so is the distribution of those sensory spots that could be observed. However, the presence or absence of sensory spots could not be confirmed in the following positions: sublateral segment 1 , middorsal segment 2 , midlateral segment 4 and segment 9 . The spine/tube pattern and the approximate dimensions are similar with those of $E$. kozloffi, i.e., the middorsal spine on segment 8 reaches to a point around the midline of segment 9 (Fig. 25D, F), but never onto segment 10. Glandular cell outlets type 2 are present in midlateral positions, but only on segment 8 (Fig. 25F). Female papillae are present in ventromedial positions on segments 7 (more lateral) and 8 (more medial) (Fig. 25E). The substructures of the papillae on segment 7 are crescentic with a small protuberance in the curved parts of the structures, whereas the substructures on segment 8 form narrow tubes (Fig. 25E). Tergal extensions of terminal segment and shape of lateral terminal spines resemble those in E. kozloff (Fig. 25G).

\section{Discussion}

\section{Identification of echinoderid species groups}

Among kinorhynch taxonomists it has traditionally been agreed that species of the diverse genus Echinoderes more or less follow the same overall anatomy, and that differences basically come down to presence, absence and position of spines, tubes and glandular cell outlets type 2 . However, the latest decade of research has shown that this conception is rather imprecise. Within Echinoderes we can observe a great variation in overall appearance, from the typical cigar-shaped specimens that are narrow in front and hind ends and often show the greatest width around segments 6 to 8, to species like E. cavernus Sørensen et al., 2000 or E. rociae Pardos et al., 2016 that have their widest segments on the anterior half of the trunk, or species such as Echinoderes higginsi Huys \& Coomans, 1989 and E. capitatus (Zelinka, 1928) with nearly constant segment width throughout the trunk (Zelinka 1928; Huys \& Coomans 1989; Sørensen et al. 2000; Pardos et al. 2016a; Yamasaki \& Dal Zotto 2019). We also see species, such as E. anniae Sørensen et al., 2018, with very thin pachycycli, that differ considerably from species with extraordinary strong pachycycli, as seen in E. skipperae Sørensen \& Landers 2014 (Sørensen \& Landers 2014; Sørensen et al. 2018). In addition to these differences that on one hand are obvious, but on the other hand difficult to quantify, we see much variation in distribution of glandular cell outlets, patterns in cuticular hair cover, shapes of tergal extensions, etc. 

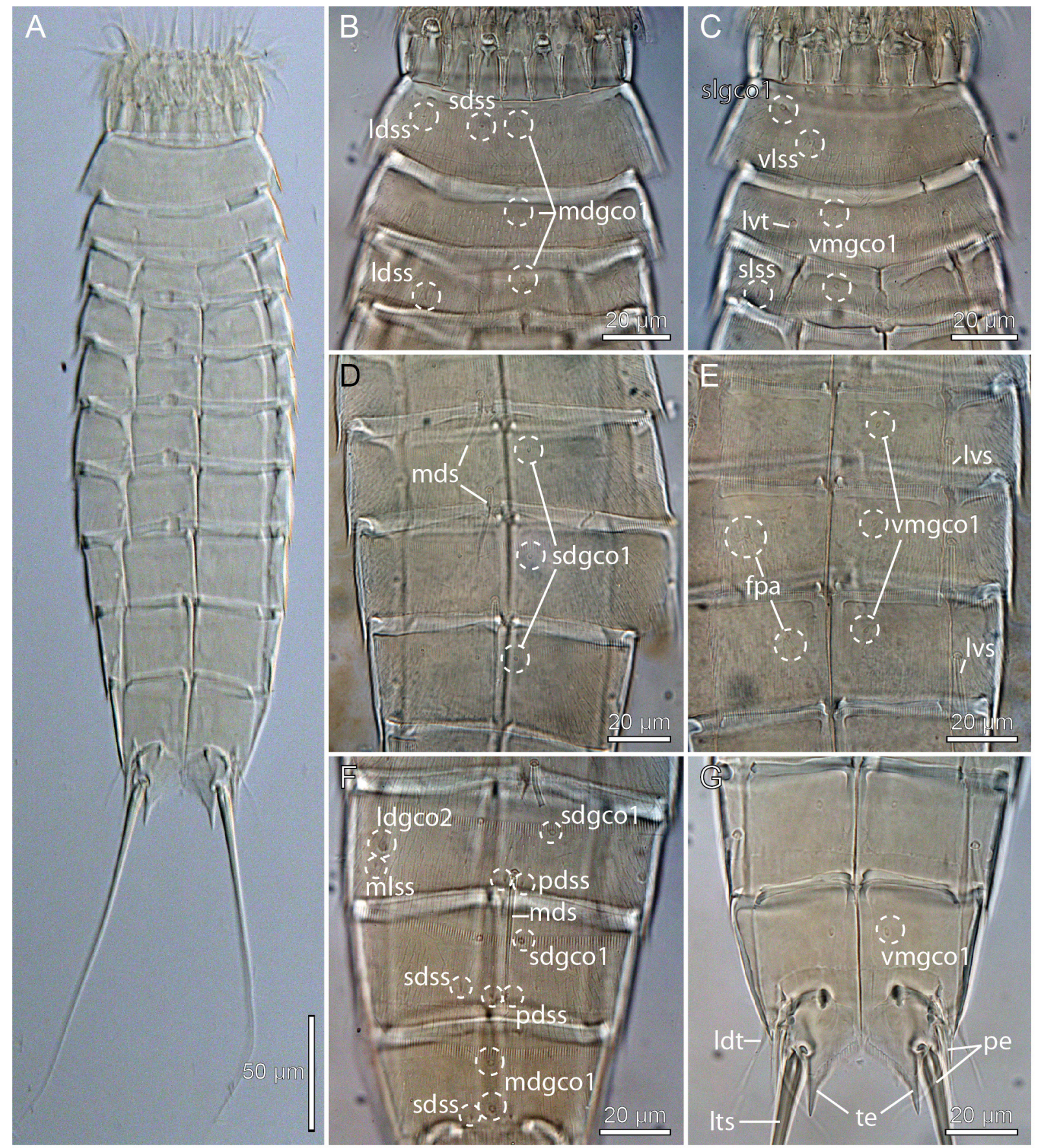

Fig. 25. Light micrographs showing overviews and details of Echinoderes sp. from Havelock Island, Andaman Islands. A-C, F-G. ô (USNM-55398). D-E. क् (USNM-55393). A. Ventral overview. B. Segments 1 to 3, dorsal view. C. Segments 1 to 3, ventral view. D. Segments 6 to 9, dorsal view. E. Segments 6 to 8, ventral view, showing female sexual dimorphism. F. Segments 8 to 10, dorsal view. G. Segments 9 to 11, ventral view, showing male sexual dimorphism. 
Nearly ten years ago, Neuhaus (2013) suggested that the diverse genus Echinoderes might be paraphyletic. Currently kinorhynch systematicians generally agree that the family Echinoderidae is in urgent need of revision, and that Echinoderes as well as the minor echinoderid genera might be either paraphyletic or polyphyletic. The issue was recently addressed in a meeting at the Fifth International Scalidophora Workshop (Di Domenico \& Sørensen 2019), and the participants agreed that 1) echinoderid phylogeny should be addressed with a combined morphological and phylogenomic approach, and that 2) taxon sampling should be based on a selection of representatives from putatively monophyletic species groups identified through morphology. A couple of such species groups have already been proposed. Sørensen (2014) proposed the Echinoderes coulli species group that accommodates mainly intertidal species with enlarged sieve plates and scarce spines, and a few years later Landers \& Sørensen (2018) and Sørensen et al. (2018) proposed the Echinoderes spinifurca species group, which accommodates species with acicular tergal extensions, identical spine/tube patterns and similarities in distribution of glandular cell outlets type 2. Results from the present study have enabled us to identify the co-occurrence of different character traits in a number of species, and based on these characters we would like to propose a third echinoderid species group.

\section{The Echinoderes dujardinii group - a new putative species group}

The present study focused on thirteen species of Echinoderes with very similar morphology, and the main objective was to explore whether it was possible to identify a putatively monophyletic species group among these thirteen species. During the studies it was revealed that E. lanceolatus should be considered a junior synonym of $E$. aureus, but that some paratypes of E. lanceolatus represented a different species that is described as Echinoderes songae Sørensen \& Chang sp. nov. Furthermore, the examination of specimens from the Andaman Islands, previously examined and addressed by Higgins \& Rao (1979), represented two different species, one of which is described in the present study as Echinoderes chandrasekharai Sørensen \& Chatterjee sp. nov. (the species synonymization and descriptions will be addressed in more detail below). Hence, this left us with a total of fifteen species to be considered.

Among these fifteen species, eleven appeared to share a certain combination of characters, and we propose that they together represent a putatively monophyletic group - the Echinoderes dujardinii group. The species group includes: E. dujardinii, E. ehlersi, E. gerardi, E. imperforatus, E. kozloffi, E. pacificus, E. sensibilis, E. sublicarum, E. songae Sørensen \& Chang sp. nov., E. chandrasekharai Sørensen \& Chatterjee sp. nov. and Echinoderes sp. from the Andaman Islands, and is characterized by the following character traits:

- Spine/tube pattern with: middorsal spines on segments 4 to 8 , lateroventral/ventrolateral tubes on segment 2, lateroventral tubes on segment 5 , lateroventral spines on segments 6 to 9 , laterodorsal or midlateral tubes on segment 10; lateral accessory tubes may or may not be present on segment 8 .

- Middorsal spine length: middorsal spines tend to be short, and those of segments 4 to 6 rarely extend beyond the posterior margin of their respective segments.

- Glandular cell outlets type 2: always present in laterodorsal or midlateral positions on segment 8; often, but not always, present in same positions on segment 9; never present on any other segments or in any other positions.

- Glandular cell outlets type 1: always present in middorsal positions on segments 1 to 3, and in subdorsal positions on segments 4 to 9 .

- Female papillae: female papillae always present on sternal plates of segments 7 and 8 , and occasionally also on segment 6 .

- Tergal extensions: tergal extensions well-spaced, triangular, gradually tapered cones. Acicular, asymmetrical, flexible, truncate or broadly rounded tips never occur.

- Sternal extensions: fringes of sternal extensions differentiated into seta-like tufts. 
The occurrence of significant characters for the E. dujardinii group is summarized in Table 20.

\section{Notes on diagnostic characters for the $E$. dujardinii species group}

With our currently rather limited understanding of echinoderid phylogeny, it is obviously impossible to polarize character traits and distinguish between synapomorphic and symplesiomorphic character conditions. Hence, it is important to stress that the characters proposed for the E. dujardinii group for now should be understood as diagnostic, rather than autapomorphic. The difficulties pointing out undisputable autapomorphies obviously weakens the support for the E. dujardinii group as a natural entity, but we believe that the presence of several, co-occurring characters still speaks in favour of monophyly. When exploring the distribution of morphological character traits across all echinoderid taxa, it quickly becomes obvious that many characters, such as spines, tubes, sensory spots and glandular cell outlets, are extremely homoplastic. Hence, it will most likely not be possible to identify clades based on the presence of single characters. Therefore, we choose to promote a different approach, which is the co-occurrence of characters. Even though a single spine or a pair of glandular cell outlets hardly can be considered as unambiguous support for a clade, we find it plausible that such characters in combination can be phylogenetically significant if they always show up together. Hence, identifying these character combinations can help us distinguishing between homoplasies and synapomorphies.

Spine/tube patterns: the observed spine/tube pattern among the E. dujardinii group species is definitely not autapomorphic, since it is among the most common patterns within Echinoderidae. It is nevertheless important, since no species with a different spine/tube pattern shows the character combination that characterizes the E. dujardinii group species. This suggests, that this otherwise common pattern has been conserved within the group. The only observed deviation from the shared spine/tube pattern is the presence of lateral accessory tubes on segment 8 in E. dujardinii and E. gerardi. This stresses that the presence of such tubes probably evolved several times among echinoderids. Another interesting trait related to the spines is the tendency towards having really short middorsal spines - especially on the more anterior segments. Segment 8 always has the longest middorsal spine, but still, among the eleven species of the E. dujardinii group, at least six (probably seven if E. ehlersi is included) have a middorsal spine on segment 8 not even extending beyond the posterior margin of the segment: E. dujardinii, E. gerardi, E. imperforatus, E. sensibilis, E. songae Sørensen \& Chang sp. nov. and E. chandrasekharai Sørensen \& Chatterjee sp. nov. While exploring this, we noticed an interesting character correlation: apparently, the four species with the middorsal spine of segment 8 extending well (i.e., $>40 \%$ ) beyond the posterior segment margin would also be those that were missing paired glandular cell outlets type 2 on segment 9: E. kozloffi, E. pacificus, E. sublicarum, and Echinoderes sp. Andaman Islands (Table 20). This nearly lead us to propose two separate species groups, the E. dujardinii group and the E. pacificus group, where the latter would be characterized by longer middorsal spines and the presence of glandular cell outlets type 2 on segment 8 only. However, the consistency was distorted by E. songae Sørensen \& Chang sp. nov. that shows a short middorsal spine on segment 8 and the absence of glandular cell outlets type 2 on segment 9 . Hence, we find it more likely that the four taxa with longer middorsal spines are an ingroup of the E. dujardinii group, and either represent a monophylum within the group, or alternatively represent its four most basal taxa.

Glandular cell outlets type 2: the presence and positions of glandular cell outlets type 2 has become an important character in modern echinoderid taxonomy (see e.g., Neuhaus \& Blasche 2006; Sørensen et al. 2012, 2018; Pardos et al. 2016a, 2016b; Cepeda et al. 2019a; Yamasaki et al. 2019). Among species of the E. dujardinii group we consistently find minute glandular cell outlets type 2 in laterodorsal or midlateral positions of segment 8, and in those with short middorsal spines (except for E. songae Sørensen \& Chang sp. nov.) we also find it in the same positions on segment 9 (Table 20). In combination with the other characters, we consider the presence of glandular cell outlets type 2 on segments 8 (and possibly 9) as diagnostic and potentially synapomorphic for species of the E. dujardinii group. Among 
Table 20. Comparative table with shared and differential characters for species of the Echinoderes dujardinii group and similar species (four lower ones) outside the group. Grey cell = absent; black cell = present; white cell $=$ character unknown .

1: Midventral intracuticular fissure in segment 2

2: Tips of middorsal spines on segments 5 to 7 surpass beyond posterior margins of their respective segments

3: Middorsal spine on segment 8 surpasses well (distal 40-50\%) beyond posterior segment margin, reaching midline of segment 9

4: Middorsal spine on segment 8 surpasses well (distal 60-80\%) beyond posterior segment margin, reaching midline of segment 10

5: Lateral accessory tube on segment 8

6: Midlateral tubes on segment 10 short, curved, and truncate

7: Proximal $1 / 3$ of lateral terminal spines swollen

8: Single glandular cell outlets type 1 in middorsal positions on segments 1 to 3 , and paired in subdorsal positions on segments 4 to 9

9: Glandular cell outlets type 2 in subdorsal positions on segment 2

10: Glandular cell outlets type 2 in laterodorsal or midlateral positions on segment 8

11: Glandular cell outlets type 2 in laterodorsal or midlateral positions on segment 9

12: Ventrolateral female papillae on segment 6; tubular substructure

13: Ventrolateral female papillae on segment 6 ; crescentic substructure

14: Ventromedial female papillae on segment 6; crescentic substructure

15: Ventrolateral female papillae on segment 7; tubular substructure

16: Ventrolateral female papillae on segment 7; crescentic substructure

17: Ventromedial female papillae on segment 7; tubular substructure

18: Ventromedial female papillae on segment 7; crescentic substructure

19: Ventromedial female papillae on segment 8; tubular substructure

20: Ventromedial female papillae on segment 8; crescentic substructure

21: Sternal extensions of segment 11 with extended seta-like fringe tips

22: Tergal extensions of segment 11 with extended seta-like fringe tips

23: Cuticular hairs without distinct perforation sites

\begin{tabular}{|c|c|c|c|c|c|c|c|c|c|c|c|c|c|c|c|c|c|c|c|c|c|c|c|}
\hline Species / characters & 1 & 2 & 3 & 4 & 5 & 6 & 7 & 8 & 9 & 10 & 11 & 12 & 13 & 14 & 15 & 16 & 17 & 18 & 19 & 20 & 21 & 22 & 23 \\
\hline E. dujardinii & & & & & & & & & & & & & & & & & & & & & & & \\
\hline E. ehlersi & & & & & & & & & & & & & & & & & & & & & & & \\
\hline E. gerardi & & & & & & & & & & & & & & & & & & & & & & & \\
\hline E. imperforatus & & & & & & & & & & & & & & & & & & & & & & & \\
\hline E. sensibilis & & & & & & & & & & & & & & & & & & & & & & & \\
\hline E. songae sp. nov. & & & & & & & & & & & & & & & & & & & & & & & \\
\hline $\begin{array}{l}\text { E. chandrasekharai } \\
\text { sp. nov. }\end{array}$ & & & & & & & & & & & & & & & & & & & & & & & \\
\hline E. kozloffi & & & & & & & & & & & & & & & & & & & & & & & \\
\hline E. pacificus & & & & & & & & & & & & & & & & & & & & & & & \\
\hline E. sublicarum & & & & & & & & & & & & & & & & & & & & & & & \\
\hline E. sp. Andaman Isl. & & & & & & & & & & & & & & & & & & & & & & & \\
\hline E. aureus & & & & & & & & & & & & & & & & & & & & & & & \\
\hline E. gizoensis & & & & & & & & & & & & & & & & & & & & & & & \\
\hline E. pilosus & & & & & & & & & & & & & & & & & & & & & & & \\
\hline E. worthingi & & & & & & & & & & & & & & & & & & & & & & & \\
\hline
\end{tabular}


the examined species, the exact positions of the outlets appeared to differ between being in laterodorsal or midlateral positions, but we do not believe that this questions the homology of the outlets across the different species. Instead, it just stresses that exact positions of cuticular structures may be a bit obscured on the narrowing posterior trunk segments. During this study, E. pilosus was considered as a potential ingroup of the E. dujardinii group, and its possession of glandular cell outlets type 2 on segments 8 and 9 could support this. However, E. pilosus deviates from the pattern by also having such outlets in subdorsal positions on segment 2 . These outlets on segment 2 could be considered as autapomorphic for the species, but it also differs from $E$. dujardinii group species in other respects (see more detailed notes below), which all together stressed that type 2 outlets are restricted to segments 8 and 9 in the E. dujardinii group. This confirms that it is not the single character itself, but their combined presence along the trunk that provides the phylogenetic signal. In fact, having type 2 outlets in laterodorsal or midlateral positions on segments 8 and/or 9 is found in no less than 21 additional echinoderid species besides those examined in the present study. However, all of these also have type 2 outlets on other segments, a considerably different spine/tube pattern, or differ in another way. The species that shows the best character correlation with species of the E. dujardinii group is actually Echinoderes sylviae Landers \& Sørensen, 2018. Its spine/tube pattern and distribution of glandular cell outlets type 2 corresponds with those of E. dujardinii group species, and it even has female papillae on the sternal plates of segments 7 and 8. However, as pointed out by Landers \& Sørensen (2018), E. sylviae very clearly belongs to another echinoderid species group, the E. spinifurca group, which is especially supported by the acicular shape of its tergal extensions. Furthermore, E. sylviae differs from E. dujardinii group species by having longer, thinner and more flexible middorsal spines, and by having a different pattern of dorsal glandular cell outlets type 1 (Landers \& Sørensen 2018). Hence, also this example stresses the need for analysing the combination of characters, and not only the occurrence of a single or a few characters.

Glandular cell outlets type 1: the distribution of glandular cell outlets type 1 is rarely used in echinoderid taxonomy, but during the study we noticed that all species of the E. dujardinii group appear to have the same distribution of these gland outlets on segments 1 to 10, i.e., glandular cell outlets type 1 in middorsal positions on segments $1,2,3,10$, and in subdorsal positions on segments 4 to 9 ; and in the ventral series, laterally displaced (sublateral to ventromedial) outlets on segment 1 and ventromedial ones on segments 2 to 10 . We will not comment any further on the ventral pattern as it is extremely common, and pretty much universal for all echinoderid species. The pattern of the dorsal series deserves some attention though, as its taxonomic significance became obvious during the present study. While trying to distinguish LM specimens of E. aureus and E. sensibilis from the same or nearby localities, we realized that the fastest and easiest way to distinguish the species was by examining the dorsal pattern of their type 1 outlets. The different pattern in E. aureus, i.e., the presence of paradorsal outlets on segments 4, 6, 8, 9 and middorsal outlets on segments 5 and 7, rather than subdorsal outlets on these segments, made it easy to identify the species. It furthermore pointed out that this species should not be considered part of the E. dujardinii group. Differences in distribution of dorsal type 1 outlets were also noted in E. gizoensis and E. pilosus. Among the four non-E. dujardinii group species examined for the present study, only $E$. worthingi showed the same pattern of dorsal type 1 outlets on segments $1-9$ as the $E$. dujardinii group species. Additional notes about patterns of glandular cells outlets type 1 among echinoderids are provided below, under 'Notes on morphological observations'.

Female papillae: all species of the E. dujardinii group have female papillae on the sternal plates of segments 7 and 8 , and occasionally also on segment 6 as well (Table 20). The exact positions of the papillae may differ from ventrolateral to ventromedial, and the intracuticular substructure may vary between tubular to rhomboid shapes, or the conspicuous crescentic shape with a small nipple-like tube on the curved part of the structure. Within the E. dujardinii group we did not see any clear patterns in the positions and substructure of the papillae, but it was noted that the female papillae always would be 
present, and that their position and substructure could be helpful in species identification. Additional, more general notes about female papillae are provided below, under 'Notes on morphological observations'.

Tergal extensions: the tergal extensions on the terminal segment come with the same shape in all species of the E. dujardinii group, i.e., very well-spaced, triangular extensions with gradually pointed tips (Figs 2G, 4K, 6G, 7I, 13I, 14L, 19H, 22E). Unlike many other echinoderid characters, such as spine/tube lengths and positions, it is difficult to provide an exact, unambiguous definition for the tergal extensions of the E. dujardinii group. Identification of the character has to be based on visual recognition, which may require a bit of experience. Still, we believe that this is an important character. The morphology of the tergal extensions is first of all very constant among species of the group, and secondly, it is relatively easy to distinguish their shape from other echinoderid tergal extensions. This particular shape of tergal extensions may not be unique for the species of the E. dujardinii group, and for instance a species like $E$. aureus has tergal extensions that are very similar (Fig. 1J). But still, the shape of the tergal extensions is very useful to exclude other species from the group. Among the four non-E. dujardinii group species examined for the present study, only E. aureus has tergal extensions resembling those that are typical for species within the group. Tergal extensions of E. pilosus are very short, and not very well-defined (Fig. 10J), whereas those of E. worthingi (Figs 16J, 17G) and E. gizoensis (Thormar \& Sørensen 2010) terminate into flexible, seta-like tips.

Sternal extensions: all species of the $E$. dujardinii group share the presence of sternal extensions with a part of their pectinate fringes differentiated into seta-like tufts (Figs 5H, 14J, 15K, 24K). Again, this character is not unique for the E. dujardinii group, but can for instance also be found in E. pilosus (Fig. 10K). Besides the species examined in the present study, similar structures have been reported from other echinoderids, such as Echinoderes adrianovi Herranz et al., 2014, E. anniae, E. cantabricus Pardos et al., 1998, and E. hakaiensis Herranz et al., 2018 (Pardos et al. 1998; Herranz et al. 2014, 2018; Sørensen et al. 2018). Hence, the presence of this character should be considered as diagnostic for the E. dujardinii group, but not necessarily as autapomorphic.

\section{Differential notes on species of the $E$. dujardinii species group}

\section{Echinoderes dujardinii and $\boldsymbol{E}$. gerardi - synonymous or separate species?}

Echinoderes dujardinii was the first kinorhynch species to be described (Claparède 1863), and the description obviously does not follow present day standards, nor are any type specimens available today. However, Higgins (1977a) provided a redescription of the species, based on specimens from the type locality. Only one year later, Higgins (1978) described a new and very similar species from Tunisia and named it Echinoderes gerardi. According to Higgins (1978) the two species could be distinguished by 1) differences in length of middorsal and lateroventral spines (in E. dujardinii mds: 15-20 $\mu \mathrm{m}$ and lvs: 18-25 $\mu \mathrm{m}$ vs in E. gerardi mds 9-10 $\mu \mathrm{m}$ and lvs 15-19 $\mu \mathrm{m}), 2$ ) the shape of the spines, 3) the shape of the trichoscalid plates, 4) the dorsal hair patterns, and 5) the ventromedial sensory spots on segment 2 , being present in E. gerardi but absent in E. dujardinii.

The present study prompted a re-examination of the two species, with special emphasis on the diagnostic characters suggested by Higgins (1978). We can, however, only confirm differences regarding spine shape and dimensions, and these differences seem to be most prominent in the middorsal series. Hair patterns appear to be very similar in the two species, and so does the shape of the trichoscalid plates. Regarding differences in sensory spot distribution, Higgins (1977a, 1978) seems to confuse sensory spots and glandular cell outlets type 1 from time to time, but a comparison based on data from the present study shows that both sensory spot as well as glandular cell outlet patterns are identical for the two species. 
During the present study, the only observed difference in distribution of cuticular structures regarded the ventrolateral sensory spots on segment 10, that are present in both sexes in E. gerardi but is restricted to males in E. dujardinii (this sexual dimorphism appears to be the most common among species of the E. dujardinii group). Hence, beside this sexual dimorphism, we are left with measurements as the only way to distinguish the two species. Total trunk length is not useful, because even though some specimens of E. dujardinii tend to be larger than E. gerardi, the trunk length of the latter is still within the lower range of $E$. dujardinii. Dorsal and lateral spines are actually shorter in E. gerardi, and even though measurements of specimens from the Iberian Peninsula bring length ranges within the two species closer to each other, the ranges show a minimal overlap. Length ranges for the middorsal spines series overlap with $1-2 \mu \mathrm{m}$, but practically it is still relatively easy to tell from the spine length whether it is E. dujardinii or E. gerardi (compare measurements in Tables 3 and 6). The shape of the middorsal spine can be an additional indicator here. Even though the character might sound rather subtle, it is actually fairly easy, at high magnification obviously, to tell if the spine is acicular as in E. dujardinii (Figs 2D, 4F) or lanceolate as in E. gerardi (Fig. 5B, D). We do not see the same difference in spine shape in the lateroventral spine series, but the nearly discrete size ranges in spine lengths are present here as well, with overlaps of only $1-2 \mu \mathrm{m}$ on segments 6 to 8 , and $5 \mu \mathrm{m}$ on segment 9 .

Hence, the two species can be distinguished by spine lengths and shapes. This leaves us with the question whether we would accept such characters as species diagnostic. The short answer is that no one knows, and that it would require a genetic comparison to provide an objective answer. However, ever since E. gerardi was described, it has been accepted as a valid species, pretty much based solely on these meristic diagnostics, and we see no reason to change this. If a population with spine ranges that clearly overlap both species shows up, this would obviously change the picture, and E. gerardi would have to be accepted as a junior synonym of $E$. dujardinii, but until this happens our recommendation is to see them as two distinct species.

\section{Distributional ranges of Echinoderes dujardinii and $E$. gerardi}

The summary provided by Higgins (1977a) suggests that $E$. dujardinii has a distributional range stretching from Bergen at the Norwegian west coast to the Canary Islands, and throughout the Mediterranean Sea and into the Black Sea. However, these records should be considered with great caution, since most of them predate 1920 and belong to a time when any European Echinoderes could be reported as E. dujardinii. Furthermore, as pointed out in the present study, the differences between E. dujardinii and $E$. gerardi are so subtle that both species need to be taken into account. This especially makes all Mediterranean reports predating the description of E. gerardi questionable. Hence, the only reliable reports of E. dujardinii predating Higgins (1977) are those from Saint Vaast La-Hougue in Normandy (type locality), and Saint-Malo and Roscoff in Brittany, France (Dujardin 1851; Claparède 1863; Higgins 1977a).

More recent reports of E. dujardinii include a single report from the Sinop Bay, southern Black Sea (Ürkmez et al. 2016), one from the Adriatic Sea near Venice (Mari \& Morselli 1987) and several from the Iberian Peninsula (Sánchez-Tocino et al. 2011; Sánchez et al. 2012), but also in these cases the correct species identity has to be questioned. Specimens of the Black Sea population reported by Ürkmez et al. (2016) are well-documented. The spine and tube distribution in the documented specimens, including the presence of lateroventral glandular cell outlets type 2 on segments 8 and 9 (not mentioned in the text, but shown in Ürkmez et al. 2016: fig. 3c), fit the morphology of both E. dujardinii and E. gerardi. The provided photos also allow the reader to check the spine lengths in both the middorsal and laterodorsal series. All spines fall within the ranges of $E$. gerardi and outside the ranges of $E$. dujardinii, suggesting that the Black Sea species reported by Ürkmez et al. (2016) is E. gerardi. The record of $E$. dujardinii from the Venice Lagoon reported by Mari \& Morselli (1987) is difficult to validate because the specimens are not documented. However, we believe that this species could just as well be E. gerardi, and this view 
is shared with Dal Zotto \& Todaro (2016). Sánchez-Tocino et al. (2011) reported E. dujardinii from Almuñécar at the Spanish Mediterranean south coast, but not that far away from the Gibraltar Strait. The documentation of their specimens is quite thorough in terms of photos, measurements and written comments. Unfortunately, they do not provide LM photos showing middorsal or lateroventral spines, which could have validated their identification. They only provide a few measurements of spine lengths (from 1 to 3 for each relevant spine), but all these measurements (except for one questionable, unusually long lateroventral spine on segment 8) fall within the ranges of $E$. gerardi and outside the ranges of E. dujardinii, suggesting that these specimens are also E. gerardi. In a comprehensive contribution about kinorhynchs from the Iberian Peninsula, Sánchez et al. (2012) report E. dujardinii from several localities including Galicia (Atlantic west coast), Algeciras (Gibraltar Strait), Almuñécar (Mediterranean south coast), Murcia and Alicante (Mediterranean southeast coast). Thanks to Dr F. Pardos, we could loan material from these collecting campaigns to validate the identity of the reported species. It turned out that all Mediterranean specimens as well as the Atlantic ones from Cadiz (about $100 \mathrm{~km} \mathrm{NW}$ of the Gibraltar Strait) and Algeciras (basically at the Gibraltar Strait), were E. gerardi. The remaining Atlantic ones collected west and north of Cadiz were E. dujardinii (see Table 1).

Echinoderes gerardi was originally described from the Gulf of Tunis in Tunisia, where they were washed out of sponges (Higgins 1978). Since its discovery, the species has very rarely been reported again, and one could be left with the impression that potential conspecifics sometimes were reported as $E$. dujardinii, whereas $E$. gerardi was not considered as a likely alternative. However, we have two recent reports of the species, together with the species reported in the present contribution. Sönmez et al. 2016 reported E. gerardi from Izmir at the Aegean coast of Turkey. They document the middorsal spines, and they are well within the range of the short-spined $E$. gerardi. The provided LM image even shows the characteristic lanceolate shape of the middorsal spines (see Sönmez et al. 2016: fig. 1b), hence, the proposed identity of the species can be validated. In the same year, Dal Zotto \& Todaro (2016) published their review on Italian kinorhynchs, and reported E. gerardi from Sicily. In their contribution, Dal Zotto \& Todaro (2016) are obviously aware of the close resemblance between E. gerardi and E. dujardinii, and we consider the provided identity to be correct.

Hence, based on the currently available information, it appears that E. dujardinii is an Atlantic, West European species with confirmed presences in France, Atlantic Spain, and Portugal, whereas E. gerardi is a mostly Mediterranean species. Based on the currently available information, the border between the two species appears to go somewhere at the Atlantic south coast of Spain, between Huelva and Cadiz.

\section{Differential notes on $E$. ehlersi}

Zelinka (1913) described the species Echinoderes ehlersi from Zanzibar in Tanzania, on the African east coast. The species was never found again, but 61 years later Dr G.C. Rao collected somewhat similar specimens (Figs 21-24) from Havelock Island in the Andaman Islands, and Higgins \& Rao (1979) suggested that these specimens could be conspecific with E. ehlersi-an identification that was considered questionable by Chatterjee (2019). With today's improved understanding of Echinoderes taxonomy and biodiversity, and with the new information revealed in the present study, we would suggest that 1) the description of E. ehlersi is so simplistic that it cannot be used to unambiguously recognize a species, and 2) the specimens from Havelock Island represent two different species, of which one is described as E. chandrasekharai Sørensen \& Chatterjee sp. nov. (see notes on diagnostic characters below).

According to Zelinka $(1913,1928)$, E. ehlersi is a species with middorsal spines on segments 4 to 8 , lateroventral tubes on segments 2 and 5, lateroventral spines on segments 6 to 9 , and laterodorsal tubes on segment 10 . The only taxonomically significant information provided beyond these spine/tube patterns is metric data (Table 5). The described spine/tube pattern fits about 20 currently known species of kinorhynchs, but if information on the rather short middorsal spines and long lateral terminal spines is 
taken into account, it narrows the field of similar species down to those that are addressed in the present contribution - species that we here refer to as the Echinoderes dujardini species group. It is, however, difficult to carry out a closer comparison with species of this group, because information on significant characters such as glandular cell outlets type 2, female papillae and certain sensory spots is unavailable for E. ehlersi. Without this information, E. ehlersi could potentially be conspecific with E. imperforatus, E. sensibilis, E. songae Sørensen \& Chang sp. nov., and obviously E. chandrasekharai Sørensen \& Chatterjee sp. nov. from the Andaman Islands, which would put a question mark to the validity of some or all of these species. However, it would be wrong to let an insufficiently described species stand in the way of several otherwise well-described species. Likewise, since detailed information is available for E. chandrasekharai Sørensen \& Chatterjee sp. nov., we would prefer to conserve this information in a species description, rather than letting the lack of information (about E. ehlersi morphology) serve as argument for considering E. chandrasekharai Sørensen \& Chatterjee sp. nov. and E. ehlersi to be conspecific. Hence, instead of letting the incomplete information about E. ehlersi morphology act as a brake for present days' taxonomy, we recommend that this species is not taken into account in taxonomic and systematic contributions, until it has been redescribed based on topotype material. The problem illustrated with E. ehlersi is not unique among species of Echinoderes, and similar recommendations will soon be provided for other insufficiently described species of the genus.

\section{Differential notes on $E$. imperforatus}

This species was described by Higgins (1983) from Carrie Bow Cay in Belize, and is so far the only Caribbean species of the E. dujardinii species group. The re-examination of the type material only revealed a few, but yet important, new characters for the species. These include the presence of glandular cell outlets type 2 in laterodorsal positions on segments 8 and 9, and ventromedial female papillae on segments 6 to 8. In the original description, Higgins (1983) stresses the apparent lack of cuticular perforation sites as an important diagnostic character for the species. This characteristic can only be partly supported by our observations. Perforation sites are truly indistinct in the species, but they are actually visible - especially on the ventral sides of segments 1 and 2 (Fig. 7C), but also on other segments (see, e.g., Fig. 7D). But the perforation sites are more indistinct than in most other echinoderid species, hence, the trait can at least be helpful in species identification, even though it has to be used with caution.

Echinoderes imperforatus belongs to the short spined species (i.e., species with middorsal spines not extending beyond their posterior segment margins) of the E. dujardinii group, which easily distinguishes it from the long spined species E. kozloffi, E. pacificus, E. sublicarum and Echinoderes sp. from the Andaman Islands (see also Table 20). The lack of lateral accessory tubes on segment 8 also easily distinguishes it from E. dujardinii and E. gerardi. This leaves E. sensibilis, E. songae Sørensen \& Chang sp. nov. and E. chandrasekharai Sørensen \& Chatterjee sp. nov. as the three species that show closest resemblance to $E$. imperforatus. The two new species can unambiguously be distinguished by the lack of glandular cell outlets type 2 on segment 9 in E. songae Sørensen \& Chang sp. nov., and the different positions and intracuticular structure of female papillae in E. chandrasekharai Sørensen \& Chatterjee sp. nov. (see Table 20). Echinoderes sensibilis and E. imperforatus are so similar that they can basically only be distinguished by the more distinct cuticular perforation sites of cuticular hairs in E. sensibilis. The only other difference we could identify is the lateral terminal spines that tend to be longer in E. imperforatus (compare overview photo on Fig. 7A and Fig. 14A). However, the ranges of spine lengths in the two species are actually slightly overlapping $(132-168 \mu \mathrm{m}$ in E. sensibilis (Table 11) vs 164-192 $\mu \mathrm{m}$ in E. imperforatus (Higgins 1983)), so this character is not convincing either. This leaves us with the feeling that $E$. sensibilis and E. imperforatus could indeed be conspecific. Only a couple of decades ago, the distance between the type localities of the two species - Japan and Belize - would in itself be a valid argument for seeing them as two distinct species, but recently we have seen examples of echinoderids with much larger, nearly panglobal, distributions (Sørensen et al. 2018). With the finding of E. sensibilis on Hawaii, the distributional ranges of the two species have indeed moved closer to 
each other, and conspecifity is certainly an option that should be kept in mind. However, based on the presently available information, we do not wish to make any taxonomic emending. Hence, for now we would consider E. sensibilis and E. imperforatus as two distinct species, but they should be subject for closer examination and comparison whenever fresh material for SEM and molecular sequencing becomes available for E. imperforatus.

\section{Differential notes on E. kozloffi, E. pacificus, E. sublicarum and Echinoderes sp. from the Anda- man Islands}

The four species E. kozloffi, E. pacificus, E. sublicarum and Echinoderes sp. from the Andaman Islands can together be referred to as the long spined species within the E. dujardinii species group. These species also share the presence of glandular cell outlets type 2 on segment 8 only, but this lack of type 2 outlets on segment 9 is also shared with the short spined species E. songae Sørensen \& Chang sp. nov. Despite their obvious similarities, the four long spined species can be recognized by some minor differences. Echinoderes pacificus is most easily distinguished by its conspicuously short, hornshaped midlateral tubes on segment 10 , and the shape of its lateral terminal spines that are thick in their proximal $1 / 3$, but taper abruptly into very thin distal $2 / 3$ end-pieces (Fig. $8 \mathrm{G}$ ). These two character traits are in particular important when distinguishing E. pacificus from E. sublicarum, because the two species otherwise are very similar. A special trait, shared only by these species, is the intracuticular substructure of their female papillae. Whereas the substructure in all other examined species appears to form either a tubular structure or a highly characteristic crescentic structure, both structures appear to be present in E. pacificus and E. sublicarum (Fig. 8D, F). In E. pacificus these combined crescentic structures connected with conspicuous tubes can be observed in ventrolateral positions on segment 7 , and in ventromedial positions on segment 8 . It should be stressed that we were only able to observe the similar structures on segment 8 in E. sublicarum, but in the original description of the species, Higgins (1977b) mentions the presence of these structures on both segment 7 and 8 . Hence, we believe that female papillae with this substructure actually are present on both segments, and that we only fail to confirm this because of the age and condition of the type specimens.

Echinoderes kozloffi and the yet undescribed species from the Andaman Islands can only be unambiguously distinguished from each other and from E. sublicarum by the shape and positions of their female papillae. Echinoderes kozloffi differs the most, by being the only species in the E. dujardinii species group with female papillae on segment 6 . The species furthermore differ from the long spined close relatives by having ventromedial female papillae on segment 8 with a crescentic substructure, but no tubular substructure. On the opposite, E. pacificus and E. sublicarum have, as mentioned above, both a crescentic and a tubular substructure, whereas Echinoderes sp. from the Andaman Islands only has a tubular substructure.

When comparing spine dimensions, E. sublicarum and E. pacificus seem to pair up again, as they are the two species with the longest middorsal spines. This is especially distinct on segment 8 where the middorsal spine reaches the midline of segment 10. On the opposite, the middorsal spine in E. kozloffi and Echinoderes sp. from the Andaman Islands only reaches the midline of segment 9.

\section{Differential notes on $E$. sensibilis}

With its distributional range extended considerably, from different localities in Japan and Korea to Hawaii, and with a range overlapping with at least two quite similar species, E. aureus and E. songae Sørensen \& Chang sp. nov., the need for consistent and reliable diagnostic characters for $E$. sensibilis is obvious. It is most easily distinguished from $E$. aureus by its shorter middorsal spines, the presence of glandular cell outlets type 2 on segments 8 and 9 , and by its different dorsal pattern of glandular cell outlets type 1 (presence of subdorsal outlets on segments 4 to 9 in E. sensibilis versus outlets switching between middorsal and paradorsal positions in E. aureus). Among the short spined species of 
the E. dujardinii group, E. sensibilis is most easily distinguished from E. dujardinii and E. gerardi by its lack of lateral accessory tubes on segment 8 , and from E. songae Sørensen \& Chang sp. nov. by the presence of glandular cell outlets type 2 on both segments 8 and 9 , opposite to outlets on segment 8 only in E. songae Sørensen \& Chang sp. nov. It furthermore differs from both E. songae Sørensen \& Chang sp. nov. and E. chandrasekharai Sørensen \& Chatterjee sp. nov. by having female papillae with tubular instead of crescentic substructure on segment 7 (see all differences summarized in Table 20). As noted above, E. sensibilis shows great resemblance with E. imperforatus, and currently the only differential character is the much more indistinct perforation sites in E. imperforatus.

One would obviously speculate if the conspicuous red-brown glands could be diagnostic for E. sensibilis, but we would consider this as unlikely. Most descriptions and available data on kinorhynch morphology are based on fixed animals where all colours (e.g., in eye spots and glands) have been lost, whereas information and in particular documented data based on live animals is extremely scarce. Hence, it is very likely that more species show different patterns of colouration. Interestingly, Zelinka (1928) also pictures E. dujardinii with red-brown coloured glands (see Zelinka 1928: pls 10.1 and 10.2), and MH noted a similar colouring of glands in E. kozloffi collected in Canada (Herranz, pers. obs.), which suggests that several or maybe even all species of the E. dujardinii group have this kind of colouring.

Differential notes on $E$. songae Sørensen \& Chang sp. nov.

The description of $E$. songae Sørensen \& Chang sp. nov. was mainly based on paratypes of $E$. lanceolatus, as well as numerous non-types identified as E. lanceolatus (see Table 14). The species is very easily recognized, as it is the only short spined (i.e., without any middorsal spines extending beyond the posterior border of their respective segments) member of the $E$. dujardinii group that lacks glandular cell outlets type on segment 9 .

It is furthermore the only short spined species without female papillae on segment 6 . Interestingly, the lack of female papillae is, together with the lack of glandular cell outlets type on segment 9 , shared with the long spined species, suggesting that $E$. songae Sørensen \& Chang sp. nov. represents an intermediate species between the short- and long spined ones in the E. dujardinii group.

\section{Differential notes on $E$. chandrasekharai Sørensen \& Chatterjee sp. nov. and an undescribed Echinoderes from the Andaman Islands}

From Havelock Island, Higgins \& Rao (1979) reported a total of sixteen specimens that they considered to be conspecific with E. ehlersi. Ten of these, five males and five females were deposited at the USNM and were made available for the present study. In their initial study, Higgins \& Rao (1979) reported that there seemed to be sexual dimorphism expressed in the spine lengths, but they also noted that this dimorphism appeared to be inconsistent and to occur reversed in two specimens. Our examinations in the present study reveal that the observed differences are not due to sexual dimorphism, but due to the mixing of two different species. One species, E. chandrasekharai Sørensen \& Chatterjee sp. nov., is characterized by very short middorsal spines, glandular cell outlets type 2 on segments 8 and 9 , and female papillae, both with crescentic substructure, in ventrolateral positions on segment 7 and in ventromedial positions on segment 8 . The other species, here reported as Echinoderes sp., is characterized by longer middorsal spines (especially on segment 8), glandular cell outlets type 2 on segment 8 only, and female papillae in ventromedial positions, with crescentic substructure on segment 7 and tubular substructure on segment 8 .

Since a few specimens of $E$. chandrasekharai Sørensen \& Chatterjee sp. nov. more recently were made available for SEM, we decided to provide a formal description of this species. The combination of the species' spine/tube pattern, length of middorsal spines and presence of glandular cell outlets type 2 on segments 8 and 9 clearly assigns the species to the E. dujardinii species group. Even though members of this species group generally have short middorsal spines, E. chandrasekharai Sørensen \& Chatterjee 
sp. nov. stands out with its exceptionally short middorsal spines, which not even reach the primary pectinate fringes of the segment where they attach. Only one other species, E. gerardi, has middorsal spines that are this short. However, E. gerardi has lateral accessory tubes on segment 8, which are not present in E. chandrasekharai Sørensen \& Chatterjee sp. nov. Other than the length of its middorsal spines, E. chandrasekharai Sørensen \& Chatterjee sp. nov. is the only short spined species of the group with female papillae showing a crescentic substructure on segment 8 .

Higgins \& Rao (1979) present a line art of the species they refer to as E. cf. ehlersi (see Higgins \& Rao 1972: fig. 2). The species illustrated in this figure represents E. chandrasekharai Sørensen \& Chatterjee sp. nov. The other species that Higgins \& Rao (1979) accidentally got mixed up with E. chandrasekharai Sørensen \& Chatterjee sp. nov., here reported as Echinoderes sp. from the Andaman Islands, clearly differs from E. chandrasekharai Sørensen \& Chatterjee sp. nov. by the characters mentioned above. Instead, the species' much longer middorsal spine on segment 8 and the presence of laterodorsal glandular cell outlet on segment 8 , but lack on segment 9 , suggest that it is closer to the long spined species of the E. dujardinii group, i.e., E. kozloff, E. pacificus and E. sublicarum. Without a complete mapping of sensory spots in Echinoderes sp. and E. sublicarum it is difficult to point out good differential characters, but it seems at least that the middorsal spines are longer in both E. kozloffi and E. sublicarum, compared to Echinoderes sp. Furthermore, it differs from E. kozloffi by lacking female papillae on segment 6, and from all three long spined species, by having ventromedial, opposite to ventrolateral, female papillae on segment 7 (see Table 20). This suggests that Echinoderes sp. from the Andaman Islands represent a yet undescribed species, but due to the age of the LM and the lack of SEM material, we would prefer not to provide a formal description of the species, until fresh material is available.

\section{Differential notes on examined species not belonging to the $\boldsymbol{E}$. dujardinii species group}

Among the species examined in the present study, four were initially considered as potential members of the E. dujardinii group, but subsequently not included. These species are E. aureus, E. gizoensis, E. pilosus, and $E$. worthingi. However, in all four cases the re-examinations revealed new, taxonomically significant characters, hence we will in the following present short comments on their differential characters in order to ensure easier and more exact identification of the species.

\section{Differential notes on $E$. aureus}

Identification of $E$. aureus was not at all straightforward, since it has a very common spine pattern, and only shows very few rare or unique characters. It is, however, easily distinguished from species of the E. dujardinii group by its lack of glandular cell outlets type 2 on segments 8 and 9 , and by its different dorsal pattern of glandular cell outlets type 1, i.e., paradorsal outlets on segments $4,6,8,9$, and middorsal outlets on segments 5 and 7 (see Table 20). Outside the E. dujardinii group, E. aureus shares spine/tube pattern with numerous echinoderid species, but only three of these also share the complete lack of glandular cell outlets type 2, i.e., E. spinifurca Sørensen et al., 2005, E. gizoensis and $E$. worthingi, of which the latter two are also included in the present study. A fourth candidate is E. steineri (Chitwood, 1951), but since this species is quite poorly and insufficiently described (see Chitwood 1951), we suggest that it - as was the case with E. ehlersi - is not considered in taxonomic comparisons until it has been collected again and redescribed properly. Another species that according to its original description has spine/tube patterns resembling those in E. aureus is E. krishnaswarmyi Higgins, 1985. Glandular cell outlets type 2 are not reported in the original description, but the line art indicates that such outlets are actually present in subdorsal or laterodorsal positions on segments 2 to 8 (see Higgins 1985: fig. 1b). As part of the general validation of diagnostic echinoderid characters for the interactive identification key by Yamasaki et al. (2020a), topotype specimens of E. krishnaswarmyi were examined, and the presence of glandular cell outlets type 2 on segments 2 to 8 was confirmed. 
Regarding the three species sharing a similar spine/tube pattern and also the lack of glandular cell outlets type 2, E. aureus is most easily distinguished from E. spinifurca. This species has long and acicular tergal extensions (which characterizes all species of the E. spinifurca group) that easily distinguishes it from E. aureus (Sørensen et al. 2005). Echinoderes gizoensis and E. worthingi are also addressed in more detail below. Both species differ from $E$. aureus in their dorsal pattern of glandular cell outlets type 1, and position of female papillae (see Table 20). Furthermore, E. gizoensis has rather different tergal extensions that taper into long flexible, seta-like tips, opposite to the stout, triangular pointed tips in E. aureus. Echinoderes worthingi can be distinguished from E. aureus, as well as most other echinoderids by its conspicuously long middorsal spine on segment 8 , being more than twice as long as the middorsal spine on segment 7 (Higgins 1985, but see also redescription in the present contribution).

Two relatively rare character traits found in E. aureus are the midventral intracuticular fissure on segment 2, and the very strong pectinate fringe between the tergal extensions (Fig. 1E, J). The midventral fissure on segment 2 was also reported in the original description (Adrianov et al. 2002a), and until that time such a fissure had not previously been observed in a species of Echinoderes. More recently, various levels of midventral division of segment 2 have been reported from other species of Echinoderes, including E. levanderi Karling, 1954, E. pennaki Higgins, 1960, and E. pilosus (see Herranz et al. 2018; Sørensen 2018; present study) as well as several other species (see interactive key of Yamasaki et al. (2020a) for summary) but it is still a relatively rare trait among species of Echinoderes, and especially in the beginning of the present study the midventral fissure was a help to distinguish $E$. aureus from species of the E. dujardinii group. Adrianov et al. (2002a) also illustrated the conspicuously strong pectinate fringe between the tergal extensions of E. aureus (see Fig. 1J), and so far we cannot think of any other species with a similar morphology. Hence, this trait can also be helpful in species recognition. Finally, Adrianov et al. (2002a) proposed the presence of paired intracuticular markings in ventromedial positions of segment 1 as a diagnostic character for E. aureus. In our re-examinations, we saw weak indications of such markings, but they are extremely indistinct (see, e.g., Fig. 1E) and often impossible to visualize, hence this character might not be that applicable in species recognition.

\section{Differential notes on $E$. gizoensis}

The re-examinations of E. gizoensis mostly resulted in a confirmation of the characters reported in the original description provided by Thormar \& Sørensen (2010). The only significant addition was the finding of female papillae with a tubular substructure in ventromedial positions on segment 7 . The species differs from species of the $E$. dujardinii group by its lack glandular cell outlets type 2 and by its tergal extensions that extend into seta-like tips.

\section{Differential notes on $E$. pilosus}

Echinoderes pilosus was redescribed by Higgins (1986), hence the present re-examinations mostly add to this redescription. The most significant new findings include the presence of an incomplete intracuticular fissure on the anterior half of segment 2, glandular cell outlets type 2 in subdorsal positions on segment 2 and laterodorsal positions on segments 8 and 9 , and female papillae in ventrolateral positions on segments 6 and 7 , and ventromedial positions on segment 8 . We can furthermore confirm the presence of two middorsal, longitudinally aligned glandular cell outlets type 1 on segment 1 (reported as "cuticular scars" by Higgins 1986), which appears to be uncommon among species of Echinoderes. The presence of subdorsal glandular cell outlets type 2 on segment 2 , the two middorsal type 1 outlets on segment 1 , the partial midventral fissure on segment 2 , as well as the rather slender and delicate spines and relatively thin cuticle all together suggests that the species is not part of the E. dujardinii group, and also easily distinguish it from any species of the group.

Echinoderes pilosus only shares spine/tube and glandular cell outlet type 2 pattern with four additional species, i.e., Echinoderes kohni Varney et al., 2019, E. lupherorum Sørensen et al., 2018, E. microaperturus 
Sørensen et al., 2012 and E. yamasakii Sørensen et al., 2018 (see Sørensen et al. 2012, 2018; Varney et al. 2019). However, these four species all belong to the Echinoderes spinifurca species group, which are characterized by species with conspicuous acicular tergal extensions (see Landers \& Sørensen 2018; Sørensen et al. 2018). This kind of tergal extensions differ considerably from the extremely short, barely visible tergal extensions of E. pilosus (see Fig. 10J). Echinoderes pilosus also differ from these, as well as most other echinoderids, by the shape of its trunk that tapers abruptly in the posterior end.

\section{Differential notes on $E$. worthingi}

Echinoderes worthingi was redescribed by Higgins (1985), hence the present re-examinations mostly add to this redescription. Significant new findings to be added to Higgins' (1985) redescription include the presence of female papillae in ventromedial positions of segments 7 and 8 , and the confirmed absence of glandular cell outlets type 2 . The species lack the seta-like extended fringe tips that seems to characterize all species of the E. dujardinii group (see Table 20), and even though E. worthingi and species of the $E$. dujardinii group share the presence of female papillae, the intracuticular substructure of those in E. worthingi differs. The cuticle surrounding the intracuticular parts of the female papillae in E. worthingi first of all appears to be way stronger than in any other examined species, and even though the shape is somewhat tubular, it is distally broader and rounded, giving the tube a spatulate appearance (Fig. 16G-H). This particular substructure seems so far to be unique for E. worthingi. However, besides this detail, the easiest way to identify the species is - as pointed out by Higgins (1985) - the middorsal spine of segment 8 that is more than twice as long as any other middorsal spine in the species.

\section{Ecology and habitat preferences of the $E$. dujardinii species group}

The vast majority of kinorhynchs are restricted to live in various kinds of muddy and silty sediments (Neuhaus 2013; Sørensen \& Pardos 2020). However, during the present study it was noted that most species of the E. dujardinii group appeared to have rather unusual substrate preferences, and for instance would appear on kelp or in epizoic growth on macroinvertebrates. Among the eleven species of the group, only E. dujardinii occurs in regular subtidal marine mud. Species such as E. kozloffi, E. pacificus and $E$. sensibilis also live in mud, but in all three cases in mud with high contents of organic matter (Schmidt 1974; Higgins 1977; Herranz \& Leander 2016; present study), which due to its high bacterial activity, decomposition processes and low oxygen concentrations is challenging for most meiofaunal organisms. Echinoderes dujardinii and E. imperforatus have both been collected from mud with sea grasses (Higgins 1983; present study), which is also typically a substrate with high contents of organic matter and low oxygen. Echinoderes gerardi, E. songae Sørensen \& Chang sp. nov. and E. sublicarum are known from sediment or growth on macroinvertebrates (Higgins, 1977b, 1978; present study), E. kozloffi, E. pilosus, E. sensibilis and E. songae Sørensen \& Chang sp. nov. from kelp or calcareous algae (Lang 1949; Adrianov et al. 2002b; Herranz \& Leander 2016; present study), and E. sensibilis and $E$. songae Sørensen \& Chang sp. nov. from intertidal rock surfaces (Yamasaki et al. 2014; present study). Furthermore, E. dujardinii, E. gerardi, E. imperforatus, E. songae Sørensen \& Chang sp. nov., E. chandrasekharai Sørensen \& Chatterjee sp. nov. and Echinoderes sp. from the Andaman Islands (Higgins 1983; present study) are also reported from sediments with mixed shells, sand and mud.

This suggests that species of the E. dujardinii group are highly opportunistic, and able to establish themselves in habitats that are too extreme for most other kinorhynch species. The ability to inhabit such unusual and in some ways extreme habitats must have played a role in the radiation of the E. dujardinii group species. The fact that all species in the group inhabit one or several different unusual habitats suggests that this opportunism already was present in the last common ancestor of the different species. We have other examples of kinorhynch genera being adapted to special habitats, such as the beach dwelling Cateria Gerlach, 1956 (Neuhaus \& Kegel 2015; Herranz et al. 2019), or the Echinoderes coulli species group that (mostly) includes species that are specialized in surviving in intertidal mudflats with highly fluctuating temperatures and salinity (Sørensen 2014; Yamasaki 2016; Randsø et al. 2019). 
However, the E. dujardinii group is the first known example of a kinorhynch clade for which one of the evolutionary drivers have been opportunism, rather than specialization.

This opportunism may also have an influence on the spreading potential of the species. Epizoic species can get carried around by their macroinvertebrate hosts, and species living in floating kelp can spread with the surface currents over large distances. This could be one of the explanations why distributional ranges of species such as E. sensibilis and E. songae Sørensen \& Chang sp. nov. overlap in Japan and Korea. Even though E. sensibilis has never been observed in macroalgae on Hawaii (macroalgae were not at any point examined during the workshop), it seems likely that the species managed to spread from East Asia to Hawaii with floating algae, or in growth on vessels sailing between Japan and Hawaii.

\section{Notes on morphological observations}

\section{Female papillae}

The presence of female papillae has only been reported rather sporadically in echinoderid literature, and so far they have never been considered taxonomically or phylogenetically significant. Early reports on female papillae can be found in descriptions from the 1970s, but here they would either be shown on line art only, without any mention in the text (Higgins 1977a), or be referred to as "bracket-shaped muscle scars" (Higgins 1977b), and in all cases without any notes about the structures being restricted to females. Neuhaus \& Blasche (2006) were the first to note that the structures were restricted to females, and described them as "gland cell outlets in females with subcuticular, funnel-shaped structures". Neuhaus \& Blasche (2006) described the echinoderid genus Fissuroderes, and provided descriptions for five species of this new genus that all were characterized by the presence of female papillae on the sternal plates of either segment 7 or 8 . They furthermore observed female papillae on segment 8 in the re-examined species Cephalorhyncha asiatica (Adrianov, 1989) and Cephalorhyncha nybakkeni (Higgins, 1986).

After Neuhaus \& Blasche (2006) provided the descriptions of the first five species of Fissuroderes, only two additional species have been added to the genus: F. sorenseni Herranz \& Pardos, 2013 and F. cthulhu Cepeda et al., 2020. Also, these species showed female papillae, on the sternal plates of segment 7 in F. cthulhu (see Cepeda et al. 2020), and on segments 7 and 8 in F. sorenseni (although note that Herranz \& Pardos 2013 refer to the papillae as "glandular cell outlets type 2 restricted to females"). Hence, female papillae are present in all species of Fissuroderes. Outside Fissuroderes, the reporting of female papillae in echinoderid species is rather sporadic, and since the structures still do not receive that much attention in taxonomic contributions, lacking information about the structures cannot be interpreted as confirmation of their absence.

During the preparation of the recently published interactive identification key for echinoderid kinorhynchs (Yamasaki et al. 2020a), the occurrence of female papillae was checked in several species. For the smaller echinoderid genera this resulted in positive confirmation of the presence of female papillae in following species: Polacanthoderes martinezi Sørensen, 2008, segments 6 to 7, and in Cephalorhyncha polunga Sánchez et al., 2019, segment 7. Absence of female papillae could be positively confirmed for Cephalorhyncha teresae Cepeda et al., 2019 and all species of Meristoderes Herranz et al., 2012. Presence of female papillae is likewise uncertain for the two small and laterally compressed species Cephalorhyncha liticola and C. flosculosa Yildiz et al., 2016.

For the species-rich genus Echinoderes the presence of female papillae are confirmed for all species included in the presence study (Table 20). From more recent studies we also have positive confirmation of female papillae from all species of the Echinoderes spinifurca group (see Landers \& Sørensen 2018; Sørensen et al. 2018; Varney et al. 2019), from E. multiporus Yamasaki et al., 2018 (segment 8) and in E. schwieringae Yamasaki et al., 2019 (segments 7-8) (see Yamasaki et al., 2018a, 2019). In addition 
to these, the interactive key of Yamasaki et al. (2020a) confirms the presence of female papillae in E. krishnaswarmyi (segments 7-8), E. neospinosus Gardóñez et al., 2008 (segments 7-8), and E. truncatus Higgins, 1983 (segments 6-8). During the preparation of the key, confirmation of absence of female papillae was also provided for a surprisingly high number of echinoderid species. Out of the 131 currently described species of Echinoderes, female papillae are lacking in 78 species, whereas their presence is uncertain for the remaining species (see key of Yamasaki et al. (2020a) for a more detailed overview).

In all echinoderid species, female papillae are restricted to appear as pairs in either ventrolateral or ventromedial positions on segments 6 to 8 . They can occur on all three segments, or on just two or one. Morphologically we also see some variation, in the outlet on the cuticular surface, and in the intracuticular substructure. The morphology of the outlet can only be observed with SEM. All species examined in the present study (those for which SEM material was available), have small rounded outlets resembling those of glandular cell outlets type 2 (Figs 4H, 6G-H, 10F, I, 15H-I, 17E, 21H insets, 24HI). Re-examination of unpublished SEM images of $F$. sorenseni and E. microaperturus, of which the latter belongs to the $E$. spinifurca group, also revealed the presence of minute, round openings from their female papilla. However, similar openings were not found in other species of the E. spinifurca group. This suggests that female papillae in some species might have outlets forming indistinct pore fields, somewhat similar to glandular cell outlets type 1 - or that we have failed to locate the openings.

In the present study we generally observed two distinct shapes of intracuticular substructures: the crescentic form, with a short nipple-like tube in the middle of the curved part (e.g., Fig. 23H), and the tubular substructure. Both substructures can appear on different segments in the same animal. In addition to these two general substructures we saw some variations of the tubular substructure that could vary in length, and in some cases get really short and broad, and take a nearly rhomboid shape. Another distinct variation of the tubular substructure is the spatulate shape found in $E$. worthingi (Fig. 16G-H). In E. pacificus and E. sublicarum we also observed a mix of the two shapes, where the minute, nipple on the crescentic substructure extends into an actual tubular substructure (Fig. 8D, F). The funnel-shaped substructures reported by Neuhaus \& Blasche (2006) in species of Fissuroderes are very similar to the tubular substructures reported in the present study. Across echinoderid species this appears to be the most common substructure. However, the female papillae on segments 6 to 8 in E. truncatus clearly have the crescentic substructure (Sørensen \& Herranz, unpubl. obs.).

The function, morphological variation and taxonomic significance of female papillae are yet to be fully understood. However, the present study clearly demonstrates that the presence, position and intracuticular substructure of female papillae can be very helpful in species distinction, which stresses that the structures do play a role in taxonomy. The phylogenetic significance of the structures also needs to be explored further, but the consistent appearance of female papillae in two putatively monophyletic groups, the E. dujardinii group and E. spinifurca group, and their lack in the E. coulli group suggest that the structure could reflect parts of echinoderid evolution also. In any case, we would like to stress the importance of reporting occurrence, position and morphology of female papillae in future taxonomic studies, and of equal importance, provide positive confirmation of their absence in species lacking these structures.

\section{Patterns of glandular cell outlets type 1}

Taxonomic contributions of the recent decade have clearly showed the taxonomic significance of glandular cell outlets type 2 . The presence of the structures were first used as a taxonomic character by Neuhaus \& Blasche (2006), and since then they have become a standard element in most taxonomic descriptions of echinoderid kinorhynchs (e.g., Sørensen et al. 2012, 2016, 2018; Sørensen \& Landers 2014; Yamasaki \& Fujimoto 2014; Pardos et al. 2016a, 2016b; Yamasaki et al. 2018a, 2019). Within 
the same period, the occurrence of glandular cell outlets type 1 has also been included as a standard component in most echinoderid descriptions, but opposite to the type 2 outlets, the applicability of type 1 outlets as taxonomic characters has never really been tested.

During the present study we initially experienced difficulties distinguishing E. aureus from some of the East Asian species, such as E. sensibilis and E. songae Sørensen \& Chang sp. nov. However, we realized that the dorsal pattern of glandular cell outlets type 1 on segments 1 to 9 in $E$. aureus differed significantly from the pattern in species of the $E$. dujardinii group, and that the dorsal pattern did not vary between species within the group. This inspired us to look more closely into the patterns of glandular cell outlets type 1 across the echinoderid species.

Among echinoderid species, the ventral patterns of glandular cell outlets type 1 seem to be extremely conserved, and nearly follow the same stereotypical distribution, i.e., a pair of outlets on segment 1 in sublateral to ventromedial positions, and ventromedial pairs on segments 2 to 10 . This pattern seems to be so consistent that it is not suitable for species distinction or recognition of species groups. Also, the dorsal side of segment 10 appears to show the same distribution of type 1 outlets in most echinoderid species, i.e., two middorsal, longitudinally aligned outlets. Hence, the variation that can provide us with significant information is restricted to the dorsal series on segment 1 to 9 .

It is currently not possible to provide a full overview of dorsal type 1 outlet patterns in all echinoderids. Older descriptions tend to mix the nature of cuticular structures, such as glandular cell outlets type 1, sensory spots and muscular attachment sites, and even in more recent species descriptions information on type 1 outlets is sometimes missing because the structures are too difficult to visualize. However, an initial exploration of information provided in the taxonomic literature revealed some interesting trends and patterns. Information about dorsal type 1 outlet patterns was checked for 152 species of Echinoderidae. Out of these, information was either missing or too incomplete for 67 species, but this still left us with valid information from 85 species. Among these 85 species we listed the different patterns of dorsal type 1 outlets, in an attempt to identify particular patterns that would characterize larger groups of species. We could identify a total of 18 different patterns, of which 15 were found in only one to three species. This left us with three patterns that characterized larger groups (Table 21).

The least common pattern of the three was the one found in species of the E. dujardinii group, i.e., middorsal outlets on segment 1 to 3 , and subdorsal ones on segments 4 to 9 . This pattern is present in the ten E. dujardinii species for which information is available (see Tables 20-21), as well as in E. worthingi, and, perhaps a little surprisingly, in Cephalorhyncha nybakkeni (see Neuhaus \& Blasche 2006).

The two most common patterns are found in an equal number of species, i.e., 27 (Table 21). One of these has already been mentioned previously, namely the pattern found in E. aureus with middorsal outlets on segments 1 to 3, 5 and 7, and in paradorsal positions on segments 4, 6, and 8 to 9 . This pattern was found in 22 species of Echinoderes, in Fissuroderes sorenseni, and in four species of Meristoderes (see Table 21 for all species and references). The other very common pattern shows middorsal outlets on segments 1 to 3, and in paradorsal positions on segments 4 to 9. This pattern was also found in 22 species of Echinoderes, in Cephalorhyncha polunga, Fissuroderes higginsi Neuhaus in Neuhaus \& Blasche, 2006, F. novaezealandia Neuhaus in Neuhaus \& Blasche, 2006, Meristoderes taro Sánchez et al., 2019, and in Polacanthoderes martinezi (see Table 21 for all species and references).

The different patterns of dorsal type 1 outlets most probably show some homoplasy, as it is obviously the case with some spine/tube patterns also. However, there might still be hidden clues to understand echinoderid phylogeny. At least the pattern found nearly exclusively among species of the E. dujardinii group suggests that this particular distribution of outlets has phylogenetic significance. It is furthermore 
Table 21. The three most common echinoderid dorsal patterns of glandular cell outlets type 1 on segments 1 to 9. Literature sources: Higgins 1982, 1983; Higgins \& Kristensen 1988; Huys \& Coomans 1989; Adrianov \& Malakhov 1999; Adrianov et al., 2002a; Neuhaus \& Blasche 2006; Sørensen 2008, 2014, 2018; Thormar \& Sørensen 2010; Herranz et al. 2012, 2014, 2018; Sørensen et al. 2012, 2013, 2016, 2018; Yamasaki \& Kajihara 2012; Herranz \& Pardos 2013; Sørensen \& Landers 2014; Pardos et al. 2016b; Yamasaki 2016; Yamasaki \& Durucan, 2018; Yamasaki et al. 2018a, 2018b, 2019, 2020b; Cepeda et al. 2019b, 2019c; Grzelak \& Sørensen 2019; Sánchez et al. 2019; Yamasaki \& Dal Zotto 2019; present study.

\begin{tabular}{|c|c|c|c|}
\hline $\begin{array}{l}\text { Position }+ \\
\text { segment number }\end{array}$ & $\begin{array}{l}\text { MD Seg. 1-3 } \\
\text { SD Seg. } 4-9\end{array}$ & $\begin{array}{l}\text { MD Seg. } 1-3 \\
\text { PD Seg. } 4-9\end{array}$ & $\begin{array}{l}\text { MD Seg. } 1-3,5,7 \\
\text { PD Seg. 4, 6, 8-9 }\end{array}$ \\
\hline \multicolumn{2}{|c|}{$\begin{array}{l}\text { Cephalorhyncha nybakkeni } \\
\text { (Higgins, 1986) }\end{array}$} & Cephalorhyncha polunga Sánchez et al., 2019 & Echinoderes abbreviatus Higgins, 1983 \\
\hline \multicolumn{2}{|c|}{ Echinoderes chandrasekharai sp. nov.. } & Echinoderes angustus Higgins \& Kristensen, 1988 & $\begin{array}{l}\text { E. antalyaensis } \\
\text { Yamasaki \& Durucan, } 2018\end{array}$ \\
\hline \multicolumn{2}{|c|}{ E. dujardinii Claparède, 1863} & E. aquilonius Higgins \& Kristensen, 1988 & E. apex Yamasaki et al., 2018 \\
\hline \multicolumn{2}{|c|}{ E. gerardi Higgins, 1978} & E. barbadensis Cepeda et al., 2019 & E. arlis Higgins, 1966 \\
\hline \multicolumn{2}{|c|}{ E. imperforatus Higgins, 1983} & E. bookhouti Higgins, 1964 & E. astridae Sørensen, 2014 \\
\hline \multicolumn{2}{|c|}{ E. kozloffi Higgins, 1977} & E. ferrugineus Zelinka, 1928 & E. augustae Sørensen \& Landers, 2015 \\
\hline \multicolumn{2}{|c|}{ E. pacificus Schmidt, 1974} & E. gama Yamasaki et al., 2020 & E. aureus Adrianov et al., 2002 \\
\hline \multicolumn{2}{|c|}{ E. sensibilis Adrianov et al., 2002} & E. juliae Sørensen et al., 2018 & E. bermudensis Higgins, 1982 \\
\hline \multicolumn{2}{|l|}{ E. songae sp. nov. } & E. kaempfae Yamasaki et al., 2019 & E. bispinosus Higgins, 1982 \\
\hline \multicolumn{2}{|c|}{ E. sublicarum Higgins, 1977} & E. kajiharai Yamasaki et al., 2020 & E. brevipes Cepeda et al., 2019 \\
\hline \multicolumn{2}{|c|}{ E. worthingi Southern, 1914} & E. kanni Thormar \& Sørensen, 2010 & E. capitatus Zelinka, 1928 \\
\hline \multirow{16}{*}{\multicolumn{2}{|c|}{ Echinoderes sp. Andaman Isl. }} & E. levanderi Karling, 1954 & E. hakaiensis Herranz et al., 2018 \\
\hline & & E. marthae Sørensen, 2014 & E. hamiltonorum Sørensen et al., 2018 \\
\hline & & E. muricatus Pardos et al., 2016 & E. higginsi Huys \& Coomans, 1989 \\
\hline & & E. ohtsukai Yamasaki \& Kajihara, 2012 & E. horni Higgins, 1983 \\
\hline & & E. pennaki Higgins, 1960 & E. multiporus Yamasaki et al. 2018 \\
\hline & & E. regina Yamasaki, 2016 & E. parahorni Cepeda et al. 2019 \\
\hline & & E. schwieringae Yamasaki et al., 2019 & E. peterseni Higgins \& Kristensen, 1988 \\
\hline & & E. serratulus Yamasaki, 2016 & E. riceae Herranz et al., 2014 \\
\hline & & E. svetlanae Adrianov, 1999 & E. unispinosus Yamasaki et al., 2018 \\
\hline & & E. tchefouensis Lou, 1934 & E. uozumii Yamasaki et al., 2020 \\
\hline & & E. tubilak Higgins \& Kristensen, 1988 & E. wallaceae Higgins, 1983 \\
\hline & & E. xalkutaat Cepeda et al., 2019 & $\begin{array}{l}\text { Fissuroderes sorenseni Herranz \& Pardos, } \\
2013\end{array}$ \\
\hline & & Fissuroderes higginsi Neuhaus \& Blasche, 2006 & $\begin{array}{l}\text { Meristoderes boylei Herranz \& Pardos, } \\
2013\end{array}$ \\
\hline & & F. novaezealandia Neuhaus \& Blasche, 2006 & M. galatheae Herranz et al., 2012 \\
\hline & & Meristoderes taro Sánchez et al., 2019 & M. herranzae Sørensen et al., 2013 \\
\hline & & Polacanthoderes martinezi Sørensen, 2008 & M. macracanthus Herranz et al., 2012 \\
\hline
\end{tabular}


not unlikely that the only additional species of Echinoderes showing this pattern, i.e., E. worthingi, is closely related with the E. dujardinii group, even though we would not consider it to be part of the group. The presence of this pattern in C. nybakkeni appears to be a result of convergent evolution.

Currently, we know very little about the remaining species sharing similar outlet patterns, but still we can observe some interesting trends. Among species sharing the pattern found in E. aureus, we can for instance observe E. horni Higgins, 1983 and E. parahorni Cepeda et al., 2019 that most likely are very closely related, and basically only can be distinguished by the presence of subdorsal glandular cell outlets type 2 on segment 2 in E. parahorni (Higgins 1983; Cepeda et al. 2019c). This is also the case for E. astridae Sørensen, 2014, E. bispinosus Higgins, 1982 and E. uozumii Yamasaki et al., 2020 that only differ by a pair of sublateral tubes on segment 8, present in E. astridae and E. uozumii only, and the conspicuously blunt and short pectinate fringe teeth on the posterior segments margin of segment 1, present in E. uozumii only (Higgins 1982; Sørensen 2014; Yamasaki et al. 2020b). It is also noteworthy that most species of Meristoderes show this particular dorsal pattern of outlets. Likewise, we see some putatively closely related species sharing the pattern with middorsal outlets on segments 1 to 3 , and paradorsal outlets on segments 4 to 9 . This includes for instance the extremely similar species E. angustus Higgins \& Kristensen, 1988, E. aquilonius Higgins \& Kristensen, 1988, and E. pennaki Higgins, 1960 (see Higgins \& Kristensen, 1988; Grzelak \& Sørensen 2018; Herranz et al. 2018), and the putative sister-species E. svetlanae Adrianov in Adrianov \& Malakhov, 1999 and E. tubilak Higgins \& Kristensen, 1988 (see Higgins \& Kristensen, 1988; Adrianov \& Malakhov 1999; Grzelak \& Sørensen 2018).

We are still far from understanding the taxonomic and phylogenetic significance of the dorsal patterns of glandular cell outlets type 1, but the present study shows that these patterns might be of greater importance than we knew about previously. Hence, we would suggest that future taxonomic contributions put more emphasis on this trait, and carry out comparisons with species showing similar patterns.

\section{Conclusions}

Thirteen species of Echinoderes were compared, and re-examined if material was available, which led to the following conclusions: 1) the holotype of Echinoderes lanceolatus is identical with Echinoderes aureus, and the species should therefore be considered a junior synonym of E. aureus. 2) Many paratypes of E. lanceolatus represented a different species though, that is described as E. songae Sørensen \& Chang sp. nov. 3) Echinoderes ehlersi is so insufficiently described that a redescription of topotype material is required before the species should be considered for taxonomic comparison. 4) Specimens from the Andaman Islands in India, previously reported as Echinoderes cf. ehlersi by Higgins \& Rao (1979) represent two different species, of which one is described as E. chandrasekharai Sørensen \& Chatterjee sp. nov., whereas the other, due to the limited material available, for now is left undescribed, as Echinoderes sp. from the Andaman Islands.

Based on these re-examinations and revisions, it was proposed that following species make up a putatively monophyletic group, named the Echinoderes dujardinii group: E. dujardinii, E. ehlersi, E. gerardi, E. imperforatus, E. sensibilis, E. songae Sørensen \& Chang sp. nov., E. chandrasekharai Sørensen \& Chatterjee sp. nov., Echinoderes sp. from the Andaman Islands, E. kozloffi, E. pacificus, and E. sublicarum, of which the three latter appear to be more closely related and either make up the root of the species group, or a monophyletic ingroup. The E. dujardinii group is supported by following character combinations: 1) similar spine/tube patterns, i.e., middorsal spines on segments 4 to 8 , lateroventral/ventrolateral tubes on segment 2 , lateroventral tubes on segment 5 , lateroventral spines on segments 6 to 9, laterodorsal or midlateral tubes on segment 10; lateral accessory tubes may or may not be present on segment 8. 2) Short middorsal spines, where those of segments 4 to 6 rarely extend beyond the posterior margin of their respective segments. 3) Glandular cell outlets type 1 are 
always present in middorsal positions on segments 1 to 3 , and in subdorsal positions on segments 4 to 9 . 4) Glandular cell outlets type 2 always present in laterodorsal or midlateral positions on segment 8 , and often, but not always, present in same positions on segment 9; type 2 outlets are never present on any other segments or in any other positions. 5) Female papillae are always present on sternal plates of segments 7 and 8, and occasionally also on segment 6. 6) Tergal extensions are well-spaced, triangular, gradually tapered cones. 7) Pectinate fringe of sternal extensions are differentiated into seta-like tufts. Additional examined species included E. aureus, E. gizoensis, E. pilosus and E. worthingi but none of these were considered to be part of the $E$. dujardinii species group. A similar pattern of glandular cell outlets type 1 on the dorsal side of segments 1 to 9 could however suggest that $E$. worthingi is closely related with the species group.

The revision initiated a closer examination of two kinds of cuticular structures that so far have not received much attention in taxonomic studies, i.e., female papillae on the sternal plates on segments 6 to 8 , and the dorsal pattern of glandular cell outlets type 1 on segments 1 to 9 . It was concluded that both characters are of greater taxonomic significance than previously assumed, and can be helpful in species identification as well as identifying groups of closely related species.

\section{Acknowledgements}

We would like to thank the Hawai'i Institute of Marine Biology, Coconut Island, Oahu, for hosting the MarineGEO Hawaii Biodiversity Assessment Workshop in 2017. We also thank the Invertebrate Collection of the Hokkaido University Museum, the Natural History Museum of Ewha Woman's University, Natural History Museum of Denmark, Seto Marine Biological Laboratory, Smithsonian Institution, the Swedish Museum of Natural History, and the F. Pardos lab at the Complutense University of Madrid for loaning specimens for the study. RCN and MH dedicate their sampling efforts in Faro, Portugal, to the memory of Prof. Dr Heinrich Reichert, who financially supported the field trip to Faro; they furthermore send their thanks to the staff from CCMAR (University of Algarve, Portugal). NÖY sends her thanks to the Dr S. Karaytug lab at Mersin University, Turkey, for their help with the Aegean Sea sampling, HY thanks Dr B. Neuhaus for his help loaning the E. pilosus type material, and MVS sends special thanks to Kathryn Ahlfeld for handling the large loans from the Smithsonian Institution, and for patiently extending these loans. Molecular work at the Smithsonian Institution was supported by the Global Genome Initiative under Award No. GGI-Partnership-2017-159b and performed at the Laboratory of Analytical Biology of the National Museum of Natural History. Sampling was supported by numerous sponsors and funding agencies: Hawaii sampling: The Castle Foundation, Matthew Frank Foundation, The Zilber Family Foundation, The Tennenbaum Marine Observatory Network and Global Genome Initiative (two latter via the Smithsonian Institution); Korea sampling to CYC: National Institute of Biological Resources (NIBR) 2011 grant, "Discovery of indigenous species from Korea"; Faro, Portugal sampling to RCN and MH: ASSEMBLE Grant No. 227799; Tanabe Bay, Japan sampling to HY: Japan Society for the Promotion of Science KAKENHI grant (23370038); Tanegashima, Japan sampling to HY: University of the Ryukyus Strategic Research Promotion Grant.

\section{References}

Adrianov A.V. \& Malakhov V.V. 1999. Cephalorhyncha of the world ocean. KMK Scientific Press, Moscow.

Adrianov A.V., Murakami C. \& Shirayama Y. 2002a. Echinoderes aureus n. sp. (Kinorhyncha: Cyclorhagida) from Tanabe Bay (Honshu) - first representative of the genus in the Pacific Ocean. Proceedings of the Biological Society of Washington 115: 205-216. 
Adrianov A.V., Murakami C. \& Shirayama Y. 2002b. Taxonomic study of the Kinorhyncha in Japan. III. Echinoderes sensibilis n. sp. (Kinorhyncha: Cyclorhagida) from Tanabe Bay. Zoological Science 19: 463-473. https://doi.org/10.2108/zsj.19.463

Cepeda D., Pardos F. \& Sánchez N. 2019a. Kinorhyncha from the Caribbean, with the description of two new species from Puerto Rico and Barbados. Zoologischer Anzeiger 282: 127-139.

https://doi.org/10.1016/j.jcz.2019.05.014

Cepeda D., Álvarez-Castillo L., Hermoso-Salazar M., Sánchez N., Gómez S. \& Pardos F. 2019b. Four new species of Kinorhyncha from the Gulf of California, eastern Pacific Ocean. Zoologischer Anzeiger 282: 140-160. https://doi.org/10.1016/j.jcz.2019.05.011

Cepeda D., Sánchez N. \& Pardos F. 2019c. First extensive account of the phylum Kinorhyncha from Haiti and the Dominican Republic (Caribbean Sea), with the description of four new species. Marine Biodiversity 49: 2281-2309. https://doi.org/10.1007/s12526-019-00963-x

Cepeda D., Pardos F., Zeppilli D. \& Sánchez N. 2020. Dragons of the deep sea: Kinorhyncha communities in a pockmark field at Mozambique Channel, with the description of three new species. Frontiers in Marine Science 7: e665. https://doi.org/10.3389/fmars.2020.00665

Chang C.Y. \& Song Y. H. 2002. Echinoderes lanceolatus, a new kinorhynch from Korea (Kinorhyncha, Cyclorhagida, Echinoderidae). The Korean Journal of Systematic Zoology 18: 203-211.

Chatterjee T. 2019. A review note on studies of Kinorhyncha from India. Cahiers de Biologie marine 60: 183-188. https://doi.org/10.21411/CBM.A.57675B01

Chitwood B.G. 1951. Echinoderella steineri new species (Scolecida, Echinodera). The Texas Journal of Science 1: 113-114.

Claparède A.R.E. 1863. Zur Kenntnis der Gattung Echinoderes Duj. In: Beobachtungen über Anatomie und Entwicklungsgeschichte wirbelloser Thiere an der Küste von Normandie angestellt: 90-92, 119. Wilhelm Engelmann, Leipzig. https://doi.org/10.5962/bhl.title.10030

Dal Zotto M. \& Todaro A. 2016. Kinorhyncha from Italy, a revision of the current checklist and an account of the recent investigations. Zoologischer Anzeiger 265: 90-107. https://doi.org/10.1016/j.jcz.2016.01.004

Di Domenico M. \& Sørensen M.V. 2019. Fifth International Scalidophora Workshop. Zoologischer Anzeiger 282: 1-2. https://doi.org/10.1016/j.jcz.2019.06.002

Dujardin F. 1851. Sur un petit animal marin, l'Echinodère, formant un type intermédiaire entre les Crustacés et les Vers. Annales des Sciences naturelles Zoologie 15 : 158-173.

Dunn C.W., Hejnol A., Matus D.Q., Pang K., Browne W.E., Smith S.A., Seaver E., Rouse G.W., Obst M., Edgecombe G.D., Sørensen M.V., Haddock S.H.D., Schmidt-Rhaesa A., Okusu A., Kristensen R.M.,Wheeler W.C., Martindale M.Q. \& Giribet G. 2008. Broad phylogenomic sampling improves resolution of the animal tree of life. Nature 452: 745-749.

https://doi.org/10.1038/nature06614

Grzelak K. \& Sørensen M.V. 2018. New species of Echinoderes (Kinorhyncha: Cyclorhagida) from Spitsbergen, with additional information about known Arctic species. Marine Biology Research 14: 113-147. https://doi.org/10.1080/17451000.2017.1367096

Grzelak K. \& Sørensen M.V. 2019. Diversity and distribution of Arctic Echinoderes species (Kinorhyncha: Cyclorhagida), with the description of one new species and a redescription of E. arlis Higgins, 1966. Marine Biodiversity 49: 1131-1150. https://doi.org/10.1007/s12526-018-0889-2 
Herranz M. \& Leander B. 2016. Redescription of Echinoderes ohtsukai Yamasaki and Kajihara, 2012 and E. kozloffi Higgins, 1977 from the northeastern Pacific coast, including the first report of a potential invasive species of kinorhynch. Zoologischer Anzeiger 265: 108-126. https://doi.org/10.1016/j.jcz.2016.02.004

Herranz M. \& Pardos F. 2013. Fissuroderes sorenseni sp. nov. and Meristoderes boylei sp. nov.: first Atlantic recording of two rare kinorhynch genera, with new identification keys. Zoologischer Anzeiger 253: 93-111 https://doi.org/10.1016/j.jcz.2013.09.005

Herranz M., Thormar J., Benito J., Sánchez N. \& Pardos F. 2012. Meristoderes gen. nov., a new kinorhynch genus, with the description of two new species and their implications for echinoderid phylogeny (Kinorhyncha: Cyclorhagida, Echinoderidae). Zoologischer Anzeiger 251: 191-179.

https://doi.org/10.1016/j.jcz.2011.08.004

Herranz M., Sánchez N., Pardos F. \& Higgins R.P. 2014. New Kinorhyncha from Florida coastal waters. Helgoland Marine Research 68: 59-87. https://doi.org/10.1007/s10152-013-0369-9

Herranz M., Yangel E. \& Leander B. 2018. Echinoderes hakaiensis sp. nov.: a new mud dragon (Kinorhyncha, Echinoderidae) from the northeastern Pacific Ocean with the redescription of Echinoderes pennaki Higgins, 1960. Marine Biodiversity 48: 303-325. https://doi.org/10.1007/s12526-017-0726-Z

Herranz M., Di Domenico M., Sørensen M.V. \& Leander B. 2019. The enigmatic kinorhynch Cateria styx Gerlach, 1956 - A sticky son of a beach. Zoologischer Anzeiger 282: 10-30.

https://doi.org/10.1016/j.jcz.2019.05.016

Higgins R.P. 1977a. Redescription of Echinoderes dujardinii (Kinorhyncha) with descriptions of closely related species. Smithsonian Contributions to Zoology 248: 1-26.

https://doi.org/10.5479/si.00810282.248

Higgins R.P. 1977b. Two new species of Echinoderes (Kinorhyncha) from South Carolina. Transactions of the American Microscopical Society 96: 340-354. https://doi.org/10.2307/3225864

Higgins R.P. 1978. Echinoderes gerardi n. sp. and E. riedli (Kinorhyncha) from the Gulf of Tunis. Transactions of the American Microscopical Society 97: 171-180. https://doi.org/10.2307/3225589

Higgins R.P. 1982. Three new species of Kinorhyncha from Bermuda. Transactions of the American Microscopical Society 101: 305-316. https://doi.org/10.2307/3225748

Higgins R.P. 1983. The Atlantic barrier reef ecosystem at Carrie Bow Cay, Belize, II. Kinorhyncha. Smithsonian Contributions to Marine Science 18: 1-131. https://doi.org/10.5479/si.01960768.18.1

Higgins R.P. 1985. The genus Echinoderes (Kinorhyncha, Cyclorhagida) from the English Channel. Journal of the Marine Biological Association of the United Kingdom 65: 785-800.

https://doi.org/10.1017/S0025315400052590

Higgins R.P. 1986. Redescription of Echinoderes pilosus (Kinorhyncha: Cyclorhagida). Proceedings of the Biological Society of Washington 99: 399-405.

Available from https://www.biodiversitylibrary.org/part/45462\#/summary [accessed 27 Nov. 2020].

Higgins R.P. 1988. Kinorhyncha. In: Higgins R.P. \& Thiel H. (eds) Introduction to the Study of Meiofauna: 328-331. Smithsonian Institution Press, Washington.

Higgins R.P. \& Kristensen R.M. 1988. Kinorhyncha from Disko Island, West Greenland. Smithsonian Contributions to Zoology 458: 1-56. https://doi.org/10.5479/si.00810282.458

Higgins R.P. \& Rao G.C. 1979. Kinorhynchs from the Andaman Islands. Zoological Journal of the Linnean Society 67: 75-85. https://doi.org/10.1111/j.1096-3642.1979.tb01106.x

Huys R. \& Coomans A. 1989. Echinoderes higginsi sp. n. (Kinorhyncha, Cyclorhagida) from the southern North Sea with a key to the genus Echinoderes Claparède. Zoologica Scripta 18: 211-221. https://doi.org/10.1111/j.1463-6409.1989.tb00446.x 
Kozloff E.N. 1972. Some aspects of development in Echinoderes (Kinorhyncha). Transactions of the American Microscopical Society 91: 119-130. https://doi.org/10.2307/3225404

Landers S.C. \& Sørensen M.V. 2018. Echinoderes sylviae n. sp. (Kinorhyncha, Cyclorhagida), from the Gulf of Mexico, with comparative notes on a similar species Echinoderes spinifurca. Bulletin of Marine Science 94: 1499-1514. https://doi.org/10.5343/bms.2017.1167

Lang K. 1949. Echinoderida. In: Odhner N.H. (ed.) Further Zoological Results of the Swedish Antarctic Expedition 1901-1903, Vol. 4: 1-22. P.A. Norstedt \& Söner, Stockholm.

Mari M. \& Morselli I. 1987. Acari (Alacaridi ed Idracnelle) e Chinorinchi nella spugna Hymeniacidon sanguinea (Grant) della Laguna Veneta. Atti della Societa dei Naturalisti e Matematici de Modena 118: $115-117$.

Neuhaus B. 2013. Kinorhyncha (= Echinodera). In: Schmidt-Rhaesa A. (ed.) Handbook of Zoology. Gastrotricha, Cycloneuralia and Gnathifera. Vol. 1: Nematomorpha, Priapulida, Kinorhyncha, Loricifera: 181-348. De Gruyter, Berlin/Boston.

Neuhaus B. \& Blasche T. 2006. Fissuroderes, a new genus of Kinorhyncha (Cyclorhagida) from the deep sea and continental shelf of New Zealand and from the continental shelf of Costa Rica. Zoologischer Anzeiger 245: 19-52. https://doi.org/10.1016/j.jcz.2006.03.003

Neuhaus B. \& Kegel A. 2015. Redescription of Cateria gerlachi (Kinorhyncha, Cyclorhagida) from Sri Lanka and of C. styx from Brazil, with notes on C. gerlachi from India and C. styx from Chile, and the ground pattern of the genus. Zootaxa 3965: 1-77. https://doi.org/10.11646/zootaxa.3965.1.1

Pardos F., Higgins R.P. \& Benito J. 1998. Two new Echinoderes (Kinorhyncha, Cyclorhagida) including a reevaluation of kinorhynch taxonomic characters. Zoologischer Anzeiger 237: 195-208.

Pardos F., Herranz M. \& Sánchez N. 2016a. Two sides of a coin: the phylum Kinorhyncha in Panama. I) Caribbean Panama. Zoologischer Anzeiger 265: 3-25. https://doi.org/10.1016/j.jcz.2016.06.005

Pardos F., Herranz M. \& Sánchez N. 2016b. Two sides of a coin: the phylum Kinorhyncha in Panama. II) Pacific Panama. Zoologischer Anzeiger 265: 26-47. https://doi.org/10.1016/j.jcz.2016.06.006

Randsø P.V., Yamasaki H., Bownes S.J., Herranz M., Di Domenico M., Qii G.B. \& Sørensen M.V. 2019. Phylogeny of the Echinoderes coulli-group (Kinorhyncha: Cyclorhagida: Echinoderidae) a cosmopolitan species group trapped in the intertidal. Invertebrate Systematics 33: 501-517.

https://doi.org/10.1071/IS18069

Sánchez N., Herranz M., Benito J. \& Pardos F. 2012. Kinorhyncha from the Iberian Peninsula: new data from the first intensive sampling campaigns. Zootaxa 3402: 24-44.

https://doi.org/10.11646/zootaxa.3402.1.2

Sánchez N., Pardos F. \& Martínez Arbizu P. 2019. Deep-sea Kinorhyncha diversity from the polymetallic nodule fields at the Clarion-Clipperton Fracture Zone (CCZ). Zoologischer Anzeiger 282: 88-105.

https://doi.org/10.1016/j.jcz.2019.05.007

Sánchez-Tocino L., Tierno de Figueroa J.M., López-Rodríguez M.J. \& Liébanas G. 2011. First record of Echinoderes dujardinii Claparède, 1863 (Kinorhyncha, Cyclorhagida) in Iberian Peninsula coastal waters. Zoologica Baetica 22: 179-184.

Schmidt P. 1974. Interstitielle Fauna von Galapagos. 10. Kinorhyncha. Microfauna des Meeresbodens 43: $1-15$.

Sönmez S., Köroğlu N.Ö. \& Karaytuğ S. 2016. First record of Family Echinoderidae Zelinka, 1894 (Kinorhyncha: Cyclorhagida) from Turkish marine waters. Biharean Biologist 10: 8-11. 
Sørensen M.V. 2008. A new kinorhynch genus from the Antarctic deep sea and a new species of Cephalorhyncha from Hawaii (Kinorhyncha: Cyclorhagida: Echinoderidae). Organism Diversity \& Evolution 8: 233-246. https://doi.org/10.1016/j.ode.2007.11.003

Sørensen M.V. 2014. First account of echinoderid kinorhynchs from Brazil, with the description of three new species. Marine Biodiversity 44: 251-274. https://doi.org/10.1007/s12526-013-0181-4

Sørensen M.V. 2018. Redescription of Echinoderes levanderi Karling, 1954 (Kinorhyncha: Cyclorhagida) - a kinorhynch tolerant to very low salinities. European Journal of Taxonomy 436: 1-17.

https://doi.org/10.5852/ejt.2018.436

Sørensen M.V. \& Landers S.C. 2014. Two new species of Echinoderes (Kinorhyncha: Cyclorhagida) from the Gulf of Mexico. Frontiers in Marine Science 1, article 8: 1-18.

https://doi.org/10.3389/fmars.2014.00008

Sørensen M.V. \& Pardos F. 2020. Kinorhyncha. In: Schmidt-Rhaesa A. (ed.) Guide to the Identification of Marine Meiofauna: 391-414. Dr Friedrich Pfeil, Munich.

Sørensen M.V., Jørgensen A. \& Boesgaard T.M. 2000. A new Echinoderes (Kinorhyncha: Cyclorhagida) from a submarine cave in New South Wales, Australia. Cahiers de Biologie marine 41: 167-179.

Sørensen M.V., Heiner I. \& Ziemer O. 2005. A new species of Echinoderes from Florida (Kinorhyncha: Cyclorhagida). Proceedings of the Biological Society of Washington 118: 499-508. Available from https://repository.si.edu/handle/10088/3634?show=full [accessed 27 Nov. 2020].

Sørensen M.V., Rho H.S., Min W., Kim D. \& Chang CY. 2012. An exploration of Echinoderes (Kinorhyncha: Cyclorhagida) in Korean and neighboring waters, with the description of four new species and a redescription of E. tchefouensis Lou, 1934. Zootaxa 3368: 161-196.

https://doi.org/10.11646/zootaxa.3368.1.8

Sørensen M.V., Rho H.S., Min W., Kim D. \& Chang CY. 2013. Occurrence of the newly described kinorhynch genus Meristoderes (Cyclorhagida: Echinoderidae) in Korea, with the description of four new species. Helgoland Marine Research 67: 291-319. https://doi.org/10.1007/s10152-012-0323-2

Sørensen M.V., Herranz M. \& Landers S.C. 2016. A new species of Echinoderes (Kinorhyncha: Cyclorhagida) from the Gulf of Mexico, with a redescription Echinoderes bookhouti Higgins, 1964. Zoologischer Anzeiger 265: 48-68. https://doi.org/10.1016/j.jcz.2016.04.004

Sørensen M.V., Rohal M. \& Thistle D. 2018. Deep-sea Echinoderidae (Kinorhyncha: Cyclorhagida) from the Northwest Pacific. European Journal of Taxonomy 456: 1-75. https://doi.org/10.5852/ejt.2018.456

Thormar J. \& Sørensen M.V. 2010. Two new species of Echinoderes (Kinorhyncha: Cyclorhagida) from the Solomon Islands. Meiofauna Marina 18: 67-96.

Ürkmez D., Pardos F., Sezgin M., Karaçuha M.E. \& Öksüz I. 2016. Echinoderes dujardinii Claparède, 1863 (Kinorhyncha, Cyclorhagida): a new record for the kinorhynch fauna of Turkey. Ecologica Montenegrina 6: 1-8.

Varney R.M., Funch P., Kocot K.M. \& Sørensen M.V. 2019. A new species of Echinoderes (Cyclorhagida: Echinoderidae) from the San Juan Islands, Washington State, USA, and insights into the kinorhynch transcriptome. Zoologischer Anzeiger 828: 52-63. https://doi.org/10.1016/j.jcz.2019.06.003

Yamasaki H. 2016. Two new Echinoderes species (Echinoderidae, Cyclorhagida, Kinorhyncha) from Nha Trang, Vietnam. Zoological Studies 55: e32. https://doi.org/10.6620/ZS.2016.55-32

Yamasaki H. 2017. Chapter 21. Diversity of Kinorhyncha in Japan and phylogenetic relationships of the phylum. In: Motokawa M. \& Kajihara H. (eds) Species Diversity of Animals in Japan. Diversity and Commonality in Animals: 543-563. Springer, Tokyo. https://doi.org/10.1007/978-4-431-56432-4_21 
Yamasaki H. \& Dal Zotto M. 2019. Investigation of echinoderid kinorhynchs described 90 years ago: redescription of Echinoderes capitatus (Zelinka, 1928) and Echinoderes ferrugineus Zelinka, 1928. Zoologischer Anzeiger 282: 189-205. https://doi.org/10.1016/j.jcz.2019.05.013

Yamasaki H. \& Durucan F. 2018. Echinoderes antalyaensis sp. nov. (Cyclorhagida: Kinorhyncha) from Antalya, Turkey, Levantine Sea, Eastern Mediterranean Sea. Species Diversity 23: 193-207. https://doi.org/10.12782/specdiv.23.193

Yamasaki H. \& Fujimoto S. 2014. Two new species in the Echinoderes coulli group (Echinoderidae, Cyclorhagida, Kinorhyncha) from the Ryukyu Islands, Japan. ZooKeys 382: 27-52. https://doi.org/10.3897/zookeys.382.6761

Yamasaki H. \& Kajihara H. 2012. A new brackish-water species of Echinoderes (Kinorhyncha: Cyclorhagida) from the Seto Inland Sea, Japan. Species Diversity 17: 109-118.

https://doi.org/10.12782/sd.17.1.109

Yamasaki H., Hiruta S.F., Kajihara H. \& Dick M.H. 2014. Two kinorhynch species (Cyclorhagida, Echinoderidae, Echinoderes) show different distribution patterns across Tsugaru Strait, Northern Japan. Zoological Science 31: 421-429. https://doi.org/10.2108/zs140011

Yamasaki H., Neuhaus B. \& George K.H. 2018a. New species of Echinoderes (Kinorhyncha: Cyclorhagida) from Mediterranean Seamounts and from the deep-sea floor in the Northeast Atlantic Ocean, including notes on two undescribed species. Zootaxa 4378: 541-566.

https://doi.org/10.11646/zootaxa.4387.3.8

Yamasaki H., Neuhaus B. \& George K.H. 2018b. Echinoderidae (Cyclorhagida: Kinorhyncha) from two seamounts and the adjacent deep-sea floor in the Northeast Atlantic Ocean, including descriptions of three new species. Cahiers de Biologie marine 59: 79-106.

Yamasaki H., Neuhaus B. \& George K.H. 2019. Echinoderid mud dragons (Cyclorhagida: Kinorhyncha) from Senghor Seamount (NE Atlantic Ocean) including general discussion of faunistic characters and distribution patterns of seamount kinorhynchs. Zoologischer Anzeiger 282: 64-87.

https://doi.org/10.1016/j.jcz.2019.05.018

Yamasaki H., Herranz M. \& Sørensen M.V. 2020a. An interactive identification key to species of Echinoderidae (Kinorhyncha). Zoologischer Anzeiger 287: 14-16.

https://doi.org/10.1016/j.jcz.2020.05.002

Yamasaki H., Fujimoto S. \& Tanaka H. 2020b. Three new meiobenthic species from a submarine cave in Japan: Echinoderes gama, E. kajiharai and E. uozumii (Cyclorhagida: Kinorhyncha). Journal of the Marine Biological Association of the United Kingdom 100: 537-558. https://doi.org/10.1017/S0025315420000429

Yildiz N.Ö., Sørensen M.V. \& Karaytuğ S. 2016. A new species of Cephalorhyncha Adrianov, 1999 (Kinorhyncha: Cyclorhagida) from the Aegean Coast of Turkey. Helgoland Marine Research 70: 24. https://doi.org/10.1186/s10152-016-0476-5

Zelinka C. 1913. Der Echinoderen der Deutschen Südpolar-Expedition 1901-1903. In: von Drygalski E. (ed.) Deutsche Südpolar-Expedition, 1901-1903, im Auftrage des Reichsamtes des Innern 14 (3): 417 436. Reimer, Berlin.

Zelinka C. 1928. Monographie der Echinodera. Wilhelm Engelmann, Leipzig.

Manuscript received: 14 July 2020

Manuscript accepted: 28 September 2020 
Published on: 30 December 2020

Topic editor: Rudy Jocqué

Desk editor: Pepe Fernández

Printed versions of all papers are also deposited in the libraries of the institutes that are members of the EJT consortium: Muséum national d'histoire naturelle, Paris, France; Meise Botanic Garden, Belgium; Royal Museum for Central Africa, Tervuren, Belgium; Royal Belgian Institute of Natural Sciences, Brussels, Belgium; Natural History Museum of Denmark, Copenhagen, Denmark; Naturalis Biodiversity Center, Leiden, the Netherlands; Museo Nacional de Ciencias Naturales-CSIC, Madrid, Spain; Real Jardín Botánico de Madrid CSIC, Spain; Zoological Research Museum Alexander Koenig, Bonn, Germany; National Museum, Prague, Czech Republic. 